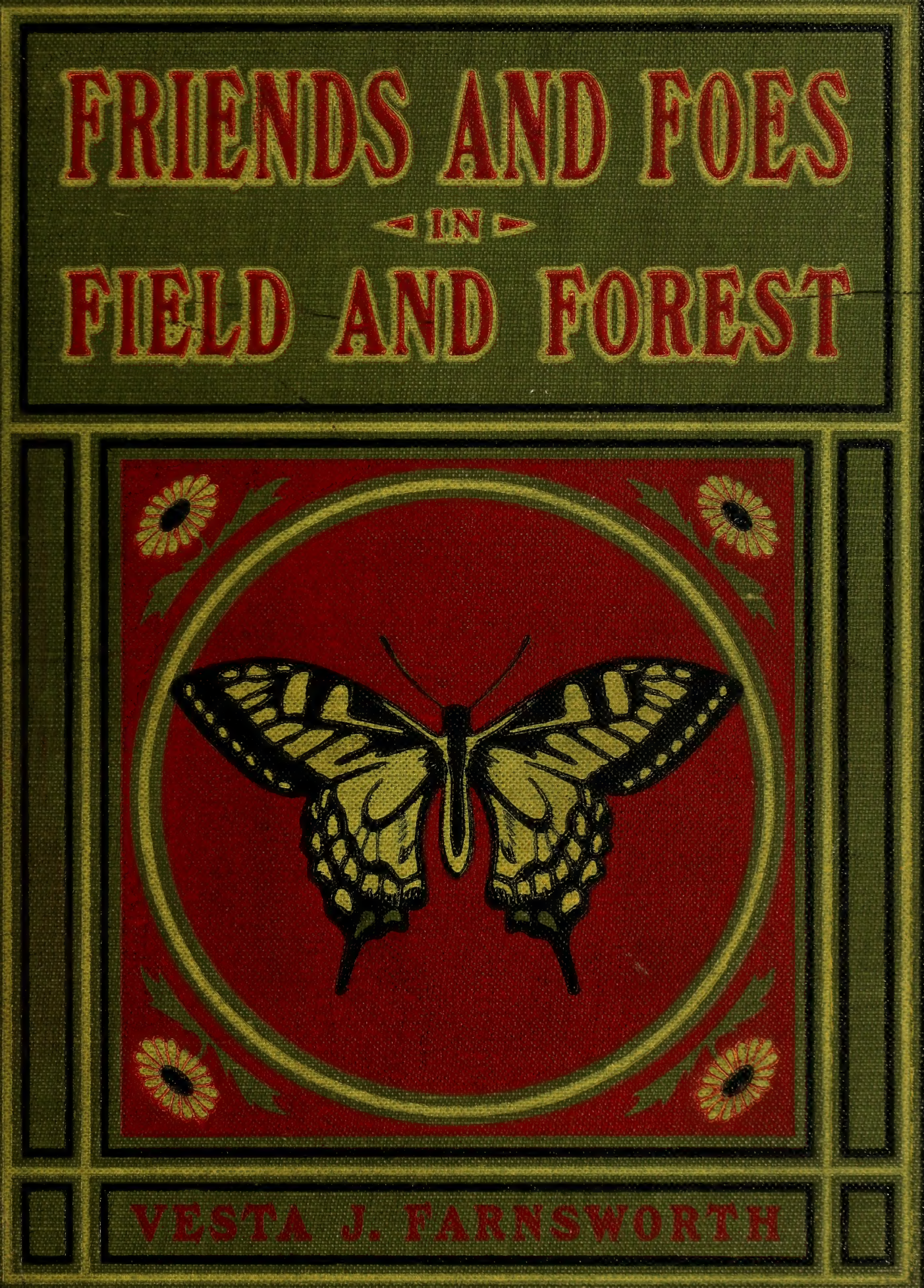



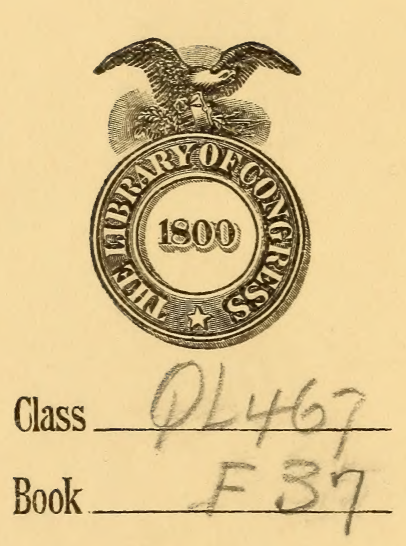

Copyrighth $\mathrm{N}^{0}$.

COPYRIGHT DEPOST. 
- 
Friends and Foes in Field and Forest 


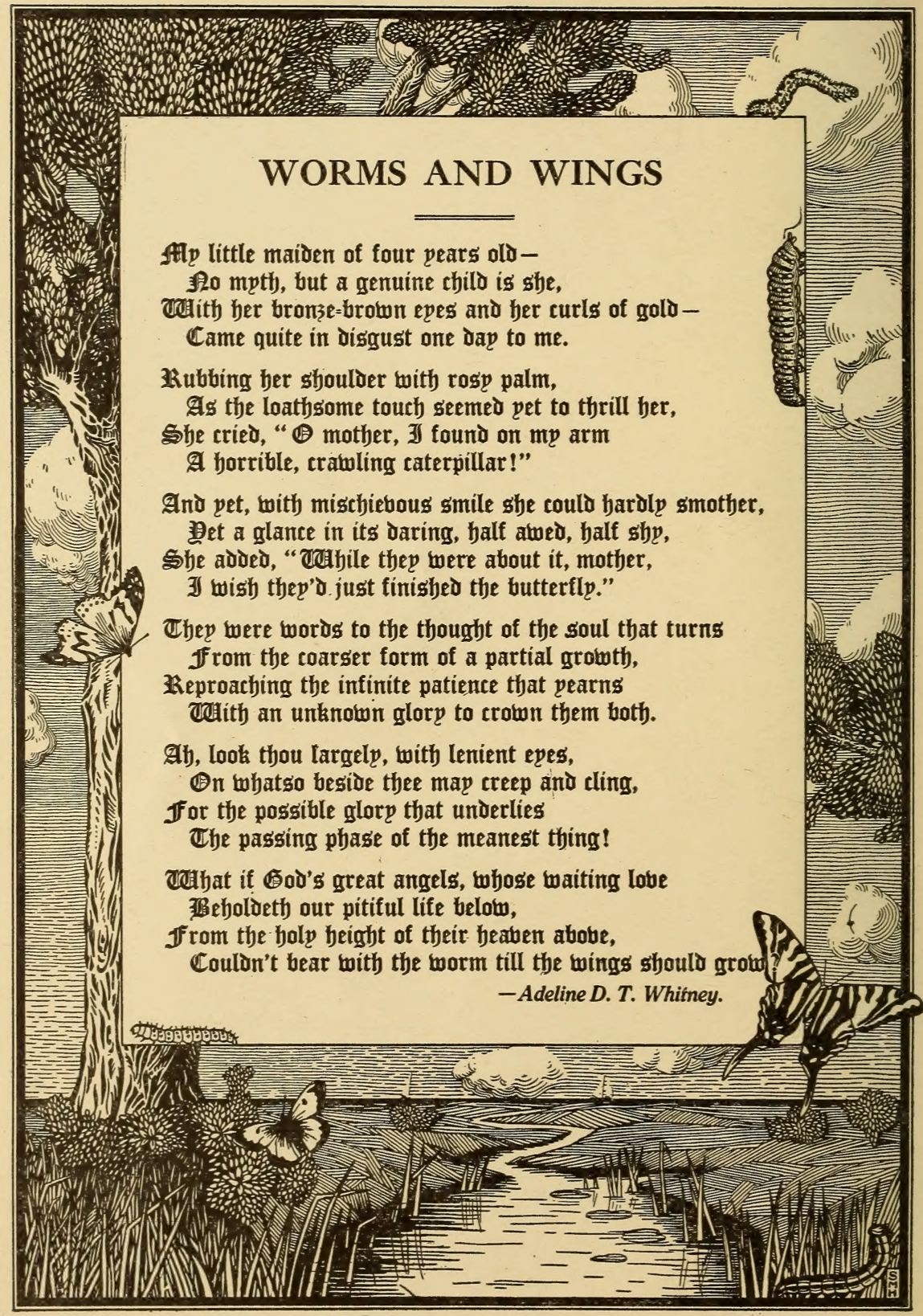




\title{
FRIENDS AND FOES
}

\section{In Field and Forest}

\author{
A Book for Home Reading, Intended to Assist \\ Mothers and Teachers in Interesting Their \\ Children in Nature Study, and to \\ Lead Their Minds Upward \\ to Nature's God
}

\author{
$\overline{\overline{ }}$ \\ Vesta J. Farnsworth \\ $\overline{\overline{ }}$

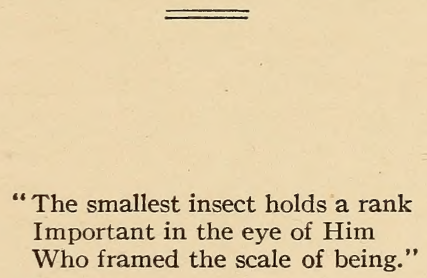

REVIEW \& HERALD PUBLISHING ASSOCIATION WASHINGTON, D. C.

South Bend, Ind.

New York City. 


$$
Q<+361
$$

Copyright, 1913, by

Review \& Herald Publishing Association Washington, D. C.

(C) CI.A358335 


\section{Contents}

Hemiptera -

A Bonny Boatman - A Noisy Insect

Diptera -

The Common Fly - Bottle of Blue - A Bold Burglar

HYMENOPTERA

Bees - The First Paper-Makers - Bonny Bombus -

Little, but "Exceeding Wise"-The Farmer-Ants -

Baby in the Tree Top

Orthoptera

The Grasshopper - Crickets - A Little Hypocrite 


\section{The Boy That Never Sees}

God help the boy that never sees The butterflies, the birds, the bees, Nor hears the music of the breeze When zephyrs soft are blowing;

Who can not in sweet comfort lie Where clover blooms are thick and high, And hear the gentle murmur nigh Of brooklets softly flowing.

God help the boy who does not know Where all the woodland berries grow; Who never sees the forest's glow When leaves are red and yellow;

Whose childish feet can never stray Where nature doth her charms displayFor such a helpless boy, I say, God help the little fellow. 
"For the first eight or ten years of a child's life the field or garden is the best schoolroom, the mother the best teacher, nature the best lesson book."

"With leaf and flower and tree, and with every living creature, from the leviathan of the waters to the mote in the sunbeam, the dwellers in Eden held converse, gathering from each the secrets of its life."

"Teach the children to see Christ in nature. Take them out into the open air, under the noble trees, into the garden; and in all the wonderful works of creation teach them to see an expression of his love." "Education."

"If you speak of a fly, a gnat, or a bee," says Basil, "your conversation will be a sort of demonstration of His power whose hand formed them; for the wisdom of the workman is commonly perceived in that which is of little size. He who has stretched out the heavens, and dug up the bottom of the sea, is also he who has pierced a passage through the sting of the bee for the injection of its poison." 



\section{HEMIPTERA}

\section{A Bonny Boatman}

Boatman: Do you see my oars sticking straight out from the back part of my body?

Glenn: I should call them legs instead of oars.

Boatman: They serve me as both. I am called the Water Boatman, though my proper name is No-to-nec'ta glau'ca. My first name means one who swims on his back. I live in the water.

Glenn: I see your body is shaped almost like a boat. Please tell us more about yourself.

Boatman: I was born in water - hatched from an egg my mother placed a water-plant. as all other inthe two long ones belike a pair of oars. fingers at the end. These fingers enable me to push myself through the water at very great speed.

Harold: Do you row about under the water?

Boatman: To be sure. I can fly and also swim.

Glenn: Do you have wings as well as oars?

Boatman: Yes, four of them, and cases to put them in. When tired of rowing, I open my wing-cases half-way, push out my wings, and sit on top of the water by the hour.

Harold: But you can not fly in the water. How do you get out of it when lying there on your back?

Boatman: I go down deep, make several quick strokes with my oars, which bring me up into the air, then I spread my wings and fly away. 
Glenn: How can you breathe under water?

Boatman: I have little openings called spiracles in the sides of my body. When I come to the top of the water, air gets in beneath my wing-cases, and enters the air-tubes. I am obliged to come often for air. If some wise man could invent a boat that would be able to propel itself under water, and then come out and be a flying-machine, he would be called a great man. I am like both of these, and am not great at all.

Harold: But you did not make yourself, and your Creator is greater and wiser than all men.

Boatman: True, and he has made a variety of insects.

Glenn: What is an insect?

Boatman: Your mother can tell you. I have a sharp beak, which hurts like the sting of a wasp. With it I suck the juice from a water-mite, and then throw its skin away. There is one coming now. I shall have it for my dinner.

\section{FOUR LIVES IN ONE}

Harold: Did you see the Water Boatman, mother, and hear his story? He said you could tell us something about insects. Will you please do so now?

Mother: The word insect means cut into. All true insects have three parts to their bodies, - the head, the thorax or chest, and the abdomen or body. An insect, too, has three pairs of legs, six in all; and nearly all insects have two or four wings. Most insects pass through

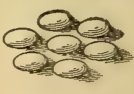

EGGS four changes during their lives: First, they are hatched from eggs; second, they become larvæ.

Harold: What are larvæ?

Mother: Larva means masked, or concealed,- - that is, you would not know by looking at the larva whether it was going to be a beetle or a butterfly. After the larvæ change their skins several times, they are called pupæ. 
Harold: What does that mean?

Mother: It means a baby or doll. A man named Linnæus

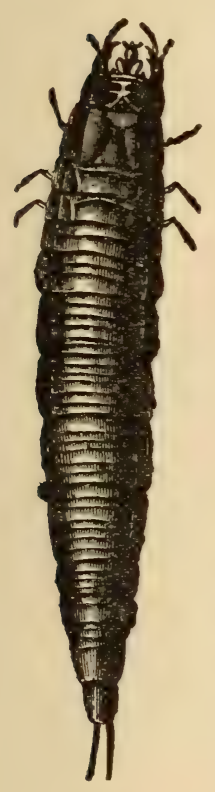
gave them this name, because he thought that insects while in this state looked like a baby wrapped in tight bands.

Glenn: Then that was what I saw the other day, - a little gray case like a coffin, and I could see the head, feet, wings, and all wrapped up in it, like a mummy. Its outside case was so pretty. It was marked with black rings, and had little golden dots in different places. But I thought the little creature inside was dead.

Mother: It was only sleeping, and probably if you had kept it a few days, a gay butterfly would have come out. While in the pupa state some insects take no food, others have a supply in their pupa-case. Many do not move at all, and seem to be dead, while others eat, grow, and move about LARVA inside their narrow home. At last the pupa becomes an imago, or perfect insect. The word imago means that the insect is the image of its parent. Now do you remember the four changes an insect passes through during life?

Harold: First, it is hatched from an egg; second, it becomes larva; third, pupa; fourth, it is known as an imago.

Mother: Besides these four changes, an insect is really changing all the time. When a caterpillar is hatched, it begins to eat, and perhaps makes its first dinner of the egg-shell from which it came.

Glenn: Is a caterpillar larva, mother? Mother: Yes. An insect while in the larval

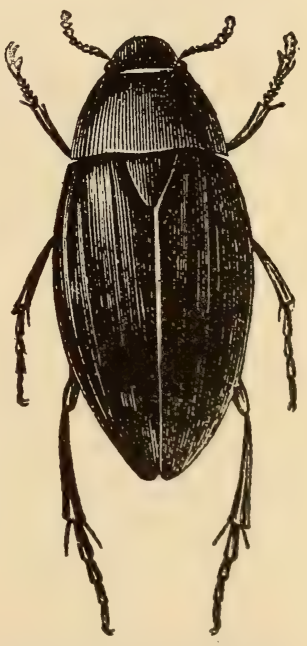

THE IMAGO, OR PERFECT INSECT 
condition eats a great amount of food. It grows so fast it outgrows its skin as you outgrow your clothes. Finally the skin bursts open, and it crawls out in a bright new suit. Strangest of all, and yet true, it not only changes its outside skin, but the skin of its mouth, stomach, and all its inside organs comes off with the outside skin. This is called molting.

Harold: We say chickens molt when their feathers come " off, but insects do not have feathers.

Mother: Many of them do. When seen through a microscope they have bright colors, and are decked in gay plumage.

Glenn: What do insects eat?

Mother: Everything you can think of, whether animal or vegetable. Many prey on other insects, and some suck blood from animals. Every plant furnishes them food. The common nettle feeds thirty different kinds of insects, and two hundred feed on cabbage, and other insects that have already eaten it. They eat wood, leaves, roots, flowers, fruit, honey, cheese, clothes, furs, animals, - in fact, almost any substance that can be named.

\section{A LARGE FAMILY}

Glenn: How many kinds of insects are there?

Mother: Thousands; I don't know how many; I don't think any one ever counted them.

Harold: Do they all belong to one family?

Mother: They are divided into several general classes,

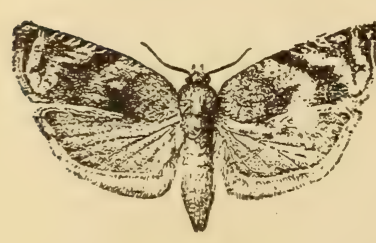

BUTTERFLY or families. Each one of the family names ends with the Greek word ptera, which means wings. The first part of the family name tells something about the wings of the insect that bears the name. The first great family is called Dip'te-ra, which means two wings. Flies, mosquitoes, and gnats belong to this family. The second family is called 


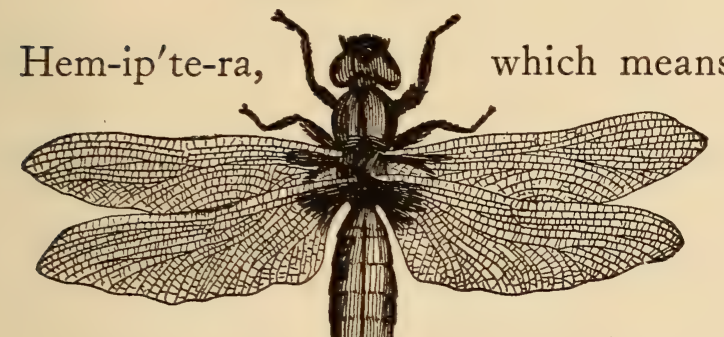

Mother: The which means are moths and ${ }_{\text {FLA }}$ butterflies. They are called Lep-i-dop'te-ra because ${ }^{\text {FLY }}$ they have scales on their wings.

Harold: Not scales like a fish?

Mother: They overlap just the same, but you will learn more about that another time. The fourth class of insects is called Or-thop'te-ra, meaning straight wings. In this family we find cockroaches, crickets, grasshoppers, and others. The fifth family has a rather long name, Hy-men-op'te-ra. It means

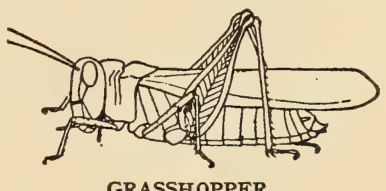

GRASSHOPPER membrane wings. To this family belong bees, wasps, and ants.

Harold: Ants do not have wings.

Mother: Later on we shall learn whether they do or not. The sixth family is called Neu-rop'te-ra, that is nerve wings. Dragon-flies, May-flies, and others belong to the Neu-rop'te-ra family. The seventh is called Col-e-op'te-ra, meaning sheath wings. To that family belong the beetles. You know that there are five races of men, which are known as white, yellow, brown, red, and black. These are divided into a great number of smaller families, as are also insects.

Harold: To what family do spi-

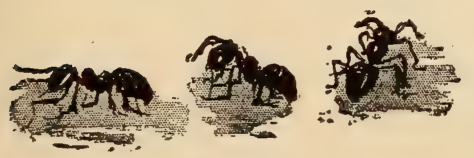

ANTS ders, worms, and other creeping, c r a w ling things belong?

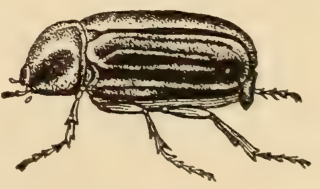

BEETLE 
Mother: They can not properly be called insects; for we have learned that insects have three parts to their bodies, three pairs of legs, and that they nearly always have wings. When you look at a worm or spider, see if it

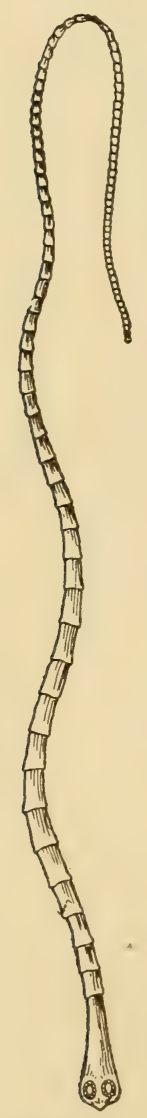
has all these.

Glenn: What are the things that stick out from the heads of insects?

Mother: They are their horns, or antennæ. They are not just like horns, for they have joints so they can be moved in any direction. It is supposed that with them an insect feels, hears, and smells, though their use is not fully known.

Harold: Can insects see?

Mother: Try to put your hand on a fly, and you will find out. Many insects have what are called compound eyes, that is, many eyes in one; and sometimes one compound eye has many thousands of single eyes, or facets,

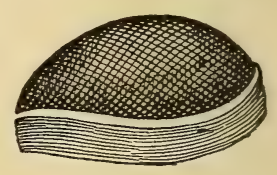

COMPOUND EYE as they are called. Here is a picture of one. Glenn: It looks like the seeds of a ripe sunflower. How evenly they are set together!

Mother: Yes, it is truly wonderful. I once looked at the eye of a fly through the microscope, and when I saw God's work in making the eyes of such a common insect, I felt like falling on my knees in prayer. The more closely we examine even the smallest thing WORM IS NOT he has made, the more we shall see that will inspire AN INSECT love for him. Did you know that God has given to the insects tools with which they get their living, build their houses, and do many wonderful things?

Glenn: What kind of tools?

Mother: They have saws, augers, spades, pumps, scissors, 
knives, swords, and spinning-machines. Men are proud of the high buildings they erect; but they would build houses nearly a mile high if made as lofty as the ants' in proportion to their height. A flea, an eighth of an inch long, can jump a yard. A man ought to jump about half a mile at a single bound to equal a flea.

Glenn: If we could jump like fleas, we should go through the air faster than an express-train.

Mother: Yes, and compared with men, if size is taken into account, insects excel them in other things. This morning I saw an ant carry a dead fly two or three times larger than itself up a straight wall. What should you think of a man who could walk upright like that carrying a heavy weight? But the ant did it without difficulty.

\section{A Noisy Insect}

Harold: What little wonders insects are! To what family does the Boatman who told us his story belong?

Mother: To the Hem-ip'te-ra family.

Glenn: What other insects belong to his family?

Mother: The cicada (si-ka'da) is one. It lives in southern Europe, Africa, in parts of America, and in the islands of the sea. It loves to stay on the branches of trees when the sun shines hot. Sometimes large grasshoppers are mistaken for it. I see one on the branch of that tree. Keep quiet, and we shall let it talk to you.

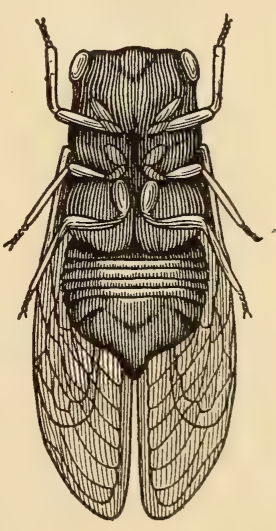

MALE CICADA

Glenn: How do you do, Mr. Cicada? Some people think that you look like a grasshopper, but I do not think that you are like them. 
Cicada: Look at my picture, and you will say I am not at all like a grasshopper. You will notice that I have no long hind legs. My body is thick and heavy, my head is broad, and four gauzy wings cover my back. I have three very large eyes set like this $\therefore$ in my forehead, and short antennæ, or horns.

Harold: Do you have thousands of eyes in each one of the three?

Cicada: No, they are not compound, but simple eyes like your own. Mrs. Cicada is one of the insects that carries an auger, and with it she makes holes in the bark of trees, where she lays her eggs.

Glenn: Is the auger in her head?

Cicada: It is in the back part of her body. When not in use it lies in a little groove made to receive it. The auger has three parts; one is so strong and sharp that when she sticks it into a tree it keeps her from falling while at work; the other two have teeth like a saw, which move up and down. She can bore deep holes in the wood. I sing all the time she is at work. I have a very strong voice. Some people seem to think it not very musical, but it sounds good to me. The Greeks loved our song so well they shut us up in wickerwork cages that they might hear our joyous Cree, cree, cree, rapidly repeated. When you sing you use your throat, but my song is produced by organs on the under side of my body. I have two horny plates which cover two deep cells, and in the bottom of each cell is found what looks like a tiny mirror. It is really membrane, but shines like brightest glass, and in it can be seen all the colors of the rainbow. These cells are like two little windows through which you can look into my body.

Glenn: What makes the noise?

Cicada: In the cells I have told you about are two little drums. In my back there are two strong muscles which move 
these drums quickly backward and forward, and that makes the sound. You would not expect a boy with two drums to be very quiet, and no more can I be.

Glenn: What do you eat?

Cicada: We suck the sap of trees.

Glenn: Do your children change to larvæ and pupæ when they hatch from the eggs in their tree nest?

Cicada: Certainly. The larvæ are small and white at first. They leave their nest, crawl down the tree trunk, eat its roots, and keep growing. They remain in the pupa state all winter, and in the spring crawl out of the ground, hook themselves on to the tree, and then crawl out of their pupa-case, or skin. They leave their skins where they came out of them. The larvæ are very weak at first, but the warm sun strengthens them, and they soon join the Cree, cree, cree chorus. You would not find it easy to catch one of us, for we are easily frightened, and fly away at the slightest sound.

\section{FROGGIE FROTH}

Iva: Where did the froth on these leaves come from? It looks as if made of tiny bubbles.

Froggie Froth: Allow me to introduce myself. My proper name is Aph-roph'o-ra, which means, the foam I carry. I am also called Froghopper and Frog-spit; when I am full grown, I jump like a frog. You may call me Froggie Froth if you

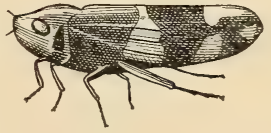
like. Here is a picture of one of my brothers, but it is about ten times as big as he was.

Iva: Are you a perfect insect now?

Froggie Froth: No; I am in my larval state. Soon I shall change to pupa, and after that shall look like the picture.

Glenn: Where does all this froth come from?

Froggie Froth: I made it; it is the house in which I live, 
and is made of little bubbles. I have a very delicate green skin, which must be kept moist, so I climb on the stalk of some plant and suck its juice. Then I place myself on a leaf, and keep moving my body. Soon a little bubble comes out, then another, and another till I am all covered up in my bubble house.

Glenn: Do the bubbles last?

Froggie Froth: For a while, and I keep making more to take the place of those that melt away; otherwise my body would soon dry up and I should die, just as a fish does when taken out of water. My bubble house protects me from the air and heat as I am now, but when I am ready to change from larva to pupa I can make part of the bubbles dry up so there will be a little dry room inside in which the change is made. This takes place in September. My skin splits open along my head and chest. I leave my bubble mansion, and have a pair of wings. My sisters move slowly about, but my brothers are champion jumpers. Though so small, they can leap more than six feet. For this reason they are sometimes called flea grasshoppers.

\section{A GREAT ATHLETE}

Glenn: There you go, hop, hop, hop! What is your name,

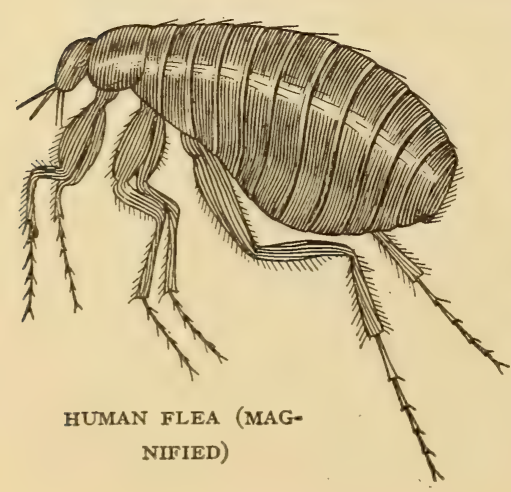
please?

Flea: My proper name is $\mathrm{Pu}^{\prime} \mathrm{lex}$ ir'ri-tans, but I am known as the flea. This is my photograph, but the picture made me many times larger than I really am. How fa. can you jump?

Glenn: O, a long way; six or seven feet, I think!

Flea: As little as I am, I can 
jump half that distance myself. If I were as big as you, I believe I could jump a mile. That is the way I keep alive, for you folks seem to take special delight in killing me.

Hazel: But you bite us, Mrs. Pulex. See that big blotch on my wrist where you bit me a minute ago!

Flea: If you had two long, sharp knives with saw-like edges, and should stick them into things, I am sure it would show more than that.

Iva: Do you have two knives?

Flea: Yes; and they are kept in a little covered case, or tube, so they will not get broken. I can eat a lot of blood for one of my size, and I need sharp tools to get it with. Baron Walckenaer, in the "Natural History of Insects," says that in Paris he saw what were called the learned fleas. Thirty of them went through exercises like soldiers, standing on their hind legs, and carrying small splints of wood. Two fleas were harnessed to a golden carriage having four wheels. A third flea was seated in the carriage and acted as coachman, holding a splinter of wood for a whip. Two other fleas drew a tiny cannon on its carriage. These and other wonders were performed on polished glass. The fleas that acted the part of horses wore a gold chain fastened to their hind legs, which was never taken off. When seen by Baron Walckenaer, they had lived thus for two and a half years, and not one had died.

Iva: Fleas are so small I don't see how people could see them performing as you say.

Flea: Those who came to see the fleas looked through magnifying-glasses, so you will know that the golden carriage and other things drawn by them were smaller than anything you can think of.

Harold: What did they have to eat?

Flea: They were placed on a man's arm and sucked his blood. When they became lazy and did not wish to work, the 
man took a burning coal and moved it about near them; that woke them up in a short time, and they began to perform.

Glenn: Where do you live?

Flea: We are found in nearly all countries, and thrive best among dirty people. Our eggs are laid in the cracks of floors and in old rubbish.

Hazel: Are there any other kinds of fleas?

Flea: Yes; there are cat fleas, dog fleas, and those that live on pigeons and poultry.

\section{SWEET SUMMER-TIME}

THE wonder season of the year,

Sweet summer, comes again,

When everywhere, afar and near,

In every field and glen,
The dewy mornings gaily call

In bird-notes sweet and strong,

Come forth to labor, one and all;

The noontide comes erelong,

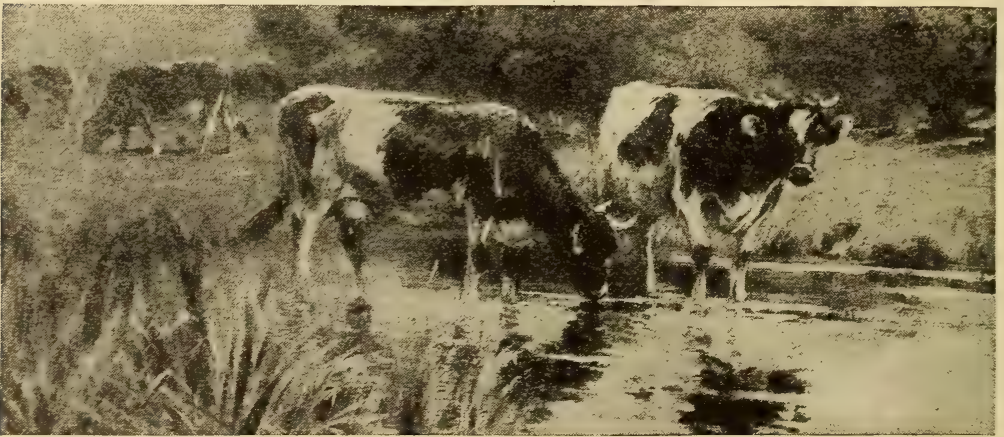

The happy insects, birds, and bees, The waving grass and nodding trees, The rolling fields and wayside nook, The hazy hills and babbling brook, Are filled with life and song.
When shepherds seek the meadow-land, And in the stream the cattle stand, When through the drowsy afternoon All nature calls with soothing croon, "O, rest with me and grow!" 


\section{DO YOU S'POSE?}

Do you s'pose little flies, with their thousands of eyes, When their mama is busy with tea,

Ever climb on the chairs and get in her way, dnd cry, "Lemme see! Lemme see!"

Do you s'pose little fish, when their mamas wish To take a short nap,- - just a wink,Ever pound on the door with their soft little fins, And whimper, "Please gi"me a d'ink"?

Do you s'pose little bees, as they hum in the trees, And find where the honey-sweets lurk, Ever ask of their papa, who's busy near by, "I know-but what for must I work?"

Do you s'pose, do you s'pose that any one knows Of a small boy who might think awhile Of all this and more? You do? So I thought, And now let us see if he'll smile. 


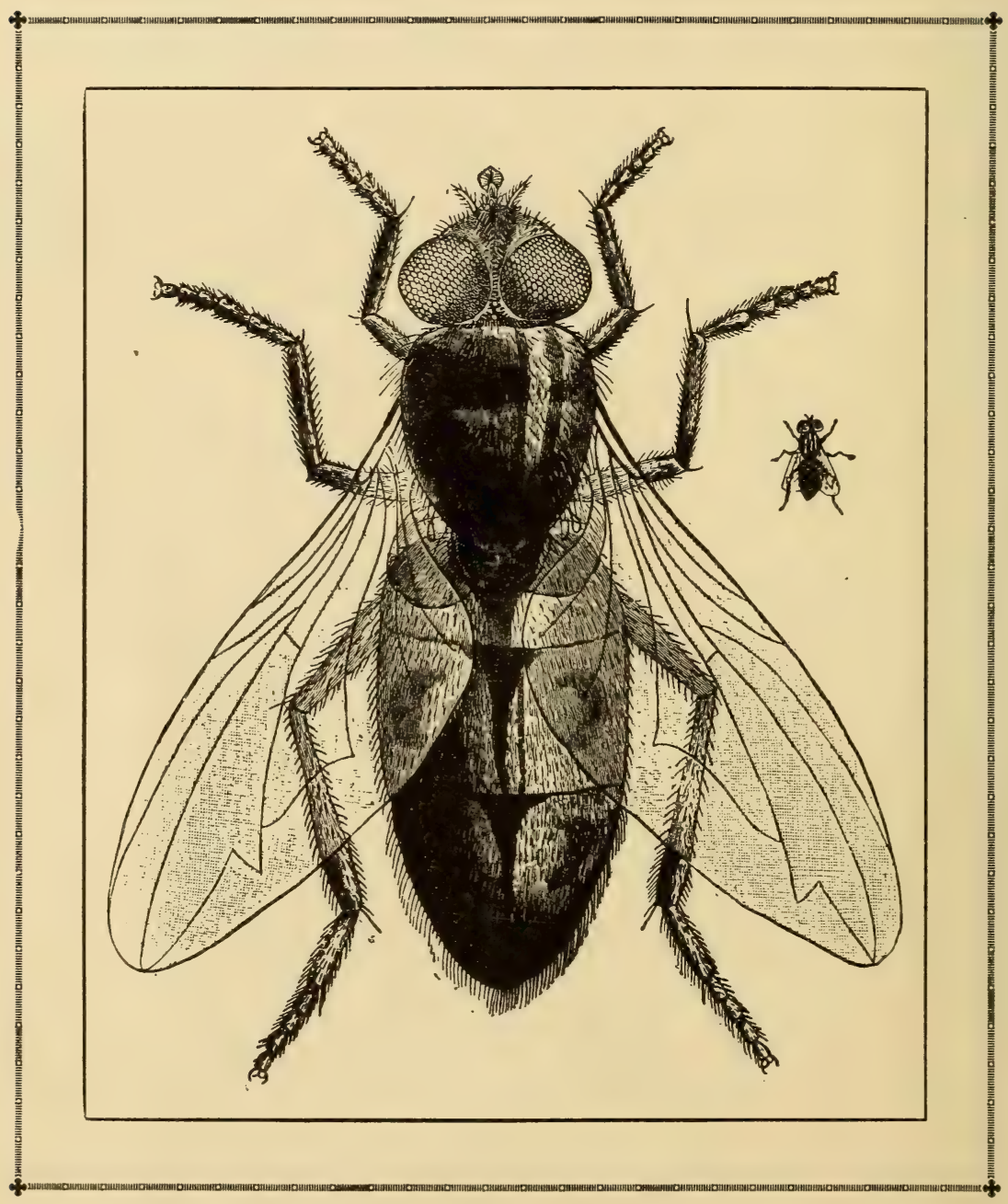




\section{DIPTERA}

\section{The Common Fly}

Harold: Here you are, Mr. Fly. Now please talk to us, as Water Boatman and Froggie Froth did.

Fly: What do you want me to tell?

Glenn: How you can walk up and down that window-pane without falling.

Fly: I have little suckers on my feet, which hold me, so I can run about with my head down as well as any other way.

Glenn: How old are you?

Fly: One month to-day.

Harold: Only a month? Why, you are as big as you will ever be. Did you look at first as you do now?

Fly: O, no! I was hatched from a tiny egg laid by my fly mother. At first I was a little grub, or worm, about one third of an inch long. I had rings around my body, and on the rings were hooks. I kept eating all I could, and so grew. My skin got hard in about a week, and it made a very nice little pupa-case like a barrel-shaped coffin. Had you seen me then, you might have thought I had no life. While in my little coffin my legs grew first, then my wings, after that my head, eyes, mouth, and my trunk, or tube. After two weeks I began to knock with my head. The end of my coffin flew open, and I turned from a worm into a wonder. I stood awhile in the bright sunshine; for I felt cold and weak. I kept shaking my wings till they were dry. All the wrinkles came out, and I began to fly about just as I do now, looking for something to eat.

Glenn: But I don't understand yet how you can walk on the ceiling without falling. 


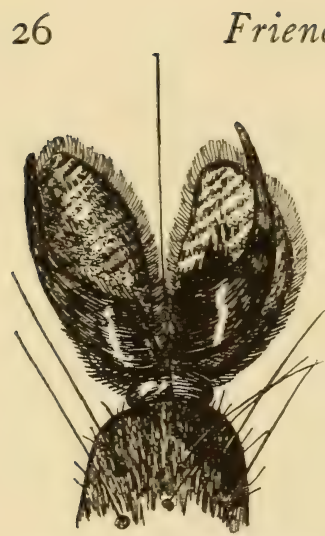

Fly: There are two claws on each of my feet, and under each is a tiny cushion. Some very wise men say there are twelve hundred hairs on each cushion, though how they found out I am sure I do not know. Each hair has a little knob on the end, and from these comes a sticky gum which holds me to the surface on which I am walking.

Harold: A little while ago I saw you FOOT OF FLY (MAGNIFIED) rubbing your legs over your body, and then twisting and rubbing them together. Why did you do that? Fly: I was combing my hair. My body is covered with short hairs, and those on my legs are stiff, so I can use them as a comb and brush. In this way I keep myself clean and neat.

Glenn: I think your wings are beautiful, but why

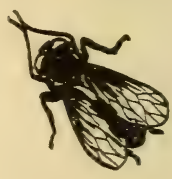
COMBING ITS HAIR don't you fold them up close to your body when not using them?

Fly: Because they were made to stand out straight. I have but two wings, while many insects have four.

Harold: How can you tell when we try to catch you?

Fly: I can see you with my eyes.

Iva: You must have eyes in the back of your head then.

Fly: Each of my eyes is made of thousands of little eyes, or facets, which enable me to see in all directions at once. When a sly boy or girl tries to creep up and catch me, I fly away. My eyes enable me to protect myself. Once a woman caught one of my brothers and looked at one of his eyes through a microscope. She said it was truly wonderful, and that it looked like a great half-ball set with the tiniest bright stones, all in the form of perfect little squares. I am told there are four thousand of these little facets, though I never counted them. When you think how small my eye really is, and yet 
how perfectly it is made, it should cause you to love the One who made you and me. I have heard that some insects have as many as twenty-five thousand eyes. You see it is the same as though we were in a room covered with mirrors; we can see all around us.

Hazel: What is that little tube with which you go about touching everything?

Fly: That serves me as a mouth, and for hands, and with it I can tell what is good to eat.

Harold: Will you tell us how you breathe?

Fly: There are several small openings in my body through which the air enters at each side.

Iva: Do you have bones?

Fly: No; my hard and horny skin serves me instead of bones. I believe that is the way all insects are made.

Glenn: What is your family name?

Fly: I belong to the Dip'te-ra family.

Harold: I don't see what good you do in the world.

Fly: All over the world animals are dying, and the bad odors from their bodies would cause much sickness among the people. We lay thousands of eggs in these dead bodies, which soon hatch, and the larvæ, or worms, eat the flesh from the bones, and they soon dry up. A man named Linnæus says that only three flies and their children could eat up a dead horse as quickly as could a lion.

Hazel: But you carry germs of sickness, and we shall put up wire screens to keep you out of the house. We shall also keep the premises clean so there will be but few flies.

Fly: Since you dislike me so much I am sure you would not care to have some of my relatives near you; such as, the bot-fly, which hurts cattle; the gad-fly, which troubles sheep; and the tsetse fly, which is so dangerous to domestic animals in Africa. 


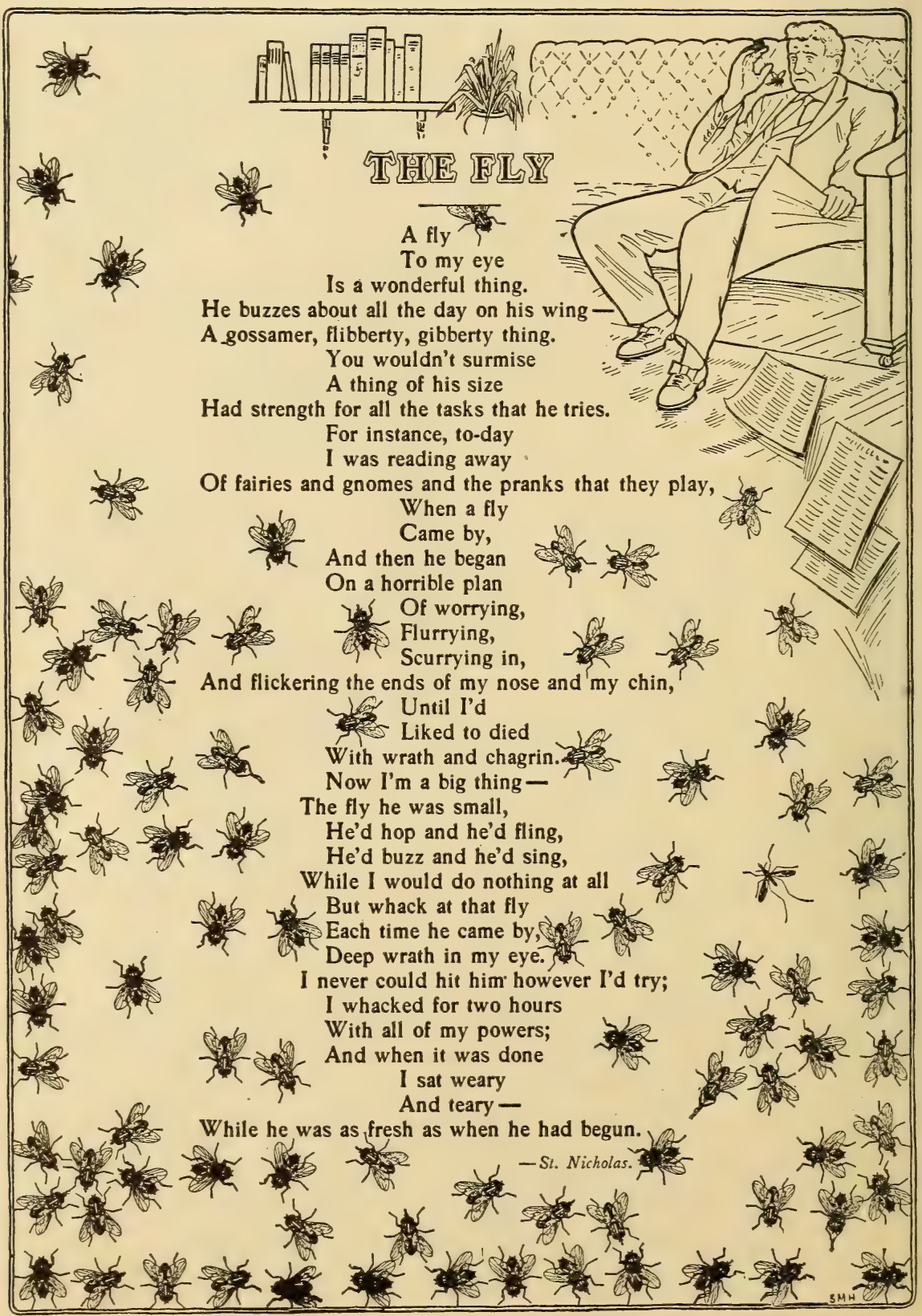




\section{Bottle of Blue}

Fly: Here comes my cousin Bluebottle. She will talk to you while I go to dinner.

Bluebottle: I am trying to find a pantry where there is some meat. I am known as the meat-fly, and blow-fly, as well as Bluebottle, because I always lay my eggs in meat, either cooked or raw, if I can find it. A slice of cooked beef or mutton is exactly to my taste, and I place my eggs on it in neat little packets, which are very much like the little asparagus bundles your mother buys, only the eggs are so very, very small.

Iva: What a strange place to lay your eggs!

Bluebottle: The meat furnishes both cradle and food for my children. In twenty-four hours after I leave the eggs, they hatch; then they are larvæ for a month, though I suppose you would call them worms. They are very hungry, and at once bury themselves in the meat and begin to eat.

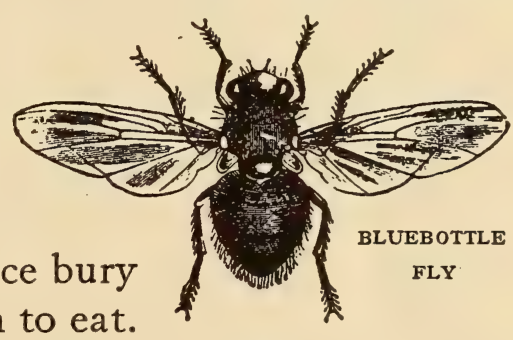

They grow very fast, and change their skin often, but do not cast off their last suit; it turns hard and yellow, then red, then black, and this forms their pupa-case, in which they take their long sleep before they become Bluebottles like myself. Before entering the pupa state they leave the meat, and go into the ground.

Harold: How do they get out of that little bottle, or pupacase?

Bluebottle: The pupa is covered with a thin skin, or sheath. Each leg, each wing, the body, and the head are wrapped separately, as your glove has a place for each finger of your hand. There it lies like a mummy in its wrappings all winter. When it wakes up, it makes an opening in its pupa-case. 
Iva: How does it do that?

Bluebottle: It comes out at the end where the head is. It is like two half-cups fitted together. Its head swells out and then gets small, swells out again, and keeps this up till smash goes one of the half-cups, then the other, and out comes the Bluebottle.

Harold: I have been looking at that strange trunk, or tube, you carry.

Bluebottle: I use it to suck liquids, and with it also eat solid things, like sugar. My trunk does not move, but my lips go up and down, round and round in every direction. I moisten sugar with water, which comes from my trunk when I wish it. If the sugar does not melt quickly enough, I work or knead it with my lips, and it soon becomes soft, so I can suck it through my tube.

Harold: When we have hard things to eat; we cut them with a knife.

Bluebottle: I am sure you do not carry a knife in your mouth all the time. That is what I do. A man named Réaumur took much time to study my trunk and mouth. He knew that many juices of which flies are fond, are covered up, as in fruit, and those flies that suck blood must pierce the skin. He thought in order to do these things we must have a sharp knife or lance; so he kept hunting for it, and at last found it in the upper part of the trunk, hid in a little groove, and covered in a small case.

Hazel: Are there any other kinds of flies that belong to the Dip'te-ra family?

Bluebottle: Hundreds of them. Here comes my friend Pegomyiœ, whom we call Peggy for short. She can tell you some very interesting things concerning herself and our other relatives, and I am sure she will be glad to do so if you will ask her. 


\section{OTHER FLIES}

Harold: Tell us, Peggy, how your larvæ become flies?

Peggy: Perhaps I ought to say, first, that my children are all miners. We are much smaller than Bluebottle, so I am sure you could never guess where we make our mines, and what for.

Iva: Do tell us, then.

Peggy: We dig them in leaves. We like sorrel or thistle leaves best. When my eggs hatch, the larvæ dig tunnels in the soft, pulpy part of the leaf. They are so small that you can not see them unless you hold the leaf between yourself and the light.

Hazel: What do they dig with?

Peggy: With a tiny hook fastened to the head. When their galleries are finished, the green part of the leaf is gone. They eat it for food. Think of making a home inside a leaf! Cousin Or'ta-lis eats cherries for breakfast, dinner, and supper. She is only one twelfth of an

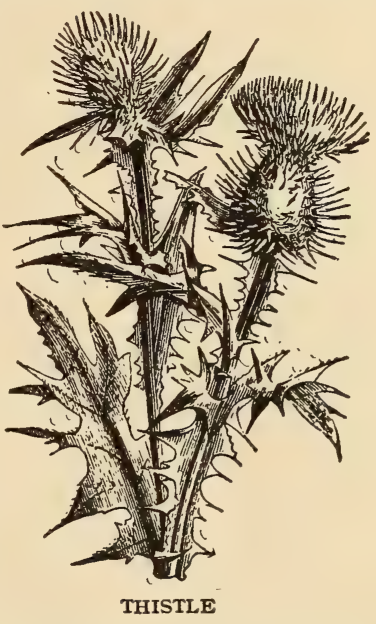
inch long, but you may find her babies eating the cherries you wanted yourself. Cousin $\mathrm{Da}^{\prime}$ cus is about half as large as the house-fly. She has very pretty wings,- gold, pink, and blue,

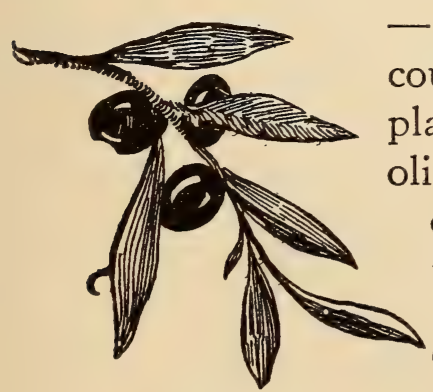

OLIVES
- and she jumps about as though she could not keep still a minute. She places her eggs under the skin of young olives when they are growing, putting only one egg in each olive. As she lays three or four hundred eggs in a season, she causes great loss to olive growers. The baby Dacus bores holes in the fruit; then you would not care to eat it. 
Glenn: Have you any more cousins or second cousins?

Peggy: Yes, many, many more. One of my cousins is noted for her large family. A Frenchman took special pains to study her habits, and he says she has twenty thousand children at one time. Each one wears a thin white dress. If meat is placed near them, they eat greedily. Have you ever seen in a field of wheat or rye some stalks bent downward as though beaten down by hail or trampled by cattle?

Harold: Yes, I saw some that way last year.

Peggy: If you had looked carefully above the lowest knot on the stem, or stalk, you would have found the larvæ of the Hessian fly hard at work. This fly was noticed first in North

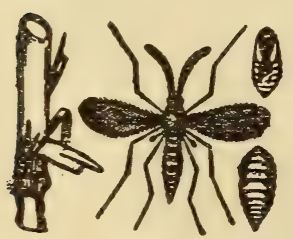

HESSIA N FLY ; PUPA, LARVA, WHEAT STALK SHOWING LARVA America during the war for independence, and many supposed that it was brought across the sea in the baggage of the Hessian troops. That gave it its name. This is its picture. On land it flies six feet at a time. In thirteen years it traveled two hundred miles from the sea. After this the people in England were badly frightened, for they thought the Hessian fly had been brought in grain from America to England. They appointed a great council to see what should be done. Was it not strange that so small an insect should raise such a commotion? But little things do cause a deal of trouble sometimes.

Harold: Are there no insects except flies in the Dip'te-ra family?

Peggy: Yes, many of them, but I think the flies number more than the others, for in one family of flies alone there are more than a thousand different kinds, so you see they can hardly be numbered. But here comes one of the Dip'te-ra family, singing as it flies, and it is not a fly either. But I shall let it tell you about itself. Farewell. 


\section{A Bold Burglar}

Harold: Do you belong to the Dip'te-ra family, Mr.:Mosquito?

Mosquito: So I am told; but I have been ill-treated all my life.

Glenn: But you stick your sharp lance into our skin, and steal our blood.

Mosquito: I? Never. Perhaps it is not polite to say it, but that is what my sisters do. I live only a little while, stay in the woods nearly all the time, and never touch a drop of blood.

Iva: Where did you come from?

Mosquito: My mother laid her eggs in a stagnant pool. They were glued fast together, and floated about like a little boat. When the eggs hatched, and we became larvæ, we dropped into the water, and there I had many a frolic with my brothers and sisters and neighbors. One day some children came to our pool and dipped up some of the water in their hands, and some of my brothers and sisters were caught. As the children looked at them they said, "See the wigglers." I suppose they gave us that name because, when we are in the water, our heads hang down, and we breathe through our long tails, which stick straight up. When we are frightened, we hurry, or wiggle, to the bottom of the water to get out of sight; but we soon have to come up again to get breath.

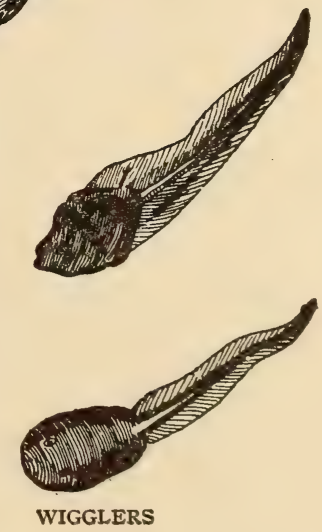


Iva: Please tell us, Mr. Mosquito, how you got your wings. I am sure you did not have any when you were in the water.

Mosquito: At last we got so sleepy after wiggling about a good while, that we all went fast asleep right on top of the water. One pleasant day I woke up and found that I was no longer a wiggler. I raised up my head, and found I had six long slim legs; but, best of all, I had a pair of wings, though I did not know how to use them. I felt weak and trembling, and sat very still in my little boat of dried-up skin till my wings were dry, and then I flew to a bush and began hunting for something to eat.

Glenn: Do you live in all parts of the world?

Mosquito: Nearly all, I believe. In India, Australia, the Pacific islands, and other warm countries, my sisters are such a pest that the people who live there are compelled to cover their beds with netting, or they could not sleep at all. Another thing that causes people to dislike our family is that we are said to carry diseases from one person to another, such as malaria and yellow fever. In some places we are killed while we are yet larvæ by pouring kerosene into the pools where we live.

Harold: Are there any mosquitoes larger than yourself?

Mosquito: O, yes! I am quite small compared with some of our family. There are the Striped Stockings, so called because they have black and white markings on their legs. They will outbuzz and outsting almost any number of mosquitoes the size of my sisters. A dozen of them in a room will cause the people to retreat in haste.

Hazel: I once read that mosquitoes light on the heads of tadpoles and young trout when they come to the surface of the water, and that their bite causes the fish to die and float downstream, and the tadpoles' tails become swollen and bleed.

Mosquito: I have never seen anything of that kind, though it is possible others have. 
Harold: I read a strange story by C. C. Abbott, who has spent much time studying many kinds of insects. He says:-

"I once witnessed a remarkable flight of mosquitoes. . . . The sky was clear, and while I was rowing slowly down the creek, suddenly, almost between winks, I saw a long, narrow line of dark gray cloud rising rapidly and extending over half the western horizon.

"In a few minutes I heard a faint, humming sound which grew louder and louder, and I thought of a tornado. I was too frightened to plan for my safety, and indeed there was no time in which to act. Heading for the shore, I reached an overhanging elm, and clinging to a projecting root, I waited the oncoming of the supposed tornado.

"It came, but not as wind. The tempest proved to be a cloud of mosquitoes. It rose higher and higher as it approached, and when directly overhead it quite cleared the tree tops. Nevertheless, it was an unpleasant though a novel experience to be beneath such a cloud.

"Had a sudden change in the wind checked their course and caused them to settle, I do not suppose I could have escaped being fatally stung by them. A rough estimate made on the spot led to the conclusion that this cloud of mosquitoes was half a mile wide, and one hundred yards from front to rear. The depth of the mass I could not see, but it excluded the sunlight. The sound, as they passed, is best described by likening it to a long train of cars passing over a bridge.

"My duties as a naturalist called me to ascertain if the meadows were unusually free from these pests after the exodus of so many millions, but I could not see that this was the case.

"By careless exposure of my hands and face on the following evening, I found that there were enough left to make a night. in the marsh exceedingly painful, if not dangerous, through their attacks." 


\section{HYMENOPTERA}

\section{Bees}

Iva: Won't you tell us something about yourself, Miss Bee? You always seem so very busy, but we should like to hear your story.

Bee: Yes, I am busy. I have no time to spend in idle talk, but it is too cold for me to do much this morning. I suppose you have read about bees in your Bible.

Glenn: A swarm went into the body of a lion Samson had killed, and stored their honey there. At another time some honey that bees had made, dropped on the ground, and a prince who was leading an army came where it was, and was refreshed by eating just a little.

Bee: At that time bees were called Deborah, though who gave us that name I do not know. Our habits have been studied by wise men for thousands of years. The Greeks and Romans believed many fables concerning us. Some thought we were born in dead oxen, others that we came from lions; and if we were small and weak, then they thought we sprang from a calf. The Greeks gave us a pretty name, Melissa. One man spent sixty-eight years observing our ways, and another devoted his whole lifetime to studying our habits. The ancient Egyptians carved pictures of us on their monuments in their strange writing.

Glenn: Yes, I have seen it. It looked like this. I have

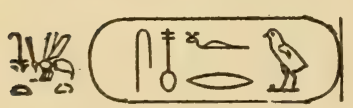
read that in Egypt the bee was the emblem of the people who obeyed the king.

Bee: I have heard that Napoleon had figures of bees made on his royal mantle, so you see great men have thought it worth 
their while to notice us. Still very little was known of our ways till glass hives were invented. Look at my body and see how well it is adapted to the purpose for which it was created.

Hazel: Do you belong to the Dip'te-ra family?

Bee: O, no! My family name is Hy-men-op'te-ra. Ptera means wings, and the other part means membrane. My name comes from the fact that I have four transparent wings.

Glenn: I thought bees had only two wings.

Bee: No, four. There are three kinds of bees,-queens, drones, and workers.

Iva: Which kind are you?

Bee: I am a worker. This is a picture of my mouth, made very much larger than it really is, so you can see its different parts. My trunk, or tongue, is the longest. If you should see it through a

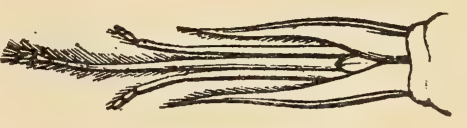

TRUNK OF BEE microscope, you could see the tiny hairs with which it is covered. These collect the juice of flowers, as I twist and bend my trunk about in them. This juice is taken into my mouth and then into my first stomach, or honey pouch.

Hazel: My auntie saw your trunk through a microscope, and thought it beautiful. The hairs were golden brown, and

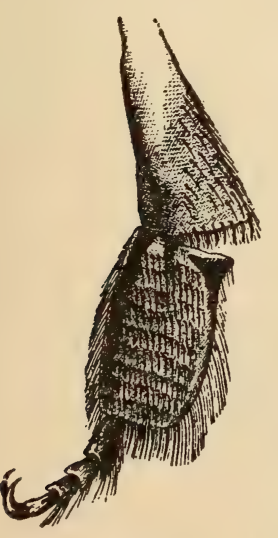
some of them glistened like silver, perhaps because of the honey on them.

Bee: While gathering honey my body gets covered with a yellow dust called pollen. I think you have seen it on flowers.

Harold: How do you get it off?

Bee: My legs are furnished with fine little brushes, with which I brush myself all over. The pollen is formed into tiny balls, which I carry home in little baskets on my hind legs. In this enlarged picture you can see the little 
shelf or basket in which I carry pollen. I have three pairs of legs, and these, with my trunk, are my tools.

Iva: What do you do with the pollen?

Bee: We feed it to the young bees, and it is part of our own food. We also carry pollen to the blossoms of fruit-trees, so there is a harvest of apples, peaches, pears, and cherries.

Hazel: Do you have eyes like the fly, Miss Bee?

Bee: Yes, compound eyes, or many eyes in one. My four wings carry me swiftly through the air, and I sometimes fly long distances to find honey and pollen. If I am working among flowers on trees, I fly up high, and then go to them straight and swift as an arrow.

Glenn: I see you have light- and dark-brown rings on your body.

Bee: Yes, I am an Italian bee. Some of my relatives are darker in color, and not so amiable in temper.

Hazel: In the British Museum auntie saw a picture that compares the sting of the wasp with the finest, sharpest needle.
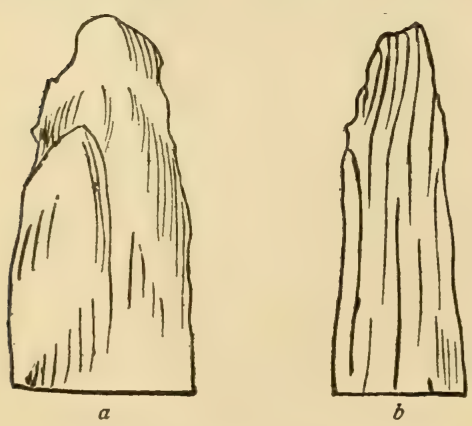

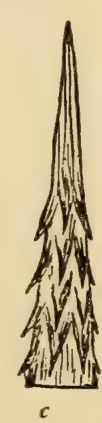

Drawings showing how much sharper the sting of a wasp is than the point of a pin or needle. Of course the drawings are greatly magnified. $a$, Point of a pin; $b$, point of a needle ; $c$, sting of wasp.
When placed under a microscope, the needle looks as though it were c o v e re d with little $\mathrm{knobs}$ and rough places, and ends in a very blunt point; while the sting tapers gracefully, has a smooth surface like glass, and ends in a perfect point. Bee: This compari- . son shows the work of God is more perfect than that of men. Glenn: Does the sting hurt because it is so sharp? Bee: The sharper it is the less it hurts, but the lance pierces 
the skin, and poison flows from a little bag into the wound, causing pain and swelling.

Harold: When Mr. Roosevelt was in Africa, he found if the bees were disturbed in their nests they tried to sting everybody in sight. Sometimes the crews of boats were driven into the water, and men and animals that could not reach a place of safety were stung to death.

Iva: Are there any bees that do not sting?

Bee: There are some in South America smaller than we are, and having very hairy bodies, that do not sting. They can not live where it is cold. Our drones and queens do not sting people.

\section{Hazel: What are drones?}

Bee: Our brothers. They are larger than I am, and more hairy. They make a loud buzzing sound as though they were hard at work, but are so lazy that even though they might be in a hive filled with honey they would starve to death unless we fed them. We let them stay in the hive till the honey season is nearly over, then hustle them out. Three or four workers chase them about, pull their legs

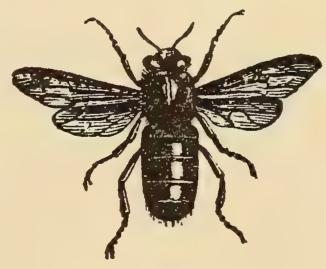

A DRONE and their wings, and sting them to death. Or else we do not feed them, and let them starve. We also destroy the larvæ and pupæ which produce them.

\section{THE QUEEN BEE}

Iva: Did you say you have a queen, Miss Bee?

Bee: Perhaps you would call her the mother bee, for she is treated as children should treat their mothers. If our queen is well and happy, all is order and contentment in our home. Harold: Does she look like a working bee?

$B e e$ : Her body is larger and longer. From these pictures 
of a queen, a drone, and myself, you will see how we differ in size and appearance. The queen lays all the eggs that produce bees. She sometimes lays 200 eggs $1 \int$ a day, or over a million during her lifetime. Glenn: I wish Queen 10 Bee. we had a few hens that would 1 ay eggs like that. Bee: $\mathrm{O}$ u r queen lays one egg in each cell of the

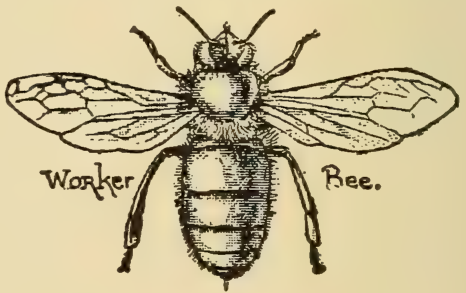
honeycomb. The eggs are little white mites about a sixteenth of an inch in length. For all they are so small, if all the eggs one queen lays were placed end to end, they would reach over a mile.

Hazel: Do all bees come from the same kind of eggs?

Bee: Yes; whether an egg produces a drone, worker, or queen depends on the kind of food with which the larva is fed, and also on the kind of cell in which it is reared.

Iva: Do you feed the baby bees?

Bee: Yes. The egg hatches in three days, and is then larva.Harold: Are all bees larvæ and pupæ before they grow up?

$B e e$ : Every true insect passes through those stages the first part of its life. These little white babies are very small, and we think they are pretty. We feed them carefully for five days, then cover them up tightly in their cradle cells. The baby bee first eats all the food we give it, then spins a little silk blanket in which it wraps itself. It goes to sleep, and in three weeks it wakes up a full-grown bee.

Glenn: How does it get out of its cell?

Bee: When it is ready, we assist and support it till it becomes quite strong. If it is a worker, it begins to work like the rest of us as soon as it comes from its cell. 
Hazel: Please tell us how an egg becomes a queen bee. Bee: This picture shows the size of the cradle cells of drones, working bees, and queens. The queen cell is made much larger than that of the working bee or drone. It is rough and uneven on the outside, like a peanut. The larva in such a cell is fed different food from what the common bees eat. If the egg which would produce a working bee were placed in a royal cell before it is three days old, it would become a queen. You see the cradle and food have much to do with it. It takes thirteen days for the egg which produces a queen to hatch. Before the queen is ready for her duties, she rests twenty-four hours. During that time we hover round her, brush her, and offer her honey. After that she goes outside the hive and flies around for a little time, then returns to the hive, and never

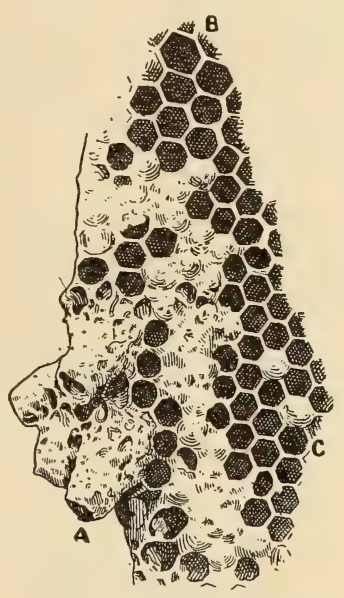

CRADLE CELLS OF BEES

A, Cell of queen bee; B, cells of drones; C, cells of worker bees. goes outside again unless it is when the whole hive swarms.

Glenn: Does every swarm have a queen?

Bee: It sometimes happens that one has none, but when this is so the bees are in the greatest disorder; they stop work, 'begin to steal from other colonies, and starve to death.

Iva: If one queen dies, can the swarm get another?

$B e e$ : It can if there are any eggs in the hive less than three days old. If one is found, it is tended with the greatest care. When it becomes larva, it is turned over many times in its cell, and a bee is appointed to give it royal food and watch over it for twelve days. When the proper time comes, the cell is closed, and all wait for the new queen to appear. Eggs which produce drones are put in larger cells than those of the working bees, and it takes them four days longer to develop. The 
larvæ of drones have their heads downward in the cells, while the queen bees have theirs upward.

Hazel: Do queen bees gather honey?

$B e e$ : No; their mouths are not fitted for that work, and they have all they can do to keep the hive supplied with eggs. They never sting except to sting another queen bee. When young queens are coming out of their cells, the old queen would sting them to death if the workers did not protect them. Sometimes two queens are found in the same hive, and then a royal battle is fought, which ends in one of them being stung to death. Francois Huber tells of a battle he saw between two queens which came out of their cells at about the same time.

Iva: Please tell us about it.

Bee: As soon as they saw each other, they were in a rage and rushed together in fury. When their bodies touched, and

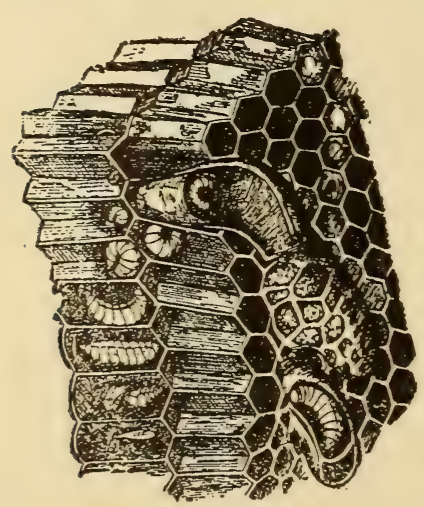

BEE LARVAE each could have stung the other, they let go their hold and ran away. They soon met again in the same manner, and again separated and ran away. The working bees were much disturbed. Twice they held the queen bees as prisoners for over a minute. The third time they came together, the stronger queen rushed on her rival when she did not see her coming, seized her by the wing, and stung her. The wounded queen walked slowly and painfully away, and soon died. After killing all other queens in the hive, the one that is left hunts for royal cells from which others might come, tears them open, stings the larvæ, and keeps up her efforts until there is no queen in that hive except herself.

Glenn: What if a strange queen came to the hive? 
Bee: There are guards at the door that would not let her enter. They would surround her and keep her a prisoner until she was starved or suffocated. They do not sting unless some one tries to rescue her. Sometimes men take our queen away and put another in her place. This does not please us. We stop all work, run hither and thither, and keep up a loup buzzing all the time. If our queen comes back, we become quiet and work as we did before. If a new queen is brought instead of the old one, we try to smother her if it is not more than half a day since the old one left. If she is not brought to the hive for twenty-four hours, we receive her gladly. A guard is appointed to escort her about the hive. The bees pat her, offer her honey, and there is a joyful buzz and flutter to show that we are pleased and happy because we have not been left without a mother.

Harold: Tell us how you live and work in your hive.

Bee: The working bees do not have to learn their trade. As soon as they come out of their cells they are busy, and need no one to tell them what flowers contain honey, how to gather it, how to find pollen, or how to feed their young.

Hazel: How many workers are there in a hive?

Bee: Some have more than others, but I should say there are from fifteen thousand to forty thousand.

Iva: I should think that would be more than could live in one hive.

Bee: When this happens, some of us leave to make a new home. This leave-taking is called "swarming."

Hazel: Do many leave the hive at once?

Bee: Yes, thousands. When about to swarm, we seem to lose our senses, and act as if mad. Our queen rushes about trying to destroy the young queens soon to leave their cells; but the workers will not permit her to do this. Then she runs all over the hive, followed by some of the workers. 


\section{$44 \quad$ Friends and Foes in Field and Forest}

The excitement becomes very great, and finally, with the queen leading, we rush to the door, and soon the air is filled with bees flying back and forth.

Harold: I thought queen bees could not fly far.

Bee: That is true of her at first, for she soon gets tired. and lights on the branch of a

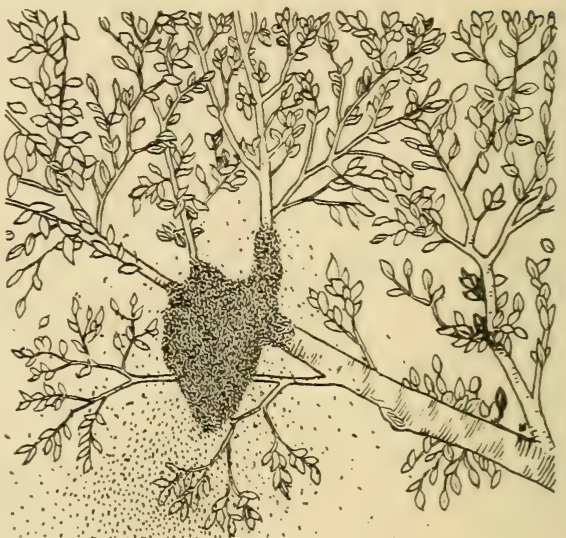
tree or some other object. We all gather together and formatuster according to the size of the swarm. Sometimes we sendout scouts to find a home before swarming. If they are successful, we rise in the air, and fly swiftly to our new hat tatonn But generally those who keep bees have an empty he ready, we are shaken into it, and are soon hard at work flling ot with comb and honey.

Glenn: How long do bees live?

Bee: A queen may live four or five years; the drones live as long as we see fit to let then, workers like myself live only a

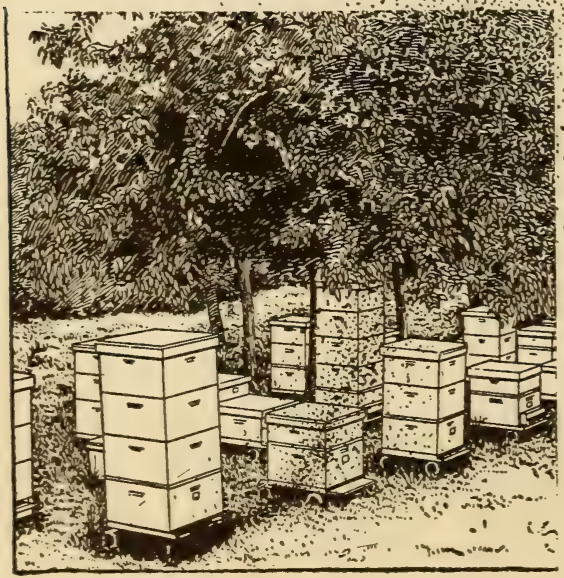
month during the busy sea"son, for we work so hard. The length of our lives depends on the time of the season when we are hatched, for some of us live through a long winter.

Harold: What do you do first when you are placed in an empty hive?

Bee: We stop up all the openings but one door. Some of us go to hunt for propolis. 
Iva: What is propolis?

Bee: A kind of glue which will not dissolve in water. Some think we get it from the buds of plants, but I shall not tell where we find it, and men may keep on guessing about it. We cover the walls of our home with propolis, and if there are glass windows, we cover them with a curtain of the same.

Glenn: How do you use the propolis?

Bee: Some of our workers bring it in tiny balls to the hive; others seize it, and go to work filling all the cracks just as a mason would use mortar. The work is divided among us; each bee knows what it has to do, and there is no grumbling. In this respect I think we may be said to be patterns of good behavior to children.

Iva: And you have all the little baby bees to care for and feed?

Bee: Hundreds of them, and each little one is as tenderly watched as though there were but one in the hive. I have never yet heard a nurse bee find fault because it is hard to watch over and feed so many.

\section{A BEE WITH SCISSORS}

Harold: I wonder what cut the holes in these rose leaves. $\mathrm{Ah}$, here is a little wonder-worker at it now. Please tell us your name?

Bee: My name is Mrs. Rose Meg-a-chi'le. Sometimes I am called the leaf-cutting bee, because I cut out pieces of leaf, which I use instead of wax in making cells.

Hazel: Do you have scissors, Mrs. Meg?

$B e e$ : Not scissors made of steel, such as you use, but my little jaws are so shaped and are so sharp that they serve me better. I grasp the leaf and let it pass between my legs so I can hold it firmly. Then I turn round and round and cut the leaf with my mouth. Before giving the last clip, I balance 
my wings to fly, and as the cut part falls from the leaf, I bear it away.

Hazel: Where do you build your comb?

Bee: It is the honey-bee that makes comb of wax, and lives in large colonies. I live by myself, and make my cells in soft wood or in the ground. I am very careful in selecting my home, and my first work is to make a smooth, round hole several inches deep, which leads to a good-sized chamber. In this I make a row of cells one on top of the other, beginning at the bottom.

Harold: Do you line the cell with rose leaves?

Bee: Yes; this round piece is for the bottom. Should you visit the South Kensington Museum in London, you could see cells such as I make.

Hazel: How many pieces of leaf does it take for one cell?

Bee: Twelve or sixteen. This is the shape of the cell, and

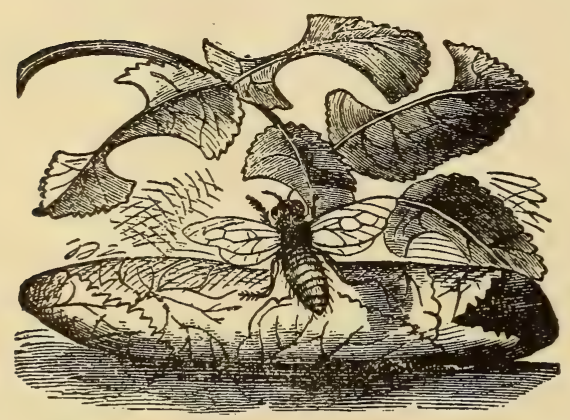

MRS. ROSE MEGACHILE AND HER NEST here is a picture of one after it is finished.

Glenn: How can you make them so perfect with only your jaws and your little feet to work with?

Bee: The One who made me taught me how. The very first one I ever made was as perfect as the last.

Iva: How many cells do you make?

Bee: Eight or ten. I twist and fold the pieces of leaf together, and place them so that two pieces do not join in the same place. The middle of one piece lies directly over where two edges come together, thus making each cell tight and strong. One cell fits into the next above it just as a thimble would fit into another a little larger. 
Hazel: Do you put honey into the cells?

Bee: Yes, I make a ball of honey and pollen for each cell. When one is ready to close up, I cut three pieces of leaf to put over the top, and they make the bottom of the next cell.

Harold: Are they all as round as these?

Bee: Yes, just as round.

Glenn: A carpenter would need compasses to mark out circles like that, and if I should

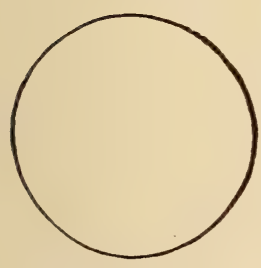

THE BEE'S CIRCLE try to draw one it would look like this.

Bee: God gave me wisdom in the beginning to do perfect work, and my cells are so tight that, though made of leaves,

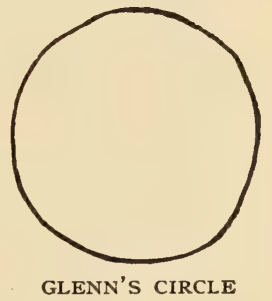
even the thinnest drop of honey can not leak out of them.

Ira: Where do you live?

Bee: I am found in countries where it is hot or cold, and even as far north as Hudson Bay.

Hazel: I should like to see one of your cells after it is finished.

Bee: We take good care to hide them from curious eyes, so they are not easy to find. After our work is done, we fill the top of the hole with earth or with the wood dug out in making it, and this is so cleverly done that no trace is left.

Glenn: Are there other bees that make cells of leaves as you do, Mrs. Meg?

Bee: Yes; there is my cousin called the upholsterer-bee. She likes bright colors, and so uses red poppies to line her cells. She wears a black velvet dress trimmed with white down, and makes a burrow in sandy soil. She is very particular to smooth out every wrinkle in the poppy leaves, and folds them over to make the top of each cell. In India some of my relatives make 
clay tubes in the hollow branches of trees, in which their eggs are laid.

Glenn: I have heard there are bees that are called carpenters. Are you acquainted with them?

Bee: Yes; one family is called Xy-loc'o-pa, which means wood-cutter. They live in very warm countries. They build

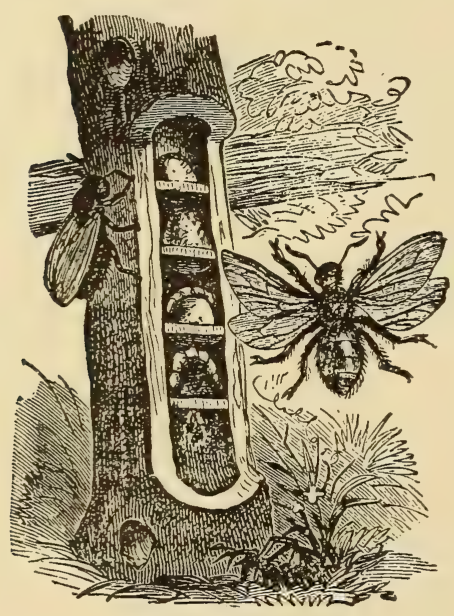

WOOD-CUTTING BEE their homes in a hole if they can find one in wood. They are lovely creatures, larger than bumblebees; they wear black velvet dresses, and their wings are dark blue: After selecting. some post or branch of a tree, the bee begins to bore a tunnel with her strong jaws. She first digs in a slanting direction for about an inch, and then suddenly turns and goes straight down twelve or fifteen inches, making a tunnel half an inch wide.

Iva: It must take a long time. Bee: Yes, several weeks, or nearly as long as it would take a man to build a house. Sometimes she makes three or four tunnels side by side. In the bottom of each she places pollen and honey, lays an egg, and then makes a roof of sawdust mixed with her saliva about an inch up the tube, and this forms the bottom of another cell, and so on to the top of the tunnel.

Hazel: Where does she get sawdust?

Bee: While she is boring her tunnel, she takes the fine shavings and puts them in a neat pile where the wind can not blow them away, so she has them at hand when needed for use. She makes a ring which soon hardens, then another, and still another, and finally fills it to the center. It appears some like the rings in an onion when a slice is cut through the middle. 
Glenn: The bee in the bottom cell must come to life first. How does it get out?

Bee: That is all provided for by this careful carpenter. She makes a back door into her house, as well as one in front. This she fills with soft sawdust paste, which will not hurt her baby's mouth when it is ready to leave its cell. Another curious thing is that the larvæ, when ready to turn to pupæ, turn their heads downward, so it is easy for them to get out.

Hazel: I have read of a carpenter-bee about as big as a grain of rice.

Bee: You mean another cousin of mine, I think-Ce-rat'i-na du'pla. She is noted for her industrious habits. She builds her cells in a broken twig of elder or sumac, and begins work by removing the pith in the center. This is as much of a task for little Ceratina as it would be for a man to dig a well two hundred feet deep, with his hands, for she has nothing but her mouth to work with. She makes a tunnel eight or ten inches long, and the walls are perfectly smooth.

Glenn: What does she do when the tunnel is finished?

Bee: She goes to hunt for pollen and honey, which she places at the bottom of the tunnel; then she lays a very tiny egg on the food she has provided. She makes a partition above this, provides more food, makes another partition, and so on until the last one comes within an inch of the top.

Hazel: That is like an apartment-house, each baby bee having a whole flat to itself.

Bee: After Ceratina's work is done, she uses the empty room at the top as her sitting-room, where she patiently watches and waits. One of her near relatives spins a film over the top of the cell she makes, something like the web a spider spins, and then brings five or six tiny pebbles, which she glues in the middle just over the hole. I suppose this is meant to be a notice to other bees, "Please do not come here." 
Glenn: Does the bee hatched from the first egg go out by a back door before the rest are ready?

Bee: No; this little carpenter makes no back door, so the oldest bee must wait till all its brothers and sisters have left their rooms. It is said that the young bees stand close together with heads toward the door, and when the little mother finds they are all ready, she leads the way to the outside world.

Hazel: Do they ever go back home again?

Bee: Yes, they return and have a thorough house-cleaning. They take out the old partitions, help their mother, and stay with her till they go to make homes of their own.

Harold: Do they live there all winter?

Bee: I am told that they do. When it gets cold, they go into the clean tunnel head downward, tuck themselves in, and sleep all winter until the warm sunshine wakens them. The last one to go in, the one that takes the coldest place, is the little mother. This is known by her wings being worn with making so many trips for pollen and honey, that her babies may have plenty of food. At last she lies down to rest, but takes the coldest place, still guarding her children; and there, it may be, her little life goes out before the springtime comes.

Harold: I wonder if there are mason-bees as well as carpenters.

Bee: Certainly. The mason-bees mix a kind of mortar made of clay and saliva, and build their homes against walls or timber, and when dry they are very hard. Oblong cells may be found inside. The mother bee likes to make her home pretty and neat, and so she covers the mud walls with nice, soft

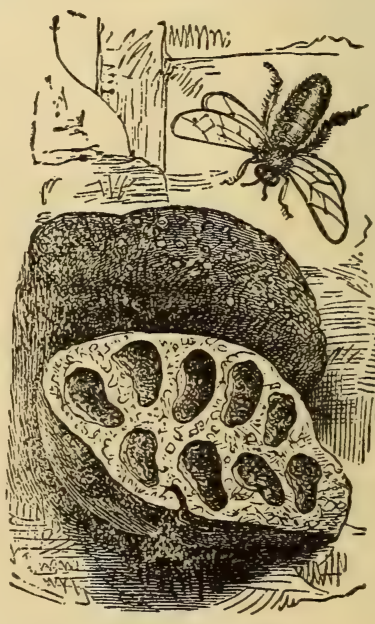

THE MASON-BEE AND HER HOME 
leaves. In each cell she deposits an egg and a cake of pollen and honey, and when all are finished she closes up the door with soft mortar that will not hurt the tender jaws of the baby masons.

Iva: Do they build a new house each year?

Bee: Sometimes they repair the houses made the year before, and sometimes, I am sorry to say, they go into a house that a sister mason is building, and drive her away.

Hazel: Can you tell us about any other kinds of bees?

Bee: My cousin An-dre'na is sometimes called the minerbee, because she digs into walls or hard earth such as can not be cut with a sharp knife. She bores a hole straight down several inches, makes a little round room, lays one egg, and leaves pollen and honey for the baby to eat when it is hatched. After her work is done, she comes out and shuts the door by filling it with earth taken out when digging.

Hazel: Are the wasps related to you?

Bee: They belong to the Hy-men-op'te-ra family, like myself, but I am not acquainted with them. Good-by.

\section{The First Paper-Makers}

Wasp: May I tell you a story?

Iva: Please do, Mrs. Wasp.

Wasp: While a man sat reading his newspaper, a wasp

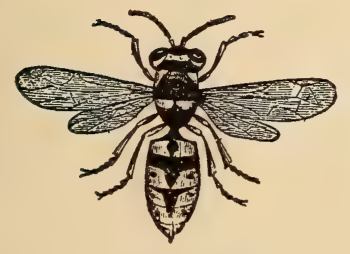

COMMON WASP came buzzing about his head, and he struck it with the paper so that it lay on the window seeming to be dead. In a few minutes another wasp came flying about, and seeing its relative lying there, came close and examined it. Soon it began to rub the senseless one, and kept on rubbing it all over. After a time the wounded wasp moved, and then the other dragged it gently along to the edge of the open window. 
After resting a little, it picked up its wounded companion and flew away with it.

Harold: That was kind, I am sure.

Wasp: My real name is Ves'pa. Don't you think that is a pretty name?

Hazel: It is nice enough for a girl. You seem to be quite good-looking, too.

Wasp: I suppose some young women would admire my figure because my waist is so small. I have heard that some of them wear their clothes very tight so that they may look like me.

Hazel: How many wings have you?

Wasp: Four. That is why I belong to the Hy-men-op'te-ra family. My front wings have rows of little curved hairs next to the back wings, and they turn backward at the edge, so the hairs catch in the groove and hold both wings close together.

Harold: Perhaps that is why you make such a loud buzzing when flying, for four wings would surely make more noise than two. What kind of house do you make?

Wasp: We build one of paper.

Hazel: Where do you get the paper?

Wasp: We make it. Long before men knew that paper could be made at all, every wasp had a paper-mill of

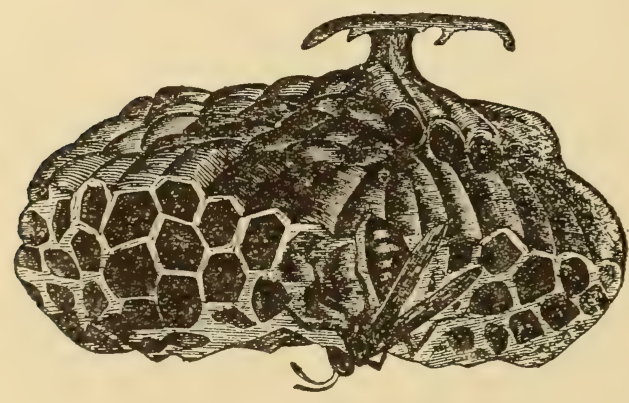

NEST OF PAPER-MAKING WASP

his own. My mouth is my mill. Some wasps in tropical America are so skilled in paper-making that they build their homes of white, gray, and buff cardboard. Réaumur, a man who spent much time in studying insects, once took some of 
this cardboard to a man to examine. After giving it the closest examination, he declared it was made by some man, and mentioned the name of one who he thought was the maker.

Harold: What do you use in making paper?

Wasp: Wood; we gnaw off a piece, chew it into pulp, and then work it with our jaws and feet till it is ready to use. It ri as from us that men first learned to make paper from wood. A great man, James G. Blaine, was talking with Dr. Hill, of Maine. He said there were not enough rags and cotton in the world to make the paper needed for all the papers and books, and unless paper could be made some other way, they would have to stop printing. Paper was then thirty cents a pound. Dr. Hill kept thinking where all the paper was to come from, and one day while he was watching some wasps build their rest, he got an idea. He captured the nest, took it to a papermill, and asked the manager why he could not make paper like that. The two men examined it closely. They knew it was made of wood, and that wasps chewed the wood. This was the starting-point of making paper by machinery from wood. It was not long till paper was reduced in price from thirty cents a pound to one and one-half cents.

Iva: Where do you build your houses?

Wasp: Sometimes in the ground, and sometimes we hang them up in a tree or some sheltered place. The hanging nests are shaped quite like a balloon. When I woke from my long. sleep last spring, I looked everywhere for a suitable place to build my house and rear my children. In England wasps usually build their nests in the ground; but in my search I came to an empty shed, and decided that mine should be hung from a beam near the roof. I first flew to a wooden post near by, and gnawed off some of its fibers till I had quite a bundle. After chewing them fine and working them into a paste, I flew 
to the shed and fastened this to the ceiling. Back and forth I went, again and again, till I had made a small pillar about an inch long. You see I lay the foundation of my house at the top instead of the bottom. Then I made three cells opening downward, and deposited an egg in each.

Harold: I should think they would fall out.

Wasp: They could not, for I fastened them to the side, and after that I shut them in. To protect them I made a paper umbrella overhead. Then I made more cells. It was not long till the first eggs hatched, and the larvæ must be fed. They grew very fast, and finally wrapped themselves up in soft silk blankets, which they spun themselves. Soon they came out full-grown wasps. Still the work went merrily on, for now I had others to help me. My older children cared for their younger brothers and sisters, and built new bedrooms, or cells, for our home. Terrace after terrace was added, and the walls brought down over them lower and lower.

Iva: Where do you make the door?

Wasp: At the bottom, and just large enough to let one wasp in at a time.

Harold: How many are there in a nest?

Wasp: From seven thousand to ten thousand.

Iva: What do you eat?

Wasp: We like sweet fruits and honey best, but we also eat insects.

Glenn: Do you live in your nest during winter?

Wasp: No, only in summer. When cold weather comes, we huddle together in the nest, and destroy the helpless larvæ. Most wasps die in autumn, but a few crawl into cracks and crevices, where they live through the winter, and it is they who start new colonies the next spring.

Hazel: Are hornets the same as wasps?

Wasp: No, they are larger and stronger, and their sting is 


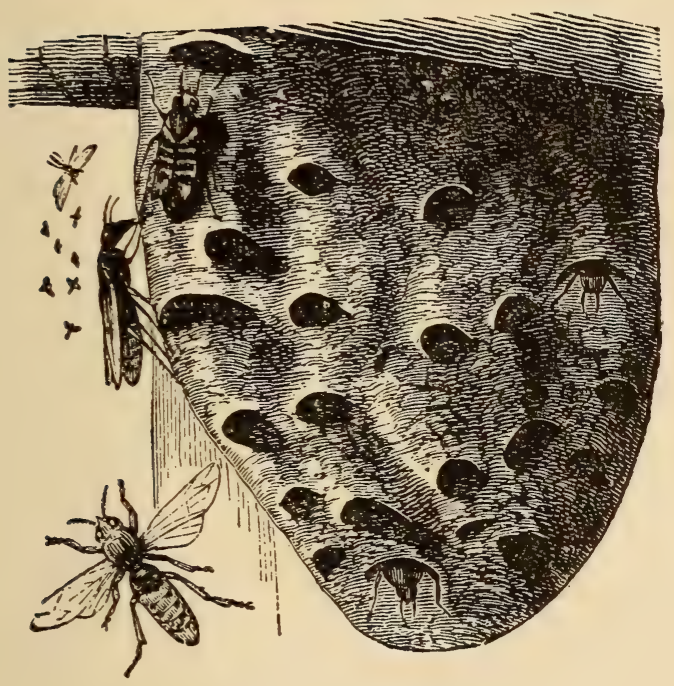

HORNET AND ITS NEST

very severe. They do everything on a bigger scale than we do. They build their nests in the trunks of old trees, and work at night as well as in the daytime.

Harold: Are there many kinds of wasps? $W$ asp: Yes, a large number. Some live by themselves instead of in colonies. Some make big nests four or five feet long and one or two feet wide. In the South Kensington Museum, London, may be seen many kinds which show great skill on the part of the builders. There one can see a tiny nest made in the hole of a spool of thread, and another in the hole of a tassel. One little wasp makes its cells under long leaves, which serve as a roof. Iva: Do you make honey?

Wasp: Some wasps do, but I am not that kind.

\section{Bonny Bombus}

Bombus: My name is Bom'bus, but I am sometimes called humblebee and bumblebee.

Hazel: I think your dress of velvet and gold very pretty, Mrs. Bombus, but your voice is so coarse and loud I am afraid of you. Do you have a sting like the honey-bee?

Bombus: I can show you very soon if you like. My home is out in the meadow, but I shall not tell you just where. We sometimes make it in the nest of a mouse, for that saves dig- 
ging a hole in the ground. Our home has a wonderful roof of moss. I worked very hard to make that roof, as all the moss had to be carded by drawing it through my jaws and fore legs. It makes my dwelling look so much like the ground surrounding it that it protects me from thieves, who would break it down and steal my honey. I usually line it with wax to keep out the rain. I have a hall, or passageway, about a foot long and half an inch wide, by which I enter.

Iva: Do you have comb inside like the honey-bee?

Bombus: No; we have wax cells, but they are the crad'es of my children. We do not believe in working for men who steal honey; so we simply get what is needed for our use day by day, though we keep a little on hand sometimes.

Harold: Do you have a large family?

Bombus: Not large like that of Cousin Honey-bee. She has from twenty thousand to forty thousand in

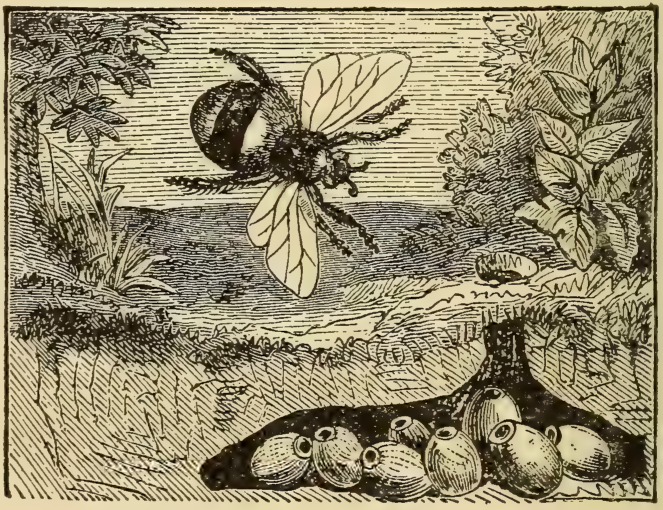

BONNY BOMBUS'S HOME AND HONEY JARS her family, while we have from twenty to two hundred. Hazel: Do you have a queen?

Bombus: No; we all live together - fathers, mothers, and children.

Iva: Your voice is so gruff, Mrs. Bombus, you must be a great scold.

Bombus: That noise which you call my voice is made by my wings, arıd as I am large and clumsy, people often think I am ugly; but I am not so apt to sting as the honey-bee. 
Glenn: Do you live in your snug, warm home all winter? Bombus: When cold weather comes, many in our family die; those that remain leave home and crawl into rotten wood, under a tuft of moss, or anywhere they can keep warm, and there sleep all winter. Last spring the warm sunshine woke me, and I began at once to build my house. I made some cells, and laid six or seven eggs in each, so there were several babies in each cradle. Thus my children learn to live and eat together. As they grew larger, the cells burst open, and I was kept busy repairing them and feeding the children. Like all larvæ they turned to pupæ, and when they were full grown, I helped them off with their covering. My children were kind to me, and we worked hard to make our home larger. They helped build other cells and brought food for the younger children. But they will eat the eggs after they are placed in the cells, so I am obliged to guard them very carefully. Did you ever hear of bees sitting on eggs to hasten their hatching?

\section{Hazel: Do bumblebees do that?}

Bombus: By breathing quickly we make our bodies warm, and then we sit on our eggs, just as a fowl does. One sits on them awhile, then another, and by this means they hatch more rapidly.

Harold: Is there more than one kind of bumblebee?

Bombus: There are about twenty different families. There is an insect that looks much as we do, which enters our homes, lays its eggs in our cells, and asks us to feed and bring up its children. We do the work patiently enough, but think them lazy and dishonest.

Hazel: Do you have any other name than Bombus?

Bombus: People call me Hummel, Bumble, Dumble, and Dumbledore, and some even call me Foggie. I do not know why they gave me so many names. 


\section{Little, but "Exceeding Wise"}

Iva: See this ant-hill, Glenn.

Glenn: Where are all the ants?

Harold: We will knock at the front door, and see if anybody is at home. Here they come in a hurry. When a caller knocks at Mrs. Ant's door, half the family go with her to see who is there.

Glenn: Will you tell us something about the ant family, Mrs. Ant?

Ant: We belong to the same family as the bees - Hy-men-op'te-ra.

Hazel: But bees have wings.

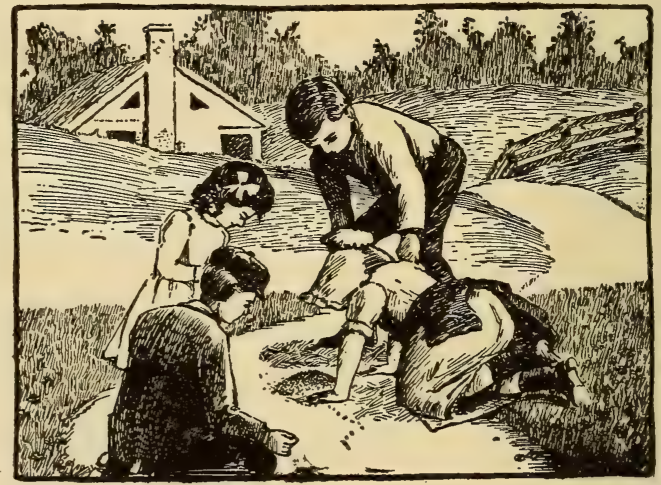

"SEE THIS ANT-HILL!"

Ant: We have wings, too. I unhooked them and took them off when I went to work so they wouldn't be in my way. Huber, the naturalist, once saw an ant in a box extend her wings, bring them before her head, cross them in all directions, throw them from side to side, and then all four wings fell off at the same time.

Iva: Can you put them on again?

Ant: No; when we decided to set up housekeeping by our-

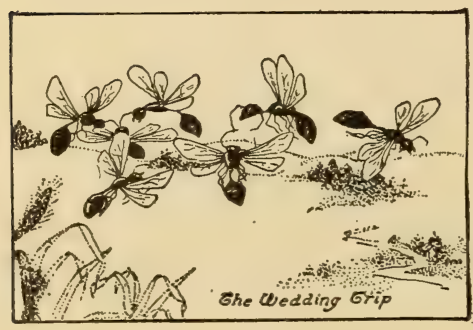
selves, we spread our wings and flew and flew. That was our wedding journey, and we were all kings and queens. There were so many of us that people complained because we flew into their faces. Many died, but some came to the 
ground safely. That is the only long journey I ever took. I found there was plenty to do to build a house, get it in order, and care for my children, so I unhooked my wings, and began to make a home for myself and my family. Sometimes the worker ants unhook our wings for us, and are as kind as possible.

Iva: Did any of your brothers and sisters stay with you?

Ant: A few of them. Queen ants are not jealous of their sister queens, gether. Like duce other Harold:

Ant: $\mathrm{We}$

As soon as we in the dirt to make like the bees. We live peaceably todig with my forefeet a rabbit. When the hole cover my body, I use my the earth into little balls. You lying all about the top of my nest them outside. But if the soil is carried out of the hole one grain

Do you work?

think it is queenly to work. take off our wings, we dig our house. At first I just as a dog digs for
is big enough to mouth to form see them here. I carry sandy, it is at a time.

Hazel: What a lot of work!

Ant: We are not afraid of hard work. The Bible says, "Go to the ant, thou sluggard; consider her ways, and be wise: which having no guide, overseer, or ruler, provideth her meat in the summer, and gathereth her food in the harvest."

Hazel: Have you no ruler?

Ant: We have kings and queens, yet only in the sense that they are the fathers and mothers. Every ant is a worker, and we think that is the way it ought to be in every home, whether of ants or people.

Harold: Have you many relatives, Mrs. Ant? 
Ant: Hundreds. There are one hundred twenty-four species, ard these, divided into families, are more than one can get acquainted with in a lifetime. There are big ants and little ants; red, black, white, brown, and yellow ants; there are mining-ants, farmer-ants, hunting-ants, soldier-ants, buildingants, and ants with dairy-farms.

Glenn: You have a big head for such a small body.

Ant: It takes a large head to hold all the wisdom the Creator gave me. My body is slender; my legs are long, so I can run swiftly; my eyes are not very large, but those of my brothers are larger; I have two strong jaws, with tiny, sharp teeth. These are useful as scissors, pinchers, shovel, fork, and sword.

Hazel: Your antennæ, or horns, seem to be crooked.

Ant: They bend like an elbow, and are useful in examining things, and to talk with. One of my friends found a fat fly she wanted to carry home for dinner. She tugged and pulled and worked for twenty minutes, but could not carry it any more than a little boy could carry a big man weighing two hundred pounds,

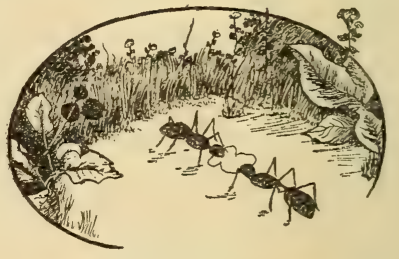
ANTS TALKING so she left the fly, went home, and soon came back with twelve ants to help her.

Harold: A woman once watched some ants moving their babies into a new home. She hid three of the little white bundles behind a stone. Soon three or four ants rushed out of the nest and ran wildly about in circles as though they were hunting for something. At last one found the babies, took one and ran away. This ant told the news, and two ants went to the stone, and carried the other babies back to the nest.

Glenn: Can ants count and talk?

Ant: Surely we can. We just touch one another with our horns, and we have no difficulty in understanding what is 
meant. And some ants have stings; and some have an acid which is poured into wounds made by their jaws which causes them to sting and burn.

Harold: I read of a man who, to keep the ants out of his sugar basin, placed it in a pan of water, but the ants liked the sugar too well to give up trying to get it, so they climbed the wall to the ceiling over the sugar, and dropped into it.

Ant: Some of them must have fallen into the water.

Harold: They did, for the ceiling was high; but ants on the edge of the pan tried to fish their companions out by stretching out their bodies as far as possible; they were afraid to plunge into so large a lake after them. Then a few ran to the ant-hill, and brought eight soldier-ants, which threw themselves in to the water, swam around, seized the drowning ants, and brought them to shore. Though they were half dead, their friends rolled them in the dust, brushed them, rubbed them, and stretched themselves on them to warm them. Then they rolled and rubbed them again.

\section{Hazel: Did they live?}

Harold: Of the eleven that fell into the water, four were restored. The fifth, when able to move its legs and horns a

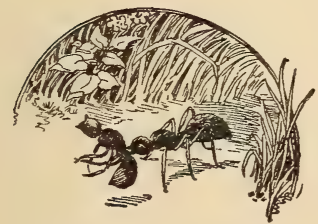

BEING CARRIED HOME little, was carried home. Six died, and were taken to the ant-hill.

Hazel: A woman in Sydney, Australia, killed a number of soldier-ants, and in half an hour went back where she had left their dead bodies. A large number of living ants were about the dead ones. Four or five went to a little mound in which was an ants' nest, and in about five minutes they came out, followed by others. All fell into rank, going slowly two by two to the dead ants. Two took up one dead body, then two another, and so on. There were two ants bearing a body, then two without one, then two others 
with a dead ant, and so on until about forty pairs were in line. The procession moved slowly, followed by about two hundred ants. When the ants bearing a body would stop and lay down their burden, it was taken up by the two behind them. Thus

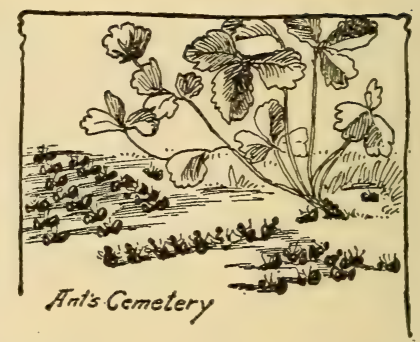
they journeyed until they arrived at a sandy spot near the sea. Here they dug holes with their jaws, and into each hole a dead ant was laid. Then the graves were filled up. But six or seven of the ants had tried to run off without digging. These were brought back, and at once killed. A single grave was dug, and all dropped into it.

Ant: An insect called the velvet ant, though she is not really an ant, is related to us. She wears a beautiful red dress, but one forgets how pretty she looks when he sees what a temper she has; she seems to be angry all the time, and tries to sting every living thing that crosses her path. Her mate has wings, and flies whenever there is a fresh outburst of wrath. She will even try to fight a man if he is within reach, and she has

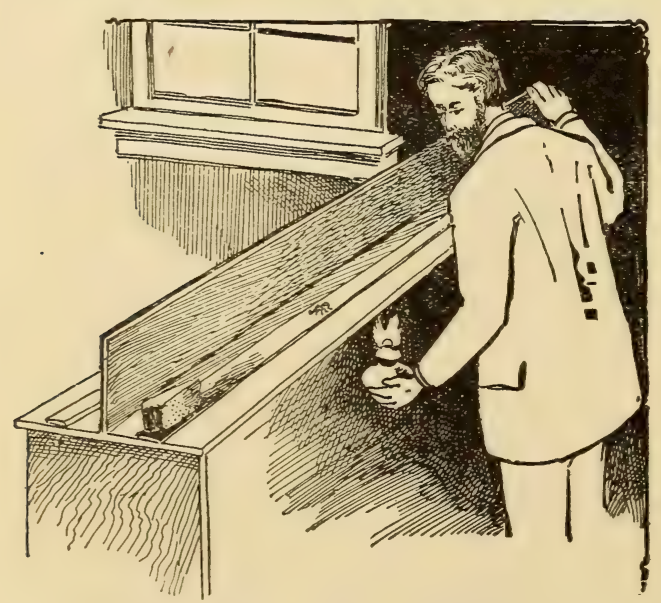

THE STUDENT AND HIS EXPERIMENT

a powerful sting. She keeps up her buzz, buz-z-z whether at home or abroad, and her loud voice can be heard above all the cheeping and chirping of more peaceable insects twenty feet from her.

Hazel: I should not care to be like her.

Ant: Now let me tell you about my ant friend 
that was carried to a great university in Pennsylvania, by a young man who wished to learn whether ants can remember. He made a little railway with two tracks separated by a high partition. He painted one track red and the other blue, and at the end placed a piece of rich cake. Then he placed my friend at the beginning of the railway. She ran to get a piece of the cake, taking the red track, and the young man put a blazing lamp under the roadway and heated it so hot that she burned her feet; but still she kept on till she got the cake. Several hours later he thought he would see whether the ant remembered her uncomfortable journey, and so placed her where he did before, with the cake in plain sight. She waited a moment, then took the blue path. Then he blocked up the blue path, and the ant went without the cake rather than travel over the red path to get it.

Hazel: Peter Huber divided an ants' nest, putting part under a glass bell where he could watch the ants. The others made a nest at the foot of a chestnut-tree. They were separated four months, and then those under the glass were taken to the rest of the family. They were very joyful when they met. They touched one another with their antennæ, and all went together into the nest under the chestnut-tree.

Ant: We have been known to recognize one another after being separated two years, and if eggs are taken from one anthill and reared in another, the ants will be recognized when they return to their own family. We never have family quarrels. If we find anything good to eat we do not hide away and eat it alone, but invite our brothers and sisters to have a share. We help one another all we can. If one ant gets very tired, another carries it on its back. If one has a heavy load, others are ready to help carry it. Sometimes we work so hard that we forget to eat, and then other ants bring us food. If we get hurt, we are carried home and cared for. A man once saw an ant 
which had one of its horns torn off, and another ant came and poured something on the wound; so you see we have doctors and nurses.

Hazel: How long do you live?

Ant: The worker ants live many years, which shows that work is good for those who would live a long time.

Iva: Do you work at night?

Ant: In hot countries we do, and rest during the day. We stop work and take a nap when we get tired; we lie on our sides, rest on our hind legs, or lie down together in a heap. When we waken, we stretch and yawn. When crowded, we are not rude, but keep good-natured.

Hazel: Do all ants do the same kind of work?

Ant: No, some act as nurses; some gather our food; others build our homes; some herd the cows; others tend the crops and harvest them; some are soldiers, and others sentinels.

Iva: What do the sentinels do?

Ant: It is their duty to keep enemies out of the ant home. They watch at some distance from the ant-hill, and give an alarm if a foe appears. They first run home and stand at the door of the passageways, and tap every one they meet with their antennæ. It does not take long for the alarm to spread throughout the whole household, and the ants rush out by hundreds to fight for life and liberty.

Harold: Do the sentinels close the doors at night?

Ant: Yes; they work from both the outside and the inside. Sometimes small stones are used for closing the passages. One family of ants has sentinels that use their heads as gates. It would not be easy for anything to get inside without waking the guard, where this is the case. Some of the ants do sentinel duty while they are watching the nest from some point near by, and they are ready to fight if any enemy appears. 


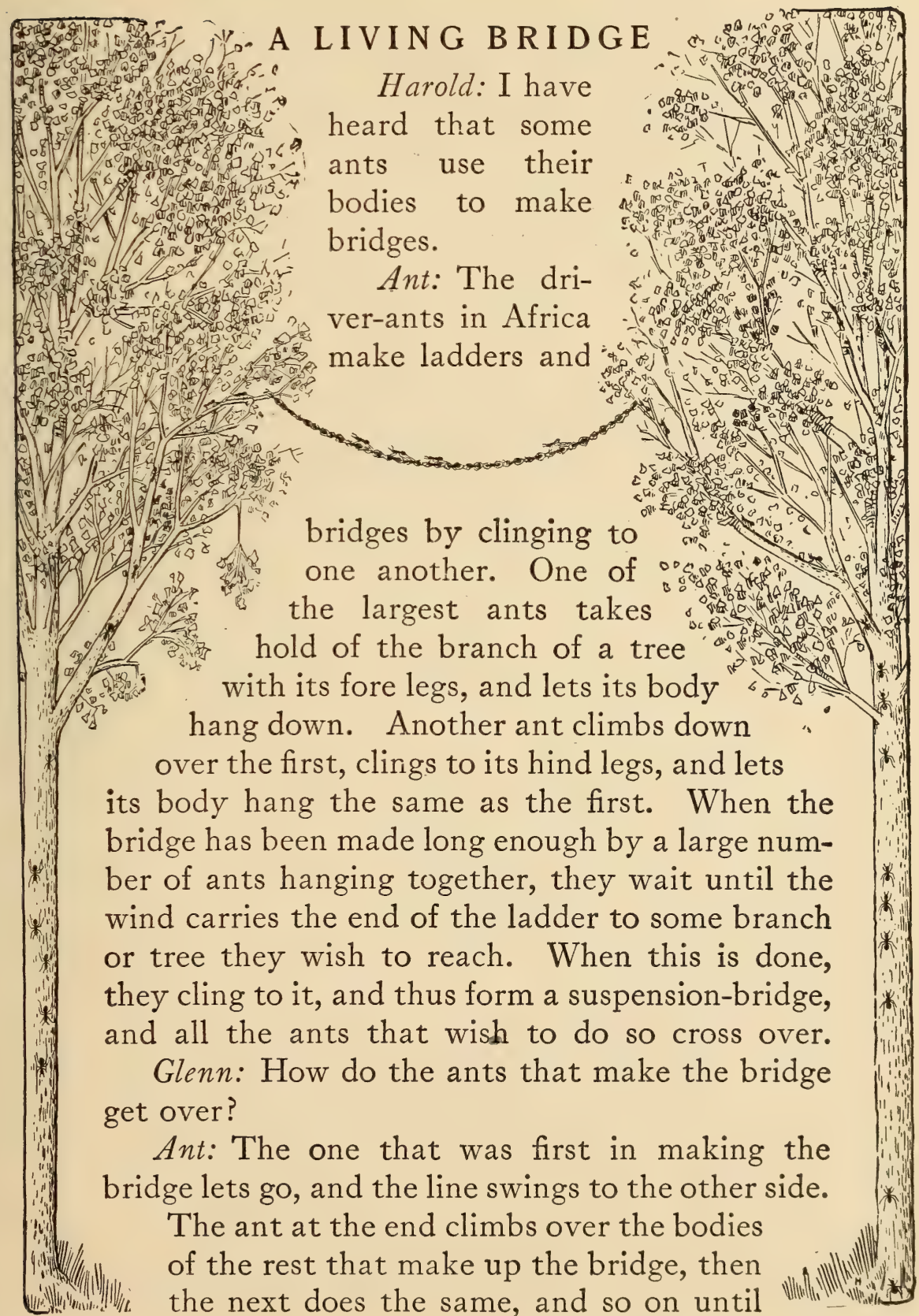


the whole line have joined their companions that passed over before them.

Hazel: I have heard that some ants use their bodies as storehouses for food.

Ant: They live in Mexico, and have also been found in Colorado and Australia. Early in life the stomach of some of these ants grows until this part of its body is as large as a currant or a small grape. Their bodies are full of sweet sirup, and they retire into little rooms in their home and hang by their feet from the ceiling. They are really little honey-pots, and when the workers are hungry they go to one of these live storerooms, and are fed just as a bird feeds her young. The Mexicans and Indians sometimes collect these ants and eat their honey. It is also used for medicine.

\section{Harold: What do ants eat?}

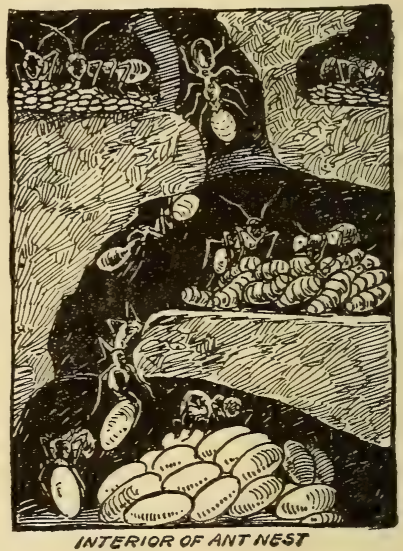

Ant: All sorts of things - meat, fresh or dried, grains, fruit, and especially sweet things, such as sugar, sirup, and honey. We do not chew our food, but lick it with our rough tongues. Some ants sit up like squirrels when eating. If the food is hard, we moisten it. The teeth of old working ants are sometimes worn off.

Iva: I shouldn't think you would like to work all the time. Ant: We work awhile and then we rest, and we have our playtimes, too, when we jump and wrestle, play games, carry one another in our mouths, and have a good time. But we never mix work and play.

Hazel: Please tell us about the parasol-ants.

Ant: They are large, and are called parasol-ants because when carrying to their nests pieces they cut from leaves, they 


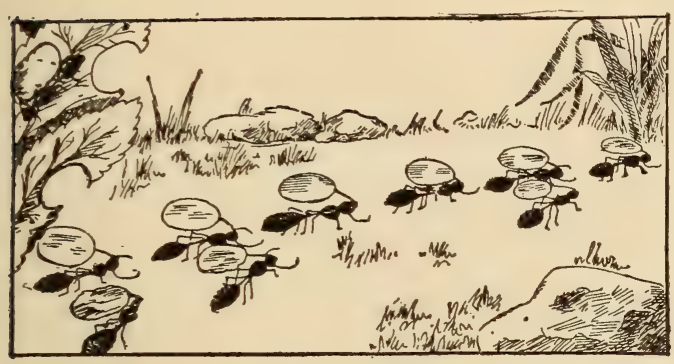

PARASOL-ANTS

hold them over their heads like a parasol. Each piece of leaf is about as big as a dime, and it is carried by a little stem.

Glenn: What do they do with the leaves?

Ant: They tear them into small pieces, store them in their nests until decayed, and use as food a fungus which grows on the rotten leaves. You see they are mushroom growers and eaters. When gathering the leaves, they march along one after another, and look like a procession of living leaves. The leaf-cutting, or parasol-ants, are found in Central America, and there do great harm to orange, lemon, and mango leaves. All ants are careful to keep themselves and their homes clean. Ants clean themselves in much the way that a cat does. They draw the brushes on their legs through their mouths and rub themselves all over. That is their way of taking a bath. Sometimes one ant assists another in making his toilet by brushing him.

Iva: Mrs. Susan Lee saw, near the Guadalupe River, a beautiful vine with leaves smaller than those of the smilax, of a pale, tender green. Its root was about five feet from a cottonwood-tree, and four or five inches wide, becoming narrower as it approached the tree. No stems nor tendrils could be seen, so thick was the growth. The vine branched just above the ground and climbed the trunk and branches, growing more and more slender, until, far up, it was only a threadlike line of green. Soon it was prevaded by a tremulous motion, and the leaves were not stationary. She picked up a twig, and found a brown ant under it, about as long as her little finger nail. 
Each leaf was held in the mandibles of an ant so as to conceal its body, and the ants were coming down the tree. It was a nest of umbrella-ants. Such ants are found in the tropics, where they carry bits of leaves over their heads as if to protect themselves from the sun; but here on the banks of a Texas river, was a colony of them, shading themselves where there was no sun, and completely hidden by their covering of green. The spot where the vine seemed to have its root was the opening of the ant-hill. By some instinct the ants learned that the topmost branches of the cottonwood had put out their first small leaves. So they climbed the great

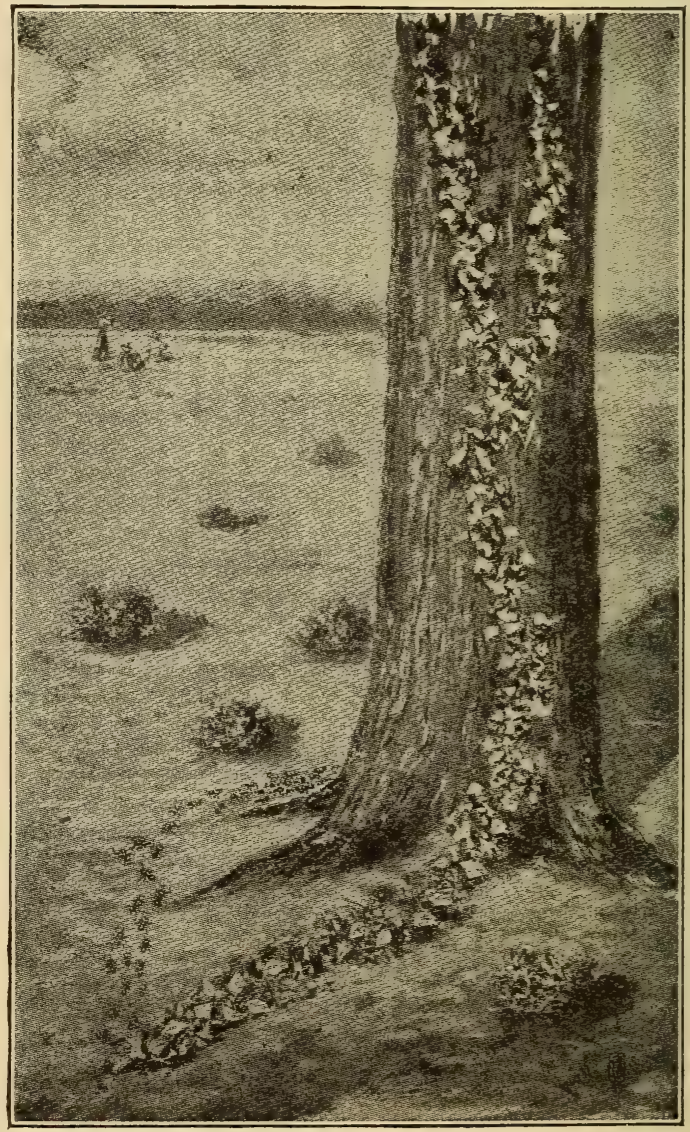

THE MOVING VINE OF UMBRELLA-ANTS distance, and cut off and brought down the leaves to feed their young. The ants coming from the nest went to the farther side of the tree, and climbed up where they would not interfere with the leaf-bearing thousands coming down

Hazel: Some people found a bottle with a few drops of 
whisky close by an ant-hill. They emptied the whisky into and around the ant-hill. The ants came running out, and even tumbling over one another in order to get away from the stuff. Then they went to work. Every stone, stick, weed, or leaf that had the smell of whisky was carried away. A large hole was left where they had been at work. While many ants got rid of the whisky, some attended to a grasshopper that was given them. They sawed and pulled it in pieces, and stored it in their underground storehouse.

\section{The Farmer-Ants}

Glenn: I have often wondered, Mrs. Ant, how small creatures can carry such heavy loads.

Ant: Our jaws are strong, and we are not easily discouraged. We may stumble and tumble over and over again, and roll

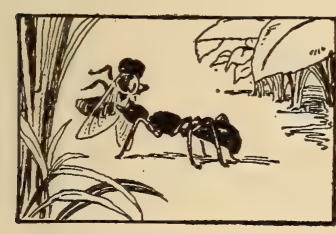

A HEAVY LOAD down-hill with our load, but still we try again, until we succeed. Do you see four or five ants carrying that big beetle? They have brought him an inch nearer while we have been looking at them.

Iva: One of them is running away. Ant: She is lazy. Two of the ants are bringing her back, and are cutting off her head; they did not punish her until they had tried twice to make her do her duty.

Glenn: I thought all ants were great workers.

Ant: A few do not like to work, but nearly all are industrious. In Texas, Florida, and a few other warm countries, ants have been found that clear the ground of weeds, and nothing is allowed to grow on it except a kind of grass which bears a seed called ant-rice.

Hazel: How can ants cut down weeds?

Ant: They cut down those as thick as your thumb and 
two feet high, and drag them away. That is like a man cutting down trees one thousand feet high and one hundred feet through, to make a

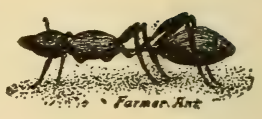
farm. With their strong jaws they pull and twist and cut and push. Sometimes one ant climbs to the top of a weed to bend it over, while another gnaws away near the ground till it tumbles down.

Iva: Do they keep their gardens clean?

Ant: Always. Their farms are round, and sometimes as large as a big room. Near the center there are one or two zwo ants enting grass openings which lead to the rooms below.

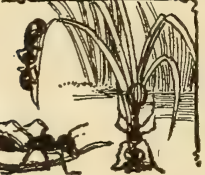
These may be several feet underground. They are used as granarie's to store their grain, and also as living-rooms for the family.

Hazel: There is a Bible verse, written by the wise man, that says, "The ants are a people not strong, yet they prepare their meat in the summer." Prov. 30:25.

Ant: That is what these little farmers do. Seeds, when ripe, fall to the ground; the ants tear off the husks, and then store the seeds in the rooms below.

Harold: I should think they would sprout and grow down under the ground.

Ant: The ants carry them out to dry after a shower. Sometimes they cut the kernels so they

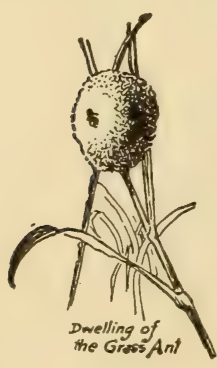
can not grow.

Glenn: That must make a lot of work. I think they must be the ants that provide meat in the summer and gather food in the harvest.

Ant: They are not afraid of work. After a crop is gathered, they clear the land of all the old stalks, so it is

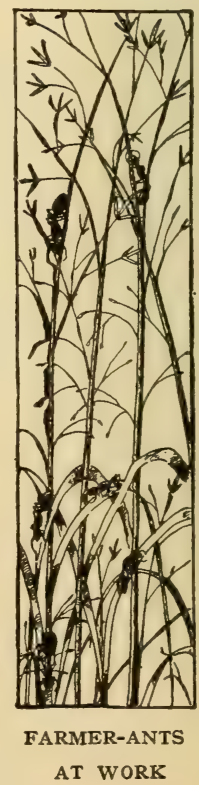


ready for the next crop. They also build roads sixty feet long and two or three inches wide, so they can carry grain that grows outside the home farm.

\section{THE DAIRY-ANTS}

Ant: I am going now to milk my cows.

Hazel: Do ants have dairies as well as farms?

Ant: Just turn up that leaf and you will see a whole herd of cows.

Iva: Those are plant-lice, or aphids.

Ant: They furnish us rich, sweet milk. This sugary liquid

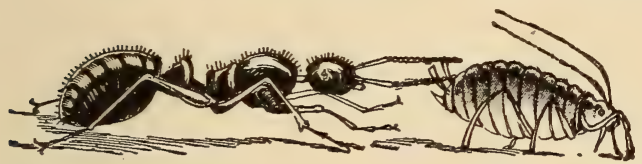

ANT MILKING ITS CoW is the food of the baby plant-lice until they are able to suck the juice of plants. I pat one of these little creatures on both sides, so, with my feelers, and it gives out two little drops of sweet drink for me, and I lap it up. This picture shows how it is done, only the picture represents us as much larger than we really are. We take care of our cows and protect them from harm. Sometimes we build little stables of earth to keep them in, and at other times we let them live in our own home. Ants have been known to build covered roadways from their cattle's grazing-ground to their own nest, and sometimes they drive their cows to pasture, where they feed on the grasses, leaves, and roots nearest the ant-hill.

Harold: Sir John Lubbock found that ants rear these insects as carefully as they do their own babies. As winter draws on they gather the eggs, carry them to their nest, and feed and tenderly care for the young when they are hatched, until spring. They then carry them back to their own food plant. The red and yellow ants are very fond of the sweet fluid obtained from the aphids. 
Iva: You said there are soldier-ants. Why do ants want to fight?

Ant: Sometimes they go to war about their plant-lice, for an ant-hill is rich according to the number of aphid cows it owns. They are the ants' treasure. and if those inhabiting one hill take the cows belonging to another, they may be rescued by their rightful owners. There is a large blood-red ant that makes war on the ashy-black ants, or the mining-ants, to make them their slaves. They are sometimes called soldier-ants. They have big heads, and like to eat and sleep. The russet ants attack the ashyblack ants and make them serve as slaves, for the former will not work.

Harold: How do they fight?
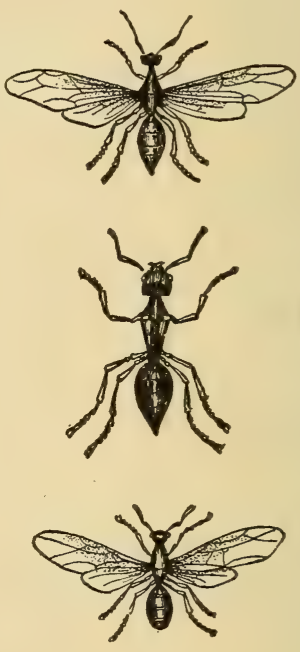

ASHY-BLACK ANTS - MALE, WORKER, AND FEMALE

Ant: They rear on their hind legs, and bite with their strong jaws. They have a bulldog grip, and when once they seize their victim, they never let go. Sometimes an ant may be seen

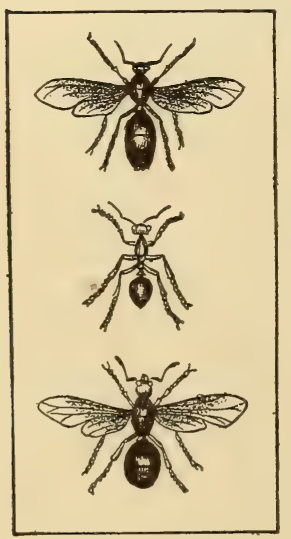

BLOOD-RED ANTS

carrying on her leg the head of a soldier-ant which it has bitten off in some hard-fought battle.

Hazel: Peter Huber once watched a battle. The army that went out to fight formed a column about three or four inches wide and ten feet long. The ants went in regular order, and the soldier-ants kept close together. They crossed a road in their march, and went into a meadow where there was a nest of ashyblack ants. The sentinels saw the army coming, gave the alarm, and they tried to de- 
fend their home. The red ants rushed forward, attacked the black ants with great fury, and the battle was soon over. Then they entered the nest, and in a few minutes each soldierant came out carrying the pupa or larva of a black ant in its mouth. Soon the soldiers formed a straggling line and returned to their own home.

\section{SOME LAZY ANTS}

Harold: What do the soldier-ants do with the larvæ of black ants?

Hazel: They don't like to work themselves, and so make slaves of them as they grow up, and they do all the work. It is said the soldier-ants treat their servants kindly.

Glenn: It seems strange that ants should be so lazy that they want slaves to wait upon them.

Ant: They would rather fight than work. If they have slaves enough, they will not make their nests, clean themselves,

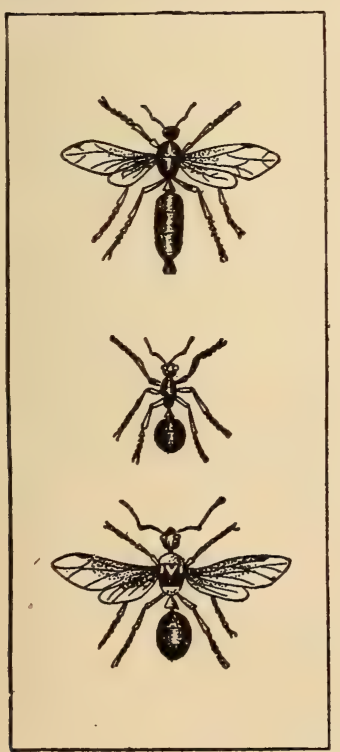

MINING-ANTS nor feed their babies, and they even have slaves to give them their food. Peter Huber placed thirty of these lazy ants in a box where there was plenty of food. All of them nearly starved to death, and some died. Then a single slave-ant was put in the box. She fed the fainting ants, took care of the younger ones, and made a nest for all.

Harold: Do ants have trades like the bees and wasps?

Ant: Yes, there is the mason-ant, which makes her nest of little mud balls laid up like bricks. The carpenter-ant cuts into logs and trees to make its home. Here is a picture of a family of mining-ants. One 
ant makes a woolly nest, and another lines hers with leaves. Hazel: Are ants of use to men?

Ant: Like the bees they carry pollen to plants and flowers, and that makes the seeds grow. In parts of South America and Africa there are so many ants that people can not live in the same place with them. The driver-ants in Africa and the army-ants in Central America march in columns several miles long, and eat everything that comes in their way. When they come to a building, the people run for their lives. They eat all the food, and bite the people; their bite is almost as painful as the sting of a wasp. While most ants bite, some have stings, and are not afraid to use them on anything they count as an enemy. In some parts of Brazil the ants control the country; for men can grow nothing that the ants like, and so they decide what crops must be grown.

Harold: I should like to see how an ant-hill looks inside.

Ant: The family to which I belong build partly above and partly under the ground. We make halls, or passageways, down deep in the earth, with rooms arranged in stories. We carry all the earth and rubbish to the surface, and use it to construct the building above ground. We make passageways, chambers, nurseries, and large rooms. We have a room in the center sometimes as large as a man's head. This is where we gather together to plan our work and to visit. Some of our rooms are shaped like an egg, and the walls are always smooth and well finished. We like to build near some green tree or shrub, as it makes a shelter for our home, and the leaves furnish pasture for our cows.

Harold: What do you work with?

Ant: We have nothing but our strong jaws.

Harold: I should think your walls would fall in.

Ant: They would if we did not finish them properly. I belong to the mason-ants. We build best where the soil is moist. 
We roll up little balls of earth, stick them on the walls, and then pat them smooth with our feet. We work on all parts of our dwelling at the same time. Over the underground rooms we build a rounded roof, or mound, of little stones, balls of earth, bits of sticks, leaves, or anything within reach.

Hazel: Are there rooms in the upper part of your house?

Ant: Yes; and there are also avenues, which open outside. We close the openings when it is rainy and cold, and also at night. Some ants dig long galleries underground. At one time sulphur smoke blown into an ant-hill was seen to come from holes two hundred feet away. The sauba- or coushie-ant builds domes two feet high and forty feet long. Our homes are also fortresses, built to protect us from our enemies. Sometimes we have eighty stories, one above another,- - forty below ground, and as many above.

Hazel: Auntie saw ants' nests in Australia, built on top of the ground six or eight feet high, and nearly as broad.

Ant: I think she did not visit them, for the ants that live

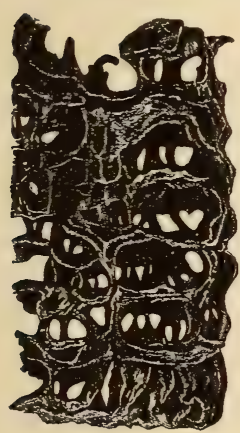

A HOUSE IN WOOD there are not afraid to attack a man if he comes too near. They have powerful jaws, and inject an acid which makes the wound very painful, like a sting. Did you know there are carpenter-ants as well as carpenter-bees?

Glenn: Do they build nests out of wood? Ant: Not out of wood, but in it. Here is a picture of one made in an oak-tree. The carpenter-ants, with no tools but their jaws, bore tunnels and rooms in the hardest wood.

\section{BABIES IN WHITE}

Glenn: I saw some ants that had been disturbed, running about carrying what looked like little grains of rice. Were those ants' eggs? 
Ant: No, indeed! If you had looked carefully you would have seen that what you thought were eggs were nearly as large as the ants

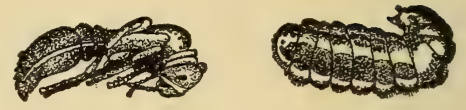

LARVA AND PUPA OF THE RED ANT themselves. An ant's egg is so small that you can hardly see it without a microscope. Those white bundles were ant babies - pupæ, I believe you call them. The ant lays her eggs in the passages, and the workers pick them up and carry them to rooms especially prepared, where they care for them. In two weeks the larvæ appear. Each one has a head, mouth, and wings.

Hazel: Not long ago an insect flew into my hair. It dropped on my dress, and I saw it twist and wriggle about, and then one of its wings dropped off. Still it kept wriggling, and soon another wing was gone. I thought it must be an ant, and put it under a glass, and it tugged away till it unhooked and laid aside all four of its wings.

Ant: I am glad you saw this, for one may watch some time before he sees an ant take off its wings, and get ready to work.

Iva: What do the baby ants eat?

Ant: The nurses feed the larvæ just as a mother bird feeds its young, and they are kept busy. The first work given to young ants is to care for their baby brothers and sisters, and they are kind little nurses. In some families the babies of the same age are kept together, as a teacher keeps pupils in the same class together.

Harold: Do the nurses have anything to do except to feed the little ones?

Ant: They carry them into the fresh air every pleasant day. As soon as the sun rises, the ants nearest the top of the house go to tell those in the lower rooms that it is time to wake up. They touch them with their horns, or give them a 
little shake with their jaws. Soon the passages are crowded with nurses carrying the babies out into the sunshine. Besides carrying the babies out, the ant nurses see that they are kept very clean, by licking them, brushing them, and stretching their skin. After a time the larvæ spin a silky white cocoon, in which they lie perfectly still until ready to come out. It is at this stage that they look like little grains of rice. After the nurses take the babies out in the sunshine, and when their work is done, they gather together and take a rest. If an enemy appears, each nurse seizes a baby in its mouth and runs for a place of safety.

Glenn: Do the nurses help the baby ants out of their pupacases?

Ant: Yes, that is part of their duty. They tear off the coverings, feed the little ones, teach them to walk, and stay close by to help them till they can care for themselves. The younger ants are shut up in the ant-hill until the time comes for them to fly away and make homes of their own.

Glenn: When ants move from one place to another, do they carry the larvæ and pupæ with them?

Ant: They would never leave them behind any more than your mother would leave the baby when she moves from one house to another. They never forget to care for those that are sick and old. They, too, are carried to the new home.

\section{HAPPY IN A THORN}

Iva: Do ants make their homes anywhere else than in the ground and in wood?

Ant: There is an ant in Brazil which makes a nest as round as a marble, with warty projections, hanging from trees like a wasps' nest. An ant in Sierra Leone makes a nest that looks like a large brown toadstool, only it has four tops instead of one.

Glenn: I have heard that some ants make a nest of leaves. 
Ant: Captain Cook found these ants making their nests in Australia. The leaves they used were as broad as one's hand.

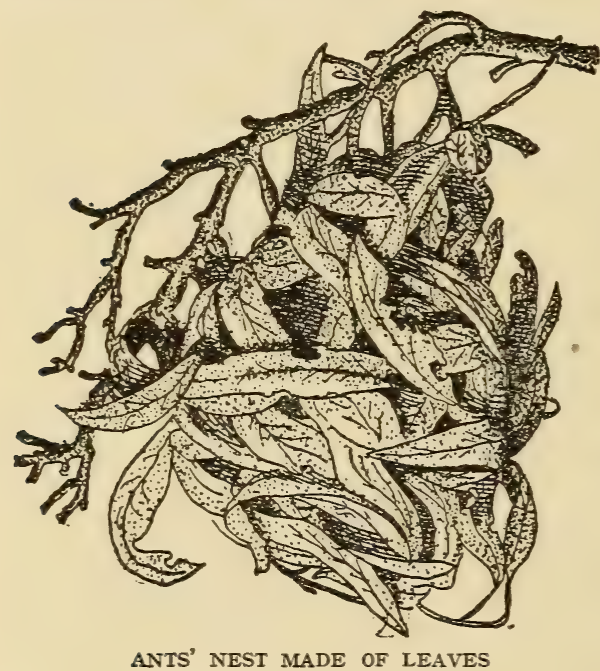

Thousands of ants united to bend the leaves so the tips would touch, and thousands more applied a kind of glue that fastened them together. Here is the picture of the leafy nest of a tree-ant in India. One of my cousins makes for herself a quaint little house in the bull's horn thorn, a kind of acacia-tree which is covered with sharp thorns shaped like horns. Here is a picture of one of them. When the thorns are growing, the inside is filled with a sweet pulp. Near the tip of the thorn the ants make an opening, and another door is made where the thorns unite, and they enter and eat the pulp which is found inside. When they have emptied this queer little pantry of all food there is in it, they have a house as snug and safe as you please.

Glenn: What do they have to eat then?

Ant: The tree that gives them a house already built, also fur-

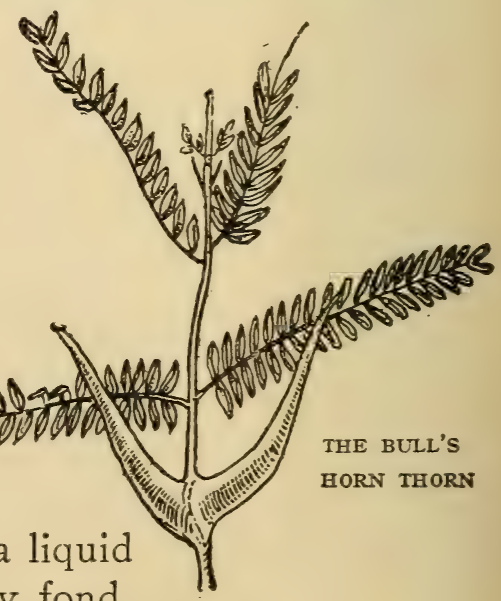
nishes their food.' The leaves secrete a liquid like honey, of which the ants are very fond.

It also bears tiny fruit balls, which under a microscope look like little golden pears. When one is ready to eat, the ants 
bite it off and carry it home. They guard their home tree from leaf-cutting ants, caterpillars, cattle, and men. They have powerful stings, and use them to protect their tree. In very dry seasons when there is no honey-dew on the acacia, and the golden fruit does not grow, they die of hunger; but when the rains come again, the buds yield their food supply, and the ants multiply.

Glenn: Is the white ant, which does much harm by eating wood, paper, and anything that comes in its way, related to you?

Ant: No; it is not an ant at all, its proper name is termite. It belongs to the Neu-rop'te-ra family, that is, the nervewinged insects.

Harold: Harry Stillwell Edwards tells an interesting story about the ingenuity of the black ants.

Iva: Tell it to us, please.

Harold: Tom was a small Negro on a Georgia plantation. The ants numbered probably more than a million. They were all of one family, the little black fellows known to everybody in the South. They were in all parts of the plantation, but their headquarters were in the yard which the rear veranda overlooked. All day long, in good weather, they streamed in and out of their holes, hurrying here, there, and everywhere, always busy. The black ant is as brave as he is tireless, and does not hesitate to attack anything the earth produces, man or beast, fish or fowl, and that with only the weapons nature gave him. That is why Tom became their enemy.

Tom was always barefooted, and so a target for the ants. When he fed the chickens he scratched with first one great toe and then the other the opposite ankle, and rubbed his insteps against his calves, while he called, "Cheek! cheek! ch-e-e-k! cheek! cheek!" When he sat on the ground to polish the table-knives, as was his daily custom, his scanty single 
garment left him exposed to his enemies. It gave hım no relief to smash all the ants in reach; thousands crowded in to take the place of the hundreds. So Tom illustrated the truth of the saying, "Necessity is the mother of invention." $\mathrm{He}$ built fires over the underground cities, poured boiling water down the perpendicular streets, and tried the washerwoman's clothes-paddle. The ants came back every time. Then Tom brought in the hen and her sixteen young chickens, hoping they would help him; but the ants whipped them all out, and killed one little laggard.

One day I saw Tom engaged in a new scheme. He found a little bottle with a broad mouth, and buried it until the mouth was level with the ground. Then he rubbed kerosene over the lip, and poured a little inside. Seeing a broad grin on his black face, I went out to investigate. The ants swarmed about the bottle's mouth, and almost every ant that rushed out on the lip of the bottle fell inside. In less than half a day the bottle was so crammed with ants that the oil was nearly all absorbed. When Tom emptied it, I was puzzled to see as much sand as ant corpses, so when he replaced it and oiled the entrance, I brought a large magnifying-glass to watch them.

Each ant that rushed out upon the lip of the bottle carried with him a grain of sand. They had discovered that the hole was dangerous, and were filling it up. Their momentum, with the weight of the sand grains, sent them into the vial as fast as they came.

I helped Tom to several more broad-mouthed bottles, and the next day he caught three pints of ants and sand. By this time the whole yard seemed panic-stricken, and the little fellows were to be seen meeting on all sides. Tom set out his bottles again in the early morning, but went to town with me to hold the horse. When we reached home, I passed by the battle-ground, and met with a surprise. There were but few 
ants in any of the bottles, and around the mouth of each was a circle of sand half an inch high, the inner slope toward the oil. The next day the bottles were half full of sand, and the magnifying-glass showed me the toilers carrying grains to the top of their fortifications and rolling them down the slope into the bottle.

A day or two after this I found Tom sitting by the bottles and watching his old enemies at work. They had filled the bottles with sand, bored out channels, and were dragging their dead to the surface and down into the underground city. As he watched, Tom scratched his ankles, where already a few wanderers had set their nippers. The bottles were placed in different positions, but the result was the same every time. Now the ingenuity of the little Negro was wonderful, and the reasoning of the ants marvelous; but the most interesting feature was the fact that the plan adopted to fill those bottles was a general one, and began at each place of danger. That seems to argue that the ant has a language of some kind.

\section{Baby in the Tree Top}

"Rock-A-By baby in the tree top;

When the wind blows the cradle will rock;

When the bough bends the cradle will fall,

And down come the baby, cradle, and all."

Iva: I wonder where babies live in the tree tops. See this leaf, Hazel, with a little red berry on it.

Hazel: Not long ago I found an oak leaf with a green apple on it, about as big as a marble.

Glenn: Was it good to eat?

Hazel: I didn't try to eat it.

Harold: Let's see what Iva's berry looks like inside. Ha! here's something alive! Queer house, I should say 
Gall-fy: I am Mrs. Gall-fly, children, and my first name is Cy'nips. That round berry is my child's cradle. The wind

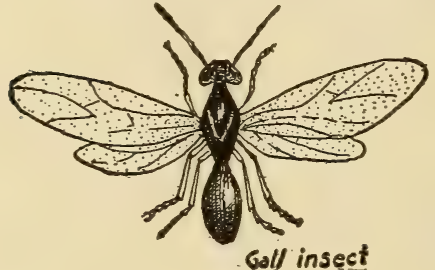

Goll insect blew so hard last night that the leaf was broken off, and down came baby, cradle, and all.

Iva: How could your baby ever get inside? I don't see any door. Cynips: Next spring if you look sharp you may see some of my sisters doing just what I did last spring, humming about among the trees looking for a nice, tender leaf in which to lay an egg. If we gall-flies laid no eggs there would be no oak-galls, or apples, as you call them. We each have an auger hidden in our body with which to bore holes in the oak leaves, and there we leave our eggs. When the egg is laid, the little mother pours over it a drop of liquid, which has a wonderful effect on the leaf. It mixes with its sap and makes a swelling, or gall, which keeps growing till it is as large sometimes as a small apple. Why this liquid should cause this growth on the leaf, the wisest men can not tell. The egg inside the gall grows, too; it grows to be three or four times as large as when it was first left there. After a while the larva is hatched, and finds that its careful mother has its board and lodging all arranged for.

Iva: What does it have to eat?

Cynips: It eats its house. It is about as dry and crumbly as cork, but baby Cynips likes it, and has nothing to do but to eat and grow.

Glenn: Just fancy a baby living inside a ball, and eating its house, and staying there until it grows up.

Harold: How does it ever get out of the gall?

Cynips: It cuts a little round door, as you see in the picture on the next page, and then walks out. It needs no one to teach it how to do this work. 


\section{THE FLY THAT MAKES MARBLES}

Hazel: Is there more than one kind of gall?

Cynips: Thousands; so many they are without number, and new kinds are being found all the time. There are more

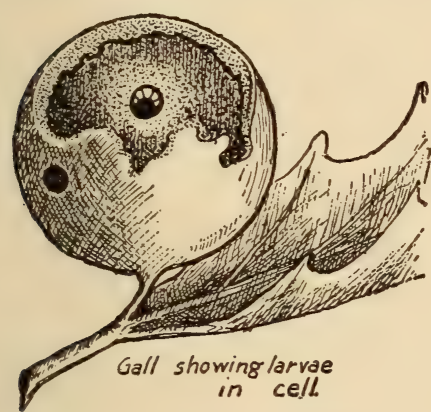

Iva: Is there more than one egg in each gall?

Cynips: Sometimes there are several, each having its own little room. Each insect makes its own kind of gall. Some kinds of oak-galls in Asia and Turkey are used to make ink. A kind of gall found on the shores of the Dead Sea is called apples of Sodom. The galls are as large as apples, and are a lovely color on the outside, but inside they are

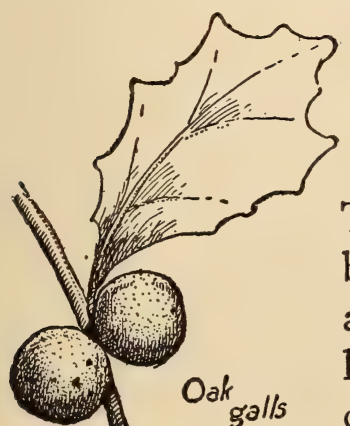
filled with dry dust.

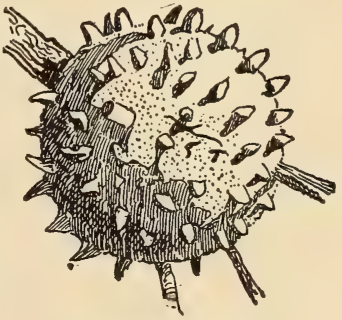

A ROUGH GaLl

Harold: We must see how many kinds of galls we can find next summer.

Cynips: They are found everywhere. The nail gall-mite is so small it can scarcely be seen except with a microscope. Its galls are red and green, and may be found on lime-trees. They are the size of a tack a quarter of an inch high, and there are a large number of mites in each gall. There 
is also a little currant-mite found in England and Scotland which makes the buds grow like wee cabbages. Still another

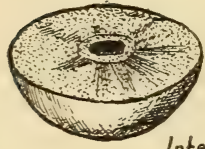

lives under leaves, which it pricks, making bright red or brown blisters, which make the leaves curl up. When thus curled, they form Interior a tent under which thousands of these inof a gall sects find shelter.

Iva: I have seen little red galls on maple leaves. Are they made by gall-flies, too?

Cynips: Yes; they are made by the maple-mite, and when the galls are grown, the leaves look as though they were sprinkled with red beads. The hazel-mite makes the hazel buds grow round, and stops their growth. The elm gall-mite causes little round swellings to come out on the elm leaves.

Iva: Are there other kinds of gallflies?

Cynips: Many, many more. In one gall, called the oak-apple, are large families. Sometimes the brothers live in one house and the

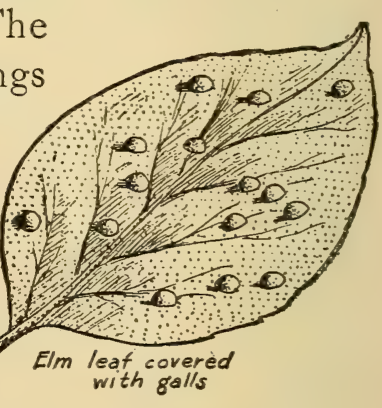
sisters in another. The bramble gall-fly pierces the stems of plants instead of the leaves, and the young larvæ live in the stalk till spring, when they come out as flies. One gall-fly makes marbles. Its galls are about the size of a marble, and are as round and smooth, but not so heavy, and probably would not roll on the ground so well. On the tree they are green, but they turn brown. The insect lives in them through the winter, and comes out through a round door in the spring.

Harold: Next summer we will look for some. I think we must have a little note-book and write down the different things we want to look for, so as not to forget when we go out into the woods and fields. 
Cynips: See how many different kinds of galls you can find. Remember that they are the work of a little insect which God taught how to make a house for her children, each kind in a different way. When you get them all together, they will make a pretty collection.

\section{A STRANGE BOARDING-HOUSE}

Glenn: See this picture, Hazel. What kind of insect do you suppose it is?

Hazel: Let us ask mother.

Mother: That is an ich-neu'mon-fly, but it belongs to the bee and wasp family, instead of to the fly family.

Harold: Then it is a hy-men-op'ter.

Hazel: Is the insect as large as the picture?

Mother: Yes. This is the picture of a fly caught by a boy

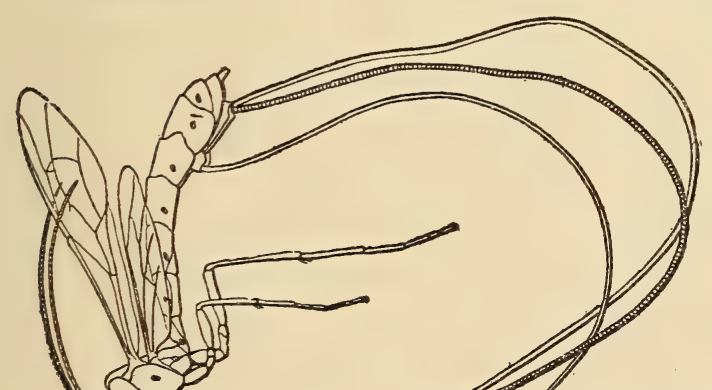
thirteen years old. He found it on one of our common shade-trees. Harold: I should think it had tails enough - three.

Iva: The tails look like ribbons streaming out behind the fly.

Mother: They are neither tails nor ribbons. They are long lances, which enable the insect to reach the larvæ of other insects when laying its eggs. The mother ichneumon lays her eggs in their bodies, or near the eggs of other insects.

Harold: The lances must be several inches long.

Mother: In some ichneumons they are four and one-half inches in length, but some are much shorter. 
Glenn: Can the ichneumon-fly sting?

Mother: No; but it sometimes frightens people by pricking their hands, so they are glad to let it go.

Hazel: Please tell us, mother, why she lays her eggs in the bodies of other insects.

Mother: She does it to provide a boarding-house for her children where they can live on others.

Harold: Do the larvæ of the ichneumons eat other larvæ as food?

Mother: Yes. We shall not find much to admire in this insect, except that it destroys some other insects that would

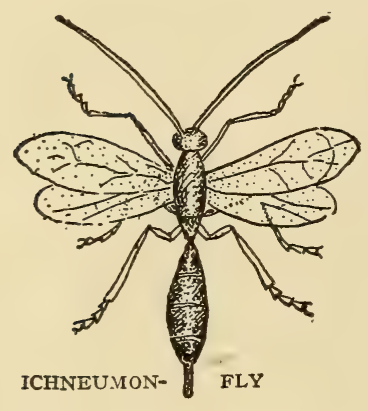
injure our crops. It is deceitful and cowardly; it will linger near where the little carpenter-bee is building her nest, and when the unselfish little mother has filled one of her rooms with food, laid an egg, and gone for material to make a door, the ichneumon sneaks into the nest, lays an egg beside the one laid by Mrs. Bee, and flies away before she comes back. When the little bee mother returns, she shuts up the room and fastens inside a foe that will devour her child as soon as it is alive. Before the baby bee is grown, the ichneumon egg will hatch, and the fat baby bee becomes its food. Another trick the ichneumon has is to lay its eggs on the skin outside, or even inside, the bodies of caterpillars. Here is a picture of the kind that does this way. It is not like the other family of ichneumons, and its lance is very short. Its children like nothing better than to board inside the body of a big, fat caterpillar, but the poor caterpillar has a hard time. The family of maggots inside makes her feel squeamish; so she eats a hearty meal, which only makes her boarders inside grow the faster. Glenn: I should think the caterpillar would die. 
Mother: It does at last. Perhaps some day you will have a large caterpillar which you hope to see change into a beautiful moth or butterfly. But it begins to droop and waste away, and soon you find it covered with little white things that look

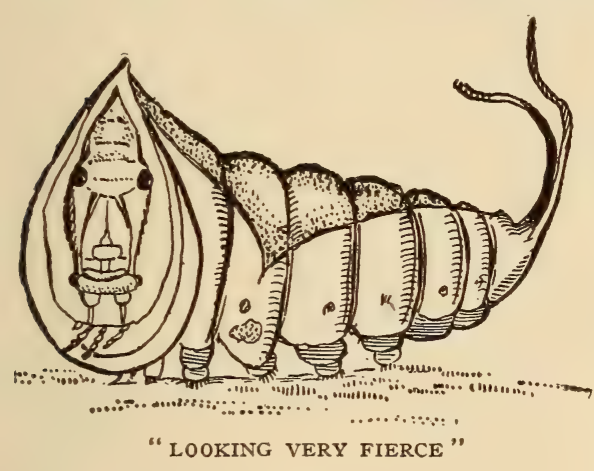

like the tiniest grains of rice standing on end. These are fastened to the skin. Soon after they appear, the caterpillar dies. From those little white grains come green insects like flies, having four wings, and antennæ that keep moving all the time. They are ichneumons which have boarded with the caterpillar during their larval and pupal states. A few caterpillars save themselves by looking very fierce when they hear Mrs. Ichneumon in the air, as a hen ruffles her feathers to protect her brood.

Hazel: Do ichneumons prey on anything but caterpillars?

Mother: There is one that lives on bees, another on spiders, and still other insects are troubled with these parasites.

Glenn: What is a parasite?

Mother: It is a creature that lives at the expense of others, instead of providing for itself.

Harold: Can people be parasites?

Mother: Yes. So never let another do for you that which you are able to do for yourself.

\section{THE FLY WITH A SAW}

Mother: How many wings has the common fly?

Glenn: Two.

Mother: The saw-fly has four. When at rest the wings are separate, but when flying they are hooked together, like the 
wings of wasps and bees, which belong to the same family. The head and thorax of the saw-fly are usually black, and the abdomen striped with black. At the end of the abdomen are two hard, horny flat plates. There are saw-like teeth on one side of these plates, and the other is thick like a carpenter's saw. Can you guess why this is so?

Hazel: To make them strong.

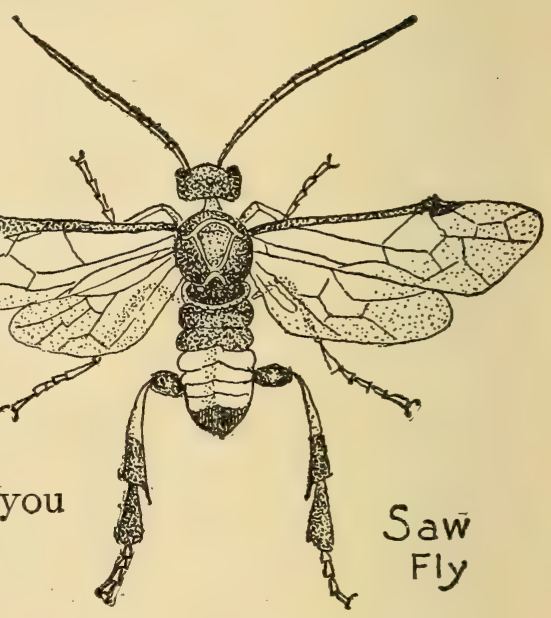

Mother: That is right. To see how perfect they are, we should examine them through a microscope. They are used to make the home of the baby saw-flies. With her saws the mother cuts a groove in a leaf, a twig, or even in solid wood, an egg is placed, and then another groove is sawed, and she keeps at her work until a large number of grooves are made and eggs placed in the nests made for them, and there they are made fast with a glue that the insect carries for that purpose.

Harold: Do the eggs become larvæ?

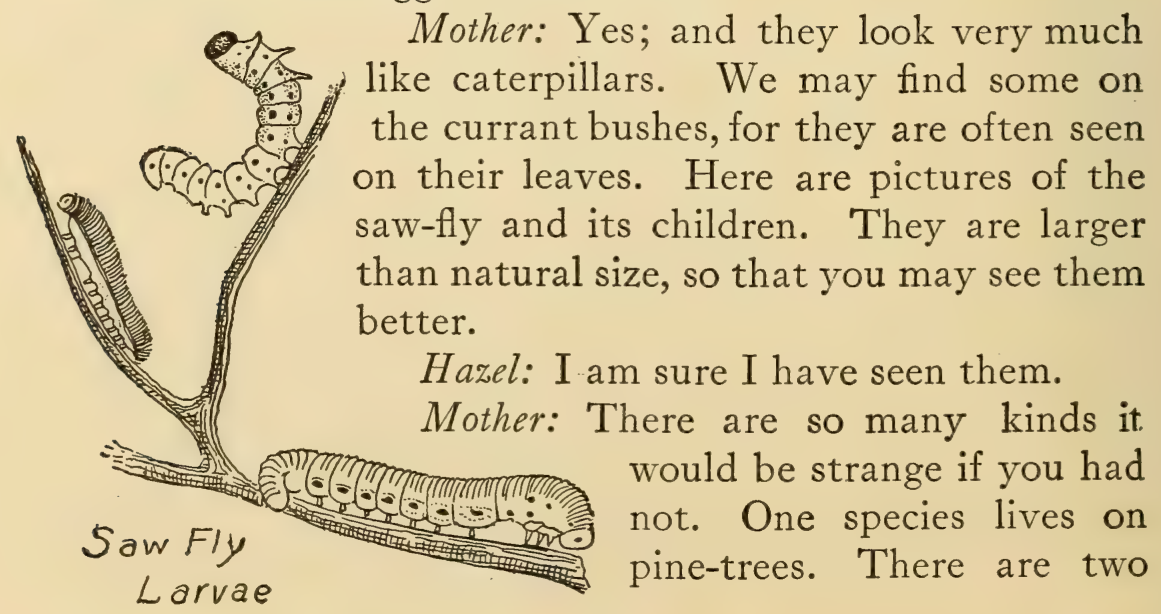


varieties that do great damage. The larvæ of the first are called slug-worms, their bodies being covered with a sticky liquid, used for protection no doubt. They flatten out in the daytime and look like a lump of slime. At night they do much harm to fruit-trees.

Iva: What is the other kind?

Mother: It is called the turnip-fly, or nigger.

Harold: Do saw-flies eat turnips?

Mother: O, no! but the larvæ eat the turnip tops, and they are what do the mischief. Sometimes large fields of turnips are destroyed by them in two or three days. The mother fly lays her eggs on the under side of the leaves, and the eggs grow to three times their original size before they hatch, on the ninth day. When the larvæ are hatched, they are as hungry as bears, and in two minutes they may be seen in a row on the edge of the turnip leaf, eating it, with their tails high in the air. They have a trick of curling up in a ring and falling to the ground if touched.

Hazel: Is this the picture of a saw-fly?

Mother: Yes; it is the one called Si'rex gigas. This saw-fly has an auger instead of a saw, with which she bores into solid

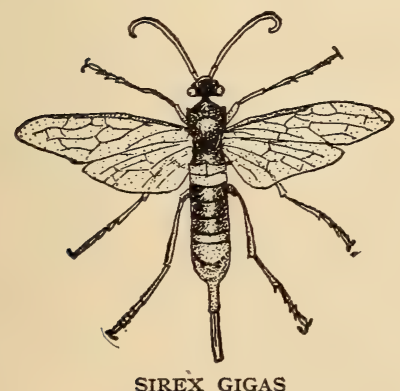

SIREX GIGAS wood. This borer is so strong that if it is bent, it will spring back like a sword of steel. It is sometimes as large as a needle, and an inch long. It looks so dangerous that most people are glad to let Mrs. Sirex alone. She has such strong jaws that she has been known to eat her way through sheets of lead a quarter of an inch thick. The saw-flies form a very large and interesting family of hymenopters. 


\section{ORTHOPTERA}

\section{The Grasshopper}

Iva: I see you, Mr. Green Grasshopper. You look so like that fern stalk I could not find you at first, though I could hear you plainly enough.

Grasshopper: My color protects me from my enemies and helps me to hide away. Do you like my song, Miss Iva?

Iva: O, yes! It must be fine to sing like that. Please tell me how you make such a big noise.

Grasshopper: I cling fast to whatever I am standing on, press my body down hard, and then tremble or shudder all over. The Creator has filled the world with music made by a vast number of insect musicians. There is a large orchestra that fills the air with a low, peaceful, soothing melody.

Hazel: I suppose other things besides insects make music. I

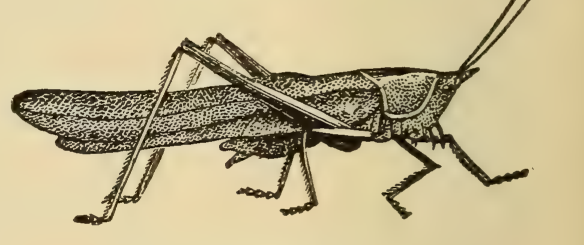

COMMON GRASSHOPPER remember a little stanza of poetry which reads like this:"Do you ever hear, as I hear, 'mid the hubbub of the town, Soft music made by silvery waves upon the quiet shore; Or the laughter of glad winds that rush across the open down To dry the tearful blossoms when an April shower is o'er? Do you ever know, as I know, how these undertones can drown All the strident sounds of labor, and the traffic's ceaseless roar?"

Grasshopper: I suppose the insects that drum in the trees, fiddle in the bushes, and buzz in the air, add to the harmony of the music of nature.

Harold: I think it is all a song of praise to the Creator for 90 
clear sunshine and blue skies. I remember there is a psalm which says:-

'Praise the Lord from the earth,
Ye dragons, and all deeps;
Fire and hail, snow and vapor;
Stormy wind fulfilling his word;
Mountains and all hills;
Fruitful trees and all cedars;
Beasts and all cattle;
Creeping things and flying fowl."

I suppose the creeping things we read of in the Bible mean insects, like bees, grasshoppers, and all the other kinds we see.

Grasshopper: I am glad to unite my song with the rest in praising the God who made us.

Hazel: Were you always a grasshopper, as you are now?

Grasshopper: Unlike most insects, when I was larva and pupa I looked very much like my parents. I was hatched from an egg my mother laid last September. Many eggs laid by grasshoppers are eaten by birds and animals; but, happily for me, the one from which I came escaped that fate. I was at first a tiny baby grasshopper, only I had no wings. Six times I changed my skin, and each time my new skin was larger than the one I had before, as your clothes are made larger each time you have a new suit. When I got my sixth change of dress, I had wings, and felt as proud as a boy with his first pair of trousers. I could then take long jumps, which made me so merry $I$ have been singing ever since.

Harold: How long did it take you to grow as big as you are now?

Grasshopper: After four months I changed from larva to pupa, and it took about one month for my wings to grow, so you see I am now about five months old.

Hazel: To what family do you belong, Mr. Grasshopper? 
Grasshopper: The Or-thop'te-ra, because we have long, narrow, straight wings. The outside pair are used to cover the under ones. These are broad, and fold up like a fan when not in use. We have long, slender horns, or antennæ.

Glenn: I should like to know how you can leap so far. I try to jump some, but believe you could beat me, if our sizes were to be compared.

Grasshopper: You must have noticed my long hind legs. I can not walk very well, because they are so much longer than the others, but I am a champion jumper. When I want to leap, I straighten my long legs, give a spring, and away I go. My wings help, of course, but I am thankful indeed for my long legs, which many times help me to get out of the way of danger.

Harold: What do you eat?

Grasshopper: Nearly all the Or-thop'te-ra family are vegetarians; that is, we eat the leaves and stalks of plants. I bite off wee bits of leaf, which are ground into powder in my gizzard. Since I eat green things, I am made to look like them.

Glenn: Birds have gizzards; insects do not.

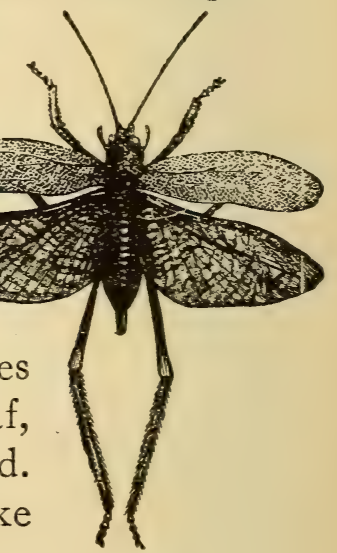

NARROW-LEAVED

GRASSHOPPER

Grasshopper: Mr. Wood says that grasshoppers have gizzards, and he ought to know, for he has studied insects enough. He says my digesting place is larger in one part, and that if it is cut open there may be seen some narrow bands, which, when placed under a microscope, show rows of small teeth, which grind to powder the leaves I eat.

Hazel: Do you have ears?

Grasshopper: My ears are on each side of my body, just back of my hind legs. They are round, and can be seen if my wings are lifted. 
Harold: Do you sing with your mouth?

Grasshopper: I sing with my wings. I rub them together, as you draw a bow across the strings of a fiddle. Sometimes I strike them together, as the man in the band strikes the cymbals, and I tremble all over.

Iva: Where do you live?

Grasshopper: In almost all countries, but we flourish best where it is very warm.

Glenn: Do you have any relatives?

Grasshopper: Plenty of them. There are many kinds of grasshoppers, and also the locust. He is my first cousin, though some people think he is my brother, and can hardly tell us apart. The Or-thop'te-ra family is divided into two classes, one of which have long hind legs like myself, which enable them to make long jumps. To this family belong the locusts, grasshoppers, and crickets.

Harold: How do the other members of your family differ from you?

Grasshopper: They have six legs, adapted to running instead of jumping, and they know how to use them. Cousin Locust can jump farther than any other member of our family.

Hazel: Can he sing?

Grasshopper: Yes; his song is produced by rubbing his legs across his wing-cases, one at a time. His music is louder than mine, for he has a drum on each side of his body, filled with air and covered with thin skin. Here he comes. I think he will be glad to tell vou about his travels, for he has been in all parts of the world.

\section{THE LOCUST}

Harold: Glad to see you, Mr. Locust. Will you please tell us about yourself and your travels?

Locust: My name comes from a word which means burnt 
place. Perhaps you have already noticed that my horns are not so long as Cousin Grasshopper's. My body is more stout. There is not very much difference between us, and one is often taken for the other. I am sure, however, that people like cousin better than me, for locusts are known as crop destroyers; but Cousin Grasshopper sometimes does considerable damage.

Iva: What do baby locusts look like?

Locust: Some like grasshoppers. When they are about a month old, you may find them on bushes and trees wriggling and twisting about until their skin bursts open. First you see a pair of bright"eyes, then a head, and after that the whole body. Locusts have gauzy wings, and are greenish brown in color. Our

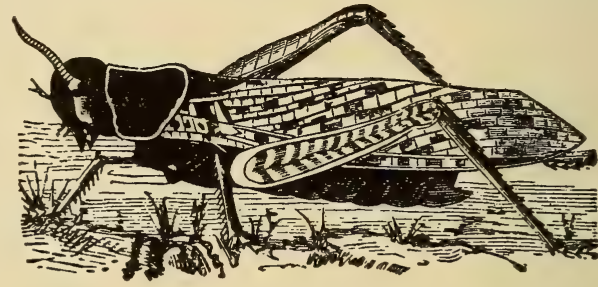

EASTERN LOCUST wings sometimes serve as sails when we cross the water.

Harold: I have heard that locusts form themselves into armies.

Locust: After they are hatched, they gather together like soldiers going to war.

Hazel: I read in the Bible that "the locusts have no king, yet they go forth all of them by bands."

Locust: That is true. They go straight ahead, and nothing can break their ranks. If they come to a building or anything else that stands in their way, they go over it and proceed on their journey.

Glenn: Mother told us that you do great damage in hot countries, and even in temperate climates.

Harold: I believe there is a Bible verse that says that they are "like the noise of a flame of fire that devoureth the stubble," and it also says that "the land is as the garden of Eden before them, and behind them a desolate wilderness." 
Hazel: I remember reading that the locusts came as a plague in the land of Egypt. "And the locusts went up over all the land of Egypt, and rested on all the coasts of Egypt: ... they covered the face of the whole earth, so that the land was darkened; and they did eat every herb of the land, and all the fruit of the trees which the hail had left; and there re-

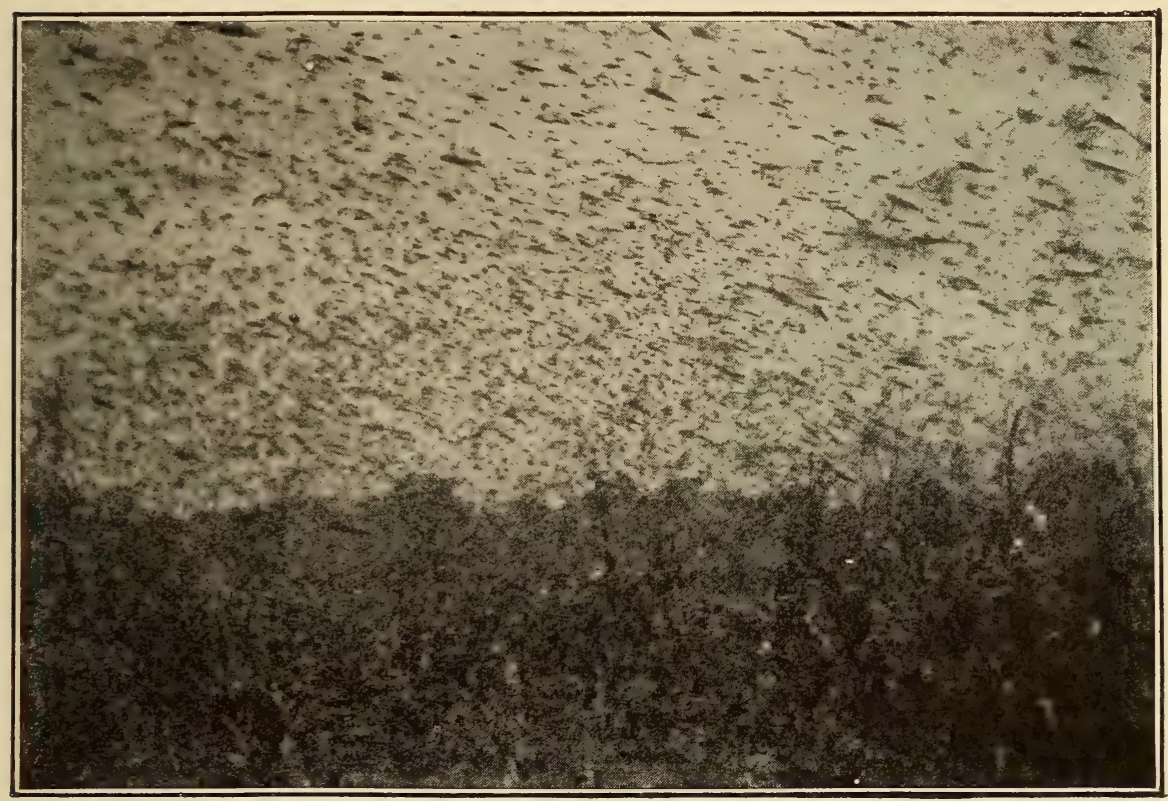

From a photograph

STORM OF LOCUSTS IN AFRICA.

mained not any green thing in the trees, or in the herbs of the field, through all the land of Egypt."

Harold: It must have looked then as though a fire had swept over the country.

Locust: Even now in some parts of the world, as India, Africa, and some countries of Europe, as well as in parts of America, we are counted pests. We fly in bands, or swarms. I suppose the reason we do so much harm is because there are so many of us. 
Ifarold: I read that a swarm of locusts appears like a cloud of dense smoke, and when they fall they come as thick as raindrops or snowflakes in a heavy storm. The sun can not be seen and the trees cast no shadow.

\section{Iva: How can you fly so far?}

Locust: We fill our bodies with air, and the wind helps us along. We travel from three to twenty miles an hour. From Asia we go to Europe, a distance of four or five hundred miles. In North America we have been known to travel a thousand miles. We can go five hundred miles without stopping, if conditions are favorable. We have been known to cross large bodies of water.

Glenn: Do you travel at night?

Locust: Sometimes, if the weather is warm, and the wind comes from a direction that will help us. But we usually begin a journey as soon as the dew is off, and settle down as night approaches.

Iva: Why do you go on such journeys?

Locust: To get food. We are always hungry, and I have such a multitude of brothers and sisters, uncles, aunts, and cousins, and other relatives, that it takes a great quantity to feed all of us. Sometimes we look like stormy clouds, the sky is black with us, and we cover the ground when we fall. The Bible speaks of our coming and the noise we make as "the noise of chariots on the tops of the mountains." Others have likened this noise to that made by a mighty waterfall. When we light in the trees, the branches break under our weight. We eat every green thing, and even gnaw the roots of plants in the ground. Sometimes we can not find enough to satisfy us, and die of hunger. Then our decaying bodies make the people ill. Ships crossing the Mediterranean Sea sometimes have their sails covered with swarms of locusts.

Harold: I suppose people try to get rid of you? 


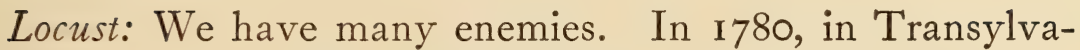
nia, the army was called out to fight us. The soldiers gathered my unfortunate relatives in sacks; but, though they crushed, burned, and buried them, still there seemed to be as many as before. A cold wind caused them to disappear, but they came back the next spring as hungry as ever, and the people said they ruined the country.

Hazel: I read that travelers in Central Africa found the surface of rivers so covered with the bodies of locusts that the water could not be seen.

Harold: There must be millions of them; for some travelers say they have seen locusts piled on the ground two feet deep as far as the eye could reach.

Glenn: I have read that very strange things are done to drive them out of the country. In Sudan the Negroes yell at them; in Hungary cannon are fired to frighten them away; in the middle ages monks formed processions, went into the fields, and cursed the locusts. Some of them were caught and told to leave the country in three hours and go to sea, and that the birds, animals, and tempests would destroy them if they remained; then they were let go, that they might tell the rest.

Hazel: The Arabs write a prayer on paper, fasten it to a reed, and place it in a field of wheat. Others write a verse of the Koran on the wings of four locusts, and let them fly away. It is believed that this will cause them to leave. Is it true that some people eat locusts?

Locust: It is; in some countries we are salted and dried, and in Asia and Africa we are sold for food.

Harold: A gentleman riding on horseback on the island of Mitylene toward the end of May, heard a sharp, pattering noise like rain-drops falling on hard ground. Looking closely, he saw a countless multitude of tiny black insects not much 
larger than the head of a pin. He could see them hopping and springing about under the feet of his horse, and, though he rode many miles, yet they still pattered down. They had just hatched from eggs laid the year before. Three days before not a locust was to be seen. Great kettles of boiling water were placed by the roadside, and all the people in the country went out hunting locusts. They caught enough in one day within less than five square miles to weigh twenty-three thousand pounds. A child of six years. could gather as many as a man.

Hazel: How could they catch so many?

Harold: They used sacks and brooms. The empty sack was placed open on the ground, and the locusts were swept into it as fast as one could move his arms. The people were paid half a cent a pound for all they gathered, and some earned fifty or seventy-five cents a day, or, in English money, two or three shillings. The sacks were thrust into the kettles of boiling water, and then the insects thrown into the river. The gentleman said the locusts had been in Mitylene for three years before the year in which he saw them, and that they generally went away the fourth year. Ten days from the time they first appeared they had grown to be large insects, and were as hungry as ever.

Glenn: Was there more than one kind?

Harold: Yes, several, and some were much larger than others. The hind legs of the largest kind were nearly three inches long, twice the length of their bodies. They could jump about twelve or fifteen feet. They had long sharp claws, and when they took hold of an object they would not let go. They had armor on their heads and shoulders.

Iva: What color were they?

Harold: Some were bright green like the grasshopper; $\mathrm{o}$ hers had brown backs and were yellow underneath; while 
others were speckled, and still others were nearly black and had very long wings. One kind had long feelers, nearly twice the length of its body, and big tusks with saws inside, and its bite was strong enough to bend a pin. It had horny eyes, which it could not shut, and its head was some like that of a lobster. It had scales on its body, and when it moved they creaked like our new shoes.

Iva: I am glad there are none of that kind in this country. Harold: I think we may well be glad, for they would not leave us much to eat. All these different kinds of locusts made a swarm of millions and billions. It would be as easy to count the flakes of a snow-storm or the sand by the sea as to count their number. They got into the food; they ate holes in the bedding; they were in pockets; they crawled in the hair. One could not take a step without treading on them, and they hopped onto the food a person was putting into his mouth. They ate clothing as one walked about, and ate the soles off the shoes, and the clothes hanging in the wardrobe. They ate the hair off the heads of women. Everywhere families might be seen wailing over the ruin wrought. There was no way to protect persons or crops from their ravages. One man had a little garden in which he took great pride. At first he kept fires all around it to keep the insects from crawling in. When they could fly, he fired guns to drive them away. He turned a garden-engine on them; and then he buried them. But in spite of all his efforts every green thing was taken.

Glenn: How long did they stay?

Harold: About three weeks. A great wind came up, and they were swept into the sea and drowned. For many days afterward one could not walk on the shore or bathe in the water because of the stench arising from their decaying bodies. The great Mediterranean Sea seemed to be covered with a crust of locusts, as far as one could see. 
100 Friends and Foes in Field and Forest

Hazel: I wonder where our locust has gone while we have been talking.

Locust: I am still near by, and am glad to say that I am not the kind of which you have been hearing.

Glenn: Do you have any other relatives besides the grasshopper?

Locust: Quite a number. Those I am best acquainted with are the crickets, the mantises, and the cockroaches.

\section{Crickets}

Cricket: Good evening, children. I hope you are enjoying the concert; there is to be one every evening while summer lasts.

Glenn: Could you stop your part long enough to tell us your history, and that of some of your relatives?

Cricket: With pleasure, if you care to listen. I came from an egg which my mother placed in a crack in the ground. I have two or three hundred brothers and sisters, so you see there are enough of us to make merry. We remained larvæ all winter, and this summer we grew into full-grown crickets.

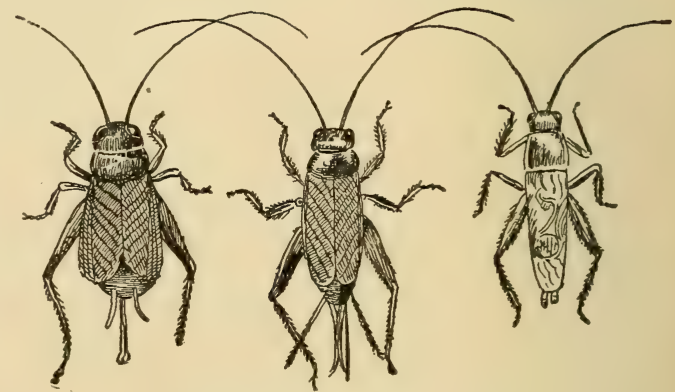

HOUSE- AND FIELD-CRICKETS

Iva: What a large family! Did you all live together?

Cricket: O, no; some of us found our way to a large stone, and for a time we lived very pleasantly together, but as we got older we grew cross and quarrelsome; each of us wanted the best things, and at last we grew so selfish that we could not be together two minutes without kicking, biting, and quarreling with one another. At last each of us went away by himself to 
make a home of his own. You found me here by my front door.

Hazel: I do not see any door nor any house.

Cricket: This hole in the ground is my house. I do not dig straight down as you dig a well, but in a slanting direction, to keep out the rain. In my pantry I have a good supply of seeds, fruit, and grass, which I expect to use as food.

Iva: Will you let us take a peep inside?

Cricket: O, no! I am greatly frightened if anybody comes near, and while taking part in the concert I always stand near the door, so I can go in backward if necessary. When I hear any one coming, I stop my music till he has passed by.

Glenn: I don't believe the grasshopper lays up any food, and I think he is a cousin of yours. I once read that an ant and a grasshopper lived near each other, and while the ant worked very hard storing food for winter, the grasshopper spent his time swinging on the tall ferns or playing his fiddle. When winter came, he went to the ant and begged for some food. "What were you doing all summer?" asked the ant. "I played and sang," said the grasshopper. "Go, then," replied the ant, "and dance the winter away."

Harold: There is a verse in the Bible that says, "The sluggard will not plow by reason of the cold; therefore shall he beg in harvest, and have nothing."

Cricket: I am sorry my cousin is not more sensible; but have you ever heard of the mole-cricket?

Harold: I have seen a picture of one and its house. Please tell us about it.

Cricket: It lives under the ground like the mole. It has finger-like spades on its fore legs, with which it digs in the earth. It burrows out rooms in the ground, leaving one especially as a nursery for its children. This room is about three inches long and an inch high. 
Iva: Does it chirp like other crickets?

Cricket: Yes; that is our way of calling to our mates.

Glenn: I put a straw down the hole of a cricket one day, and the little fellow grabbed it and hung on till I drew him out.

Cricket: It makes us very angry to have anything stuck through our doorway.

Hazel: Some crickets live in people's houses.

Cricket: We like to be

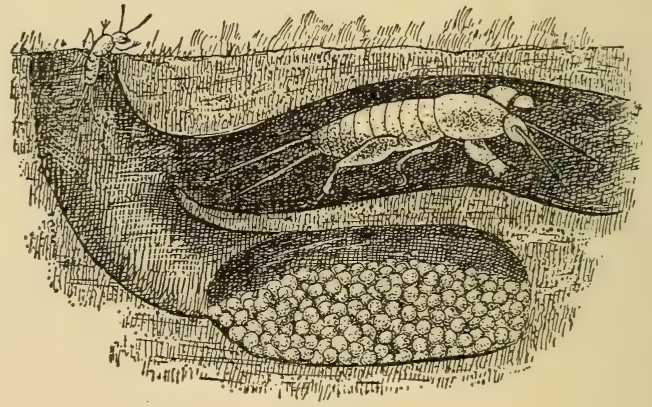

NEST OF THE MOLE-CRICKET warm and cozy, so a crack near the stove or in the chimneycorner is exactly to our taste. If the house is warm enough, we stay about all winter and pay our rent by making merry music for the people the year round.

Iva: How can you make such a big noise, when you are so little?

Cricket: We use our wing-cases, rubbing the edges together briskly.

Hazel: I have heard that you do much mischief by eating woolen things, especially when they are wet.

Cricket: We do very little harm, and hardly ever eat clothing. The reason we like wet things is because we are thirsty and do not know where to get a drink.

Harold: What do you eat?

Cricket: I like fresh, tender grass as well as anything. The house-cricket likes some of the things you eat, such as bread, sugar, and some kinds of fruit. As a family we are all hard drinkers, but never take anything stronger than water. A sparkling dewdrop just suits me, and I am sure no better or sweeter drink was ever made than pure, cold water. I am 
always thirsty, and must have plenty of water to drink or I should die.

Glenn: What shall you do when winter comes?

Cricket: I shall shut myself up in some snug place where I shall not freeze to death, and there sleep all winter.

Iva: What shall you have to eat?

Cricket: I shall not eat anything. When I awake from my long sleep, I am ready to eat and drink enough to make up for lost time.

Hazel: I shall repeat a little rhyme for you:-

"Old Dame Hickett

Had a wonderful cricket

That lived in a hole by the fender.

And when he came out,

He would dance all about

On his hind legs so long and so slender."

Cricket: If you ever go to the Smithsonian museum in Washington, D. C., you may there see a cricket called the Idaho devil. It is almost black. There are so many of them in some of the Western States that one can hardly step at all without crushing them.

Glenn: I suppose there are crickets everywhere.

Cricket: Even in Mammoth Cave, Kentucky, there are some that live far below the top of the ground. They have very long legs and horns, but no ears and no musical organs, so they are perfectly quiet. 


\section{The Cricket}

The cricket lives in the cold, cold ground At the foot of an old oak-tree, And all through the frosty autumn night $A$ merry song sings he.

Then he whistles a clear and happy tune, By the gentle light of the silver moon.

The winds may moan with a hollow tone Through the leaves of the rustling tree; The clouds may fly across the blue sky, The flowers may droop, and the brook may sigh, But not in the least cares he. He whistles a clear and happy tune, By the gentle light of the silver moon, All through the frosty autumn night, And not in the least cares he.

There's a tiny cricket within my heart, And a pieasant song sings he;

He sings of the kindness and goodness of God, Which he daily shows to me.

Let the cricket whistle loud and clear,

Never drive him away with a tear;

There's darkness enough on the earth, even now, $W$ ithout the gloom of a frowning brow.

Cheer up the heart that is clouded in night;

Tell it, in words of love,

Of hope on earth, and a land all bright -

The land of life and love;

And never fret when you can not get

Just what you want while you travel here.

- Selected. 


\section{A Little Hypocrite}

Mother: Last summer when I was in Virginia, I noticed a strange insect in the roadway, and on stooping down to look

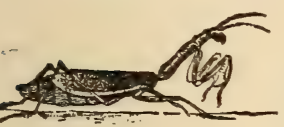

mantis. at it more closely I saw it was a mantis. I had seen its picture in books, and it looked exactly like one I shall show you, and this was its size. When I touched it with a stick, it held up its fore legs as this one is doing.

Harold: Do mantises eat all green things, as the locusts?

Mother: No, they eat insects. You see in this other picture the mantis has caught a fly. It will sit for hours on a plant without moving, and so deceive its victims, for it is about the color of the leaves.

Iva: Does it keep its fore legs raised while it is waiting to catch a fly?

Mother: Yes, and that pious attitude has given it many different names, such as saint, preacher, suppliant, and diviner. Its raising its long front legs like arms toward heaven has led many to believe that the mantis can foretell future events, and that if a child were lost and asked its way, the mantis would point the direction by stretching out one of its long legs. Some think it is praying while sitting that way, and in Central Africa the natives worship it. But watch it as a fly comes near. You will see it steal-

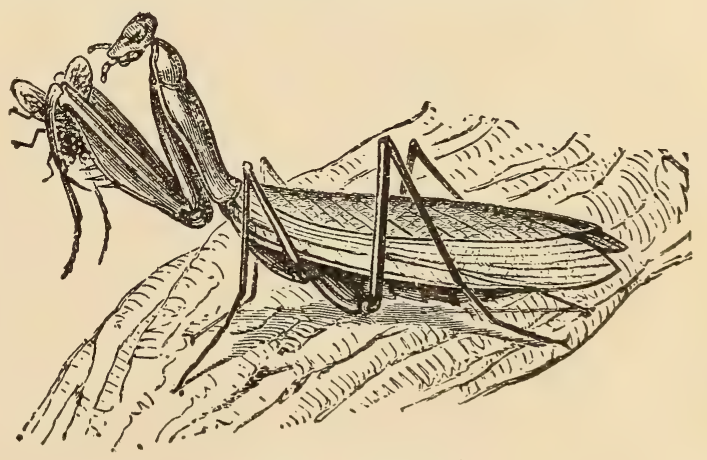

MANTIS WITH FLY ing toward the fly as a cat toward a mouse, and quick as lightning the fly is seized between the legs, and soon devoured. Some people call it the praying-mantis, but others think it 
should be called the preying-mantis. Do you see the difference?

Harold: Yes, the spelling of the words.

Iva: I think it looks wicked. I'm glad it doesn't live here.

Mother: Where the mantises are found, the boys think it sport to drive them about with strings tied to their long necks. They are sometimes called devil's horses and rearhorses. They are very quarrelsome, and will fight fiercely with one another.

Glenn: They try to make others believe they are better than they really are.

Harold: People who do that are called hypocrites.

Mother: Their name means sorcerer, and was given them, I suppose, because they are deceivers.

Harold: They seem to be among insects what lions and tigers are among animals.

Mother: They are even more cruel than these animals, for they will kill and eat one another as quickly as they will eat a fly. The baby mantises hurry away to hide from the older members of the family as soon as they are hatched.

Hazel: Are they as cruel as their parents?

Mother: Yes, they do the very same things. Sometimes the mother mantis, after playing a long time with her mate, will pounce upon him and kill him.

Glenn: Then she is even worse than a hypocrite.

Mother: There are some good things about the mantis, even though it has so many bad traits. It is useful, because it devours many bugs, flies, and caterpillars that destroy our gardens and orchards. Some gardeners gather mantis's eggs from wild lands, and place them where, when hatched, they will protect the plants and trees.

Iva: How can one gather such little eggs?

Mother: They are fastened together in small masses, or nests, about an inch long and a third of an inch wide. The 
mother ties them together with a kind of tough silk which keeps them in place, so they can be easily fastened to tree, bush, or vine.

Harold: Is there more than one kind of mantis?

Mother: O, yes! in Africa there is one called Em-pu'sa, which has horns dented like a comb, and cuffs for its arms, and a flounce on its robe.

Hazel: I have heard that some mantises look almost like flowers. Is that true?

Mother: Yes; in India and Africa there are some that appear like the most beautiful blossoms, the very flowers that

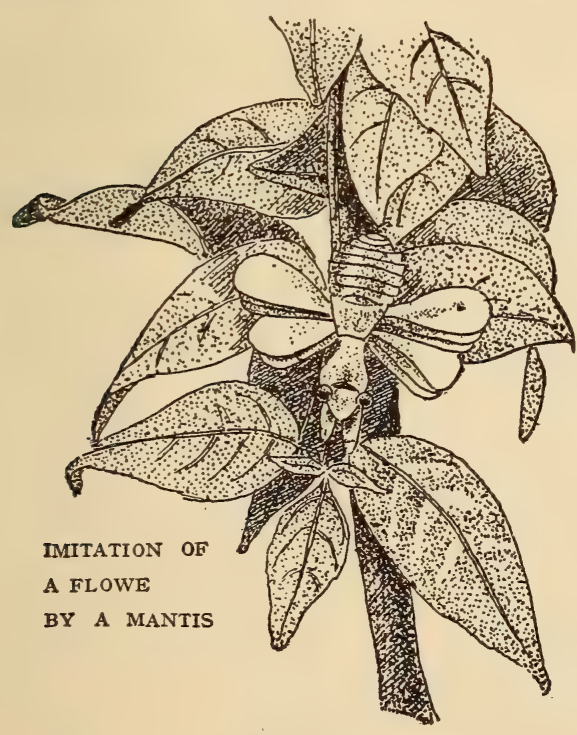
some insects value as food. When a butterfly or other insect lights to take a meal of honey, that which seems to be a beautiful flower greedily seizes it; it is crushed to death, and then devoured. It is like some kinds of sin that appear innocent and pleasant, but deceive and destroy. I hope you will remember the lesson to be learned from this insect, and look out lest you be caught in a snare.

Glenn: What is this picture, mother?

Mother: It is a mantis found in India and Java that looks like a flower in form, color, and position. The thighs of four of its legs look like the petals of a flower, and the insect seats itself with two spread out on each side, and with its fore legs folded out of sight.

Iva: I see a pair of shiny eyes that are watching. 
Mother: I see them, too. There is a mantis in India of a pale violet color, and it hangs head downward among the green leaves, where it sways about like a flower touched by a gentle breeze. It looks like a blossom, and many an unlucky insect flies into the arms of the betrayer. This should teach us that all pretty things are not good and true.

Hazel: Is the katydid a relative of the grasshopper and cricket?

Mother: Yes; and we must not forget it while getting acquainted with the insects in this family. Here is its picture.

Glenn: What long feelers it has, and it keeps them over its back instead of straight ahead.

Mother: It is very careful of them, and I suppose can move them about in different directions if it wishes to do so. Some katydids have heads that look like that of a horse. They are really pretty and graceful insects.

Iva: What color are they?

Mother: The same as the leaves among which they live.

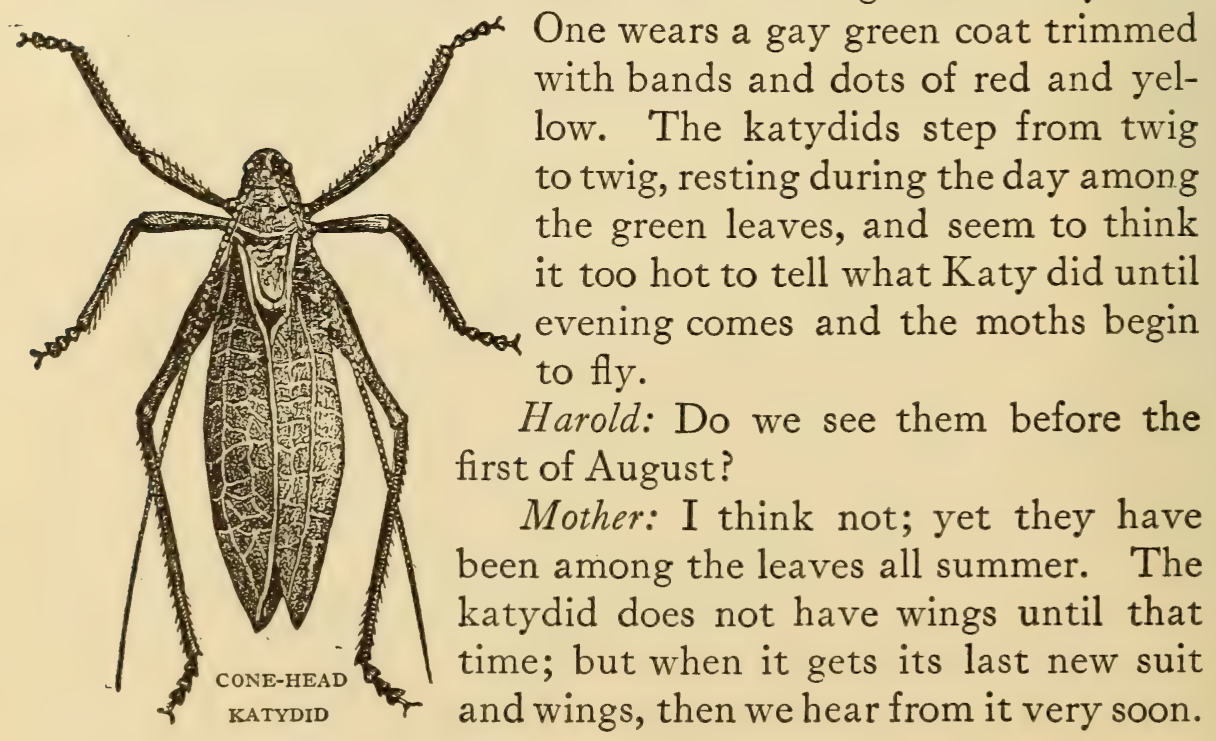


Glenn: How can the katydid talk and say, "Katy did, Katy did"?

Hazel: Some of them say, "Katy didn't, Katy didn't," as well as, "Katy did, Katy did." Who is Katy, anyway, and what is it that she did or didn't do?

Mother: That is a secret the katydids have never told. Perhaps Katy is Mrs. Katydid; for she never talks, and it may be that her mate likes to tell what she did.

Iva: And perhaps his neighbors like to say that "Katy didn't."

Mother: When I was in Arkansas camping out, the katydids filled the air with their chorus as soon as evening came, saying, "Katy did, Katy did, Katy did, she did, she did," and others seemed to say, "She didn't, she didn't." Their voices grew louder and louder, till they seemed to stop all at once, only to begin saying the same words over and over again.

Harold: How do the katydids make such a noise?

Mother: Near where the wings join the body there is a thin membrane which seems something like thin glass. This membrane is in a rough frame, and when the katydid opens and shuts its wing-covers, the frames rub together, and that makes the sound.

Hazel: I think the katydids look like grasshoppers.

Mother: There is a family likeness. They lay their eggs under the grass, and they lie buried in the ground until spring. The baby katydids look like tiny grasshoppers without wings. They hop about during the summer until their wings are grown, and then join the orchestra, and make music during the evenings until cold
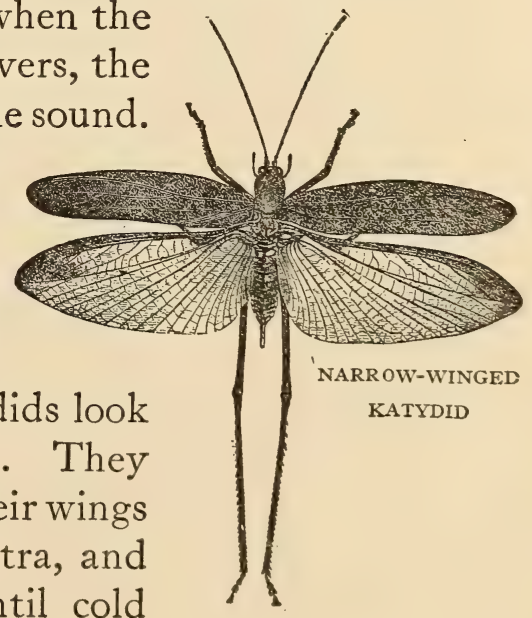
weather comes. It is the broad-winged katydid that makes the sound that gives it its name.

Glenn: Are there other katydids?

Mother: Yes, there are many members of this family. The narrow-winged katydid calls to his mate in a very gentle tone, "Zeep, zeep, zeep," and she answers with a chirp.

Iva: I wish I knew what they mean by saying, "Katy did" and "Katy didn't."

Mother: The cone-head katydid makes such a sharp, shrill noise that it makes a person feel like stopping his ears. The voices of some of this family of insects are not so loud and tiresome as others. I think it must have been of the more gentle-voiced ones that the poet said:-

"I love to hear thine earnest voice Wherever thou art hid,

Thou testy little dogmatist, Thou pretty katydid.

Thou mindest me of gentlefolks, Old gentlefolks are they;

Thou say'st an undisputed thing In such a solemn way."

\section{LIVING STICKS AND LEAVES}

Mother: There is a family of orthopters which is very odd. You have heard how an insect can look like a flower, but you would hardly expect one to appear like a dry stick. But look at this picture. If you look closely, I think you can see that one of the branches is what is called a stick-insect. Sometimes it is called a walking-stick.

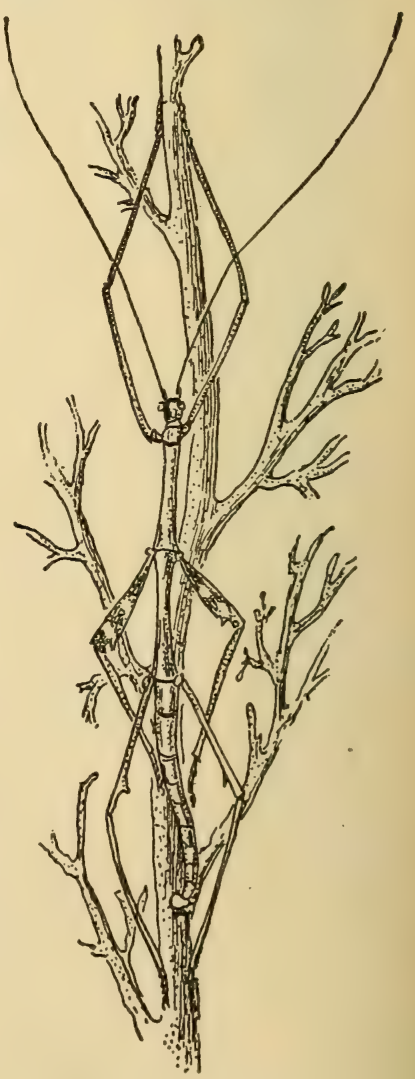

THE WALKING-STICK 
Harold: You don't mean to say that anything that looks like that is alive, do you?

Mother: Part of it is. Do you not see the long, straight

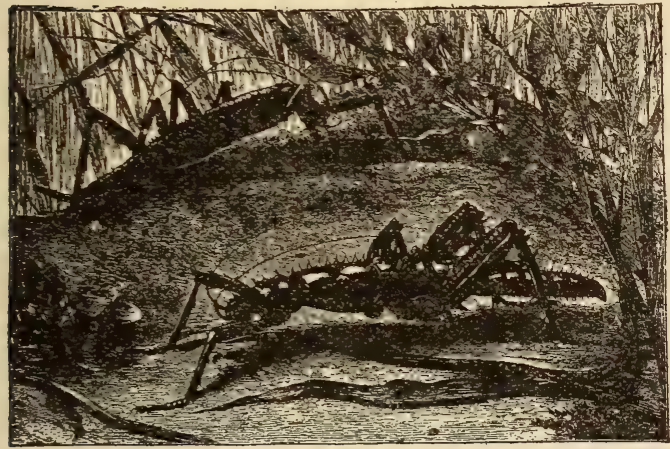

STICK-INSECT FROM SOLOMON ISLANDS (ABOUT ONETHIRD NATURAL SIZE) body, the longlegs, much like a stick, to be sure?

Iva: Where do the stick-insects live?

Mother: In South America, Asia, Africa, and New Holland. In this family we shall find the largest, perhaps I should say the longest, insects in the world.

Hazel: Auntie saw a

stick-insect a foot long in the British Museum.

Mother: Yes, they are found as long as that, and as thick as one's finger. Their family name is Phas'ma. Sometimes they are called phantoms, devil's horses, and animated sticks. I suppose their long, slender bodies are the cause of their having such peculiar names. Their color is like the wood, but if you watch, you will soon see the shorter twigs begin to move, and lo! your stick is walking away. There is one member of the family that looks as though it were covered with moss. In Borneo these insects are found looking exactly like sticks overgrown with moss.

Harold: Do they do any harm?

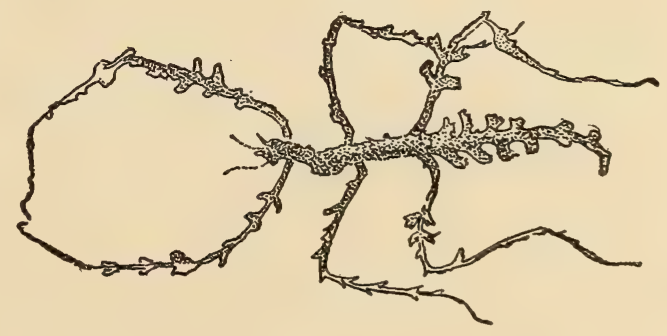

MOSS-INSECT

Mother: No, they eat but little and molest nobody. If any one comes near, they gently walk away. It is said that some 
eject a bad-smelling fluid when touched, but that is their only means of protection, except their form and color. They like to stretch themselves out in the sun. The best-looking members of this family are found in Tasmania.

Glenn: Now that we know there are insects like sticks and moss, we might expect to hear next that some look like leaves.

Mother: And there are some of that kind. Look at this picture of the leaf-insect, and see if you would not be puzzled if it had lighted on a leafy branch, to tell which was insect and which were leaves. Its color is bright green; it has yellow markings like a leaf, and its whole appearance is as leaf-like as possible. Then there are walking leaf-insects that look like dead, withered leaves. They are found on dry wood in Sumatra and

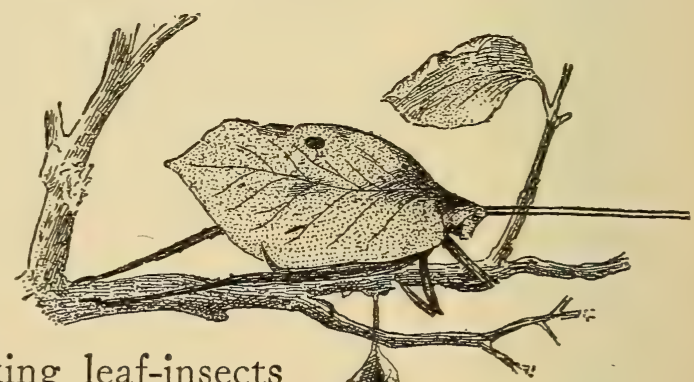

WALKING I.EAFINSECT India. They never light on green bushes or trees, but only on those having dry, dead leaves. Their form and color protect them from birds and other creatures that would devour them. It is vain to search for them, for one may look at the very spot where they light and see nothing at all; but suddenly the dead leaf at which one is looking darts out, then lights, and is a leaf again.

Hazel: I suppose God made them that way to protect and keep them alive.

Mother: I have read that there is a kind of beetle that looks like withered, crumpled leaves whose edges have been eaten off, and that some bugs appear like the skeletons of leaves. This all shows how the Creator planned to protect these little creatures, and it is very interesting to see them and learn their ways. 


\section{NEUROPTERA}

\section{The Dragon-Fly}

Hazel: What was that going through the air so quickly? Harold: Here is one. Will you please tell us your name? Glenn: I believe you are called darning-needle. Your body is long and slender enough to give you that name.

Dragon-fly: $\mathrm{Th}$ at is only a nickname; I am also known as horsestinger and spindle, though I neither spin nor sting. My real name is dragon-fly, but I am not a dragon nor a fly. I like best the name given me by the French people. They call me "little lady," and the Germans call me "maiden of the water."

Harold: Do you belong to the Dip'te-ra family?

$$
\text { Dragon-fly: No. }
$$

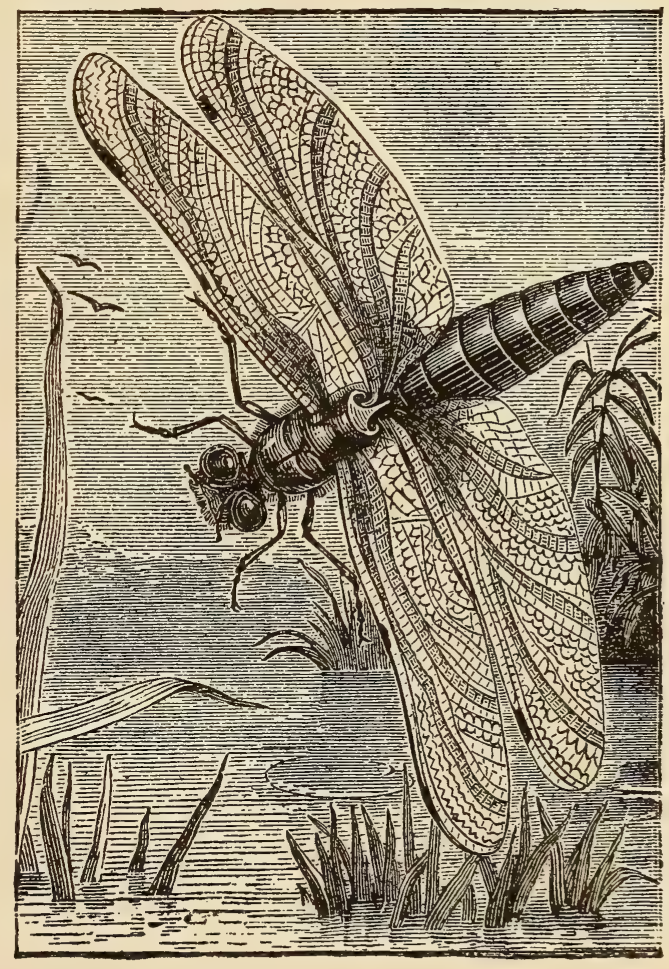

DRAGON-FLY

I have four gauzy wings that look like finest lace. That is because there are fine lines, or tubes, all over them covered with membrane above and beneath. They look like lace stretched on a frame. For this reason I belong to the Neu-rop'te-ra family, which means nerve-winged. 
Iva: Then the white ants are your cousins, for they belong to that family.

Dragon-fly: You mean the termites. Yes, we are cousins, but not at all alike.

Glenn: Do you have as many eyes as the house-fly?

Dragon-fy: I have over twelve thousand in one on each side of my head, and three more on my forehead.

Harold: As the light flashes in your eyes, it makes them look like dewdrops in the sunshine. Do you fold your wings when not using them?

Dragon-fy: No; they always stand out straight, as you see them now. In the sunlight they reflect all the tints of the rainbow.

Iva: Can you fly fast?

Dragon-fy: I think so. Our wings are very strong, and we never get tired. A man once watched a dragon-fly pursued by a swallow, and though that bird is very swift in flight, the dragon-fly kept ahead of him. I have heard that one of my brothers lighted on a ship when the nearest land was five hundred miles away.

Harold: I think men would better take you as a model for the air-ships they are inventing.

Dragon-fly: Did you notice my pretty red dress?

Hazel: It is beautiful. Do all dragon-flies wear red?

Dragon-fly: No; some wear bright blue or green; but we are always neat and well dressed, no matter what the color.

Harold: What a strange mouth you have!

Dragon-fy: My jaws move up and down like yours, so there is nothing strange about that, and I do not suck my food through a tube as some other insects do.

Harold: No; but your thin lips move with your jaws in a very queer way. What do you eat?

Dragon-fly: All kinds of insects that are small enough for 
me to capture. I am sometimes called the mosquito-hawk, because I devour so many of these troublesome pests. Sometimes children and grown people, too, are afraid of me, though I can not see why, for I can not harm them. Just let me into your room, please, and I will soon eat up the flies and mosquitoes. I have a good appetite.

Iva: Where is your home?

Dragon-fly: I like a dark swamp or a lonely pond best, for there I find good hunting-grounds.

Glenn: Can you sting?

Dragon-fly: Not at all. I suppose the habit of curling my body up and down leads some to believe I have a powerful sting and am waiting for a chance to use it. Perhaps that is what made them give me the name horse-stinger.

Glenn: Have you been flying around hunting flies and mosquitoes all your life?

Dragon-fly: The most of my time I have lived in the water.

Iva: Didn't your wings get wet when you lived there?

Dragon-fly: I didn't have any wings then. My mother dropped her eggs into the water as she was darting about over the pond. They were water-proof and sank to the bottom. It did not take long for them to hatch, and the first thing I remember is that I was lying in a mud cradle feeling very hungry. I began stealing about, slowly and quietly, as a cat does when hunting a mouse, and soon a young tadpole came within reach.

Hazel: Did you succeed in catching the tadpole?

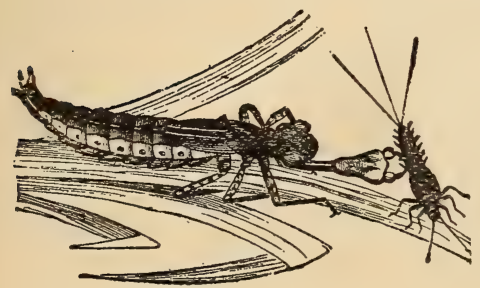

Dragon-fly: To be sure I did. My jaws were hidden by a mask which covered the lower part of my face. Here is my picture taken just as I caught a water-sprite, though he was captured before he could wink. 
Glenn: Is that your mask that is just touching the insect? Dragon-fly: Yes, and it was very useful to me. It worked like a spring. If you look closely, you will see that this mask was my under lip, and it folded up in several parts, and was fastened to a rod with a hinge. Its edges have sharp teeth, and at the end are two pinchers. The mask served me as an under lip, as an arm, as a hook to catch my prey, and as a face covering. As soon as an insect was seized with it, the mask carried it to my jaws, and I began my meal. When I had finished, it covered my face so that nothing could be seen but my eyes, and I went on looking for more food, for I was always hungry. Thus I saved you a great deal of trouble; for the larvæ I ate would have made troublesome mosquitoes and other insects.

Iva: How could you breathe down in the water?

Dragon-fly: There was a long tube in my body the size of a pin, and at the tail were five points, or spikes. Through these I obtained air from the water, as a fish does.

Harold: Did you always go creeping along in the mud?

Dragon-fly: No, indeed; I could force water through the tube in my body just as you shoot it through a squirt-gun, and that pushed me through the water very swiftly. I believe the first man who thought of pushing a boat through the water with a propeller got the idea from some of my relatives.

Iva: Did you change from larva to pupa?

Dragon-fly: Certainly; all insects do that. My body and head were larger then than now. The case I lived in grew clear like glass, my eyes grew brighter, and I left the deep part of the pond and came near shore.

Glenn: How long did you stay in the water?

Dragon-fly: About a year; then I got tired of living in the mud. I did not care to eat, and I am sure my neighbors were not sorry for that. I began to long for sunshine and fresh air, 
so I climbed up on the stem of a tall plant till I was above water. Then I stuck the sharp hooks on my feet deep into the stem and clung. The sun and wind soon dried the case I had lived in. I began to squirm about and it split open in the back. My head, wings, and long body appeared, and there I hung as if dead.

Glenn: It was well that some hungry bird did not spy you just then. What did you do next?

Dragon-fly: I waited till my wings were dry and stood straight out as they do now. When I had grown quite strong, I sailed away in the air hunting for something to eat. I left my

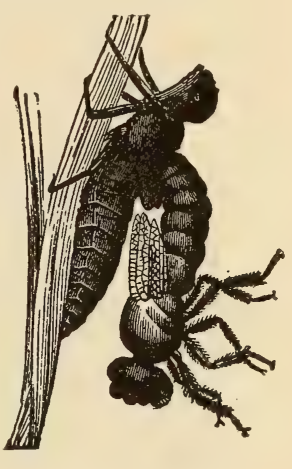
dried-up skin hanging to the plant. Perhaps when you visit the pond next time, you may find it and others like it hanging there.

Harold: Do you still wear your mask?

Dragon-fly: No; I have no use for it now, and it was left behind.

Hazel: Are all dragon-flies the same size?

Dragon-fly: No; some are quite small, while others have wings measuring four inches from tip to tip, and their bodies are three inches long.

Iva: Have you any relatives?

Dragon-fy: Plenty of them.

To-day I saw the dragon-fly

Come from the wells where he did lie.

An inner impulse rent the veil

Of his old husk; from head to tail

Came out clear plates of sapphire mail.

He dried his wings; like gauze they grew;

Through crofts and pastures wet with dew

A living flash of light he flew.

-Tennyson. 


\section{Day-Flies and Other Flies}

Hazel: Let us take a walk. Here we are at the river. How pretty the waterfall looks!

Glenn: There is something alive in that bundle of sticks!

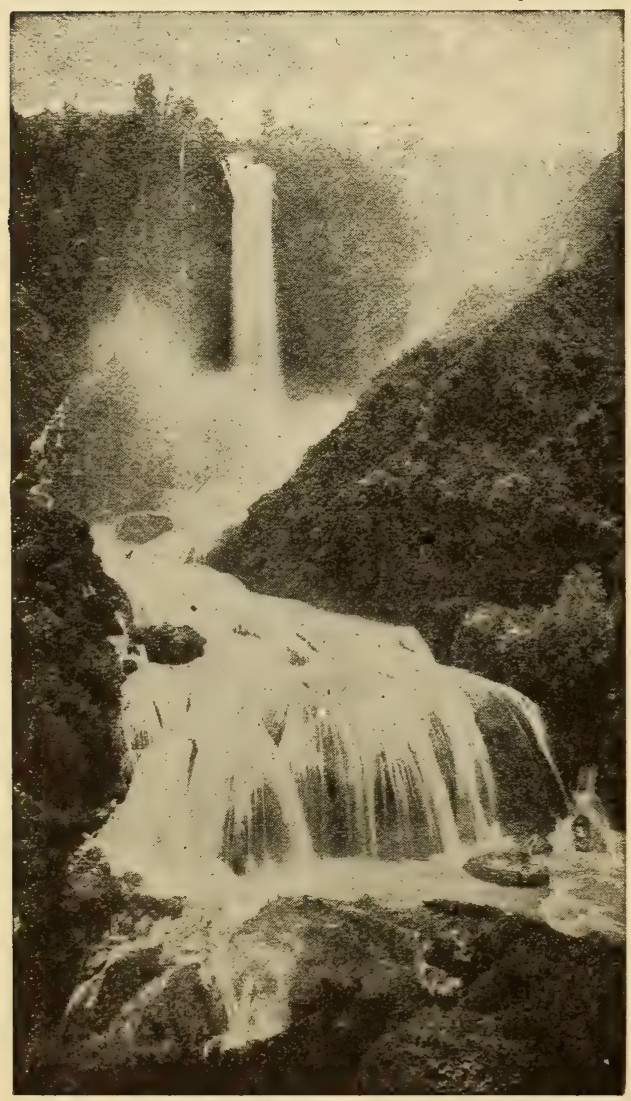

Mother: That bundle of sticks, as you call it, Glenn, is the home of the caddis-fly larva.

Glenn: Why does it stay in such a place?

Mother: The caddisworm, or larva, has a soft body, which would very soon be gobbled up by a larva of the dragon-fly or some hungry fish; so it gathers fine stems of plants, bits of stick, tiny pieces of bark or wood, and builds a house. Sometimes it uses coarse sand or small pebbles, and it will even crawl into an empty snail's shell, and take up its abode there.

Harold: It does not need a very big house, for it can not be an inch long.

Mother: If you were small enough to enter one of these homes, you would find it round inside like a tube, and lined with silken curtains, which the caddis makes, for it can spin like a cater-

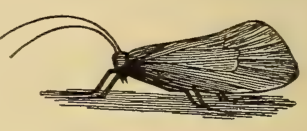

CADDIS-FLY 
pillar; so it is very cozy inside, even though the house is under the water. All caddis houses are not built alike, but all are round and smooth inside. As the little creature grows, it keeps moving toward the front end, and builds on a new part, which is larger; then it cuts off the back end of the house, which has become too small.

Glenn: How does it get anything to eat?

Mother: It crawls along the bottom of the stream, taking its home with it. Sometimes the house looks as if it were moving itself. The head of the caddis and the first three rings of its body have a horny covering, which protects it, and it reaches outside the door and gets its food.

Harold: What does it eat?

Mother: Almost anything that comes its way,- leaves or

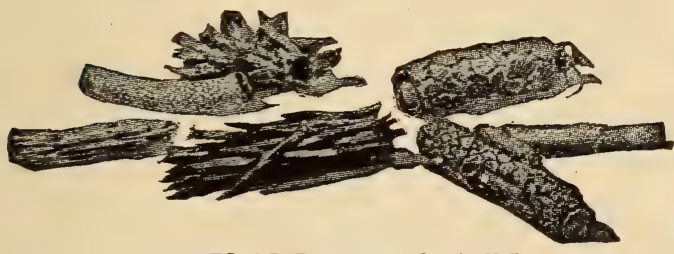

HOMES OF CADDIS-FLY LARVAE insects. The caddis does a curious thing when making its dwelling. If it comes to a small snail, it glues it to the house and walks away, whether the snail is willing to go or not. Some of the caddis larvæ build houses that are fastened in one place, and then they spin a little net at the front, which catches the insects they use as food. Here is a picture of the net. The little fisherman selects its building place where it can fasten its net to a frame of leaves or stones beside a swiftly flowing stream. The mouth of the net opens up

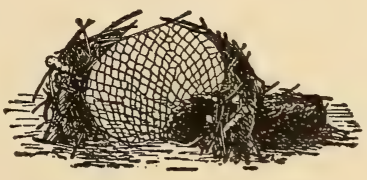
stream, and the water flows through it, as it is made of material which hardens in water, and is woven in the shape of a bag. Near the open end is a small passage leading to the home of the fisherman, which is fastened to a stone. When it is ready for dinner, all it has to do is to go to the net and eat. 

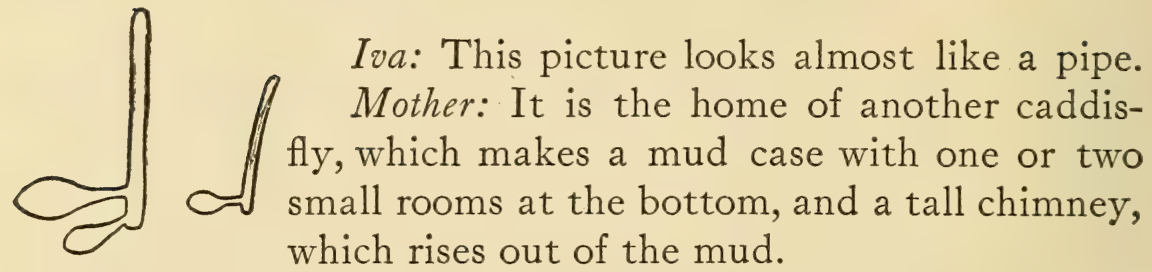

Glenn: What does the caddis-worm do when it turns to pupa?

Mother: Like other insects, it goes to sleep; but it first shuts both the front and back doors, for it has a good many close neighbors. The doors are simply gratings of silk, which let the water pass through freely. After it has slept for two or three weeks, it wakes up and comes out of its house in a hurry, swims to some dry place and shakes off its pupa-case. As soon as it gets its wings, it has a great liking for the light, and large numbers of caddis-flies can be found near street lamps. There are many kinds of them. Some are very small, and may be seen flitting about ponds and lakes. Others fly only at night-time and remain quiet during the day.

Hazel: Do they lay their eggs in the water?

Mother: Yes; the mother fly carries her eggs about in two bundles fastened to her body, probably to keep them warm before they are placed in the water. Even though she has wings, she can swim, and when ready to leave her eggs, she crawls down the stem of a plant several inches into the water, fastens them to the plant, and leaves them there to hatch.
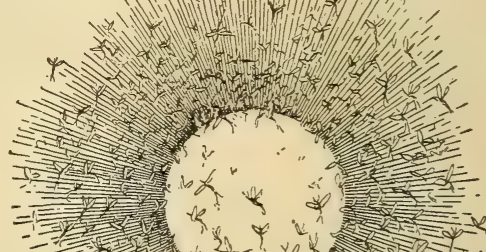
Harold: Does the dragon-fly have other relatives than the caddises?

Mother: Yes, many more. Here come several of them new.

Iva: Why, those are May-flies.

Glenn: I have sometimes heard them called day-flies. I wonder why they have that name.

Mother: Because they live only one day, often only a few hours. They have still another name, eph-em'e-ra, which means the child of an hour. Here is a picture of one which you may examine closely. You see it has a long, slender body.

Iva: And also two long tails like silky hairs.

Mother: When moving its wings, it rises in the air; but even though the wings are spread, if they are still, it falls, so it is continually rising and falling.

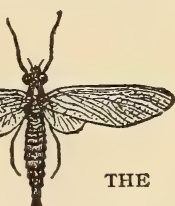
There are large numbers of them where there is much water.

Harold: Do they live just one day?

Mother: Only one day as May-flies, but they live as larvæ two or three years. When ready for wings they come to the

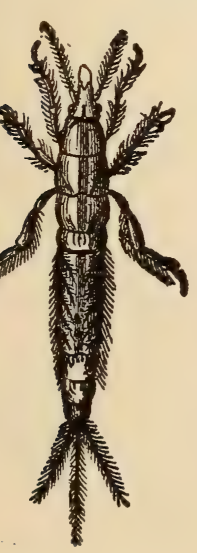

LARVA OF MAYFLY top of the water and leave their pupa-cases so quickly that they seem to fly out of the water. On bright, sunshiny days swarms of May-flies may be seen dancing in the air. There is only one thing for which they stop their flight, and that is to lay their eggs. These are placed in the water in little bunches, and there may be several hundred in one cluster. They soon sink to the bottom, where they hatch, and then each little youngster hunts for a mud bank, where it lives in the same way that its mother did for two or three years.

Iva: What do the May-flies eat, mother? 
Mother: They have no time for eating, and they have no mouths to eat with. After dancing about in the air a few hours, they go to sleep never to wake. Their dead bodies are sometimes found in such quantities in some parts of Europe that they cover the ground like snow, and are gathered in heaps to fertilize the fields.

\section{The Ant-Lion}

Hazel: Here is the picture of an insect that looks like the dragon-fly.

Mother: That is an ant-lion.

Glenn: Why, it does not look like either an ant or a lion!

Mother: This is the picture of the perfect insect, and it now looks like a dragonfly; but it looked quite different as larva and pupa. You would hardly think such an elegant insect, with four pretty lace-like wings, once looked like this picture of the larva.

Iva: It is shaped like my flat-iron; see $M$ its hairy legs.

Mother: Here is a picture of the little cradle it lies in. The larva comes from an egg which the ant-lion lays in the sand. Here is its picture after it turns to pupa.

Hazel: It looks like a little doll with eyes on the sides of its head.

Mother: The ant-lion lives on land, and is found only in warm countries. Its larvæ like dry, hot sand. They eat ants and other insects. It has an odd way of catching its prey, and uses more wisdom than one would think it capable of. It is short and clumsy,

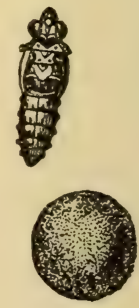

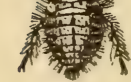

LARVA OF ANT-LION moves very slowly, and can only walk

COCOON AND PUPA OF ANTLION 
backward, but it sets a trap in the sand for ants, and they tumble into it. It chooses a spot where the sun shines, and where a colony of ants have set up housekeeping. It has no tools to work with except its strong jaws and head. It first plows a furrow by pushing its body backward through the sand in the form of a circle two or three inches in diameter. Then it makes a deeper furrow by loading sand on its head with its fore leg, throws its head up with a jerk, and the sand is thrown outside the circle. It works till it gets around to where it began, then goes back the other way, and keeps hard at work till it has a hole about two inches deep.

Harold: What if a stone is in its way?

Mother: It puts its head under the stone and pushes it to the top and outside the circle. This means hard work, especially if the stone is two or three times as large as itself. Sometimes after tugging a long time, just as it gets the stone to the top, it rolls down again. Then it tries again. But after trying eight or ten times, it sometimes gives up, and begins to dig another hole. When the trap is finished, it hides in the bottom, covers its body with loose sand, all excepting the big jaws, which it opens wide, and there waits for its prey.
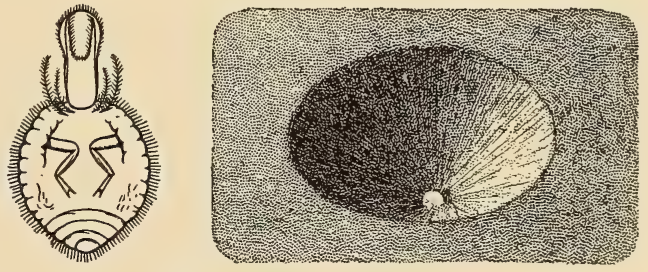

THE YOUNG ANT-LION AND ITS PIT OR TRAP

Here is a picture of a trap; it is shaped like a funnel.

Harold: A clever trapper, I must say; but I should think it would have to wait a long time for its dinner.

Mother: Not so long as you think. Soon two or three ants come along, and one goes near enough to look over the brink, sees the wide-open jaws at the bottom, and starts to run away; but the slippery sand gives way under its feet, and down it rolls into the waiting mandibles. 
Glenn: Does the ant-lion eat it when it falls into the trap? Mother: No, it only sucks the juice out of its body, tosses it out of the funnel with an odd jerk of its head, and then settles back to wait for another victim, as a cat-watches for a mouse. Now you know why this insect is called the ant-lion.

Glenn: Nearly all insects seem to hunt for others to eat. Mother: Perhaps they are like people who kill ducks, turkeys, chickens, cattle, sheep, and the pretty fish.

Hazel: I wish people would not kill and eat things that have life.

Mother: I wish so, too. In the new earth "the cow and the bear shall feed; their young ones shall lie down together: and the lion shall eat straw like the ox. . . . They shall not hurt nor destroy in all My holy mountain." There the people will eat luscious fruit instead of the flesh of animals, and I believe even the insects will not prey on one another as they do now, for the Lord says, "Behold, I make all things new."

Hazel: As you told us of the ant-lion, mother, I thought of the psalm we read this morning, about the wicked man who "sitteth in the lurking-places of the villages: in the secret places doth he murder the innocent."

Mother: As the ant-lion waits in secret for its prey, so those who sell strong drink lie in wait for those whom they ruin, both body and soul. When their victims have no more money, they throw them out as the ant-lion does the ant it has robbed of life.

Glenn: Some of the boys asked me to go into the saloon and hear the music and see what the men were doing inside.

Hazel: If you had gone, you would have been like the ant who looked down into the trap of the ant-lion.

Mother: The only safety is in keeping far away from all such places; for they are traps set for the innocent, and many, many boys and girls are ruined because they can not see the 
harm in going to see what is being done behind the screen. I hope my boys will never forget the coursel of the wisest of men: "Enter not into the path of the wicked, and go not in the way of evil men. Avoid it, pass not by it, turn from it, and pass away."

Harold: Did you say the ant-lion is found in the Southern States?

Mother: Yes; and your auntie told me she saw ant-lions in Australia, and was interested in watching their habits.

Iva: I wonder if bigger insects than ants ever fall into their trap.

Mother: Sometimes beetles and spiders tumble in, and the ant-lion tries to make them its prey. Then there is a fierce battle. The larger insects sometimes escape, but may lose their balance, or get tired out in their efforts to get away, and then they are caught by the sickle-shaped jaws. This shows that even the strongest should not go in the way of temptation and danger.

\section{The White Ants}

Iva: Are there any white ants here, mother?

Mother: No; they inhabit tropical countries, such as India,

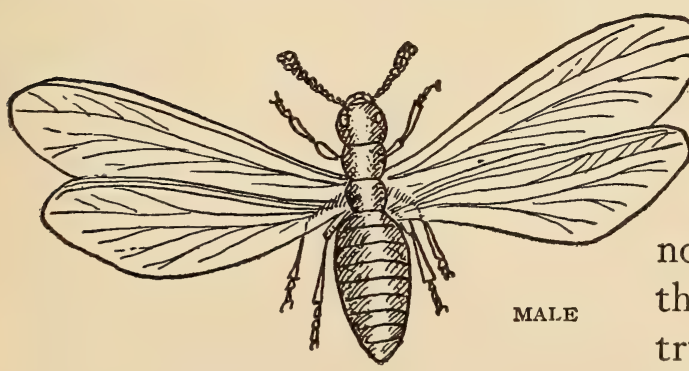

Africa, Australia, and some parts of North and South America, and Europe. But what we call white ants are not ants at all, although they look like them. Their true name is termites, and those who study insects say they belong to the Neu-rop'te-ra family. Do you remember in which family the ants are found? 
Harold: In the Hy-men-op'te-ra, with the bees, wasps, and hornets.

Hazel: Do the termites have wings like the ants?

Mother: The males and females do, but the workers and soldiers have four wings the same size, while the wings of the

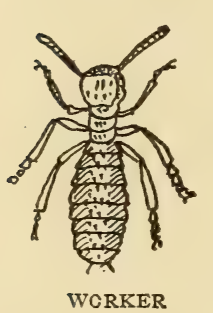

WCRKER ants with whom you have been talking, have one pair of wings larger than the other. This and the preceding page show pictures of two members of the termite family. They are larger than the live insects. One is a picture of the male termite before he loses his wings. The other is the picture of a worker, which is as big as a large ant. They have round heads, short jaws, or mandibles, and they are all blind.

Hazel: How can they work when they are blind?

Mother: The termites are miners and masons, and choose to live in the dark. They are like the little fishes found in the Mammoth Cave; for they have places where eyes should be, but they do not grow.

Harold: Do they lose their wings like the ants?

Mother: Yes; after they take their wedding trip; and great numbers of them die. One afternoon toward evening, in Australia, Aunt Jennie saw the air filled with white insects, which made it appear as though there was a snow-storm. They flew and then fell to the ground. When she examined them, she found they were termites.

Iva: What do they do after their flying journey?

Mother: Those that remain lose their wings after finding their mates, and become kings and queens of new homes. These have eyes and can see. The worker termites care for them, and provide shelter and food for the family. They have grayish-white bodies, and jaws strong enough to bite almost anything. 
Glenn: Did you say some of the termites act as soldiers? Mother: Yes; and very brave ones they are, too. Here is a picture of one. They have heads nearly as large as their bodies. Strange to say, the soldiers are as blind as the workers, though it is their business to defend the termite home from all kinds of enemies.

Hazel: Would they fight a man?

Mother: They surely would, as many have found to their sorrow. If a blow is struck on their nest, they run out quickly. It does not take them long to find the enemy, and they bite and pinch his flesh

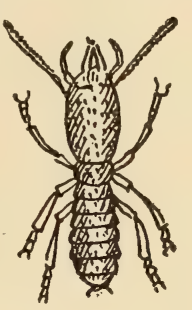

SOLDIER TERMITE till they bring the blood. With their sharp pinchers they hang to the wound, and will permit themselves to be torn in pieces before they will let go.

Hazel: What savage creatures they must be!

Mother: They are. While they are fighting, they strike the ground and make a slight sound, which is heard by the workers below, who answer with a little whistle which means, "Here we come;" and they soon appear, each carrying a load of mortar to mend any damage done to their home. When the battle is over, most of the soldiers go back into the nest, but a few remain outside to see that the work is well done. They keep striking the ground as they did during the battle, which makes the working termites work faster, till all needed repairs are finished. A gentleman saw Negroes attack the ant-hills in Guiana. They did not dare to go near them without first digging a little ditch and filling it with water. They would then shoot at the nest. When the ants rushed out, they were drowned in the ditch.

Hazel: Why did they attack the nests?

Mother: The termites store corn in their homes, which the natives take away; and they also eat the ants themselves, and think them a choice food. They roast them like coffee, and 
can never get enough. They also mix them with flour and make a kind of cake. Travelers who have eaten it say it tastes like sugar and cream.

Hazel: Do the termites make homes like the ants, mother?

Mother: Yes, very large ones. You would scarcely think this feeble-looking insect could build a dwelling so large. Mr. Smeathman, who spent a long time in Africa, saw them ten or twelve feet high; another traveler saw them twenty or thirty feet high. Aunt Jennie saw some in Australia that were higher than a man. They appear like hillocks or great rocks.

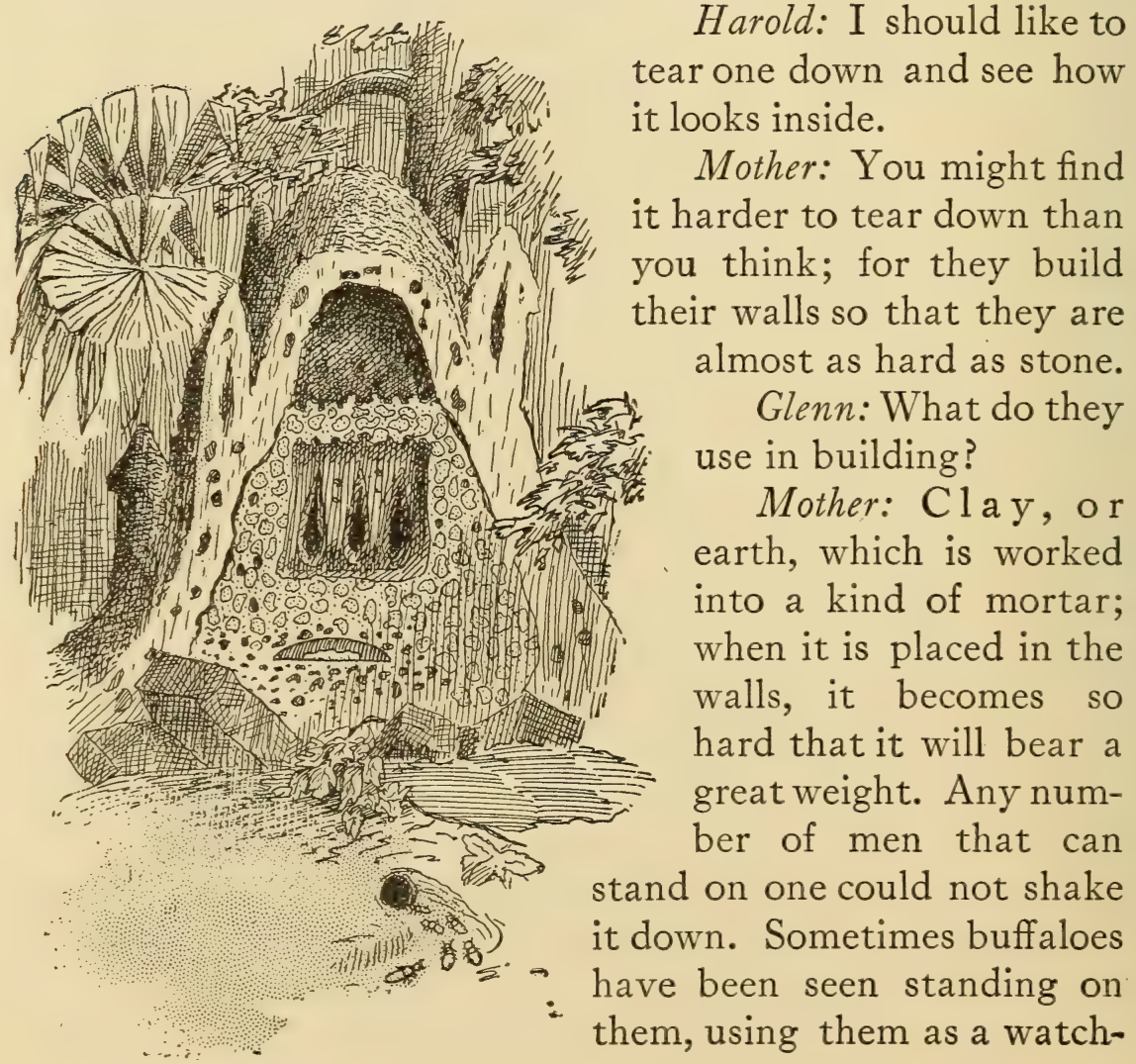


tower from which to see if a lion or panther was near. Hazel: Such nests must be solid clear through.

Mother: No, they are hollow, the wall being about fifteen or twenty inches thick. The picture on the preceding page, showing the inside of the nest, will help you to understand it better. In the top is a large empty room, which takes about one third of the space inside. It is left vacant, probably to keep the dwelling cool. In the inside of the dome, and even under it, are many rooms and galleries, both large and small. In the sides of the dome near the wall are large storerooms, in which are stored gums and juices of plants dried and made into powder, which the termites use as food. On the first floor is the queen's apartment.

Hazel: Do the termites always make their nests in the ground?

Mother: No; there are some kinds which make them in trees. This picture was drawn from a specimen in the Smithsonian Institution at Washington, D. C. Some of these nests are of great size. The termites that build in trees make covered roadways, or tunnels, through which they travel to the ground. Some nests are made of bits of wood stuck together with a kind of gum. All these nests are so firmly fastened to the trees in which they are built that they can not be shaken down even by severe storms. The termites sometimes choose to build their homes in the roof of a house, where they do

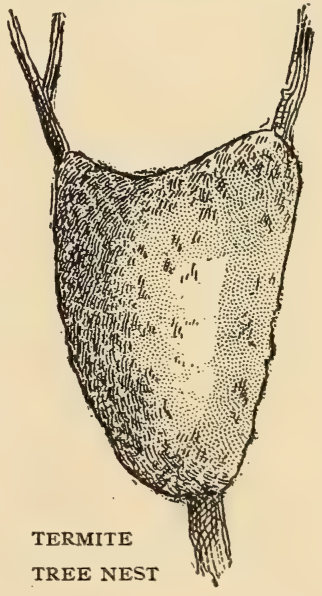
great harm, and in Africa, near the equator, they make nests like big brown toadstools, only they have four tops like umbrellas, instead of one.

Iva: How does their queen look? 
Mother: Here is her picture, so you may see for yourself. Harold: She doesn't look at all like the other termites.

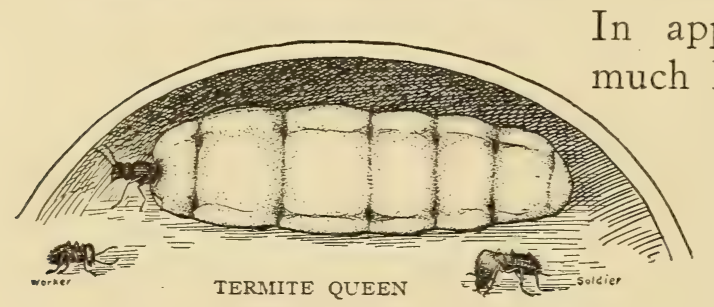

In appearance she is very much like a potato.

Mother: Aunt Jennie saw one of the queens in a museum in England, and thought her the ugliest-looking insect she ever saw. She sometimes weighs as much as thirty thousand workers, and is six inches long, but most queens are about the size of my thumb. The younger queens are much smaller. The larger the queen, the more she is admired by the family who live in the house with her.

Iva: Does she lay as many eggs as the queen bee, mother?

Mother: A great many more; in fact, that is her business. She lays sixty eggs a minute.

Iva: That is one every second, and three thousand six hundred an hour, making over eighty thousand a day.

Mother: Mr. Smeathman thinks she lays eggs during the whole year, so you can figure out how many millions that would be. The eggs look like tiny black beads.

Iva: Is the king as large as the queen?

Mother: He is only about an inch long.

Hazel: Can the queen walk?

Mother: She is kept captive in her cell, which is shaped like the one in the picture. The doors are so small to this apartment that she can not get through them, and so does not move at all. The workers take great care lest any harm come to her, and supply her with all the food she needs.

Glenn: Do the workers care for the eggs as ants and bees do?

Mother: Yes; they carry them to rooms prepared to re- 
zeive them, which are above the royal cell. These rooms are small, and divided by partitions of sawdust glued together with gum.

Harold: I should think termites would produce eggs enough to cover the world, and cause all other insects to perish.

Mother: They have many enemies. Birds are greedy to swallow them; ants eat thousands of them; even the natives kill them for food; and in tropical countries ant-eaters devour quantities of termites. Here is a picture of an ant-eater.

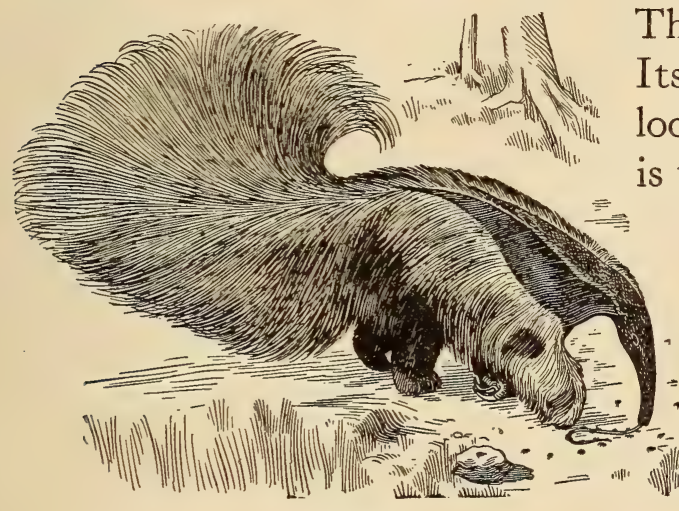

ANT-BEAR

This is called the ant-bear.

Its long, pointed nose, which looks like the beak of a bird, is very useful to it. None of the ant-eaters have teeth, but they have long, sticky tongues, which they run into the hole where the ants are, and the ants stick to their tongues. As soon as the tongue is covered with ants, it is quickly taken into the mouth, and is soon ready for another supply. Its head is about a foot long and very narrow. The ant-bear cleans its little mouth and face by rubbing them on its knee-joint, which bends for that purpose.

Iva: Why does it have such a long, bushy tail?

Mother: It shields it from the sun and rain. The ant-bear is fond of lying down, and when doing so uses its tail as a blanket, for it reaches over the whole body. It has a keen sense of smell, and can follow a person as a dog does a rabbit. It destroys millions of termites, as do also the ipi, or pangolin, in Africa, and the armadillo in Central America. When pursued, the armadillo will roll itself up into a ball and 


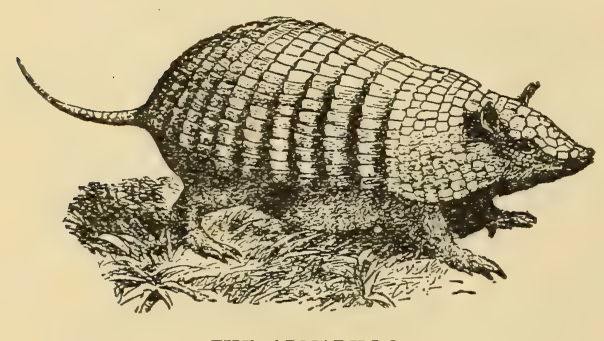

THE ARMADILLO

"play possum." It is sometimes tamed and kept by people in cities and also in the country, to free their homes from ants.

Harold: Please tell us how the termites do harm, mother.

Mother: They bore tunnels in timber, and if people are using the wood in which they choose to work, you can see they do much mischief. Some think they eat the wood for food, and if that is true, they have good appetites, for they never seem satisfied. They do their work in a strange way, eating only the inside of wood or trees. Chairs, tables, and other furniture may seem to be all right; but if one sits down in a chair in which the termites have been working, he may soon find himself on the floor; or the table may break down under the weight of the dinner placed upon it.

Glenn: Why don't they eat the outside, too?

Mother: The termites are blind, and they choose to work in the dark. If compelled to come into the light, they build covered roadways through which to pass. These tunnels are seen on trees and on the foundations of houses in Australia. Wherever the termites live, these tunnels are found stuck on walls, or hanging from roofs like icicles.

Harold: It must take them a long time to bore through solid wood.

Mother: They have been known to tunnel a table leg from bottom to top, and then go through the top of the table, down through the leg on the other side, in one night, and during the same time they ate what was in a trunk placed on the table. Auntie went to a church in

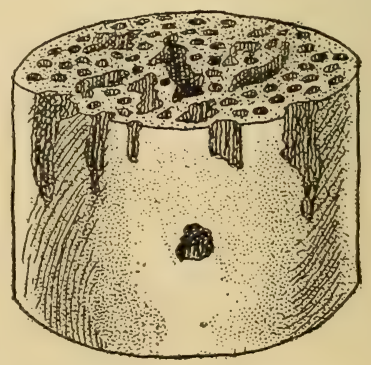

WOOD EATEN BY TERMITES 
Sydney, Australia, where the floors and partitions had been eaten away, leaving only the outside shell of the boards. A man near where she lived found that the termites had eaten through the wooden mantel around his fireplace, leaving only the outside. After eating the timbers of a house, they sometimes fill the tunnels they have made with mortar to keep the house from tumbling down. But they do this only when they intend staying in the place a long time.

Harold: Do they eat anything except wood, mother?

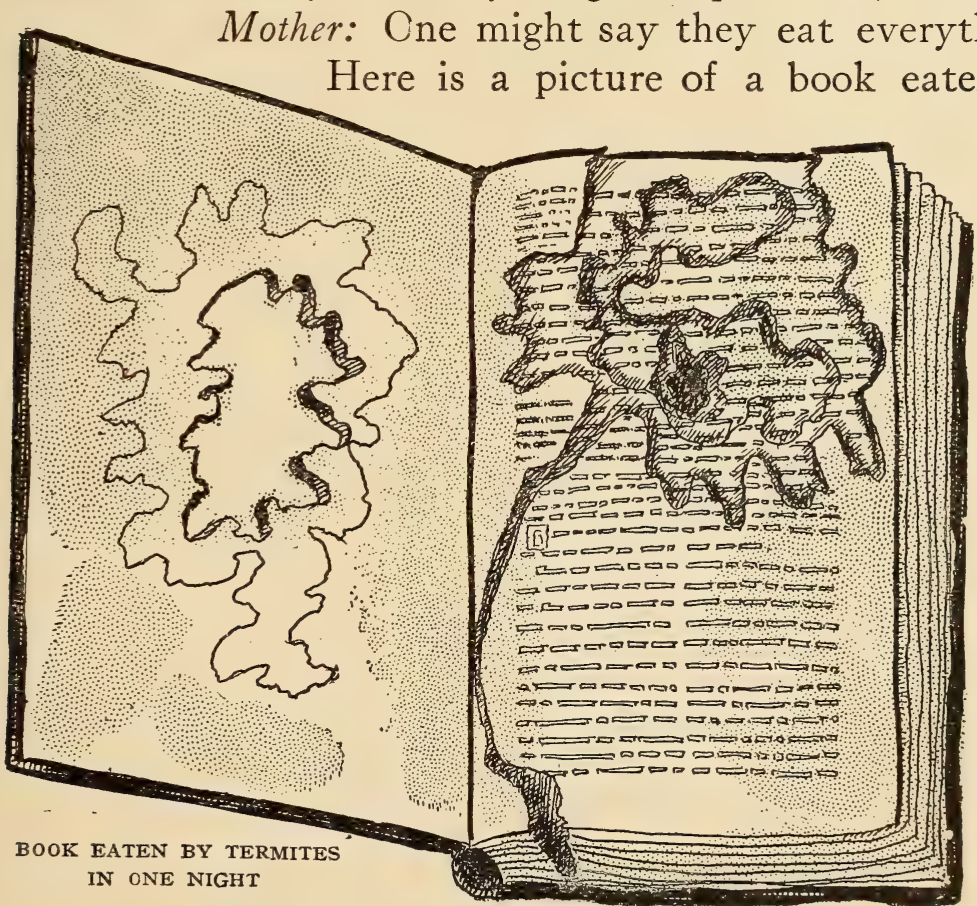

termites, showing how it looked when the covers were opened. There are big holes two inches deep through the leaves. I saw this book in the Smithsonian Institution in Washington, D. C. The picture of the piece of wood found in the same place, shows how close together they bore their 
tunnels. In the South Kensington Museum in London, there is a box lid only one eighth of an inch thick, which has been hollowed out, leaving an outside shell as thin as paper. Your Uncle Harry, who is a missionary in Africa, asked me to send him some maps; but he says they must be made so they can be taken down and folded away every day, so the termites will not get a chance to eat them.

Hazel: How difficult it must be to live in countries where there are so many harmful insects!

Glenn: I would keep two or three ant-bears near the house.

Mother: In an arsenal in France the termites bored through the woodwork, pierced the cardboard covers, and ate the public records kept there. They left only the covers, and the edges of the leaves. In the South Kensington Museum there is a piece of sheet lead one eighth of an inch thick filled with holes

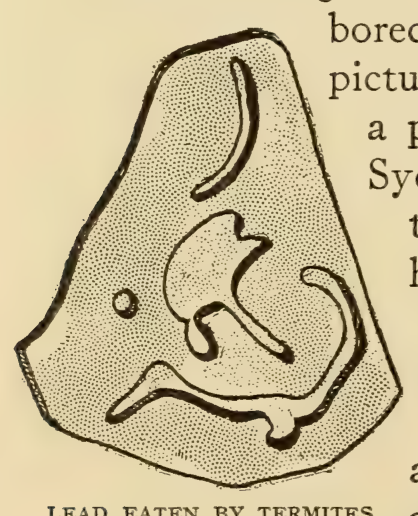

bored by the termites. This is a picture of it. There one can also see

a piece of sandstone brought from

Sydney, Australia, filled with tunnels these little creatures have made.

Glenn: They must have teeth of iron.

Mother: Here is a picture of a piece of timber taken from an office on the island of St. Helena. The knobs standing out are knots in the wood; they were not touched. The wood was eaten away its entire length, so it would be about as strong as a sheet of brown paper to support a building. Iva: I should think the houses would fall down where the termites work that way.

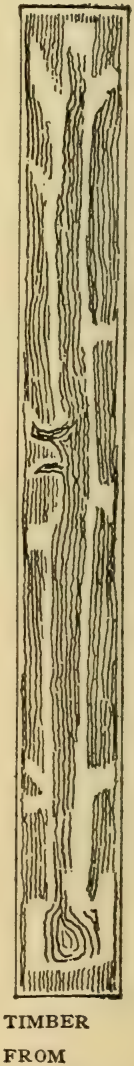

ST. HELENA 
Mother: They do. In France, at a public dinner, the floor of the dining-room gave way, and the host and all his guests tumbled in a heap into the cellar. In the Museum of Natural History in Paris, the timbers that supported the floor of that room may be seen. The termites are a great pest, yet we may be like them in industry and perseverance.

\section{The Spider}

Harold: To what family of insects do you belong, Mrs. Spider?

Spider: I am not an insect at all. Look at my picture, and see if there is any difference between it and this picture of a bee.

Harold: You have eight legs, while the bee and all true insects have only six; and you have no wings, while insects have two or more; and there are only two parts to your

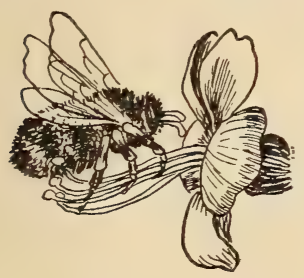
body, while most insects have three. Your head and the fore part of your body seem to be one.

Glenn: Do you lay

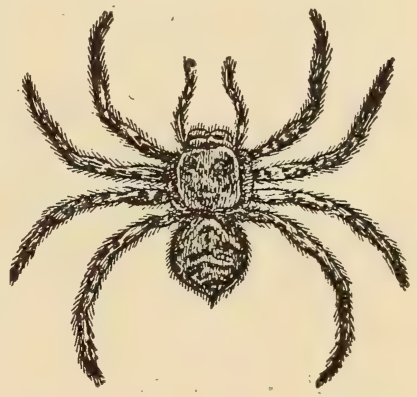

eggs? and do they hatch as larvæ and change to pupæ?

Spider: We lay eggs, but when they hatch, little spiders come out of them. These we carry and care for until they are able to provide for themselves.

Iva: Do you have a sting like the bee and the wasp?

Spider: I bite instead of sting; but my bite will not hurt anything except a fly or some other insect.

Glenn: Do you have hundreds of eyes, as some insects do?

Spider: I have only eight, but they are so placed in the different parts of my head that I can see in all directions at once. 
A few spiders have six eyes, and a still smaller number have only two.

Hazel: Are you different from insects in other ways?

Spider: My body is soft, and has no hard, horny covering, such as most insects have. I shed my skin as I grow older and larger, while most insects do not. I am able to run if I lose half of my legs. If I lose a leg, a new one grows out in its place.

Harold: Are there many kinds of spiders?

Spider: Hundreds. They are classified into five principal families, according to their habits, and there may be many different kinds in one family. All belong in one general class called A-rach'ni-da.

Hazel: What are your family names?

Spider: First, hunting-spiders, which run about hunting their prey; second, wandering spiders, so called because they have no homes; third, prowling spiders, which run about near their webs to hunt for food; fourth, sedentary spiders, sedentary meaning to sit much of the time, or to settle in one place; fifth, water-spiders, which are also sedentary, but live in water instead of on land. We can all dive in the water, and some of my cousins can build rafts. We hunt, and plant mosses and ferns, and are famous spinners and weavers. We make bridges, balloons, and parachutes. One of my cousins makes a house lined with the finest silk curtains, and has a door fastened in place with a hinge. Another makes a tent to live in; one builds a tower, while another spins silk which is woven into beautiful dresses and ribbons. We have opened prison doors, too, and we are weather prophets.

Harold: I think Solomon watched spiders in his palace; for he said, "The spider taketh hold with her hands, and is in kings' palaces."

Hazel: How do you make your web? 
Spidcr: We have no spinning-wheels such as your grandmother used, and yet all spiders can spin. On the under side of my body there are six tubes called spinnerets, and in each tube there are many smaller ones. Some people say there are a thousand.

Iva: Do you spin wool, cotton, or flax?

Spider: None of them. There is a kind of gum or glue in my body which comes through the tiny tubes in the spinnerets, and it makes the finest threads you ever saw. They look like the threads that come from a spoon dipped in boiling sirup. As they come from my body, they become hard and strong, and I weave them into webs and nets. I can spin six strands at one time; and if I wish to

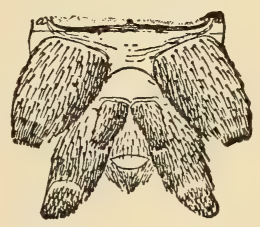

SPINNERETS make a strong cable I simply twist the strands, together. Harold: If there are so many tubes in the spinnerets, I should think there would be hundreds of threads instead of one.

Spider: I bend my spinnerets together so the threads twist into one, just as there are many strands in a rope. Think how fine each strand must be when hundreds of them twisted together make a line no coarser than a hair.

Hazel: The silk must be strong, since it holds you up.

Spider: I am not afraid of falling. Watch while I spin a long thread.

Harold: You go so fast. Go slowly please, and show us how you make those webs that look like a wheel.

Spider: First I press my spinneret on the place where I wish to begin, and that fastens the end of the line. Then I drop down, spinning a thread as I go, to reach some other place that will make a good foundation. I can begin or stop spinning whenever I choose.

Hazel: How do you fasten your line at the other end?

Spider: I take the thread in my hand and walk around to 
the point I wish to reach, spinning as I go. A good strong pull straightens the line; I make it fast, and then walk back over my suspension-bridge to the place where I began. I fasten another line, and go back and forth, spinning a thread each time to strengthen the cable. Sometimes a branch serves as a foundation for the web, or I fasten it between two bushes.

Iva: I should like to know how you make it look like a wheel.

Spider: I spin the rays - the strands that look like the spokes of a wheel - first. I give every ray a strong pull to make it straight, and then spin the threads round and round from ray to ray, beginning at the outside, until it is a perfect, beautiful wheel. The inside lines are closer together than those on the outside. When all is done, I can sit in the center. I have a cozy little parlor close by lined with silk curtains, where I sit with a line in my hand which runs from the web. This is my telephone. When a caller comes and shakes the web, I feel it moving and quickly go to see who is there. Even though Mrs. Fly should say with her very loudest buzz that she did not mean to intrude, that she came to my door by mistake, and that she will go away without making me any trouble

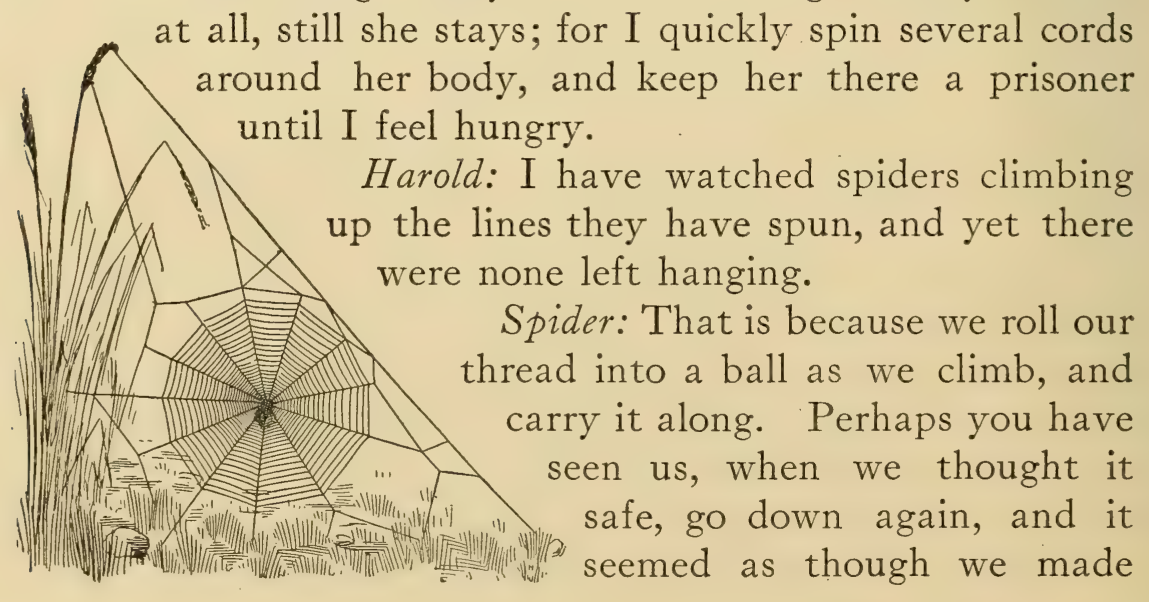


big jumps, and still the line held us up. We go more slowly and steadily when we are spinning.

Hazel: How is it, Mrs. Spider, that you can run over your web as easily as can be, but if a fly touches it, she gets all tangled up and can not get out?

Spider: One reason is we use two kinds of silk in making our webs. That which makes the spokes of the wheel is smooth, while the lines that cross them are covered with tiny drops of a sticky glue that will not get dry. It is said that there are about two hundred drops to every inch of line, and that in a whole web there are ninety thousand drops. They can not be seen unless one looks through a strong glass.

Harold: Why don't your feet stick like those of the fly?

Spider: Because they are made differently. Our feet have claws like those on a lion's foot. One claw is bent like a hook,

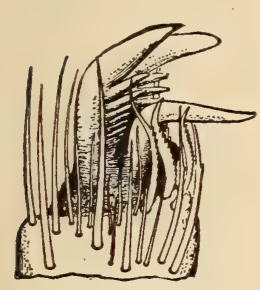

SPIDER'S FOOT so we can cling to the web and walk as easily as you can on a floor. The other two claws have combs, which we use to comb our hair and to clean our webs. A fly's foot has gummy cushions, and these stick to the web as soon as they touch it.

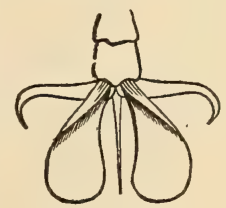

FLY'S FOOT

Glenn: I have seen webs in the grass which looked like lace when the dew was on them.

Spider: They are closely woven, and down at one side you will find the little spider who makes such a web waiting for her breakfast. She has a little chimney at one side, only it goes down instead of up. If she hears a fly buzzing that has been caught in her lacy web, she is all ready to tie its legs and wings and carry it away in a neat bundle; but if a blundering beetle comes tumbling down, she runs out at the other end of her chimney into the grass, where she is safe.

Harold: Which kind of spider makes the largest web? 


\section{The Spider's Oration}

Come, children, who fancy we spiders are fools, And view the lace houses we build without tools. I'm just about finishing one at the lattice; Come quick, and I'll operate for you all gratis. And where do you think are my shuttle and loom? You see no machinery here in the room,

No silk thread nor cotton, and yet you all see This wonderful fabric is woven by me.

It's all in my little round abdomen here; No steam apparatus to burst, never fear. It's hard to explain to you just how I do it; Look sharp, and perhaps your bright eyes will see through it.

What would a fine lady not give to possess A spider-web drapery o'er a silk dress?

The weaver, if human, would win a great name, While artisan spiders no merit may claim For the unobtrusive and wise.

We try to relieve you of troublesome fies; We're hunted and scouted with duster and broom, And all our fine tapestry swept from the room.

When questions, "What were spiders made for?" arise, Some wiseacre answers, "They're made to catch flies." "And what were flies made for?" He answers again, "To feed hungry spiders; I' $m$ sure this is plain." Now this is chop logic, or reason in rings. Observe how I amputate this beetle's wings. There! done like an M. D., with minus a tool. Now, have I not proved you a spider's no fool?

I've shown him a weaver, the best in the nation, An architect planning his own habitation, A maker of nets to catch fishes with wings, A surgeon accomplishing wonderful things, $A$ skilled decorator of mansion and cot, A plain, honest worker, content with his lot; And last, you'll admit, little children, I know it, I've proved him an orator, scholar, and poet. - Mrs. Mary N. VanDyck. 
Spider: My cousin Neph'i-la is the largest web-spinning spider. She lives only in very warm countries. Her webs are several feet across, and are made of silk so strong that even birds are snared in them. Nephila chooses grasshoppers and other large insects as her food. Her body is very large. Her mate is so small that it is like a man six feet high having a wife seventy-five feet tall. But he is so spry that he quickly gets out of the way if his big mate is inclined to be quarrelsome, and he knows his life depends on his doing so. When travelers go through the forests, they are obliged to use knives to cut away the big webs which stretch across their path. Nephila has a smooth body, and her legs are sometimes six inches long.

Glenn: How many spiders live in one web?

Spider: Only two old ones. Here is the picture of one of my cousins and her mate. $\mathrm{He}$ is much smaller than she, and he lets her make the house, get the meals, care for the spider babies, and do all the other work there is to do.
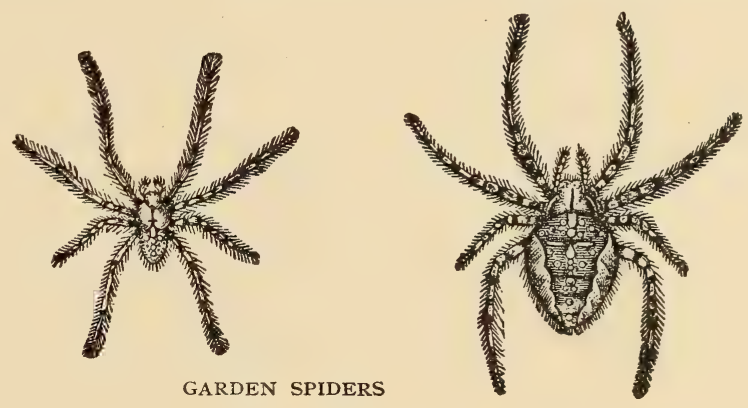

Hazel: Are spiders neat and tidy in their housekeeping?

Spider: I want no dirt nor soot in my house, and if anything falls on it, I shake the web until it falls out. If I can not get it out, I cut a piece away, and mend it with new lines.

Glenn: The smallest webs I ever saw are those in the corners of fence palings and of the house.

Spider: If you look closely, you will sometimes see the little spiders who live in them jump to catch a gnat or some such insect. As they jump, they spin a little line by which they climb back home, bringing their dinner with them. Spi- 


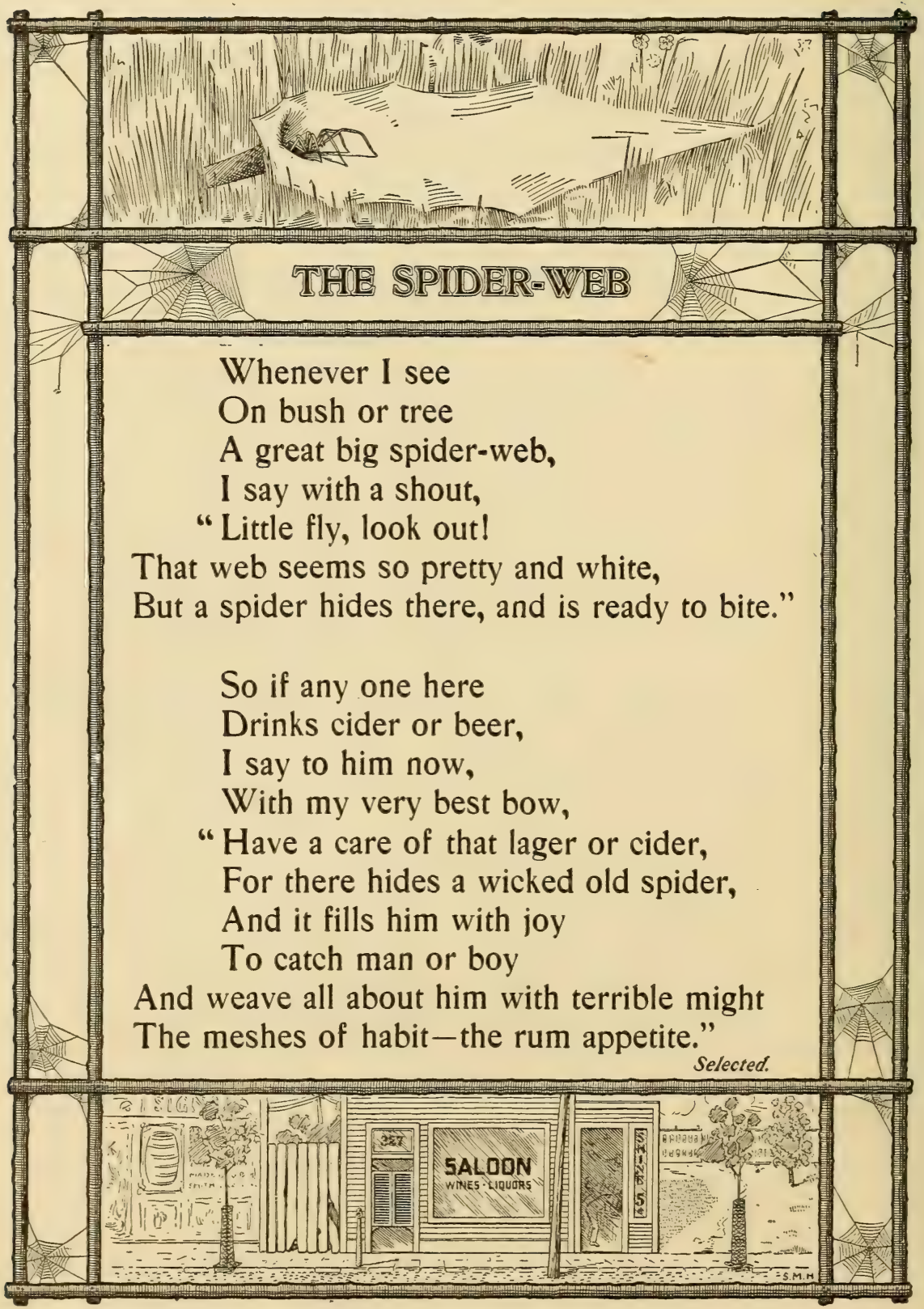


der hammocks are made by Cousin Li-nyph'i-a. She hangs them between two tall grass stems. One of her relatives makes two hammock webs, one under the other, and then stands under them to catch the insects that fall through.

Hazel: Do baby spiders make webs, too?

Spider: Some do. In Jamaica Cousin Ep-ei'ra's children have been seen making webs the size of a penny when they were seven weeks old. Their mother uses eighty yards of silken cord in making hers; it has been measured.

Harold: Sometimes when I look toward the sky I see so many silken lines it seems as if the air is full of them.

Spider: The finest webs float away in the air. There is a little black spider that goes up high to make her web, then gets on it, cuts the cords, and comes down to earth in her parachute. There is a spider in Texas that weaves a balloon two feet wide and six feet long, and hangs it by a single thread to a tree. When all is ready for flight, she and her children get into the balloon. With

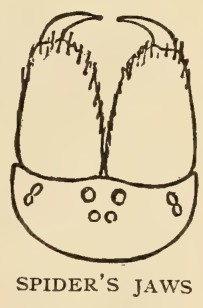
her sharp jaws she cuts the cable that fastens it to the tree, and sails away over the prairie in her air-ship.

Harold: Perhaps men will learn from spiders how to make air-ships as well as divingbells.

\section{MISS SPIDER'S WEDDING BREAKFAST}

A fat little spider married would be, So he made him a rope and climbed a tree To where Miss Spider was making a pie Of a bumblebee and a small house-fly.

And she wed him there in the morning light, When the dew on the grass was round and bright, Then spread out her table so lacy and fine, And off from her husband began to dine. 
She ate him all, from his head to his heel, And never a pang of remorse did feel, But, as curled up close in her cozy bed, "That spider was tough," to herself she said.

- Selected.

Spider: What would you think of trying to untwist one of my threads? In Australia our silken lines are used in the Melbourne Observatory. But the lines are too coarse as they are, so they take the silk spun by a spider that has few spinnerets, and divide it to place across the big telescope in squares so the astronomers can get lines just the right size. A Mr. Froude says he saw spiders which were kept so their webs might be at hand to be used when wanted.

Harold: Dr. Wilder, of Boston, Massachusetts, found a spider in South Carolina from which he wound a line of silk two miles long. Some persons think spiders could be reared and their silk woven like that of the silkworm.

Spider: I have a cousin in Madagascar who spins beautiful silk. She is very large, and is a cannibal. Her name is Halibe. She is very different from me. I am told that her mate leads a sorry life. Even when he tries his best to please her, she is apt to pounce on him and eat him
for her breakfast. As she has such a bad
temper, it is uncertain whether she can be
made to spin enough silk to pay or not. She
lives on the margo-tree, and the native
girls catch her and her sisters and put
them in baskets, but if left long together
they eat one another, so only a few are left.
Harold: Do they spin much silk?
Sing Spidider 
in box frames, each fastened in by itself, so they can not get away. Then the native girls draw the silk from the spiders' bodies and wind it on reels.

Iva: Is the silk pretty?

Spider: It is the purest yellow, and as brilliant as gold. It is much finer than common silk, and yet so strong that it can be woven into fabrics that will wear for ages. The bodies of these spiders seem to be filled with liquid silk. At an exposition held in Paris some bed hangings made from this wonderful silk were shown. Schools have been started in Madagascar, where many natives are employed to care for spiders.

Glenn: Please tell us about the spider that wears shoes.

Spider: She uses them only when she walks on the water. I keep away from water, but she is never happier than when darting about on the smooth surface of some pond or stream, as you glide over the ice in winter on your skates. Her shoes are tiny bags of air like a toy balloon. She wears them so she will not sink as she scuds through the water. While you are waiting for the water to freeze, she is skating about on her air slippers. You will see her some fine summer day.

Glenn: She must have four pairs of slippers to wear at once. I think father and mother are glad we do not have so many feet.

Harold: What about the spider that makes a raft?

Spider: It lives on the water, too. It takes twigs and grass and ties them together with its silk. On this raft it rides to hunt for a fly for its dinner. If it sees danger near, it hides under its raft.

Hazel: Do not some spiders live in the water?

Spider: Cousin Water-spider leads a strange life. She breathes air as I do, and yet lives in water. She is covered with hairs, which catch and hold the air, and she fills her body 


\section{I46 Friends and Foes in Field and Forest}

with it; then she takes a bubble between her hind feet, and down she goes to her cell.

Harold: What kind of cell?

Spider: She spins one of silk shaped like a cup turned upside down. The open end is toward the ground. When she carries air into the cell, the water is forced out, and she keeps carrying down air till her house is dry. The silk is woven so closely together that the cell is water-tight, and it shines like silver. She spins strong lines which fasten her home to a lily stem or some water-plant. She often lays her eggs on the stem of the plant, and then builds her house near by. Her eggs are a golden color, and are said to be very pretty.

Harold: Her cell reminds me of the divingbell used to recover things lost in the water.

Spider: I think men studied the habits of the water-spider and got their idea of the divingbell from her. Sometimes she is called the fresh-water siren.

Hazel: Here is a little poem I learned about her:-

"On light sprays hung,

By silk cords slung,

O'erarched by a silken dome,

Is the airy hall

With the water-proof wall

Where the siren makes her home.

"By a waving screen

Of emerald green

Her bower is girt about;

But a lucent gleam

From the sparkling stream

Looks in from the world without.

"For a river-sprite, Or a Naiad bright, 
'Twas fit for a fairy queen;

Nay, that pendent cell

Might have suited well

For the boudoir of sweet Undine."

Spider: She carries her eggs about wrapped in a white blanket of the softest silk. Sometimes she weaves a tiny cradle the shape of an egg or a vase, and hangs it in some safe place till the little spiders come out in the spring. Then they are quite able to hunt and spin and care for themselves if they have half a chance.

Glenn: I read that in southern Europe there is a spider that makes her cradle the shape of a balloon upside down, about half an inch long. It has a little door or cover that can be opened; but the mother spider shuts it up tight before leaving it. She hangs the cradle on a bush and leaves it there all winter. Before she leaves, she makes another case outside the one in which the eggs are, and spins silk enough to pack the space between the two cases full, so the cradle is warm and cozy inside.

Spider: Many mother spiders keep their little ones with them all the time, and feed and care for them. While you think us cruel because we kill flies and other insects, yet we love our children dearly. When people try to take away the little cradle in which we carry our eggs, we hold to it with all our might, and will not give it up. When the eggs hatch, the mother spider helps her babies out, feeds them, and tends them as a hen does her chickens. The little ones even climb on her back and ride as you have seen little chickens do. As many as two thousand eggs have been found in one spider cradle. So you see the mother has a large family to care for. Sometimes so many climb on her back that her own body can not be seen. 


\section{BRIDGE-BUILDING SPIDERS}

\section{Hazel: How do spiders build bridges?}

Spider: They climb into trees near the stream they wish to bridge, and spin a long line, which floats out on the breeze till it is caught by some object on the other side. Then Mrs. Spider walks over.

Harold: I wonder what a spider would do if it were placed on a pole in the middle of a stream or pond.

Spider: It has been tried. She first spun a web several inches long and clung to one end, while the other was allowed to float in the wind. I suppose she hoped the web would strike some object, but that plan was a failure. So she waited until the wind changed, and then spun another web like the first, to float away in the opposite direction. She tried again and again until she had sent out a line in every direction. Then she went to the top of the pole and spun a little balloon. When it was finished, she fastened it securely to the pole upon which she was a prisoner, and tested it to see whether it was strong enough to carry her away. Then she took it all apart, and made one which was larger and better. This she did three times. When sure that her balloon was all right, she cut the cord that held it to the pole, and sailed away to land.

Harold: Hurrah for Mrs. Spider! Now I believe the story of Robert Bruce, king of Scotland, who was lying weary and sad in a small house. His army had been scattered by a stronger one, and he thought he might as well give up. Then he noticed a spider trying to fasten her line to the wall near by. As the king watched, she tried again and again, failing every time. But she persevered, and at last the line was fastened in place. The king said if a little spider would not give up when it met so many difficulties, surely he, a big man, could do his work even though he had failed once or twice. He was so encouraged by the example of the spider that he won the victory. 
Hazel: I have heard that spiders tell what the weather is going to be.

Spider: A French general named Disvourjal had been in prison eight years. Spiders came into his cell and made their webs there, and the general watched them and studied their habits. He noticed that when fine weather was coming, they spun a long thread. If it was going to be stormy, they spun short ones. By close watching the general was able to tell when a storm was coming two weeks before it came. The French army came to Holland where General Disvourjal was imprisoned; but the ice and snow began to melt, so the army was in great danger, and those in command planned to leave the country. The general in his cell heard of their plans, and watched the spiders with great interest. He contrived to send a letter to the commander of the forces, in which he wrote, "I pledge my honor that within fourteen days a severe frost will come, which will make you master of the rivers and canals, and enable you to conquer the country." So the spiders were the means of opening his prison doors, and he was set at liberty. This may teach you to store up all kinds of useful knowledge, for sometime you may be able to use it in a way that you do not think.

\section{THE TRAP-DOOR SPIDER}

Spider: Cousin Ta-ran'tu-la, sometimes called the trap-door spider, is very large. Her body is about the size of a pigeon's egg, and is covered with hair; and she has long, hairy legs, so long that she would cover a large plate if placed upon it. She is found in warm countries, as southern Europe, the West Indies, South America, Australia, and in some of the Southern States. She is sometimes called Myg'a-le.

Hazel: Are they all as large as this one?

Spider: No, many of them are much smaller. They are 


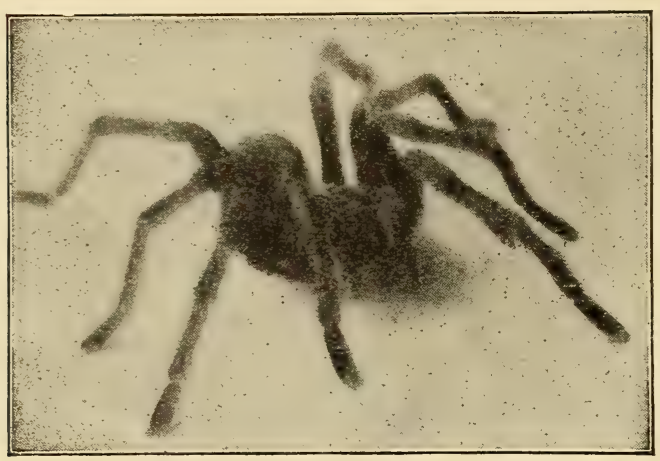

TARANTULA

brown or black, and furry. They are also called wolf-spiders, because they hunt their prey and pounce upon it, instead of weaving a trap and waiting to catch it, as we do. Mrs. Mygale digs a round hole in the ground about an inch across and several inches deep, and lines it with silken curtains which she spins. After that she digs deeper, and again weaves silk to cover the walls. She makes two sets of curtains. The one next to the ground is of coarse brown silk. The inside curtain is woven of the whitest, softest silk. These curtains may be seen in museuıns.

Glenn: How deep into the ground does Mrs. Mygale dig?

Spider: One or two feet. Sometimes the hole is slanting, at other times it slants only a little way, and then goes straight down. She keeps hard at work, and never stops to rest until it is finished. After the house is all done, and the walls covered with silken curtains, she makes a door that fits the burrow just as a cork fits a bottle. It is made of silk and earth like the house itself. She first spins a thick round web, and fastens it at one side by silken threads.

Harold: That must be the hinge.

Spider: Yes. She chooses a sloping bank on which to make her house, and puts the hinge at the highest point, so the door will fall down and close itself. If she wishes it to stand open, she spins a few threads and fastens it open, and at times when she is not leaving home, she spins a lace curtain over the open door, in which some heedless insect is sure to get caught. 
Harold: I should not think the door would be very strong if made only of silk.

Spider: That is only a part of it. After Mrs. Mygale spins the first, or inner, lining, she covers it with sand stuck together with glue. Then she spins more silk, puts on another layer of sand, and finally a top covering of earth, on which she places mosses. and such small plants as grow near. When it is finished, it is as solid as a box lid or a trap-door.

Hazel: Her garden must be small if it is only as large as her door.

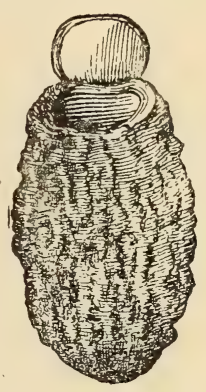

Spider: You would not expect a spider to make a large garden. She has been known to weave pieces of red braid and other fancy materials into her door. If it gets broken, she mends it. Outside it looks so much like the ground that one would not suspect there was an underground house, and a family living comfortably in it. Sometimes Mrs. Mygale makes her house with two trap-doors instead of one, the second being placed in the burrow. house, and if

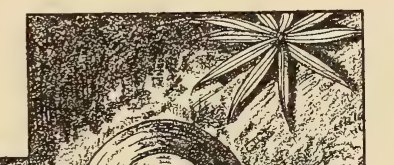
three or four inches down This makes a hall to her an unwelcome visitor comes through the front door, she can close the inner door and her visitor is left in an empty room. Sometimes she $\mathrm{m}$ akes another burrow close to the first, and an opening into it.

Glenn: Does she hang

THE TRAP-DOOR SPIDER

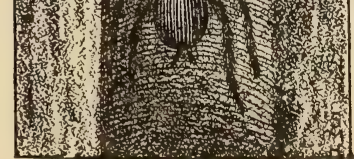
a door between the two?

Spider: Yes; so if an intruder comes through 
both the other doors, she has still another room where she can go and feel quite safe. She goes out to hunt her food at night. When all ready to start, she cautiously raises her trapdoor and peeps out to see that no danger is near.

Hazel: Does she keep her underground house as clean as you keep your web?

Spider: I think so. She eats her meals inside, and throws the scraps out at the door, and afterward carries them away. A gentleman once placed a beetle by her door. The spider took it inside, but soon threw it out again, for it was not the kind of food she liked. Then he put another insect where she could reach it, and she ate that. If she hears anybody near, she speeds to the door, shuts it tight, hooks her hind legs into its lining, and her fore legs into the wall, and hangs on with all her might. Of course such giants as you are would have no difficulty in opening the door, but I think most insects would find it hard to do.

Harold: I should think she would smother in the tunnel.

Spider: There is a row of tiny holes around the outside edge of the trap-door, and another row just inside the top of the tube, to admit light and air.

Hazel: Does the whole family of mygales live in one house?

Spider: Mr. Mygale is left to look after himself mostly, and whether he builds a house I can not say. Mrs. Mygale places her eggs in the lowest room, and cares for the young spiders. She keeps them undẹr her body at first, much as a hen does her chickens. If they try to run away, she pats them back with one of her legs.

Iva: Do the babies make houses with trap-doors?

Spider: Yes, they know how when very young, and make tiny tubes finished with little trap-doors less than a quarter of an inch across. The tarantulas, mygales, mason-spiders, and mining-spiders all make their homes in the ground. Quite a 
number of each family live near together. They are very often found in the nests of termites. There is a spider that builds a hollow tower shaped like a bird's nest. It is made of little stones, grass, sticks, and leaves bound together with bands of silk. This takes the place of the trap-door, and is used to hide and protect the tube, which is twelve, fifteen, or more inches deep.

Hazel: I read of a spider that makes a roof of leaves lined with web, leaving only a very small opening. At some seasons the door is closed to protect those living in the burrow from a wasp which comes to sting them, and take them away as food for its young. The wasp rushes about peering into every hole and crevice, and if the spider neglects to fasten its door, the wasp soon makes it helpless and carries it away.

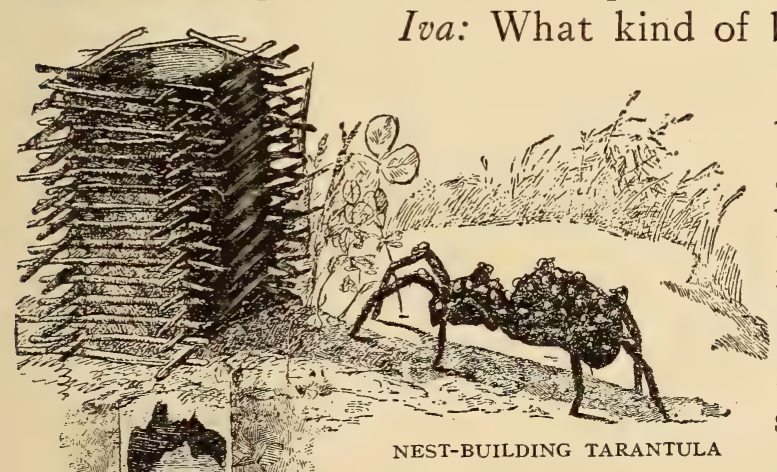

uilding is this one? Spider: It is a tower of sticks that a nother tarantula builds over its burrow. It looks like the houses you make of cobs or sticks.

Harold: The spider looks as if it were covered with warts. Hazel: I believe that those are spider babies, and the mother has been out walking with them. There must be more than forty. There are two on her fore legs.

Spider: I hardly think you have counted right, but there is a large family.

Iva: Please tell us how spiders that live in tents make them. 
Spider: They stick leaves together with silk and glue. Then they lay their eggs on the under side of the leaves. When they hatch, the whole family live beneath their leafy covering. Some spiders sew up the top part of a banana leaf; that makes a cozy home. There is still another that lives in the pineapple. The spines of the plant make a strong support for the web, and also protect the spiders from their enemies.

\section{CURIOUS SPIDERS}

Spider: Some spiders make no houses at all, but just wander about. You might call them tramps, for they live on whatever they find. They can walk backward and sidewise as well as forward. They can also jump quite well. Sometime you may see a small butterfly stay a long time on a blossom. It is dead, killed by a little spider that lived in the flower. The spider waits for insects that come to suck honey. Some of these little spiders are white, some are yellow. The white spiders always live in white flowers, while the yellow ones are found in the goldenrod and other yellow flowers. None of these spiders spin webs, but wait in the flowers till some insect comes their way. Another spider imitates ants, holding up one pair of its legs to look like the antennæ, or feelers, of the ant, and running from one side to the other as an ant does

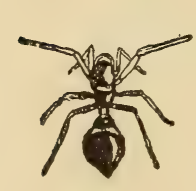

ANT-LIKE

SPIDER when looking for food. The ant goes that way when hunting; but this mimic goes that way all the time. Here is its picture, and you can see whether it looks most like an ant or a spider.

Harold: Why does a spider want to look like an ant?

Spider: There is a bird that has an appetite for spiders for its breakfast, but does not care for ants; so the spiders make themselves look as much like ants as possible, and imitate their actions, so the birds will not molest them. There is a spider 
in Africa that mimics the ants for another purpose. Where it lives, ants and flies visit trees on which they find a sweet sap, and this spider makes itself appear like an ant so that it may steal in among the ants and flies, and while they are busy eating, grab the flies, and thus secure a meal for itself. Glenn: Is there a spider called the harvestman?

Spider: It is better known as daddy-long-legs, because its legs are so long when compared with the size of its body. $\Lambda$ man once watched a harvestman standing in a nest of ants. It kept lifting its long legs, one after another, to keep out of their way, and at one time all but three of its legs were sticking straight out in the air. Spiders like soft and sweet music. At concerts some of my relatives have been seen letting themselves down to listen until the instruments began playing loud; then they quickly climbed back to the ceiling.

Hazel: I read of a spider that lived in a room where there was a piano. When any one was playing, it would let itself down and hang over the instrument; and when the music was finished, it would go back again.

Harold: In St. Nicholas is this story: "Madam Spider was not visible. I knew, however, she must be in her gossamer parlor, which is attached to her web. I rapped a tuning-fork on a stone, and in a moment a soft, melodious hum filled the air. I touched one of the spokes of the web with the fork. On the instant madam flew out of her parlor in great haste, hesitated a moment at the outer edge of the web, and then, instead of going straight to the tuning-fork, ran to the very center of the web. There she caught hold of each of the spokes, and gave it a little tug as a boy does his fishing-line to see if a fish is hooked. Each was passed by until she came to the spoke on which the tuning-fork rested. Then she stopped, and it was easy to see she was excited. She gave the web a shake, then tugged at the spoke again. Hum-m-m-m, still 
sang the fork, rather faintly now, however. Madam was satisfied. Her mind was made up. Down she darted, and caught the end of the fork in her arms. She tried to bite into the hard metal, and at the same time she spun a web of silk around the two prongs, which by this time had ceased vibrating. I pulled the fork away, and Madam Epeira [the garden-spider] retired in disappointment to the center of the web. Probably she mistook the hum of the fork for the buzz of a fly, a sort of music, no doubt, very sweet to her. Time after time I repeated the experiment with the fork, touching in turn each spoke of the web, and each time Madam Spider was deluded into trying to capture the tuning-fork."

Iva: I do not think spiders are pretty.

Spider: Perhaps you would if you saw some wee ones no larger than a grain of sand, that wear bright red dresses. The larger ones are clad in sober colors, brown or black, and many persons think their furry coats are rich-looking. Some kinds have smooth bodies, and wear very little to cover them.

Glenn: Do you and your relatives live a long time?

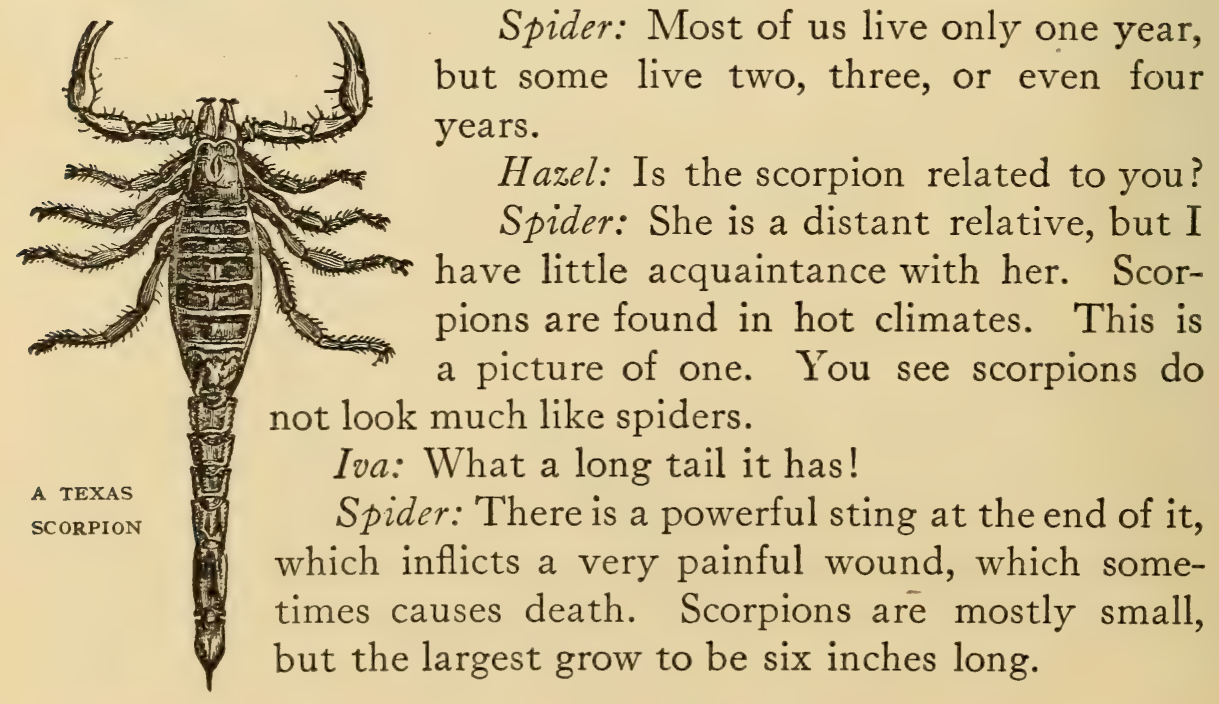

Spider: Most of us live only one year, but some live two, three, or even four

Hazel: Is the scorpion related to you? Spider: She is a distant relative, but I have little acquaintance with her. Scorpions are found in hot climates. This is a picture of one. You see scorpions do not look much like spiders.

\section{Iva: What a long tail it has!}

A TEXAS

Spider: There is a powerful sting at the end of it, which inflicts a very painful wound, which sometimes causes death. Scorpions are mostly small, but the largest grow to be six inches long. 
Glenn: Do the scorpions spin webs as the spiders do?

Spider: No, they do not make homes for themselves, as we do, but live under stones and in other places. Sometimes they get into houses, and hide away in the beds, or in boots and shoes. They can run very fast, and while running wave their long tails to frighten their enemies.

Iva: What do they eat?

Spider: They sometimes steal eggs and eat them, and they like crickets, grasshoppers, and other insects. The mother scorpion carries her babies around on her back till they are able to care for themselves.

\section{PRETTY IS THAT PRETTY DOES}

The spider wears a plain brown dress,

And she is a steady spinner;

To see her, quiet as a mouse,

Going about her silver house,

You would never, never, never guess

The way she gets her dinner.

She looks as though no thought of ill

In all her life had stirred her;

But while she moves with careful tread,

And while she spins her silken thread,

She is planning, planning, planning still

The way to do some murder.

'Tis not the house, and not the dress,

That makes the saint or sinner.

To see the spider sit and spin,

Shut with her web of silver in,

You would never, never, never guess

The way she gets her dinner. 


\section{COLEOPTERA}

\section{Bug or Beetle, Which?}

Iva: See this big bug, Harold!

Harold: That isn't a bug.

Iva: If it isn't a bug, then what is it?

Harold: It's a beetle.

Glenn: But I thought beetles were bugs. What is the difference?

Harold: I do not know what the difference is. Let us ask the beetle himself. Mr. Beetle, are you a bug as well as a beetle?

Beetle: Bugs have a long tube through which they suck their food. In some this tube projects from the upper jaw; in others from the lower, and when not in use it is folded away under the body. Beetles have two jaws and two lips, and chew their food. What you call May-bugs, June-bugs, pinch-bugs, potato-bugs, and tumblebugs are not bugs at all, but beetles. My wings, too, are different from those of a bug.

Glenn: I see you have two wings.

Beetle: Those are not wings. They are wing-cases, called elytra, in which my real wings are folded till I wish to use them. They are hard and horny, and as my wings are thin and delicate, they protect them from harm. They meet together in a straight line on my back, while a bug's wings lap over each other when folded.

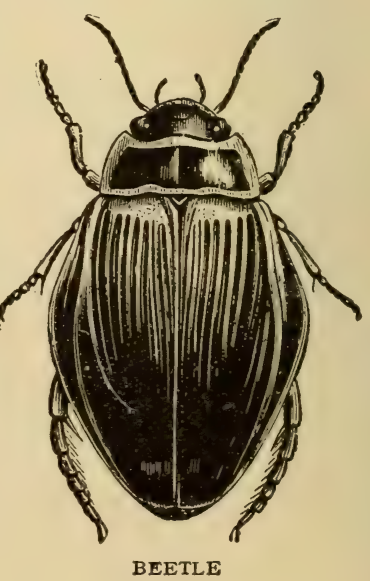




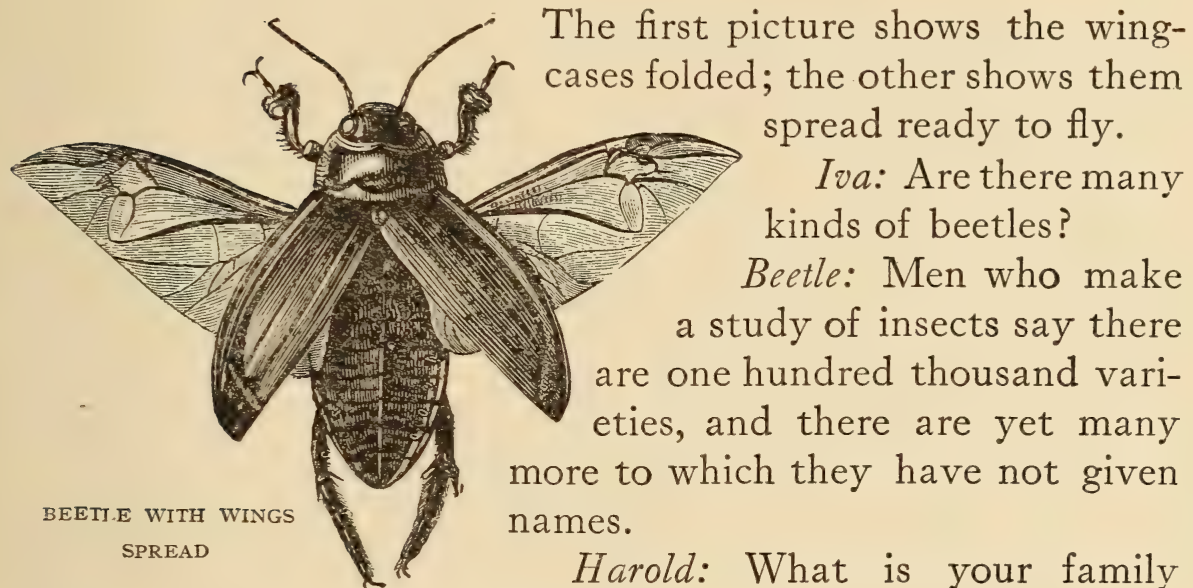
name?

Harold: What is your family

Beetle: Col-e-op'te-ra, which means sheath-wing. The word beetle means biter, and was given us because we bite our food with our strong jaws.

Hazel: Are you like other insects in being larvæ and pupæ before you become perfect beetles?

Beetle: Yes. We have six legs, as they have; we have feelers, or antennæ, and our bodies are divided into three parts.

Glenn: Do you make houses to live in, like the ants, bees, and wasps?

Beetle: We prefer an out-of-door life. Our bodies have such a strong covering that we need nothing more to protect us. Some beetles have such handsome wing-cases that ladies wear them in their hair and as ornaments on their dresses.

Harold: You seem to be clad in armor such as soldiers used to wear.

Beetle: It serves the same purpose for me that their armor did for them.

Iva: Do beetles live on the land or in the water?

Beetle: Both; they are found in all sorts of places.

Harold: And some of them do great harm. 
Beetle: There are others that do much good and are useful to men.

Hazel: What do beetles eat?

Beetle: Many live on plants and in seeds and trees. These are the ones you think do so much damage. Others are your good friends, and kill insects that eat fruits and plants. Some beetles eat animal as well as vegetable food.

Iva: Do you have as many eyes as the fly?

Beetle: Some have more eyes than any other insect. One beetle, and it is not a large one either, has twenty-five thousand eyes. Like the house-fly, it has compound eyes.

Glenn: Do you breathe through tubes in your body, like other insects?

Beetle: Yes; I have no lungs, and do not take in air as you do. Instead, I have breathing holes all over my body, even in my feet, but these tubes are so small that they can only be seen by the aid of a strong glass.

Harold: A r e all beetles about your size?

Beetle: No, indeed; some are so big that they are called giants, and others are so small that they

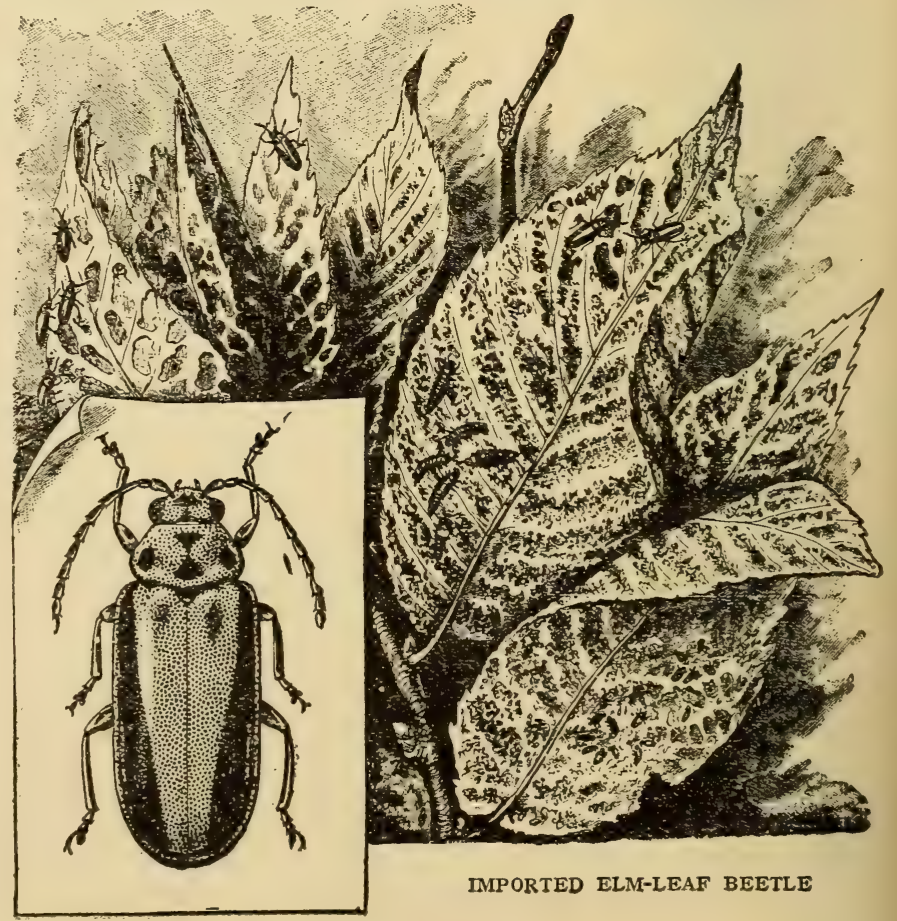


look like tiny dots when placed on white paper, and can only be seen under a microscope. There are thousands of others, all shapes and sizes; some look very ugly, while others are beautiful. There are diving, dancing, jumping, and shooting beetles. Some are like lamps at night; some make oil; some act as undertakers; and some are so fierce and savage that they are like tigers and crocodiles.

\section{The Potato-Beetle}

Mother: Many insects we call bugs are keetles. There was a time when farmers were not troubled with the potatobeetle; I well remember when these beetles visited our early potato-vines. I was a little girl then. They were first seen

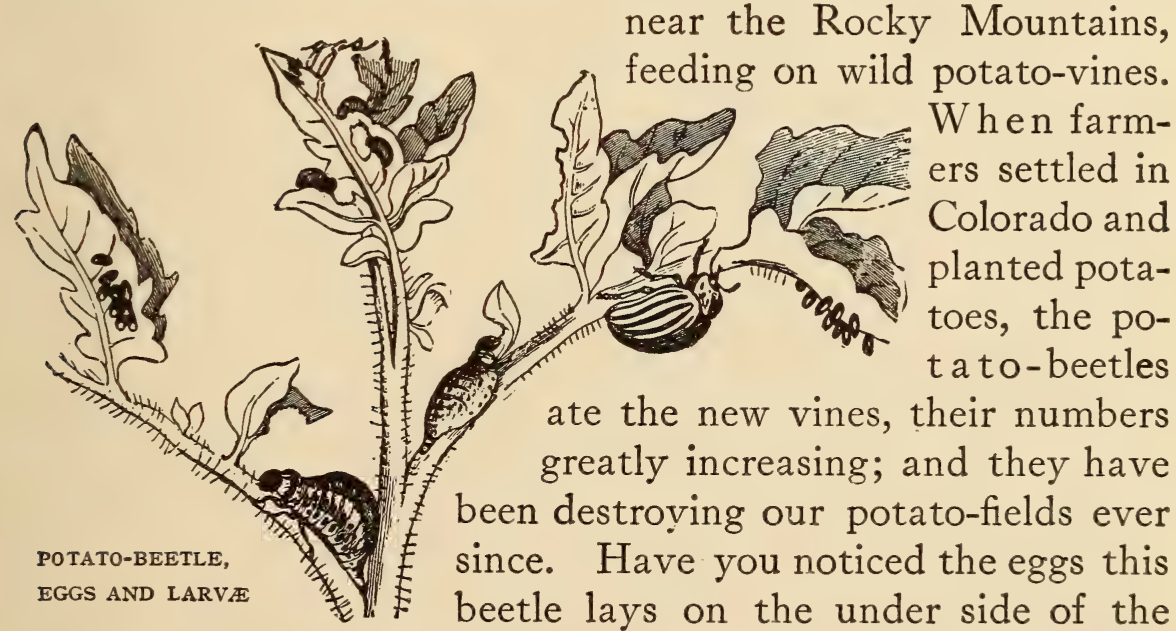
leaves? They are the color of an orange, and there are from twenty to fifty standing on end all in a cluster.

Hazel: What are the ugly-looking creatures on the vines?

Mother: They are the larvæ. The picture shows the eggs, larvæ of different sizes, and the perfect beetle. It takes the eggs but a few days to hatch, and then the larvæ begin to eat 
the potato leaves, and they keep at it until the vines are stripped. They are greedy, and grow fast.

\section{Iva: Do they change to pupæ?}

Mother: Yes, but they go into the ground, where they sleep until they are ready to come out perfect beetles, with brown and yellow stripes on their wing-cases. The next time you see one of these beetles, count the stripes.

Harold: How did they get to the Eastern States?

Mother: They traveled at the rate of one hundred miles a year until they came to the ocean. Then some of them stole a passage over to England and France, and began eating potato-vines in those countries. It takes only a month for the egg to become a perfect insect. The true wings, underneath the striped wing-cases, are a beautiful rose-color.

\section{The Ladybird}

Mother: The ladybird is a beetle. Some call it ladycow, but its true name is Coc-ci-nel'la. You have seen her many times.

Hazel: That little red bug with black spots? I saw several to-day.

Mother: Here is the picture of one flying. You see it has

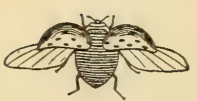

LADYBIRD

FLYING wing-cases and wings under them, like the beetles we talked about. When its wings are folded, they sometimes peep out a little behind, like a white petticoat.

Iva: I saw one which looked as though it cracked open all at once down the middle of its back; and then it flew away.

Mother: It was spreading its elytra, or wing-cases. Notice the spots on the wing-cases. How many do you find?

Glenn: Here is one with ten spots, and one in the next picture has only two. They each seem to have a different number. 
Mother: Different members of the family vary, for there are many kinds of ladybirds. Some are coral red with black spots; some are black with red spots; others are yellow with black spots; and some black ones have yellow spots. One is called the eyed ladybird, because it has red wing-cases on which are black spots on a ring of yellow, looking like eyes. There is one kind that has no spots at all.

Iva: These are pretty.

Mother: They are also useful; the larvæ devour millions of plant-lice, which harm our trees and plants. The mother beetle lays about fifty eggs in a cluster on the under side of a leaf. The larvæ are lead-colored, with bright red or yellow spots, and as soon as hatched they

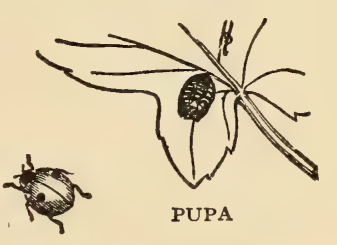
scatter over the tree or plant, hunting for food.

Iva: What do they eat?

Mother: Plant-lice, or aphides. The
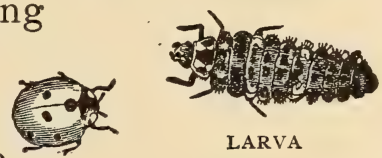

hungry larvæ devour immense numbers of these tiny creatures. They are especially useful where hop-vines grow, and save large sums of money for the grower. They also preserve other plants. Two ladybirds, when placed on two geraniums covered with aphides, cleared them all away in twenty-four hours.

Glenn: Do the larvæ go into the ground to change to pupæ?

Mother: No, they live about three weeks and then pass to some quiet place and hang by the tail to a leaf with their heads down. They become shining black, with a row of orangecolored spots on the back. They remain pupæ two or three weeks, and then become perfect beetles.

Glenn: Ladybird beetles smell bad.

Mother: I suppose that is their way of protecting themselves. 
Harold: Do ladybirds live through the winter?

Mother: Many do. They hide away in sheltered cracks and corners, and sometimes crawl about on warm winter days. Mr. Wood says in some places there are more ladybirds than we should think possible. He has seen the streets red with them; inside the houses they made a band of red along the walls and ceiling, and a big bunch was hanging in each corner. They had saved the harvest of hops that year, and were looking for a warm place to spend the winter. As fast as driven out of the houses, others came in, and were kept alive by the warmth of the fire.

\section{TIGER-BEETLES}

Mother: The wing-cases of tiger-beetles are blue, green, and other bright colors; one is so brilliant that it is called the sparkler. These beetles shine like precious stones. The larvæ wait for prey as an animal does. From the picture you will see how these beetles look. They are about two thirds of an inch in length.

$$
H \text { a r o l d : }
$$
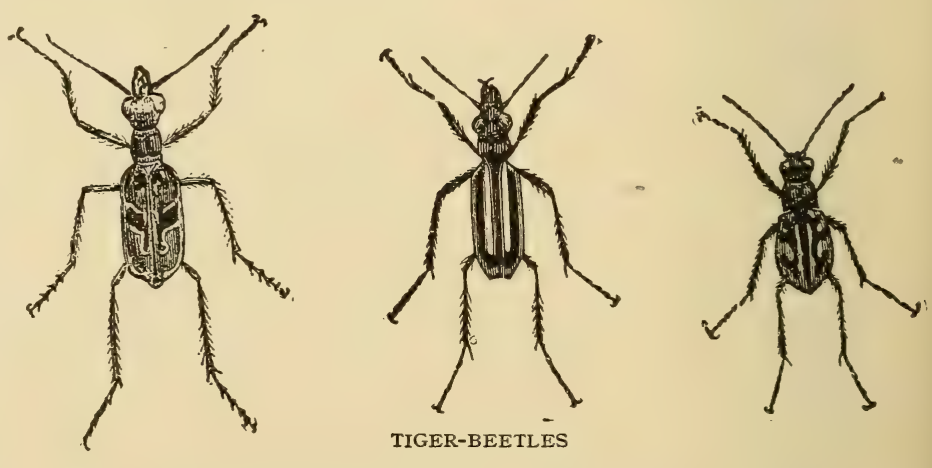

What kind of homes do tiger-beetles have? Do they live in holes made in the ground?

Mother: Yes; they dig the holes themselves, to the depth of more than a foot. They choose light, sandy soil and begin by digging up earth with their jaws and fore legs, placing it on top of their flat heads. When they get a good load, they carry it up and throw it as far as they can from the mouth of the hole, much as the ant-lion does. The ant-lion makes a 
funnel for a trap, while the tiger-beetle forms a chimney or tunnel in the ground. It keeps busily at work, carrying out loads of earth as a mason carries his hod. At the bottom of the tunnel it makes a little room, in which it lives.

Glenn: How does this beetle get its food? Mother: When its tunnel is finished, it goes to the top, fastens itself to the wall by two hooks that grow out of its body, opens its wide, sickle-like jaws, which just fill the top of its tunnel, and there waits until some unsuspecting insect comes along; for in this position it can scarcely be seen. Sometimes it seizes the insect as soon as it touches it; at other times it falls to the bottom in a

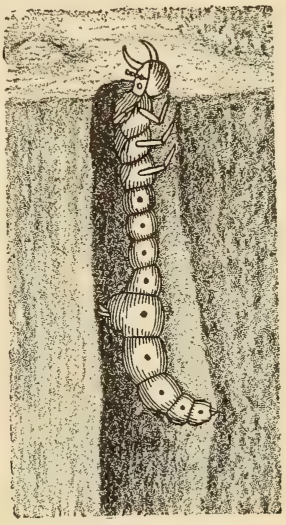

LARVA OF TIGERBEETLE great hurry, and its prey tumbles in after it. It seems always hungry, and looking for something to eat.

Hazel: Do these beetles change to pupæ in their tunnels? Mother: Yes; and very quaint little creatures they are while asleep.

Glenn: Do they hunt when they become perfect beetles?

Mother: Many do, but they also eat other food. They are active, and quickly pack and unpack their wings in their wingcases, flying only a short distance before lighting. They run faster and fly more swiftly than most beetles. Some hunt caterpillars, and will climb trees to find them. If the beetle is held in the hands, the perfume of roses is so strong and pleasant that it seems as if one had handled rose-leaves.

\section{THE BEETLE WITH A GUN}

Mother: The bombardier-beetle is a sober-looking little fellow, with dull-blue wing-cases. It makes its home under a stone in a damp place. It is from one fourth to one third of 
an inch long, and carries a sac of liquid in its body. When pursued by a larger beetle, as it runs to get away, it shoots

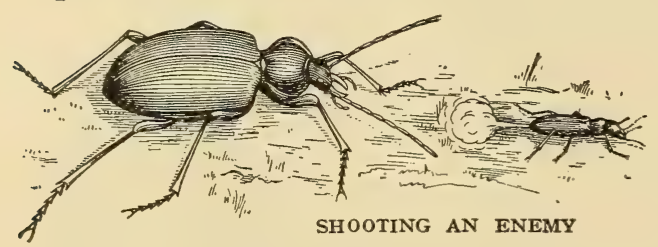
this liquid right into the face of its enemy, which is more scared than hurt; for just as it expects to seize little Bombardier, a cloud of blue vapor pops into its face and eyes. So it runs away. Harold: Can the bombardier shoot more than once?

Mother: Yes, several times. If we turn up a stone where a family of these explosive little beetles live, pop! goes one; and pop! pop! pop! pop! pop! they go, until every one shoots off his little gun to frighten away the big giant that dares to meddle with their home. A dark stain is left on the skin where the liquid hits. Mr. Wood gave one of these beetles a little squeeze after it was dead, and its gun went off as though it were alive.

Harold: If soldiers could do that, so many would not need to go to war.

Glenn: Do other beetles shoot?

Mother: One other, which is quite common in England. It is much like the bombardier, and protects itself in the same way.

\section{JUMPING BEETLES}

Mother: There are beetles which act as policemen for the farmer and gardener. Their family name is Car'a-bus, but there are many different kinds. This picture shows how one of them looks. They have long legs, strong jaws, and large eyes. They are all brave, swift, and strong. They live under stones and the bark of trees, but may often

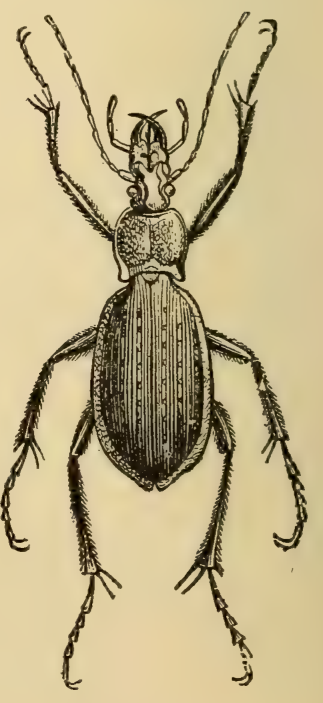

JUMPING BEETLE 
be seen in fields or roads hunting for caterpillars and other pests that destroy crops. Many wear uniforms of green, blue, and gold. Those that wear the brightest colors are found in Siberia, Italy, and China. They never steal from the farmer, and their whole business is to destroy thieves. They work for us all the time and ask no pay, except the body of the thief, which they soon land safely in jail, which is found inside their own bodies.

Glenn: They must be like a cat in the granary or toads in the garden.

Mother: There is another beetle of which you will like to hear. It has a number of names, but is best known as skip-

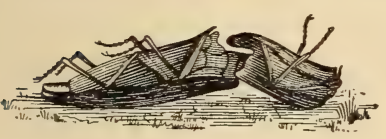

JUMPING ORGAN OF THE ELATER, SEEN SIDEWISE jack, snap-beetle, spring-beetle, and clickbeetle, though its proper name is $\mathrm{El}^{\prime} \mathrm{a}$-ter, which means elastic. It has a long, slender body, and short legs. Some of these beetles are very small, and others are an inch and a half long. One kind has two big black spots on its gray back that look like eyes. When these beetles fall on their backs they can jump several inches into the air, and generally come down on their feet.

Hazel: How can the Elater jump when it has such short legs, mother?

Mother: It has a spring in its body. When it falls on its back, it begins to kick and tries to get on its feet. If it fails, it lies quiet an instant, but presently it springs into the air. If it lands on its feet, the performance is over; if not, it jumps again and again till it succeeds. Sometimes it seems to get angry if it fails the first time, and then jumps five or six times without stopping. If not on its feet after so much effort, it stops to rest awhile, lies perfectly still, and then tries again. While lying on its back, it rests its weight on its head and on the tip end of its body, as you see in the picture. Then it 


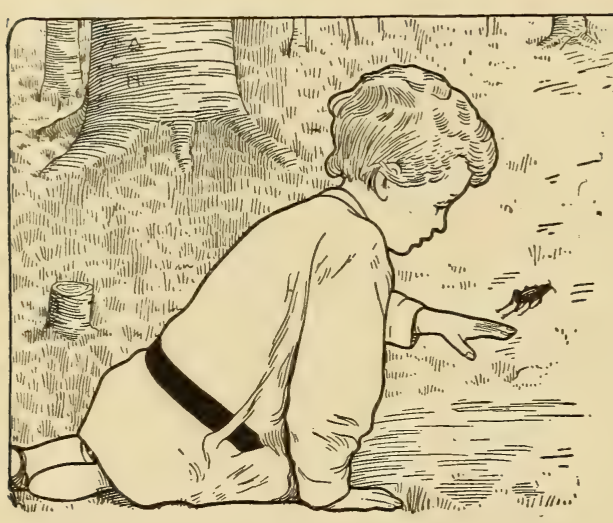

"LOOK AT It!"

suddenly unbends with a click and spring, and up it goes into the air.

Iva: $\mathrm{C}$ an the larvæ jump?

Mother: No. They are called wireworms, on account of their long, narrow shape. They do much mischief by eating off the roots of growing grain. They bore into potatoes, beets, and other vegetables. They remain larvæ five years. Children sometimes gather and destroy them on account of the harm they do. One boy collected eight hundred wireworms in one afternoon.

Glenn: Are there any more jumping beetles?

Mother: There is one more name, Or-ches'ti-a, which means jumper. If turned out of its home, it hops about in a funny way like a flea. It has long hind legs like a grasshopper. There are about five hundred different kinds of click-beetles.

\section{Night-Lights in the Meadow}

Hazel: See! it looks as if the grass were full of moving stars.

Glenn: Those are fireflies, Hazel.

Mother: We call them fireflies, but they are little beetles that carry a light wherever they go. They belong to the same family as the jumping beetles. Another name given them is glowworms, but they are neither flies nor worms. Run out, Harold, and see if you can catch one of these little night-lamps for us to study.

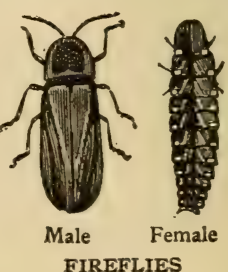

FIREFLIES 
Harold: Here are two, mother.

Iva: Did they burn your hand, Harold?

Harold: Not a bit. I think they must carry cold fire; for I felt no more heat than if I had been holding a common fly. Mother: The room is dark now, so we can see them better. The wing-cases are not so hard as those of most beetles. This one is a female and has no wings at all, while the male has rather large wings, and soft, long cases to cover them. His light is not so bright as that of his mate; some people think he carries none at all.

Harold: What makes the light? It seems to come from the under side of the body.

Mother: It is produced by the slow burning of something inside of the body; of what, we can not tell. The name of this beetle is Lam-py'ris, which means shining tail, because the light is in the hinder part of the body. If the insect is placed in oxygen gas, it gives a brighter light, as it does when excited.

Harold: Do the larvæ shine, too?

Mother: Yes, and even the eggs glow with a soft, greenish light. The larvæ are useful in devouring young snails, which would eat our vegetables. The little fellows move into their shells, and have a queer way of stopping up the door with their old skin when they change to pupæ. Here is a picture of a beetle which gives light from two bright spots on its thorax. It is found in South America. It is called the lightning Ela- uightmiñg elater (cucujos) ter, though the Spanish people give it a different name, cucujos.

Glenn: Do these beetles give more light than our fireflies? Mother: Much more; one can even see to read by their light. At night they may be seen in great numbers sparkling 
amid the leaves of trees, where they "flitter, flutter, wheel and reel, turn and burn," all through the hours of the night.

"Among the choked lanes, on every hedge,

The glowworm lights his gems; and through the dark

A moving radiance twinkles."

Harold: I should think that one of them might serve very well as a lantern.

Mother: Travelers use them that way, and in the hot countries where they are found, one would hardly travel at night, where there are so many snakes and reptiles, if it were not for their friendly light. Sometimes they are fastened to the boots, and sometimes held in the hands. When no longer needed, they are carefully placed on a bush or shrub, to go where they please. The Indians use them to lighten their huts, and women wear them as ornaments. They are put into gauze bags and fastened to the hair or dress. After being worn, they are put into tiny cages, fed on sugar-cane, and bathed twice each day to keep them alive. All fireflies live in damp places; the cucujo must have plenty of water. If it is tired and thirsty, its light becomes pale and dim.

Iva: What is this picture?

Mother: It is the stag-beetle.

Glenn: Does it have that name because it has such large horns?

Mother: I think so; and also because they look like those of some deer that have wide, branching antlers. That which you call horns are the beetle's jaws. Though it looks so frightful, it would not bite unless you should try to hold it in your hand. The stag-beetle is

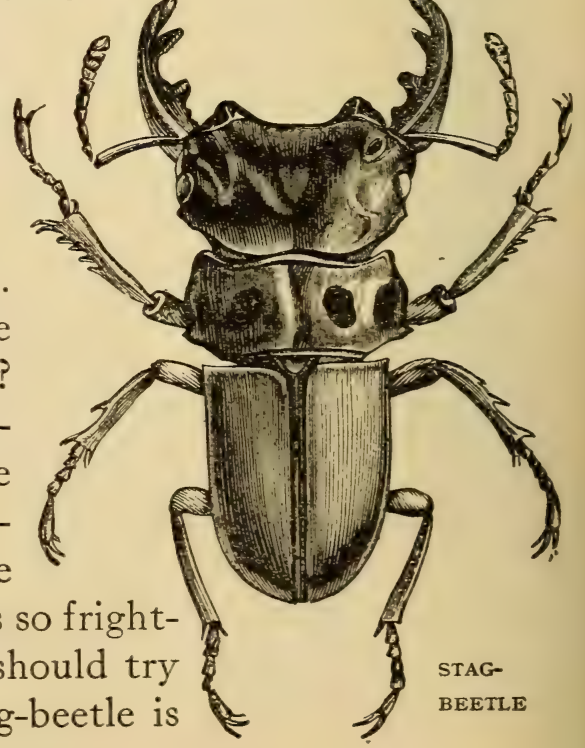


one of the largest beetles we have in this country. These beetles are sometimes nearly three inches long, though they are often found not half that size. They are so large that they can not fly so well as other beetles. They fly only in the night, and hold their bodies very straight. The head and thorax are black, the wing-cases dark brown shaded to black at the edges, and the jaws are brown also. In the months of May, June, and July they may be seen hooked to forest trees by their mandibles.

Glenn: What do they eat?

Mother: A kind of honeydew found on oak-trees, and they also eat the leaves of the oak and willow. Swedish people call them the $e k$-oxe, which means the oak-ox. I read of a man who kept one as a pet. It would follow him about like a dog if he offered it honey. They have been seen eating insects, too. They have curious feelers, like the teeth on a comb.

Glenn: Where do the larvæ live?

Mother: The mother stag-beetle lays her eggs in the rotten wood of oak-trees. When the larvæ hatch, they eat the bark, leaves, wood, and roots of the trees, and their jaws are so strong that they sometimes do much harm; for, like all beetle larvæ, they are great feeders.

Harold: How long do the beetles remain larvæ, mother?

Mother: From four to six years. When ready to change to pupæ, they make a case of the chips of wood from which they have sucked the juice, and stick them together with glue from their mouths. Should you visit the South Kensington Museum, in London, you might see a cocoon made by the pupa of a stag-beetle, from which the top is removed like the lid of a coffin, showing the beetle inside. Mrs. Stag-beetle has a smaller head than her mate, and has no horns.

Iva: I saw some beetles rolling a ball to-day. It was as round as a marble, and about the same size. There were three 
or four working with all their might to roll it. What kind of beetles are they? Harold: Those were tumblebugs.

Mother: Their proper name is scarab. There is a large family of them, and some have strange shapes. Their ball rolling is a serious matter to them, and they work very hard to get it to some hole where they can bury it. Inside the ball is an egg hidden by the mother beetle. The papa beetle helps her roll the ball along, and they pull and push together with all their might.

Iva: The ones I saw to-day

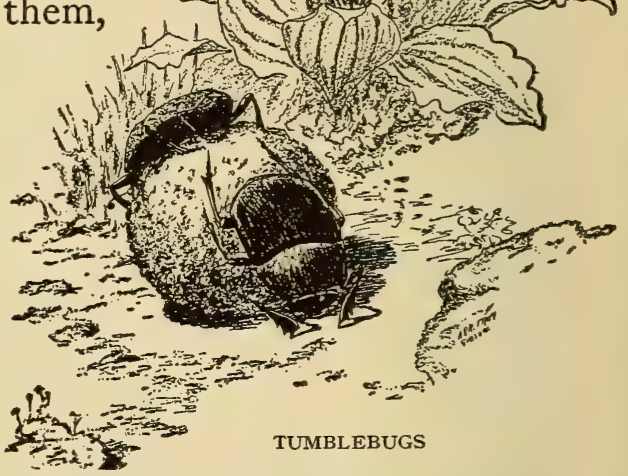
rolled theirs up a little hill, and it rolled away again, and they rolled down with it.

Mother: That often happens, but it never discourages them. They work all the harder to get the ball to the place they wish to bury it. Sometimes, when they find the load too heavy, other beetles help them. The mother beetle has no care for her children after she leaves the eggs in the right place. She places food enough in the ball to last the baby till it is able to provide for itself. The balls are not round at first, but become hard and round by being rolled about. These beetles are sometimes called pill-makers, because their balls are shaped like pills.

Harold: These tumblebugs must be very nimble in using their legs.

Mother: The hinder ones are set far back, and are long, too. This makes it hard for the beetles to walk, and they may often be seen going backward, and tumbling head over heels. In 
Egypt this beetle is worshiped as a god. Here is a picture of Khepera, a form of the Egyptian sun-god. He has the body of a man, the tail of an ox, and a head made in the form of $\infty$ a beetle. This is the way his 4, name was written. The EgypNAME KHEPERA tians thought the egg-ball of the IN writing beetle and a dead human body were alike, in that each was made of decaying matter, and each contained a germ of life. They saw that living beetles came from the egg-balls, and they believed that a spiritual body would come from the dead human body; so Khepera was thought to. be the god of the resurrection. As the beetle was a part of him, it became a symbol of the god, and a type of the resurrection.

Glenn: I read that models of beetles were buried with dead bodies in Egypt.

Mother: The Egyptians thought the

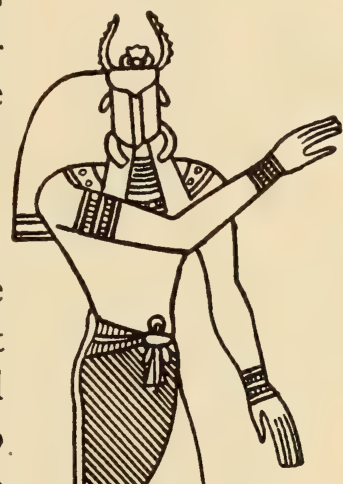
beetle had given the germ of life to its eggs, so an image shaped like a beetle would give life when placed near a dead

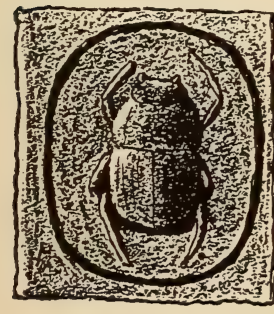

EGYPTIAN SCARAB body, if certain words were written on it. Living people also wore images of beetles, called scarabs, as ornaments. Scarabs of every form and kind have been found in Egypt, and thousands may be seen in the British Museum. Mummies have been found with scarabs wrapped in with the cloth enclosing the body, lying about loose in the coffins, and even in shallow holes under the coffins. In one tomb thousands were found, placed there to make sure that the body would have a resurrection. 


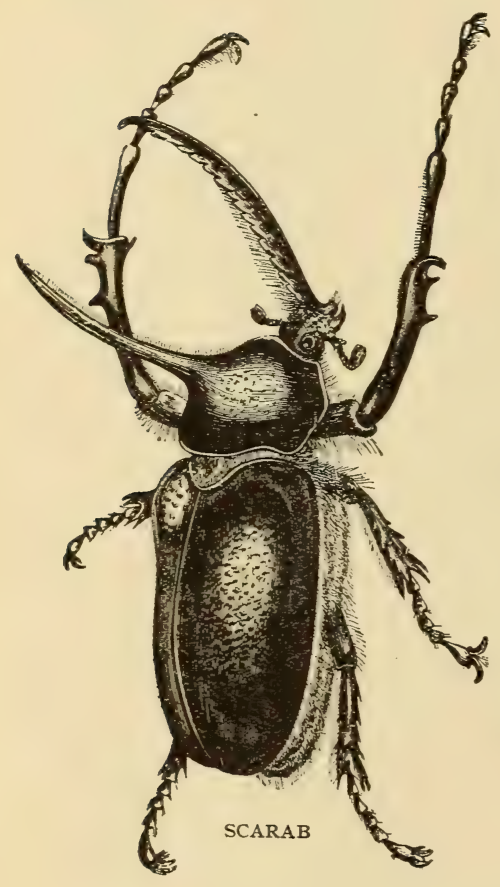

Harold: If the Egyptians had remembered that only God can give life, and that he placed it in every tiny insect's egg, they would not have trusted in the image of a beetle to bring their dead friends to life, nor have worshiped the insect.

Mother: And they would not have worshiped the sun had they remembered the fourth commandment; but they forgot God's day and God himself. They became sun-worshipers, and then began to worship oxen, frogs, beetles, and many other creatures.

Hazel: Did the Egyptians have any other use for the scarabs?

Mother: They made some large

ones, two or three inches long, and even larger, on which they wrote things they wished to remember. King Amenhotep had written that during the first ten years of his reign he shot with his own hand one hundred two fierce lions. Scarabs were also used as seals and worn on rings. From them men have learned many events of history which took place thousands of years ago. Undertakers kept them to sell. Sometimes they were placed on the breasts of mum-

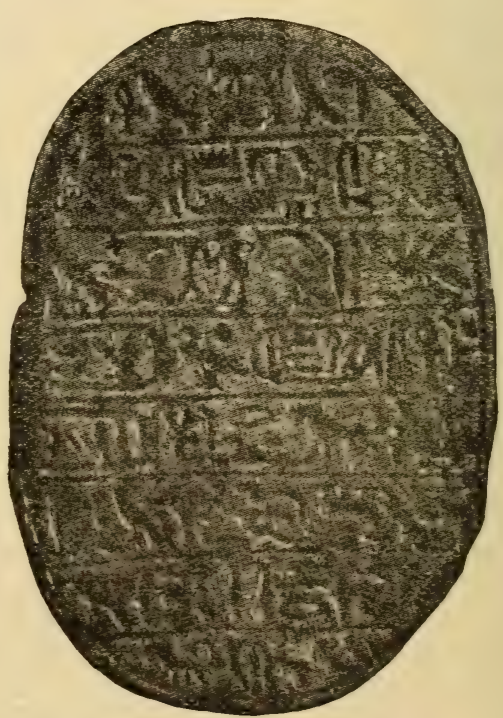

SCARAB OF AMENHOTEP III 
mies, or even inside the bodies of the dead to take the place of the heart. On one scarab in the British Museum is found a prayer asking for a boat in which the dead person might sail; that her eyes and ears might be given her; and that she might see the land of the gods. Some of these were made at the time of King Pharaoh.

\section{Giant Beetles}

Mother: There are more than three thousand different kinds of beetles in the family to which the Egyptian scarabs belong. They are divided into six general classes. One class is of use because it eats decaying matter, which would make the air impure. To this belong the tumblebugs. One kind lives on flowers, and still another delights in eating honey. Another class eats leaves; and another is skilful in boring into wood, where it makes its home. These last are the giants among beetles, as Goliath was a giant among men.

Iva: Is this a picture of one of them?

Mother: Yes; and it is life-size. These immense beetles are sometimes five or six inches long, but are quite harmless. Mrs. Goliath is not quite so fierce-looking as her mate. They are found only in hot countries. They are often seen in museums, and two hundred dollars has been paid for a single beetle; but they are now more common.

Hazel: How are they caught?

Mother: When seen fluttering about the tops of trees, hunting flowers for food, the trees are felled, or the beetles are shot with sand, to bring them to the ground.

Glenn: Do they eat wood?

Mother: Their larvæ do. It is well for us that they live in tropical countries, where there is plenty of timber on which they can work. 
Friends and Foes in Field and Forest

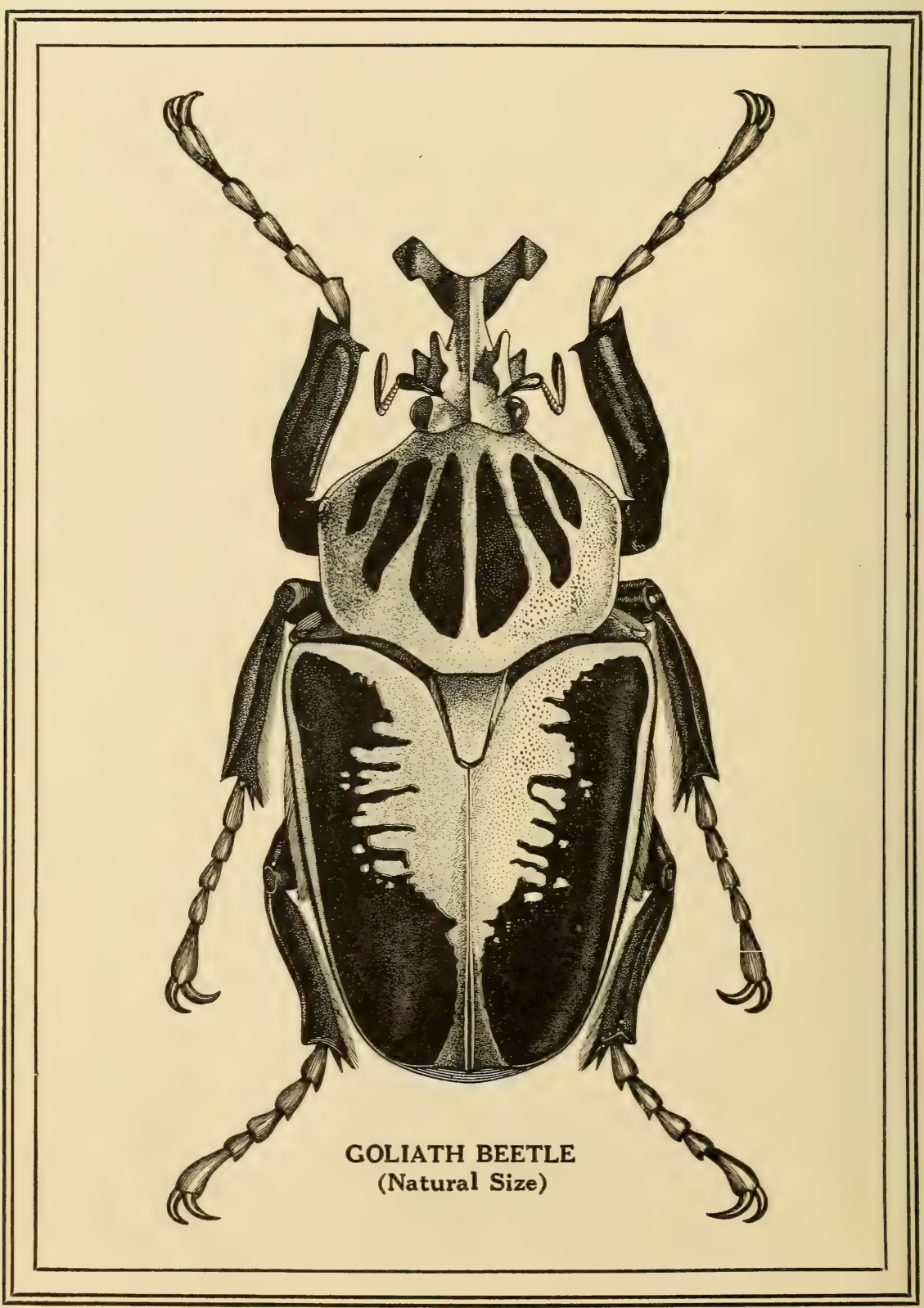


Iva: What color are they?

Mother: Bright green, yellow, and other colors. The one in the picture is found in Sierra Leone, on the west coast of Africa. Giant beetles are also found in Brazil.

Iva: What are the beetles in the picture doing, mother?

Mother: They have found a dead mouse, and are going to bury it. They are sexton- or burying-beetles, and their business is to bury out of sight any dead body that may be found.

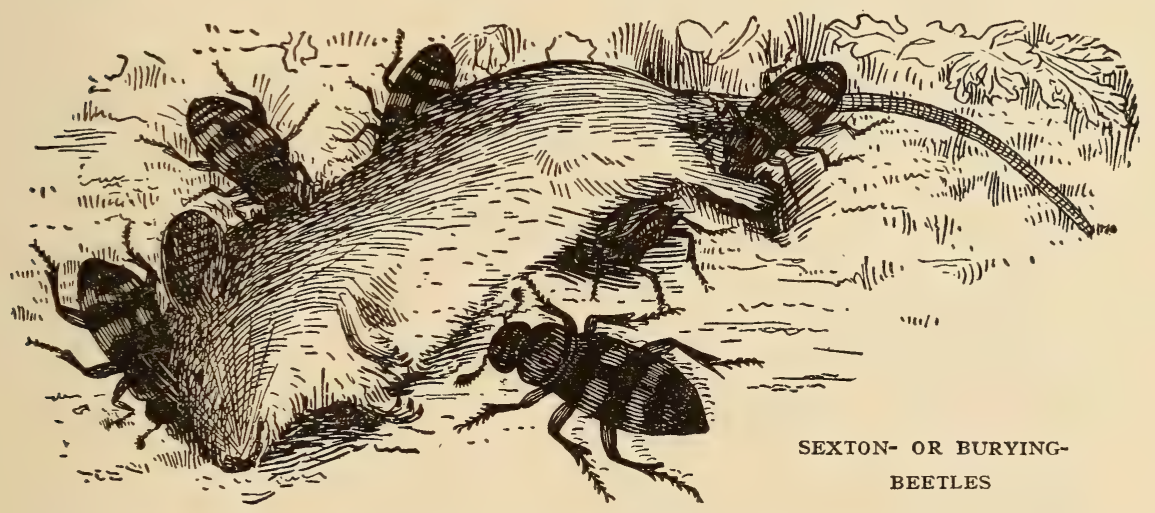

They have a strong, unpleasant smell, caused no doubt by their contact with the dead, and by the food they eat; but their bodies are covered with a kind of oil that keeps their coats from becoming soiled. They are never more happy than when they find some carcass to cover with earth. Mr. and Mrs. Sexton always go together when looking for a job of this kind. When they find a dead body, they walk all around it, stop, and plan how they can best get it into the ground. Perhaps other sextons happen along, until there are a large number to attend the funeral of Mr. Mouse. They first eat all they wish of the dead body; for the sextons are flesh-eating beetles. Then Mr. Sexton begins work, while the others look on. He plows a little furrow around the dead body with his head. He works awhile, stops for rest, then works again, plowing deeper 
and deeper around and under the body. If the ground is very hard, they drag the mouse to a place where the grave is easier to dig.

Harold: I should like to fasten the body with a string, and see what they would do.

Mother: A stick was once run through a mouse, thus firmly fastening it to the ground, and the body was also tied with a string; but the sextons dug around the stick and loosened it, and cut the string.

Glenn: Do they really dig a grave deep enough to bury the mouse?

Mother: Little by little the body settles into the ground, until it is buried from seven to ten inches deep. It is slow work, but they keep patiently at it, digging, tramping, pressing, pushing, pulling, for they have no tools but their heads and feet with which to work.

Glenn: How large are sexton-beetles?

Mother: About an inch long.

Hazel: Do they do all that work just to get the dead mouse out of sight?

Mother: No, they have a very different purpose. They are making a home for their children, and laying up stores of food. When the grave is deep enough, they throw the loose earth in so the mouse can not be seen. Mr. Sexton makes a side doorway, or tunnel, into the grave, and Mrs. Sexton goes in and leaves some eggs. After both beetles have eaten all they wish, they come out and fly away to find other things to bury.

Harold: Mother, how long does it take the eggs to hatch?

Mother: About two weeks. The body of the mouse provides the larvæ with food until they change to pupæ. When ready for this change, they go deep into the ground to sleep and rest, 


\section{THE SHORT-COATED BEETLES}

Mother: There is a family of beetles whose wing-cases look as if they had been outgrown; but we know this can not be, for all insects are full grown soon after they leave the pupa-case.

Harold: This one looks as if it had on only a waistcoat or a vest instead of a coat.

Hazel: Are their wings longer than the cases that cover them?

Mother: Yes, the wings of all the members of this family are large, and though we should think it hard to fold and unfold such big wings under such small cases, yet

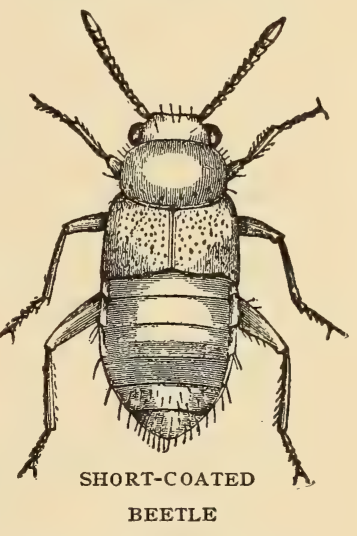
these beetles get ready to fly in less time than most others. When folding their wings, they bend their tails over their backs, and use them as a help in putting the wings into the cases. On account of this habit they are called cocktailbeetles. They look like flies because they have such broad wings and fly so quickly. Many of them are very small. They are what we call little black flies, the ones that try to get into our eyes on summer evenings.

Harold: If they turn up their tails when they get under our eyelids, it is no wonder they hurt.

Iva: This one looks as if it were trying to stand on its head.

Mother: That is a strange beetle, common enough in England, called the devil's coach-horse. It belongs to the shortcoated family. It is very black, and when its tail is raised, it looks like a scorpion. It can not sting, but has such a bad odor that one does not care to go near it. Its odor was no doubt given it to protect it from its enemies. It is always ready for a fight. Mr. DEVIL'S COACHHORSE Wood once found one of these beetles at the foot 
of a flight of stairs. It did not seem at all afraid; and when Mr. Wood shook his cane at it, it dashed at the cane with open jaws; and it followed him to the very top of the stairs, angry, biting, seeming not at all afraid of man or cane.

Harold: There seems no end to the beetle family.

Mother: We have talked of only a few kinds, and in each of these families there may be thousands of different varieties.

\section{The Weevil Family}

Hazel: See the holes in these beans, mother. I find a great many in them.

Mother: You would hardly think such a tiny hole could be the home of a beetle. It was made by a little weevil.

Glenn: I found some in the peas, too, when I was looking them over.

Mother: Here is one alive in this bean. Not only peas and beans, but wheat, corn, rice, and all kinds of seeds and fruits that we use as food, are chosen by the weevil family for their food as well, for they are all vegetarians.

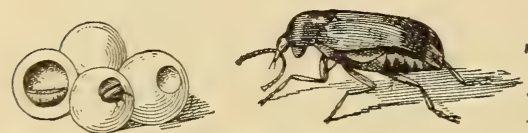

PEA-WEEVIL

Weevil: We are a large family. There are more than five hundred kinds of weevils known in England alone. There are so many of us that it is not known just how large the family is. We live in wheat, corn, rice, peas, beans, turnips, asparagus, apples, pears, plums, nuts, and, in fact, any kind of grain or fruit. We eat roots, stalks, leaves, flowers, and fruit.

Harold: I read that about two tons of weevils were sifted from one hundred forty-five tons of corn. How do weevils get into seeds?

Weevil: The mother weevil lays an egg in a kernel of wheat or some other kind of grain. When the larva is hatched, it 
finds itself living in a house made of food, and it loses no time in beginning to eat. It never eats the outside of the house it lives in so the grain appears all right. Here is a picture of my cousin the pea-weevil. It is taken large so you can see the shape of weevils.

Iva: You have a trunk almost like an elephant's.

Weevil: It is shaped some like it, but it is a snout or beak, not a trunk. It is hard and horny. With it I dig out my food, and it is also used to bore in wood or bark. We are shaped some like the ant-bear, only we are such wee creatures that it takes more than a dozen to measure an inch. Some are so small they are called fleabeetles. We are much larger in hot coun-

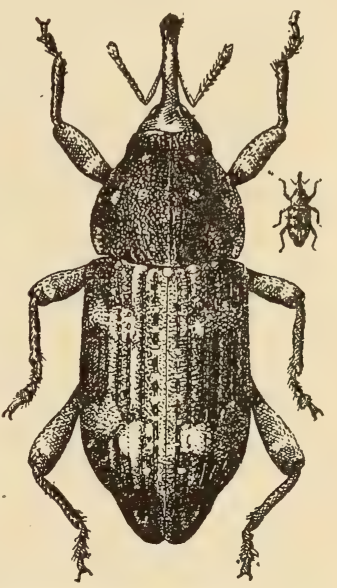
tries, as are most insects. There is a wee- Pea-weEviL-endarged vil in South America that lives in palm-trees. It is black, and about an inch and a half long. Its larvæ grow two or three inches in length, and the people of that country fry and eat them.

Iva: Are weevils bugs or beetles?

Weevil: All weevils are beetles. Most of them wear dull colors, though some, like the diamond-weevil of South America, are golden green and as brilliant as gems.

\section{WONDERFUL WEEVILS}

Weevil: One family of weevils make their houses in the fat sides of turnips. The mother weevil lays her eggs under the rind, and warts, or galls, grow out, in which the larvæ live. They do little harm, and are only one eighth of an inch in length. On the next page is a picture of a weevil as it climbs a stalk of wheat and eats the tender grain when hait 


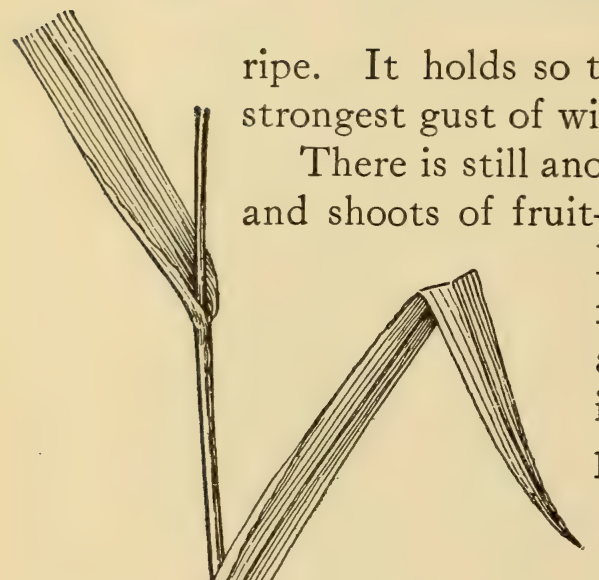

ripe. It holds so tightly to the wheat stalk that the

There is still another weevil that works on the grafts and shoots of fruit-trees in a way the farmer does not like. It bores into the center and makes a little room, where it leaves an egg, pushing it into place with its beak. Then it climbs below the place where the egg is laid, and cuts the stalk part way off, then climbs up so its weight will make the stalk fall over. If it does not fall at first, it goes back and cuts deeper, then tries again, until it falls, as in the picture. As it lays two eggs a day and keeps cutting off shoots for several weeks, it does quite a stalk-Boring little damage to the farmer's trees.

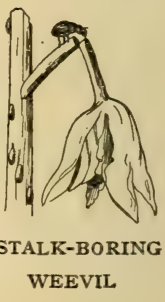

Iva: Do weevils eat flowers as well as wheat and other grain?

Weevil: They do; one kind works in apple blossoms. As the bud is ready to open, the mother weevil makes a hole with her long, slender beak, and weEvil cumbing places an egg inside the bud, so it never opens nor - bears fruit, but looks as if it had been burned. But what could be more dainty than to lie in such a sweet bed, with apple-leaf blankets tucked closely about the little one, who eats and sleeps there? The mama weevil can not fly, and she lives under moss or bark most of the year. If you want good apples, do not let moss grow on the trunks of the trees. A ring of tar will help to keep the apple-blossom weevil away. There is a weevil that lives under the bark of apple-trees and bores tunnels into the wood. It is called the apple-bark weevil. 
The plum-tree borer works in plum-trees in much the same way.

Harold: Does the weevil eat plums, too?

Weevil: Not exactly; but it might as well. It eats halfway through the stalk, then pierces the fruit, and beside the hole leaves an egg, which it presses in to the fruit with its beak. Then it eats the stalk nearly off, so it falls to the ground. This picture shows it at work, and also shows the larva and pupa.

Harold: Isn't there a weevil called curculio that eats into plums?

Weevil: There is a whole family of curculios. Some eat apples; others like

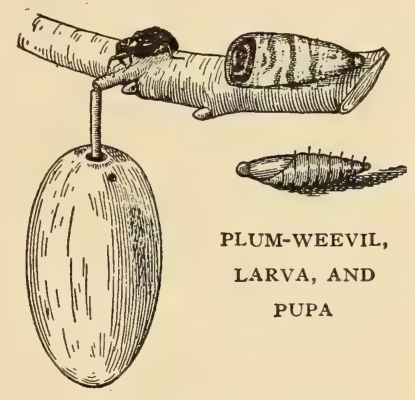
plums; still others choose apricots, peaches, and other kinds of fruit; and others eat nuts.

Iva: How can a worm with its soft body get into nuts, when they have such hard shells?

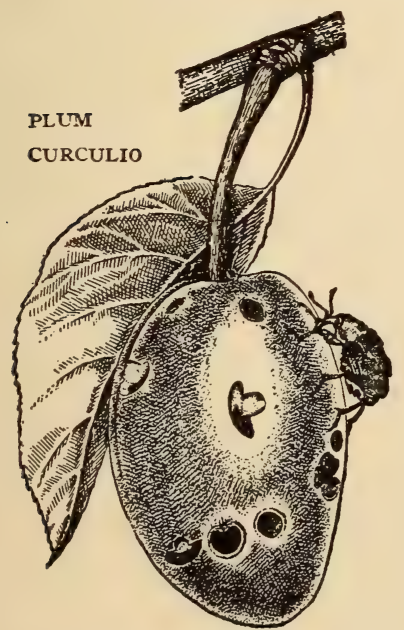

Weevil: The shells are not always hard. While the nuts are green and tender, the weevil bores a hole with its long beak, puts an egg inside, and the opening soon closes. As the nut grows, the larva eats the kernel, and when ready to turn to pupa, it eats a hole through the hard shell and crawls out.

Harold: I read about some jumping beans that grew in Mexico. When placed on a table, they kept hopping about. There was a little worm inside about the size of hazelnut larvæ. It lives in the bean from August to May, and keeps jumping all the time. The egg was laid in the flower, and there was not even the tiniest spot to show how the worm got inside the 
bean. The writer said the beans looked more like nuts than beans. I wonder if these worms were weevils.

Weevil: There is a little weevil that lives on the mustard plant, and eats nothing else. It eats holes in the leaves, and

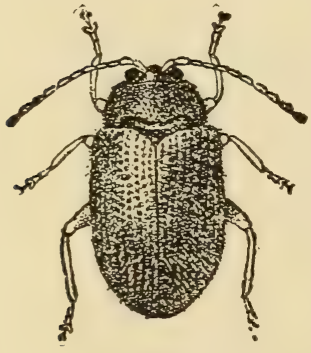

POTATO FLEA-BEETLE often only a skeleton of the plant is left standing. There is also the acorn-weevil, which eats its way into acorns. Almost every kind of fruit and grain has its weevil. Some are no larger than an exclamation-mark, while others are over an inch long. They feed on grasses, clover, thistles, seeds, grain, roots, leaves, bark, blossoms, and fruit. Some wear sober colors, and others are covered with bright scales as fine as dust. One of the prettiest is so small that a thousand could be put into a thimble. Some kinds are so numerous as to destroy fields, vineyards, and forests.

Hazel: I should think the birds would eat many weevils.

Weevil: When we are in danger, we fall down as if dead, and roll ourselves into little balls, which look like gravel-stones or earth-balls.

\section{The Merry Dancers}

Glenn: See how fast those little things go on the water. Now they are all gone. They must be divers as well as dancers.

Harold: I have caught one in my net. I believe it is a beetle; for it has horny wing-cases. Perhaps we can coax it to tell us its story.

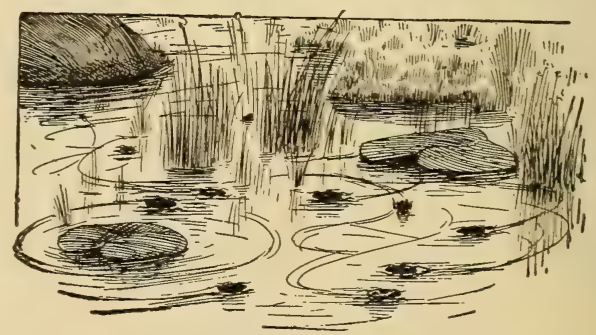

WHIRLIGIGS 
Whirligig: My proper name is Gy-ri'nus na-ta'tor, though I am called whirligig and whirlwig, because I dance about on the water.

Harold: Why do you dance about so?

Whirligig: I am hunting my food. I am the size of an apple seed, and my body is shaped like a boat. My hind and middle legs are like the long front legs are much head is quite small, and are above, and with things in the air; half down into the water. might try to seize me

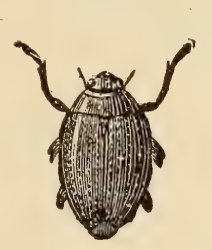

GYRINUS NATATOR fins of a fish, but my like your arms. My I have double eyes; half them I can look at are below, so I can look As I dance about, a fish from below, but I can see it coming, and jump out of its way; or if a bird darts down from above, I can see it and dive into the water.

Harold: Are you dancing about looking for something to eat all the time?

Whirligig: No; sometimes a number of us get together and have a game of tag. We frisk and freak, skip and skim, wheel and whirl, curve and curl, with very joy because we are alive. We have pads on our feet, and the hairs on the pads catch and hold tiny bubbles of air.

Iva: Can you fly as well as dance?

Whirligig: Certainly. When we get tired of one pond or creek, we fly away to another.

Hazel: Please tell us about baby whirligigs.

Whirligig: Mother Gyrinus lays her eggs in two neat rows on some water-plant, and they hatch in about a week. At the end of summer they come out and spin a little cocoon in which to sleep while in the pupa state. In a month the perfect Gyrinus is ready to live. It plunges into the water, and there spends the rest of its days. In winter we stay in the mud among the roots of plants. When the weather is warm, we 
come up to the surface to enjoy the sunshine, and to have a game together.

Iva: Are all whirligigs as small as you?

Whirligig: Most of us are small, but in tropical countries there are some an inch long. Some prefer to live where it is aways cold, but I like this pond.

\section{GIANT WATER-BEETLES}

Glenn: Here is a beetle we have not seen before. Tell us your name, please.

Beetle: My true name is so long I do not believe you would remember it half a minute. It is Hy-droph'i-lus, but $\mathrm{I}$ am also called the great water-beetle. I am the largest water-beetle known, being nearly

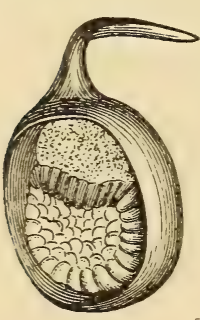
EGG-CASE OF WATER-BEETLE two inches long. My mother is a spinner, and she spun a little water-tight cradle shaped almost like a turnip. She covered the outside with gum like rubber, and it kept growing harder, so the babies dry. There were about sixty of us brothers and sisters when the eggs were all hatched. Our cradle-boat was fastened

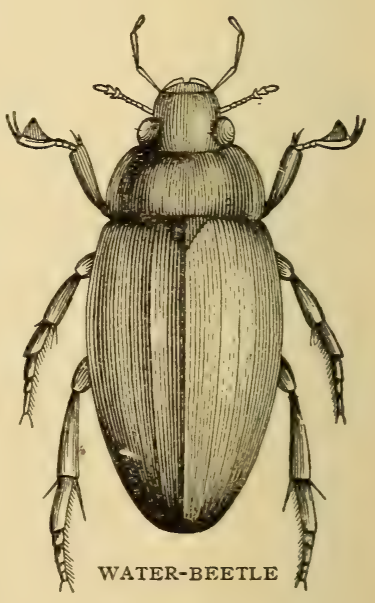
to a leaf. Here is a picture of it. There is a tube at the upper end. The picture shows how the eggs looked inside. Hazel: What is the tube for?

Beetle: To give the babies fresh air.

Glenn: How long did you stay in your cradle?

Beetle: It was about two weeks before we came out of the eggs. We all dropped to the bottom of the cradle, where we stayed several hours; but we were so hungry that we soon ate 
a hole through the silky wall, and then we dropped into the water.

Iva: What did you find to eat?

Beetle: Snails and other things; and we grew and grew. We soon outgrew our skins, and changed them three times. Here is my picture when full grown as larva. I was about three inches long, and always hungry. At

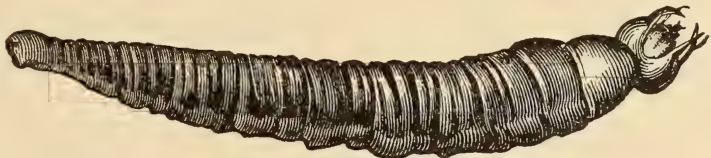

LARVA OF WATER-BEETLE

last I lost my appetite, crawled out of the water, and dug a hole in the soft bank, where I made a cell and turned to pupa. It took quite a long time to become a beetle,- - thirty-one days. Then I rested twelve days before I was ready to begin life as a full-grown beetle.

Hazel: Can you fly?

Beetle: Yes. I like best to fly at night. It is so pleasant to skim about in the moonlight"above the pond, and see how frightened the frogs are as we fall into the water with a splash.

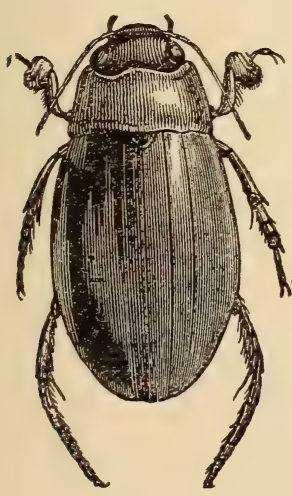

DYTiscus Cousin Dy-tis'cus, only half as large as I am, is a quarrelsome fellow. I keep as far from him as possible. He carries a spear, or fork, on the under side of his body. He always walks backward when trying to get away from one attempting to catch him, and as soon as he gets a chance, he will stick his spear into

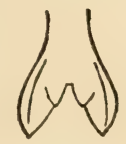

SPEAR OF DYTiscus one's hand, so he is glad to let go. His spear is shaped like this, and it makes a wound that smarts much. Like the rest of us, he can discharge a liquid which has such a bad smell that it serves to protect him from harm. He can not walk very well, but scrambles about. If he happens to fall on his back, he whirls round and round in a very funny way. This is his 
picture. See his curious forefeet. They look as if he were holding a ball in each one. His other legs are like oars, the same as mine. He will devour any kind of fresh meat. I never go near him, for although I am larger than he, if he gets a chance he pierces me at my weakest point, which is just back of my head, and would kill me if he could.

Glenn: Can he fly, too?

Beetle: As well as I can. When he wishes to take an air journey, he crawls up a stalk or reed, spreads his splendid wings, and away he goes. He may be found in almost any pond. If you watch closely, you may see him standing on his head in the water. This he does to get air. He does not carry a supply in a ball under his breast, as I do, but keeps it under his wing-cases. They are air-tight. When he wants a supply of fresh air, he comes to the top of the water, drives out the bad air he has used, and takes in a fresh supply while standing on his head with the upper part of his body out of the water.

\section{Some Odd Beetles}

Mother: There is a little beetle that marks a shield on the bark of aspen-trees, where it lays its eggs. The mother beetle rests on a branch with her head downward, and cuts a shield

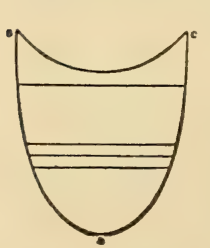

WORK OF ASPEN-

BEETLE like this picture.

These shields may be seen cut in bark at the South Kensington Museum. She does it with her jaws, cutting from $a$ to $b$, and from $b$ to $c$, then from $a$ to $c$, then she makes two or three straight lines across the middle. Cutting the bark and depositing the egg causes the stem to swell. In this swelling the larva lives for two years before turning to pupa. At the end of June the perfect beetle emerges from a swelling on the side opposite where the egg was laid. 


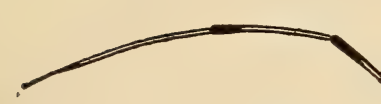

Harold: I read of on a branch above an her eggs down into it. eggs and carry them and afterward they tles as they do for Glenn: There are act as if dead when their legs under their signs of life, even when of these little mimics its body, which retains a little round, dusty legs be torn from its any sign of life. That

Mother: The muskIt emits a smell like when it is near without
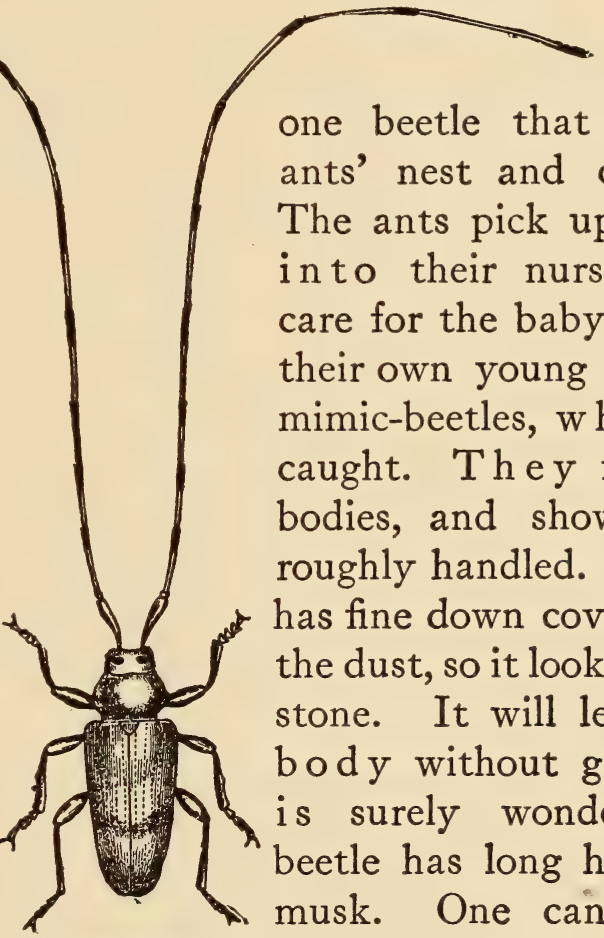

one beetle that goes ants' nest and drops The ants pick up the in to their nurseries, care for the baby beetheir own young ones. mimic-beetles, wh ich caught. They fold bodies, and show no roughly handled. One has fine down covering the dust, so it looks like stone. It will let its body without giving is surely wonderful. beetle has long horns. musk. One can tell the timberman seeing it, and it gives the odor of musk to anything that touches it. Musk-beetles are also called squeakers, because they make a squeaking noise by moving their heads quickly up and down. Here is a picture of another long-horned beetle.

Iva: Its horns must be three or four times as long as its body, What does it do with them when flying?

Mother: They trail behind. It is called the timberman. It is always ready for a fight with one of its brothers. Some little beetles have neither eyes, mouth, nor ears. They live in the nests of yellow ants, and are yellow themselves.

Hazel: Last night as I lay in bed I heard, "Tick, tick, tick, tick." I wondered what it could be, for there was no watch nor clock near by. 
Harold: That must have been the deathwatch, one of the tiniest of beetles, so small that it lives in a hole no bigger than a pin-head.

Mother: No doubt you have seen timber that was said to be worm-eaten, but it was beetles, not worms, that tunneled the little galleries. They live in wood as larvæ, pupæ, and perfect beetles. They bore and bore and bore, and the older and harder the wood, the better they seem to like it.

Glenn: I read that one of these little fellows was seen to come from a desk that had been used in an office in London for twenty years. When the wood was planed down, the holes where the larvæ had eaten through the solid oak wood were easily followed, and no one could tell how long the beetle had lived there.

Hazel: Here is a picture of one. If it stood on end and the legs were out of sight, it would look like a

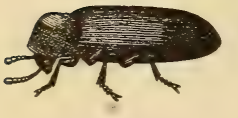
little old woman in a hood.

Mother: It can draw its head back under its Deathwatch hood. The picture is many times larger than the beetle itself.

Harold: I read about a beetle found by Mr. Paul Kibler near the Amazon River. He called it the dragon-beetle. It is about an inch long. Large numbers crawl on the sand near the river, and when touched, they squirt a liquid into the air which turns to vapor or smoke. A snapping, popping sound is heard, and at the same time something burns the finger, and it feels as if an electric wire had been touched. The liquid stops the breath, as does the smell of strong ammonia. The natives are afraid of this beetle, and say if the liquid gets into the eyes it causes blindness. Mr. Kibler caught about a thousand of them.

Mother: There are nearly five hundred kinds of beetles that live in ants' nests. Beetles are to be found everywhere, and 
are of all sizes, from immense goliaths to tiny creatures that can not be seen unless placed under a strong glass, and of which it would take one hundred placed in a row to make an inch. Yet these little dots have the most beautiful colors, and bodies that are wonderful to those who study them. Some sparkle like gems. All are busy, each in its own place and way. The family is so large that we can not hope to get acquainted with them all.

\section{THE TRUTH ABOUT BABY TUMBLEBUG}

Baby Tumblebug was tucked away in an egg, sound asleep. Father Tumblebug and Mother Tumblebug, his parents, were two black beetles who lived in the barnyard. Of course they talked tumblebug talk, and no one can be sure of what they said. It seemed like this:-

"Do you suppose the baby is warm enough?" asked Mother Tumblebug.

"Put some more blankets on him if you think he is not," said Father Tumblebug. "Here, I will help you. We must roll him up snug and warm."

Then they rolled Baby Tumblebug in so many blankets that he was entirely hidden among them; indeed, he was wrapped in a regular ball of blankets - a ball bigger than his father and mother put together. The blankets were nothing but dirt. The Tumblebug family have always used that kind. Thousands of years ago in Egypt, their ancestors set the fashion.

It was lucky for Baby Tumblebug that he was sound asleep, or he might have been frightened when his father and mother rolled him over the hills and valleys on his way to the nursery.

"It seems to me," said Mother Tumblebug, "that under that tall grass by the fence is just the place that will suit us."

They were looking for a suitable nursery for Baby Tumblebug. He was too young to be left on top of the ground, ex- 
posed to the hot sun and possible enemies. All tumblebugs spend their baby days in underground nurseries.

"Just as you think best," replied Father Tumblebug, standing on his head, and getting into position to push the ball, while Mother Tumblebug climbed on top of it.

"Now I am ready, Father Tumblebug," she said, leaning all her weight toward the front of the ball. Father Tumblebug, walking on his hands, kicked with his hind feet. Mother Tumblebug pulled, and over went the ball. This was done again and again. As often as the ball went over, Mother Tumblebug climbed to the top, ready for another start. Not for an instant did she leave Baby Tumblebug. Even when Father Tumblebug gave a mighty kick at the top of the hill, she kept tight hold of the precious bundle, rolling over and over with it until the ball stopped.

"Are you hurt?" he asked, running to her assistance.

"No, thank you," she answered; "I bumped my head a little, that is all."

Mother Tumblebug's head was flat, $\mathrm{O}$, ever so flat!

"I was afraid the baby would get uncovered, but he is safe, the little darling. You must be more careful, Father Tumblebug. I told you we should have gone the other way. I almost knew we were on a hill."

Father Tumblebug did not say a word, but he looked as cross as a bear. It was not so easy as it seemed to help roll that ball by standing on his head and kicking with his hind legs. She ought to have told him of the danger

At last a place was found to put the baby. It exactly suited Mother Tumblebug, so she and Father Tumblebug shoveled away the earth beneath the ball.

"Now run away, Father Tumblebug, run away. I can get the baby into the nursery without any more help, thank you."

Father Tumblebug was very glad to be excused. Mother 
Tumblebug was a great worker. She was not a bit afraid of spoiling her hands or her clothes. Upside down she went beneath that precious bundle of hers, digging with her hands and feet into the earth, and tossing it above the ball. Slowly Baby Tumblebug, cradle and all, went into his down-cellar nursery. Mother Tumblebug had a middle pair of legs, with which she clung to Baby Tumblebug's bundle of blankets, at the same time pulling it downward. In a little while she was out of sight, and how she ever managed to dig deeper into the darkness of the ground is something known only to tumblebugs. When her work was done, Mother Tumblebug climbed through the loosened earth into the daylight. That was the last she ever knew of Baby Tumblebug.

When he awoke, he crept out of his egg, and ate everything he found among the blankets. He outgrew his baby clothes in no time, and finally when he was big enough to wear the same kind of suit that his father and mother wore, he left the nursery, poking his queer, flat head out of the earth - a baby tumblebug no longer.-Sunday School Times. 


\section{LEPIDOPTERA \\ Butterfly or Moth}

Hazel: You are very pretty, Mrs. Butterfly. It seems as if your wings were covered with rainbow dust, they are so bright and have so many different colors. Do you have just two wings?

Butterfly: No, there are four - two forward and two hinder ones. I have no claws nor sting, and I carry no gun nor spear, so can only protect myself by flying away from my enemies. Birds and dragon-flies would soon eat me if they had a chance.

Harold: To what family do you belong?

Butterfly: To the Lep-i-dop'te-ra. Our family is divided into two general classes, - butterflies and moths. Butterflies fly in the daytime; moths fly in the evening and at night. When the butterfly rests, its wings are raised straight up over its back, or keep moving up and down; when a moth lights, its wings remain flat and sloping like the roof of a house. A butterfly's horns, or antennæ, usually stand out straight and have little kncbs at the ends; those of the moth curve, and hardly ever have knobs. The wings of most butterflies are much alike on both sides, while moths have their brightest colors on the upper side. The larvæ of butterflies spin only a little; those of moths spin a great deal. Moths destroy much more that is useful than do butterflies.

Glenn: Where do butterflies live?

Butterfly: In all parts of the world where flowers grow. They are found even in Greenland. In hot countries we grow larger and wear more brilliant colors than in colder climes. The tropical butterflies are very large, and their colors are so bright that you might fancy they were flying rainbows. 
Iva: Mrs. Butterfly, will you please tell us what you eat? Butterfly: Honey, always honey, though there are a very few butterflies who have the bad taste to eat the juices of dead animals. No butterfly hunts and kills other insects. We suck honey from the beautiful flowers, and delight in their colors, which are so much like our own. We are children of the sunshine and the flowers, and our lives are spent without an anxious thought or care. As we quiver on the edge of some dainty flower, sipping honey, folding and unfolding our gorgeous wings, do we not make a beautiful picture?

Harold: I am sure that of you it might truly be said that "Solomon in all his glory was not arrayed like one of these."

Butterfly: And we take pleasure flitting here and there as we dart through the air, playing

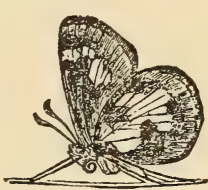

BUTTERFLY AT REST with our companions, rising higher and higher till we disappear over the tree tops.

"From flower to flower on balmy gales to fly, Is all we have to do beneath the radiant sky."

My brilliant colors are on the inside or upper side of my wings. Some have them that way for protection. Now I shall light on this gray wall a moment.

Hazel: Where has our butterfly gone? I didn't see it fly away, did you?

Butterfly: I was here all the time. I simply folded my wings, and the colors on the under side are so like the wall on which I am standing that you could hardly see me. That is one way I have of protecting myself from birds who would put an end to my life if they could. My eyes are large, so I can watch for them. We have compound eyes. Some butterflies have sixteen thousand facets in one eye.

Harold: That would make thirty-two thousand eyes for one butterfly! 
Butterfy: I have a long tube, or proboscis, with which I suck honey from flowers. It looks like a black thread. Here is a picture of it. I can curl it up out of the way. It is a long

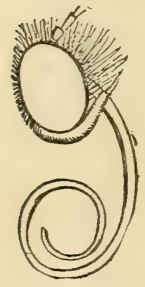

PROBOSCIS OF pump made of two half-tubes, as if a tube were split in two lengthwise. I can open this tube, hook the two sides together, and then stick it deep into a flower and pump out every drop of honey there.

Harold: Did you come from an egg? and were you larva and pupa before you became a perfect butterfly?

changes. Some butterflies' eggs are more beautiful than you can imagine. They may be seen in every shape and color, white, orange, red, blue, and green. Some are round, others long; some are pear-shaped, and some look like the tiniest loaf of bread. The outside of some is carved in exquisite patterns. Others are perfectly smooth, but glow like pearls. Some have raised lines all over them, or little warts. The strangest of all is the egg that has a little door at the top, which the larva lifts when ready to come out. Some are fastened with a tiny spring which the insect touches at the right moment and in the right way.

Glenn: Please tell us if butterflies' eggs are like birds' eggs inside?

Butterfy: No, nor outside either. Birds' eggs break because the shells are so brittle; but butterflies' eggs are hard and horny, so they are not broken easily, and inside they are filled with greenish fluid, and have no yolk.

Harold: Where do butterflies lay their eggs?

Butterfly: On any plant that provides the right food for their children. Some choose one kind, some another, but they never place their eggs on the wrong leaves. You can learn about butterflies by getting the eggs and watching 
them through the different changes until they become butterflies. There is no other insect that you can study so well.

Iva: Will the larvæ of butterflies eat all kinds of leaves?

Butterfly: That depends on the kind of larvæ. Some will eat anything, from a rose-leaf to a thistle. One kind has been known to feed freely on twenty-seven different plants. Others will starve to death before they will eat more than one kind.

Glenn: Are the larvæ worms?

Butterfly: They are caterpillars.

Iva: But caterpillars are worms, aren't they?

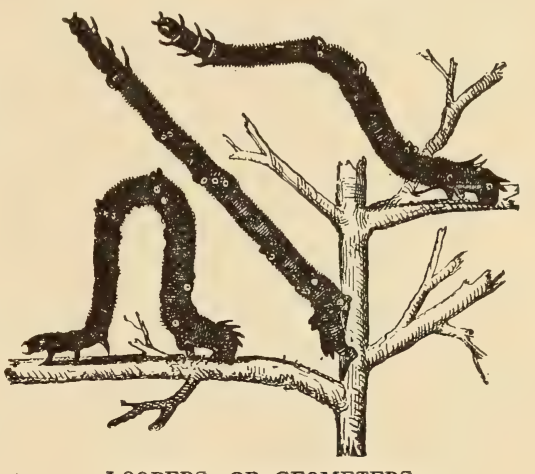

LOOPERS, OR GEOMETERS

Butterfly: No, indeed; a worm is never anything but a worm, but all caterpillars become either butterflies or moths.

Hazel: How do caterpillars become butterflies? Butterfly: Caterpillars are long and round. Their bodies are made up of a number of segments, or rings. They have hard, horny jaws, which move like scissors. Near the head is a spinneret, for caterpillars can spin silk as well as spiders can. You have learned that they eat leaves, and they lose no time in beginning, for that is their earliest occupation, and they are very hungry. Sometimes their first meal is the empty egg-shell from which they were hatched. Then they begin to eat the leaves of their food plant. They have six true legs, which end in hooks, and they also have from two to ten false legs, or claspers, by which they hang fast to LOOPER HANGleaves and stalks when eating. Those having the ING BY ITS THREAD most legs walk with a smooth, waving motion, and 
take short, quick steps. Some have legs only at each end of the body, and are called loopers, or geometers. You have seen these caterpillars stretch out and then curve the body into an arch, as shown in the picture.

Glenn: They can take long steps that way.

Butterfly: Some loopers are the color of the bark on which they rest. With their hind legs they take hold of a branch, and then stand out straight, looking like a twig. In this way they stand for hours without moving; thus they "play possum" all day, and feed at night. Some of these strange caterpillars have heads like buds, and little lumps on their bodies like notches in twigs. They spin as long or short a thread as they please, and, though it looks so weak, it is strong enough to hold them in the air. The caterpillar can stop or go on as it chooses; it can descend from the topmost twig of the highest tree to the ground; then it can climb up again, rolling up its thread as it mounts. When it goes as high as it cares to, it cuts the thread and throws away the tangled ball, for it can make a new one at any time it pleases. Each kind of insect, in eating, leaves its
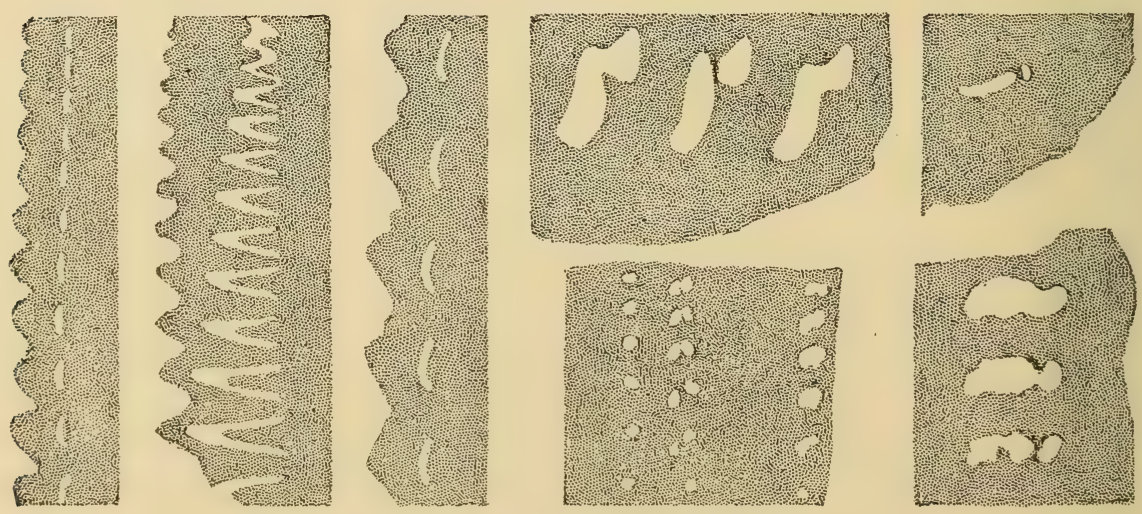

FRAGMENTS OF LEAVES EATEN BY CATERPILLARS

own mark. Here are pictures of some of the patterns they make on the leaves. 
Iva: They look like embroidery. What wonderful workers! Butterfly: One butterfly always writes her name by making a hole in the leaf in the form of a cross, and she eats away

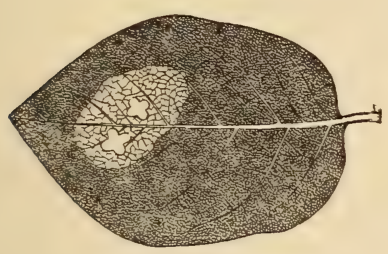

CROSS MADE BY A BUTTERFLY a part of the soft, green surface of the leaf around the cross.

Hazel: Do caterpillars live alone?

Butterfly: Some do, the same as bees and wasps, while others stay in companies.

Glenn: Aunt Jennie said that in the South Kensington Museum there is a round nest as large as a foot-ball filled as full as possible with large caterpillars.

Harold: Do all caterpillars eat leaves?

Butterfly: A few feed on flowers and fruit. Most of them grow very fast, and eat greedily. Some eat their own weight in leaves every day.

Iva: Do they eat the edges of the leaves first?

Butterfly: Yes; they pass the edge of the leaf between their legs, and stretch out the head as far as possible. Each bit of leaf is swallowed as soon as cut.

Harold: Do caterpillars change their dress as they grow?

Butterfly: O, yes, many times. The skin on their bodies and their legs, and the horny covering of the head and jaws, and the inside lining of the mouth are all changed. Two or three days before the change, the caterpillar stops eating and keeps very quiet. Its colors fade, and its skin dries up and splits open on the back. The opening keeps growing larger till it is big enough for the head to be drawn out, and then the rest is easy. It takes only a minute to slip off the old suit.

Iva: Does the new skin look like the old one?

Butterfly: The same, only it is bright and clean and large. The caterpillar is very tired after the change, and rests several 
hours. But then it has more room for food than before. Some eat up their old skins; others move to new feeding-grounds, but all begin to eat more greedily than ever.

Harold: Why do caterpillars eat so much?

Butterfly: Because they must grow. All insects attain their full size while larvæ. While in the pupa state, they eat nothing, so they store up fat for that time.

Hazel: Many caterpillars wear such bright colors I should think they would be eaten by birds.

Butterfly: I suppose many are, and yet they have ways to defend themselves. Some wear thick coats of fur and roll themselves into balls, which make hairy mouthfuls that no bird would care to swallow. Some are covered with hairs that sting and burn, making them very unpleasant to handle. Do not touch them with bare hands, for the hairs come out and stick in the flesh like briers, and sting like nettles.

Glenn: Can any caterpillars shoot like some beetles?

Butterfly: Yes, only they shoot people instead of insects.

Harold: A man went to look at

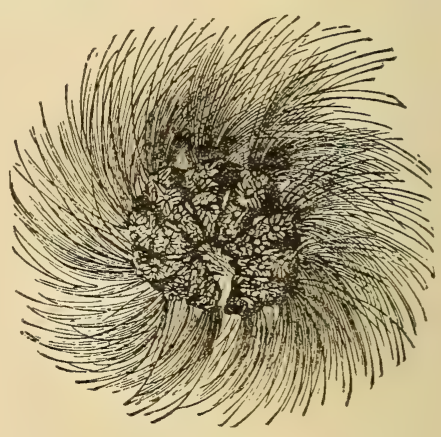

A HAIRY MOUTHFUL some caterpillars he had put into a dish and covered with glass. As he removed the glass, one of them squirted liquid into his eye. He rushed to the doctor, but for several days could not see at all with that eye. Another man was hit on the nose, and the liquid was so poisonous it took the skin off.

Hazel: Do caterpillars eat at night?

Butterfy: Many do; some are so hungry that they eat both night and day. They have many deadly enemies. The ichneumon-fly is one of the worst. It lays its eggs in their bodies, and the larvæ live inside as free boarders. Some caterpillars 
lift their heads and look very fierce to frighten Mrs. Ichneumon away, as a hen ruffles her feathers when she thinks her chickens are in danger. It is a serious matter with the caterpillar. One caterpillar has two horns on its tail, out of which it sticks two long red streamers, which it waves about like danger-signals. Another has very long front legs, with which it warns away unwelcome visitors. Others look like spotted snakes, and the birds are afraid of them. One caterpillar in India can even hiss like a snake.

Hazel: Once when I touched a caterpillar it rolled itself up into a ball and dropped to the ground. I tried to find it again, but could not.

Butterfly: That was its way of protecting itself. There are quite a number that adopt that plan when touched or if the branch on which they are feeding is shaken. Those that feed on leaves are green, and their color protects them.

Harold: I suppose the pretty butterflies we see in the air spent their early life hidden in some quiet place, eating and growing, resting and waiting, until at last wings were given them, and they entered on a higher life. Perhaps it will be that way with some of our lives. It may seem as if they are hidden and lost, but some day we, too, may have wings; we may be bright as the sun, and shine like the stars.

\section{THE CHRYSALIS}

Hazel: Did you crawl into the ground to pass through the pupa state?

Butterfly: No. When I felt that my days as a caterpillar were ending, I stopped eating, and found a snug corner in the fence, where I began to spin, and covered quite a large place with a mound of silk. I wanted something to which I could hang myself. After I had spun enough silk, I hung my body up by the hooks in the legs nearest my tail. For about 
twenty-four hours I kept squirming and twisting about until the skin burst open on my back, and I came out in a new, fresh skin, not at all like my old one. I had a new body, too. I was no longer - a caterpillar, but a creature without head, legs, or wings. I kept hold of the old skin I had just pushed off. My new body was made of rings that overlapped one another like a telescope, so I caught hold between two of the rings, and climbed to the top of my old skin, fastening myself to the silk by a little hook. My next work was to push the old skin off. I gave a big jerk, and whirled round and round. That did not

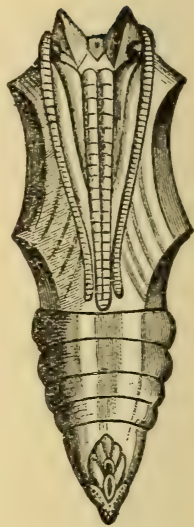

CHRYSALIS OF THE LARGE TORTOISE-SHELL loosen it, so I twirled around the other way Burterfly awhile till away it went, and I was free. Then I took a

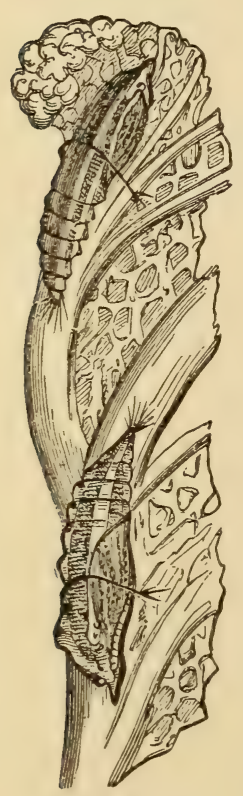

PUPAE FASTENED BY BELTS nap lasting two weeks.

Harold: Do all caterpillars hang themselves as you did?

Butterfly: No; some fasten themselves to a leaf or twig, or hide away in any cozy corner they can find. Some spin a belt to hold themselves to the place where they turn to pupx. The caterpillar spins a thread of silk, and fastens it on one side of its body, then passes it over and fastens it to the other side, so making a strong band which holds it in place when it can no longer move. Here is a picture of chrysalises as they look with belts around them. Some caterpillars fold two or three leaves into a little house, and there pass their pupa days. Some make a cocoon of earth, and line it with a kind of paste that comes from their bodies. Some bury themselves in the ground, and the 
chrysalises look smooth and shiny, as if varnished. Some pull out their hair and mix it with silk to make their cocoons. Others cut off their hair. If the cases in which they wrap themselves are opened, the caterpillars are found naked.

Hazel: Do some make cocoons of silk?

Butterfy: Caterpillar moths do. They spin more than we can. When butterflies or moths can not get what they want to make a cocoon, they use what they can get, as paper or cloth.

Harold: How long do they stay in the chrysalis state?

Butterfly: Some remain in it all winter, and they have been seen with icicles hanging from them. The cold does not kill them. They have been shut in ice-boxes during the summer, and so kept for a year. They do not seem to mind the cold; they may be frozen stiff so they will snap like glass, and yet become butterflies. Chrysalises have been put in a warm place in midwinter, and the butterflies soon came out.

Harold: A gentleman once found a double chrysalis. It seemed that two caterpillars had agreed to build a cocoon together; but when the inside was examined, it was seen there had been a falling out, and neither developed into a butterfly.

Glenn: Is it as hard for the butterfly to get out of the chrysalis as for the caterpillar to change its skin?

Butterfly: About the same. When I was ready, the dried skin in which I had been sleeping began to crack open on top of my head and thorax. I kept moving and wriggling about, and soon there was a place big enough for me to stick my head out. I was tired and weak; but after a little I succeeded in drawing my body and wings and legs out of the tight place where they had grown. My wings were folded up so tightly and in such small space that I had to wait until they unfolded and dried. At first they were thick and flat, but while I waited in the sunshine, they spread out and became firm and hard. My whole body became fit for the new life I now lead. 


\section{Earth to Air}

A little worm on a branch of gray Began his work one summer day. He planned and built, he wove and spun, Until his tiny house was done.

He laid the walls with leaf-green rails; He set the roof with golden nails; He wove a sheet of softest lace, And in its folds himself found place.

He slept, and in the dark of night, Upon his sides grew wings of light. The shining house became a veil, And gone was every golden nail.

Through the thin walls of gauze I spied The rainbow wings he had not tried. They cradled close and folded tight His velvet body, strong and light.

On sped the hours till sleep was done; $W$ ide swung the doors to life's new sun. He woke. He longed his wings to try, And found himself a butterfly.

-Lydia A. Coonley. 


\section{WHAT BENNIE SAW}

Bennie was out in the orchard sitting under a tree. Ten minutes after mama had first looked, he was still there. Fifteen minutes later mama looked again, and there he sat in the same position.

This was growing serious. Something must be the matter to keep Bennie sitting still a whole half-hour. Perhaps he was sick. Maybe he had hurt himself. But then he would cry. Could he be asleep sitting up straight like that? Mama went out to the orchard, and came up softly behind the little fellow. He was looking steadily at a small bush in front of him. Upon it was a large, handsome butterfly drying its wings upon its empty shell. The butterfly stayed an instant longer on the bush, and then, lifting its beautiful wings, it flew away, and was soon out of sight.

The charm was broken, and Bennie sprang to his feet. On seeing his mother, he exclaimed, "O mama, did you see it, too?"

"I saw a butterfly fly away from the bush," answered mama. "What did you see, Bennie?"

"Why, mama, I saw two bugs come out of bags, and turn into butterflies."

"Did you, my dear? That is wonderful! Tell me all about it, little man."

"Well, I sat down here because I was hot running. I saw those bags stirring. I was going to pull them off, but those bags just opened their own selves, and two funny bugs crawled out. Those bugs crawled on top of the bags, and sat still. Pretty soon they swelled up, and I saw some wings grow on those bugs. They kept swelling and swelling, and the wings kept growing bigger, and I didn't dare stir. First one butterfly flew off, and then the other. I saw all this, mama; I did not make believe one single bit." 
"I know you did not, Bennie; but the wings were there all the time; they were folded up tightly like the leaves of a rosebud, and you saw them unfold," said mama. "Don't forget it, dear; for you have seen a wonderful sight." - Selected.

\section{SPRING}

Listen! What a sudden rustle Fills the air!

All the birds are in a bustle

Everywhere.

Such a ceaseless croon and twitter

Overhead!

Such a flash of wings that glitter

Wide outspread!

Far away I hear a drumming,

Tap, tap, tap!

Can the woodpecker be coming

After sap?

Butterflies are hovering over,

Swarms on swarms,

Yonder meadow patch of clover

Like snow-storms.

- Selected.

\section{Wings and Scales}

Hazel: One time I caught a butterfly in my hands, and when I let it go, there was colored dust or powder all over my hands.

Butterfly: That was some of the scales that came from its wings. Butterfly scales are so small that they can be seen only when placed under a strong magnifying-glass. One man said the scales on our wings are as iovely as diamonds. On the opposite page are pictures of some of the different kinds of butterfly scales. 
Glenn: Some look like little pitchforks; some are shaped like a fan, and some like flower-buds. How pretty they must appear under a glass that would show them as having every shade of color we can think of.

Butterfly: The closer you examine their shape and colors and arrangement, the more you wonder and are delighted.

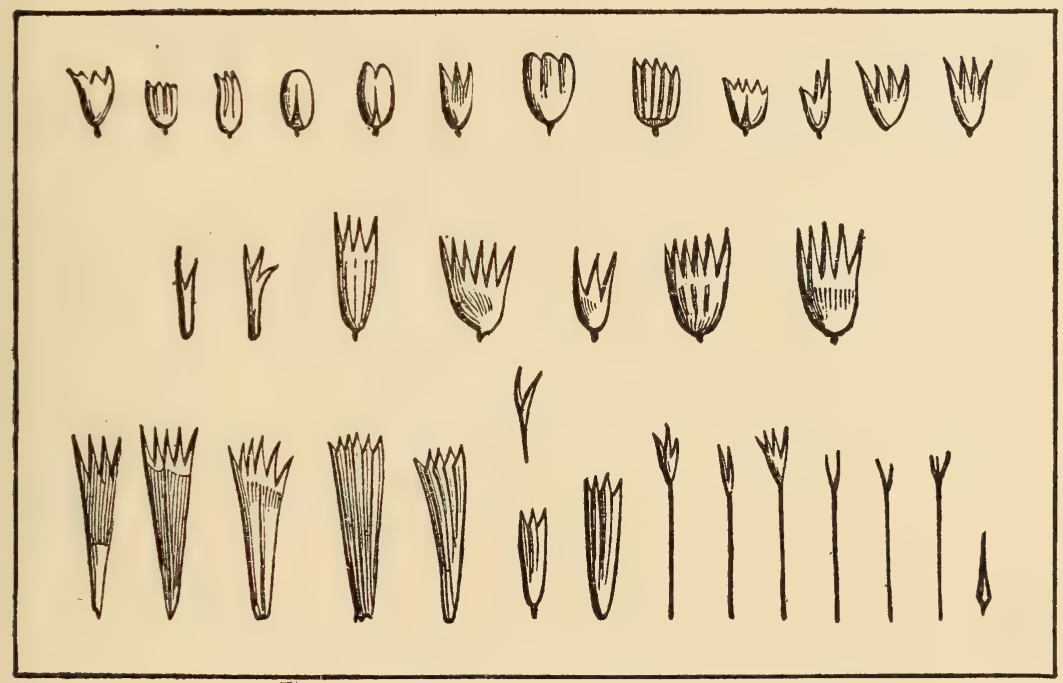

DIFFERENT FORMS OF THE SCALES OF BUTTERFLIES

Glenn: Do the scales overlap one another like those of fishes?

Butterfly: I think so. The best way to learn about them is to study the butterflies themselves. We are of many sizes, from half an inch across our wings to those in tropical countries whose wings spread a foot wide.

Harold: Can you fly a long way?

Butterfly: 'Yes, but we do not fly in a straight line. We go up and down and zigzag about; so a bird trying to catch a butterfly breakfast finds it not easy to do.

Hazel: Do you live a long time? 
Butterfly: No, our lives are short. People sometimes think we are idle creatures, but Mrs. Butterfly has other things to do than to show off her fine clothes. She must find a home and provide food for her children; and after laying her eggs she soon dies. Some lay no more than a hundred eggs, while some lay thousands. I suppose in a way our beauty is a protection, for many persons who despise and destroy our caterpillar children, admire us as we flit about, and never think of blaming us for the thousands of caterpillars that eat their trees and plants. But moth caterpillars are most to blame for the mischief done.

Harold: Do butterflies do any good?

Butterfly: We make the world brighter and the people happier, but I never heard that we furnish food for any people except some savages in Australia. Small butterflies are found there in great numbers. When they light on the rocks, fires are built under them, and they are smothered. Bushels of the dead bodies are gathered, and after the wings are removed, they are baked into cakes. Cabbage-butterflies are found in all

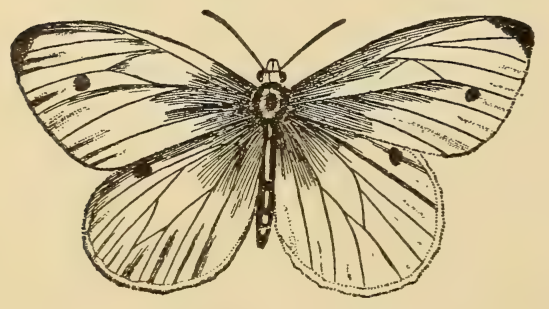

CABBAGE-BUTTERFLY countries from early spring till late autumn. They wear white dresses with veins and spots of black. The larvæ live in groups on cabbage leaves, turnips, and mustard, and are so greedy that they will eat more than their weight of leaves every day. The caterpillars are greenish-yellow with long yellow stripes and black dots. You may find them among your cabbages. The small butterflies are called small whites, and the large ones are called large whites. There are sixty-four kinds of white butterflies.

Hazel: What is the name of the butterfly that we see so often, of a brownish-yellow color with black stripes, and on 


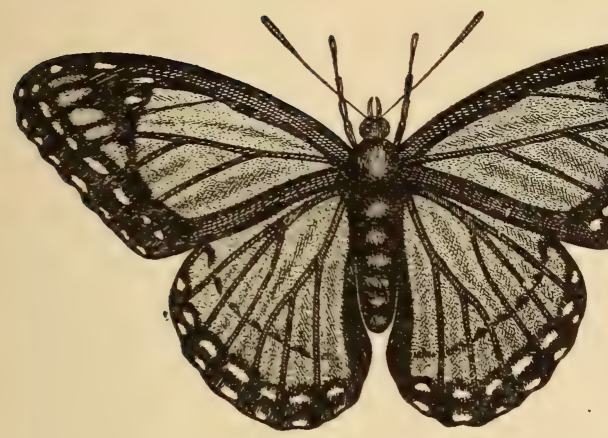

THE MISIPPUS BUTTERFLY

its wings a black border spotted with white?

Butterfly: That is the misippus. Its caterpillars eat the leaves of poplar-trees. This butterfly, with wings like sails, is found in the White Mountains of New Hampshire, and is called the mountain butterfly. Should you visit Mt. Washington in summer, you would find it there. There are four kinds of mountain butterflies in the United States. You have often seen little Philodoce, the yellow

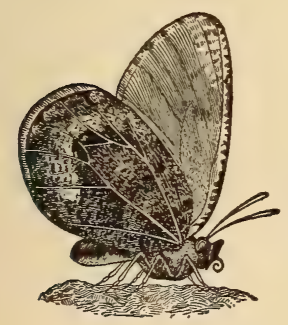

THE MOUNTAIN BUTTERFLY butterfly. The name means lovers of the wayside. After a summer shower you may see dozens of them standing around a pool of water. They lift their yellow wings like dainty ladies, and stand and sip and flutter, making the damp ground look as if a shower of golden buttercups had fallen. Here is a picture of $\mathrm{Pa}$-pil'io.

Iva: It has tails on its wings.

Butterfly: And for that reason it is sometimes called the swallowtail. Some butterflies have tails an inch long. One is called asterias, which means starry. It has tiny yellow spots on its black, velvety wings, which look some like stars shining out of a dark sky. A picture of the asterias, one of its caterpillar, and one of its chrysalis, which has tied it-

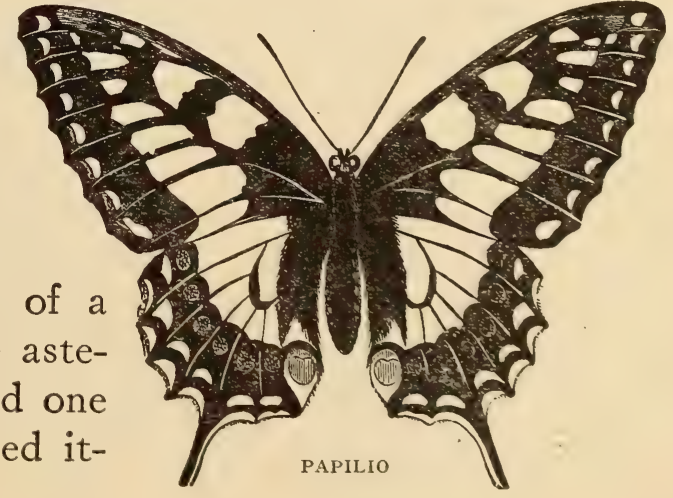




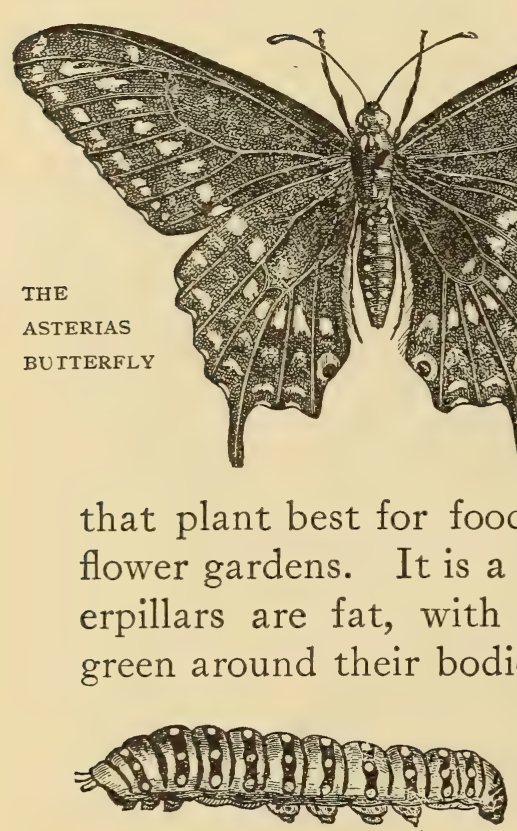

THE CATERPILLAR, OR LARVA, OF

THE ASTERIAS BUTTERFLY

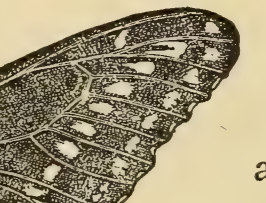

\section{Butter}

self to a twig, are shown on this page.

Glenn: Then we have a picture history of the three lives it lives.

Butterfly: Another butterfly, which is found on milkweed, is c a lled the monarch, or milkweedbutterfly; for it likes It may often be seen in flower gardens. It is a beautiful creature. Its caterpillars are fat, with rings of black, yellow, and green around their bodies. Near the head and also

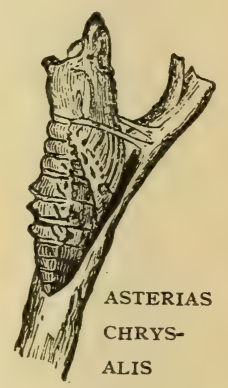
near the end of the body are pairs of threadlike horns, which, when disturbed, these caterpillars wave like whips. The chrysalis is one of the prettiest you ever saw. It is green, sprinkled with dots of gold.

Harold: Are the butterflies green and yellow?

Butterfly: No, they are red. They are so large that they are rightly named monarchs. The male carries a little perfume pocket on each of his hind wings a $\mathrm{nd}$ no dandy ever wore a finer dress. They are great travelers, and fly north in summer and south in winter.

Glenn: I did not know that butterflies travel like birds.

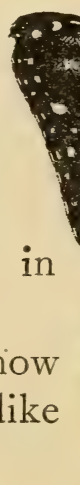

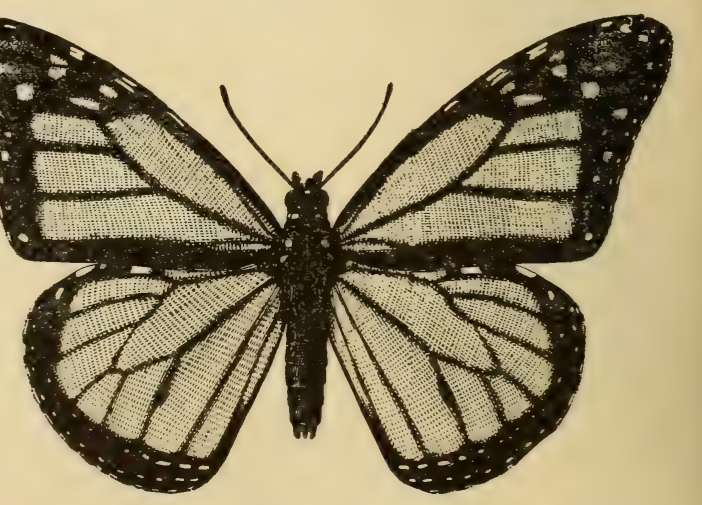

MONARCH BUTTERFLY 
Butterfly: Most of them do not, but the monarchs do. They have even been found flying over the sea five hundred miles from land. As the weather becomes cold, they go in large numbers to warmer climes. In spring the mother monarch flies northward as far as she finds milkweed pasture, and then her children push onward still farther, so they are found in all countries and in the islands of the sea. Now you will

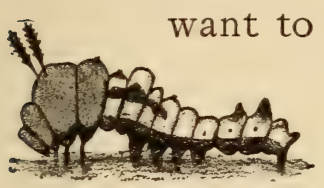

VICEROX CATERPILLAR hear about the viceroy, which is quite like the monarch, only smaller. It is an orangered. The monarch has two rows of spots on its wings, while the viceroy has but one. Its likeness to the monarch protects it from birds, which delight in butterfly dinners and teas, but the monarch is distasteful to them, while the viceroy would be relished.

Hazel: How does a viceroy's egg look under a microscope?

Butterfly: It is dark green, and is placed at the end of a poplar or willow leaf, the last one on the branch. Though the egg is so small, it is carved in lovely patterns.

Glenn: How many eggs are placed on a leaf?

Butterfly: Only one. In a few days the brownish larva crawls out of its egg, and the first thing it does is to eat its eggshell. Some prowling spider or hungry insect might see it, and find the larva; so the larva eats the egg-shell to protect itself, then goes to the end of its leaf and eats the soft part, leaving the hard midrib in the center. On this it perches in the daytime, and feeds mostly at night. This larva makes up a little bundle of worthless stuff, and fastens it with a silken thread to the midrib between its feeding-ground and restingplace. So if some insect should find that bundle, it would be discouraged about going any farther. It has another clever trick, it eats up its old skin as soon as it crawls out of it. The viceroy grows more ugly every time it molts. If disturbed, it 
swings its head from side to side, and in all possible ways shows its rage.

Harold: How does it look when it turns to a chrysalis?

Butterfly: You would laugh if you saw one. It has a bunch in front that looks like the biggest Roman nose. No bird would try to swallow such a humpty-dumpty morsel, for fear of having its throat scratched as it went down. In about a month from the time the egg is laid, the perfect butterfly is ready for flight. It lives in North America, and if it becomes larva in midsummer, when about a third grown it chooses a

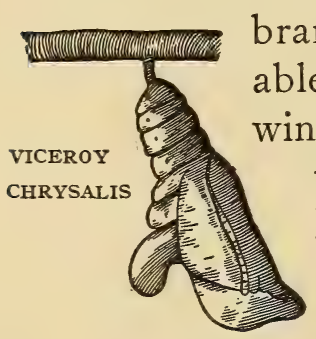
able leaf, and fastens the leaf to the branch by winding it about with silk, to keep it from falling to the ground, as other leaves do in autumn. It first eats the end of the leaf squarely off, then folds up the part that is left into a round roll, and sews a seam with silken thread. When this leafy tube is done, it lines it with soft, silky blankets of its own weaving, and then crawls inside for a long nap during winter. Its warty tail fills up the end and makes the door.

Harold: How does it know winter is coming?

Butterfly: I do not know; for it begins its work before there is a sign of frost or snow, and its mother did not build such a house. It chooses a leaf that will be covered up by the snow, and where it will be best protected from the cold. When the new leaves appear in spring, it backs out of its winter house and begins to eat. Another family of butterflies is called Va-nes'sa. They live on elm, willow, oak, and many fruittrees. One is called Vanessa antiopa, and another Vanessa polychloros, or the tortoise-shell butterfly, because the rich brown dress it wears has the colors of the tortoise-shell. Its chrysalis is beautiful, and the baby butterfly looks as if wrapped 
in a case of gold. As it leaves the pupa-case, a little red liquid like blood drops from it. If a great many butterflies are hatched at the same time and place, there are a good many drops; so ignorant people, when they saw them, thought there had been a shower of blood, and that some great calamity was coming upon the country.

Harold: Had they known more about butterflies, they would have been saved this fright.

Butterfly: One of the Vanessa family is called the red admiral, because it has bright red bands on its black wings. There is another called the white admiral. Vanessa antiopa has a broad white edging on her wings, so is sometimes called the whiteborder, or the Camberwell beauty. The Vanessa family is very common in Europe and America. A man once saw the Vanessa polychloros leave some eggs on a leaf, and he cut off the branch and put it away. Mrs. Vanessa wanted to put some more eggs with the others, so she kept flying about, up and down, hunting for the branch she had lost. She has a rule regarding the number of eggs to put in one place, and she could not be happy if obliged to put them in any other. The man saw how worried she was, so he tied the branch where it was before. Vanessa soon found it, knew it was the one, and put enough eggs on the leaf to make the right number.

Harold: William Kirby spent several months on the Amazon River collecting different kinds of insects. Lord Rothschild paid ten thousand dollars for the only butterfly that could be found of one family. A pretty black, purple, and blue butterfly found in South America, called the agrya, sells in Germany for fifty dollars. A pair was sold in San Francisco for one hundred forty dollars. But it is not easy to stay to catch them in a country that is full of snakes, and where mosquitoes are so thick they cover one's body and bite through the heaviest clothing, and where tarantulas are big enough to 
cover a saucer. Mr. Kirby caught about five hundred with forceps so they could not bite him. He sold them for from twenty-five cents to one dollar each.

Glenn: I should think anybody would be afraid there.

Harold: Mr. Kirby was trying to find the Hecuba butterfly. It is very hard to capture, as it flies twenty or thirty feet above the ground, and will not come nearer. They are sold for ten dollars each. Mr. Kirby tried to get them by putting bright-colored things in the path; he hung bananas in the trees; he tied a butterfly to a shrub, and, though its flutterings brought plenty of bright-blue butterflies, so he caught about five hundred, yet the Hecuba sailed on above his head. Then he tried strong-smelling baits; then he sang to them half an hour at a time, but they flew no lower than before. At last he set a mirror in the path where it would reflect the sun. A big Hecuba came along, saw the glittering thing, and flew straight down. It did not seem to see the man at all, and in an instant was in the net. Mr. Kirby had no trouble then in getting as many as he cared to obtain. While he had been waiting and working three months for that prize, he found many strange creatures. One was a snake that made a sound like a crying baby. Another was a wasp that could sing like a jew's-harp. But best of all was a little bird that called out in a clear voice, "Bentivi," which in the Portuguese language means, "I see you," or "Peek-a-boo." There are tiny butterflies called coppers and blues, because they are of those colors. Another is called the purple emperor. One pretty butterfly is called the painted lady.

Hazel: Aunt Jennie has seen in different museums some that were the brightest blue, and much larger than any we ever saw. Others looked as if covered with black velvet, with green and gold for trimming. One from South America was eight inches across its wings. It was golden brown, mixed with other 
shades, and was very beautiful. The wings of the dead-leaf butterfly look like withered leaves.

Iva: I didn't know there were so many kinds of butterflies.

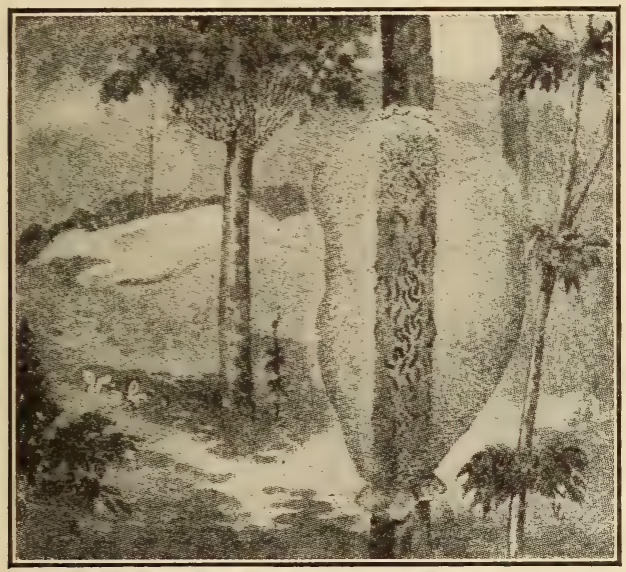

GAUZE INTS AROUND TREES ON BUTTERFLY FARM TO KEEP THE CATERPILLARS FROM ESCAPING

Harold: I suppose we have learned about only a very few of them. There is a farm in England devoted to raising butterflies. Three acres of land covered with bushes and a few big trees, are used for this purpose. The trees and shrubs are enveloped in huge bags of gauze to protect the caterpillars and butterflies from the birds. At this place all kinds of British moths and butterflies are reared, and the owner sells about thirty thousand insects a year, at prices ranging from a few cents to fifty dollars.

\section{WHAT DOES IT MEAN?}

UP and down the midges dancing On the grass,

How their gauzy wings are glancing As they pass!

What does all this haste and hurry Mean, I pray,-

All this outdoor flush and flurry

Seen to-day,

This presaging stir and humming, Thrill and call?

Mean?- It means that spring is coming; That is all. 


\section{Moths}

Hazel: $\mathrm{O}$ mother, please tell us whether this is a moth or a miller!

Mother: It may be both. A miller is a pale, whitish moth. I suppose they are called by that name because they have a dusty look, like a man in a mill who is covered with flour.

Hazel: It looks some like a butterfly.

Harold: Do moths like sunshine, mother?

Mother: Their habit is to fly early in the evening or at night, and to rest in some quiet, shady corner during the day.

Glenn: Is the moth family a large one?

Mother: Yes, much larger than that of its cousins, the butterflies. They exceed in size the largest butterfly, and some

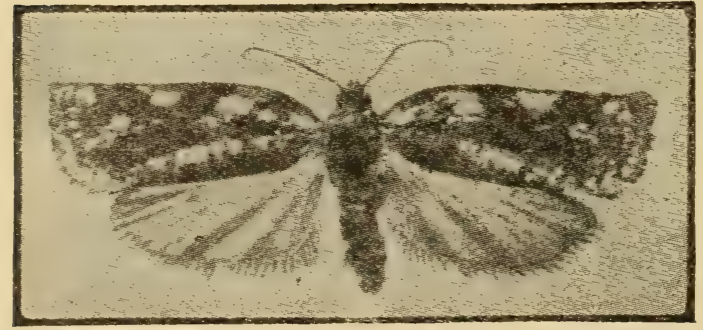

MOTH of them are smaller than any butterfly known. They have four wings like the butterfly, but they hook together on each side. The moth has a la rger waist, th a t makes it look as if it wore a cloak. This you can see by looking at the picture. Iva: Moths are not so pretty as butterflies.

Mother: They do not wear as gay colors, but some are dressed in the loveliest and most delicate shades you can imagine. They lay more eggs than the butterfly, and are great spinners. Some of their spinning is very useful to you.

Hazel: Such moths as ate your fur cape and my woolen dress do much harm.

Harold: The gipsy-moth and the brown-tail moth destroy our shade-trees. In the eastern part of Massachusetts seven 
hundred fifty thousand dollars has been paid to destroy their eggs and nests, and it is thought that it will cost many thousands of dollars more. Here are their pictures. The male and

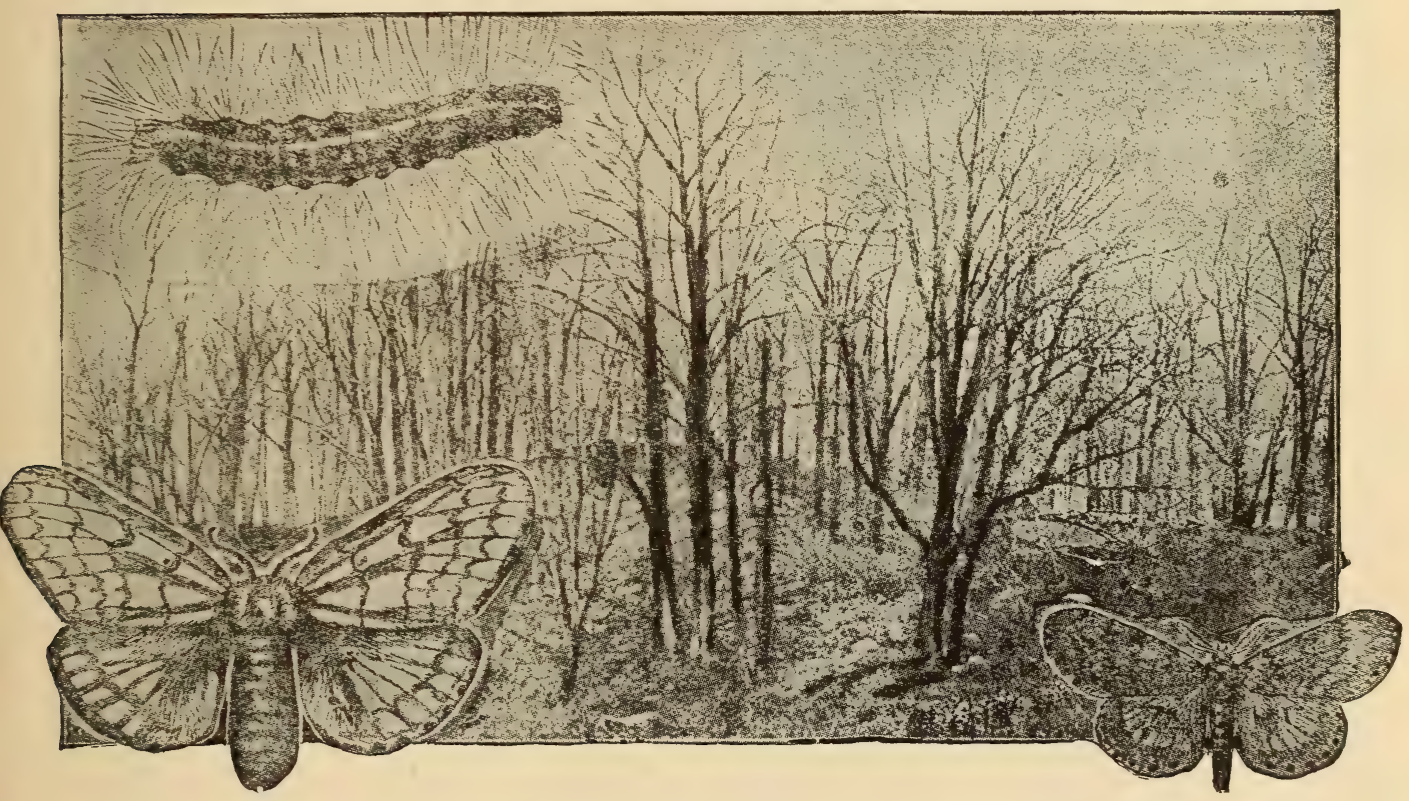

FOREST DEFOLIATED BY GYPSY-MOTH. THE CATERPILLARS EAT THE LEAVES. FEMALE AT LEFT; MALE AT RIGHT.

female gipsy-moths look very different. The eggs are laid in a mass, and the mother moth covers them with hair taken from the back part of her body. She lays from three hundred to five hundred eggs in a season. These moths eat almost all kinds of leaves, and would soon destroy our fruit-trees.

Mother: The caterpillars have big heads and eleven pairs of warts on the back. The first five pairs are blue, and the last six red. Hairs grow out of these warts, which sting the hands worse than nettles. These moths are found in parts of Europe. The brown-tail has white, silky wings, and a brown body. Its caterpillars spin threads and fasten to the tree the 
leaves they are eating. The best time to exterminate these pests is in the winter, and large sums of money are paid to destroy the eggs.

Hazel: Twenty-three gipsy-moth nests were found in one fire-alarm box in Boston, also cast-off skins of caterpillars, and

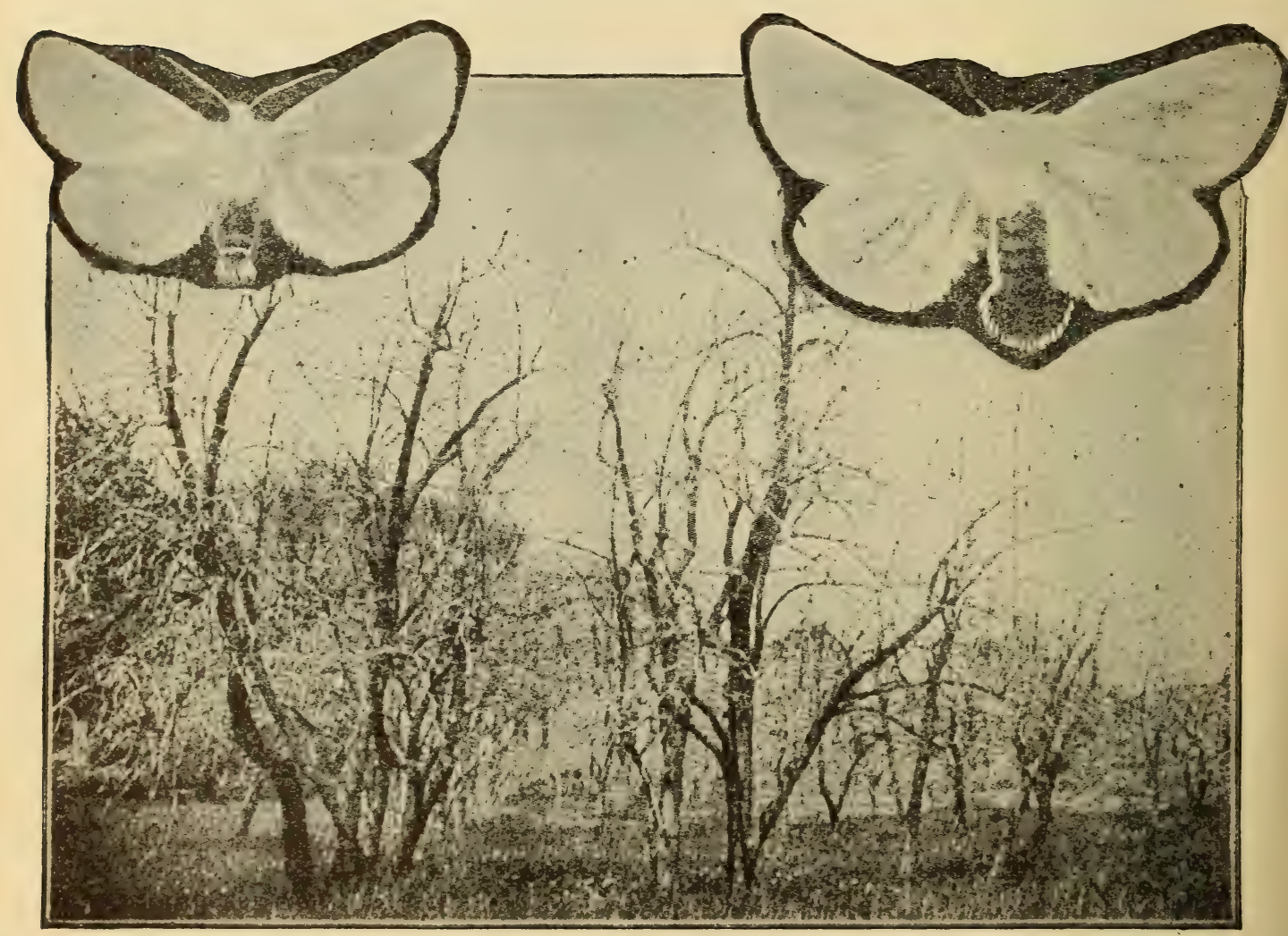

PEAR ORCHARD DEFOLIATED BY BROWN-TAIL MOTH. MALE ON THE LEFT; FEMALE ON THE RIGHT.

pupa-cases. The caterpillars had crawled through the keyhole. So all the boxes were closely examined.

Harold: I read that the Mediterranean moth closed up two of the great flour-mills in Minneapolis, Minnesota. The moths gathered under the fine silk through which the flour is 
sifted, and made webs from one to four inches thick. They also ate holes in the silk, so the flour could not be sifted.

Glenn: I saw what looked like a thick spider-web stretched over the branch on a tree top, and there were a lot of caterpillars inside. What kind were they?

Mother: Web-worms, though they were not worms at all, but tent-caterpillars. They are hatched from a nest of golden eggs laid by the mother moth on a fresh green leaf. They all come from the eggs about the same time, and after eating a breakfast of green leaves, begin to spin. Each one spins a little piece of one big web, and they join their work together so nicely you would not know but one caterpillar had woven it all. The web makes a fine tent. It can be seen best in the morning before the dew is gone. It looks like a lace veil spread over the twigs and leaves. The whole caterpillar family live inside.

Iva: Do they stay under their tent all the time?

Mother: Yes, this kind do not even go out to get their food. They eat the leaves covered with their web. When the supply is gone, they begin to spin lines to other twigs some distance away. They do this so they can find their way back to the tent when they have finished eating. Other kinds make their tent larger, so it will cover more leaves. They are very untidy housekeepers, leaving all kinds of dirt and rubbish about, and throwing their old clothes down where they take them off; for they change their skins like other caterpillars.

Hazel: What do tent-caterpillars look like?

Mother: They have black heads; their bodies are pale green, dotted with black, and long hairs grow out of their backs. Sometimes, when they can cover no more leaves under their tent, they go to a new feeding-ground. They generally move in the night, and quickly weave a new web. These webs are so strong that they protect them from birds and other enemies. 
Iva: How long do the caterpillars stay in their webs? Mother: About a month; then they roll up in a little ball and drop to the ground, where they hide under a stick or stone or some other object, and soon turn to pupæ. They afterward come out as white moths, though sometimes they are spotted with black.

Harold: I have seen men fasten a torch to a pole and burn up the webs in apple-trees, and so get rid of the caterpillars.

Hazel: The Bible tells about the canker-worm and the palmer-worm. They are called a great army. Are they caterpillars instead of worms?

Mother: I think so. There is a moth in the United States whose caterpillars are called palmer-worms. They eat the leaves of apple-trees, leaving only a skeleton of each.

Iva: What is the canker-worm like?

Mother: This is a picture of the male moth, and here is his

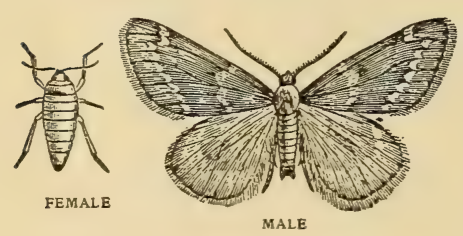

CANKER-WORM MOTHS little mate. She has no wings. She lays her eggs in both fruit- and shadetrees. Here is an
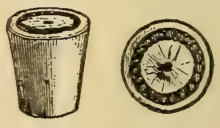

EGG AND TOP OF EGG OF CANKER-WORM enlarged picture of one of these wonderful eggs, and this is the top of one egg. The eggs are laid close together, like honeycomb cells. The larva is a looper; that is, it humps up its body when walking; it can also hold itself out straight like a twig on a branch.

Harold: Are army-worms caterpillars?

Mother: Yes; that name was given them because they march in large numbers at the same time. They generally stay in one place; but when food is scarce, or when there is a dry season, they multiply so that great armies of them march over the country, eating the grass and grain as they go. Once in New England they went up over the houses so close together that 


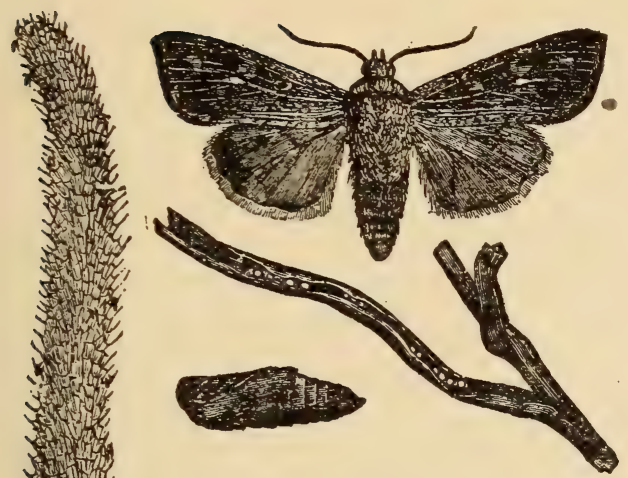

ARMY-WORMS SHOWING FULL-GROWN LARVA, NATURAL SIZE, ALSO ADULT MOTH. ORDINARILY FEED ONLY AT NIGHT, BUT WHEN MIGRATING FEED DAY AND NIGHT.

the boards and shingles could not be seen. They did not eat peas, potatoes, or flax; but wheat and corn were devoured so that only bare stalks were left. Here are pictures of the moth and the caterpillar. When full grown, the caterpillars burý themselves in the ground, and turn to pupæ. The caterpillars called cutworms belong to the same family.

Iva: Please tell us about the clothes-moth, mother. Mother: This is its picture; a small body can do much harm. It belongs to a group called Tin-e-i'na. All the moths in this family are small; when their wings are spread, they will not stretch over half an тне wооLеN-мотн inch. They are pale yellow, and are not pretty. They may be seen flying about in April and May, but keep in shady corners as much as possible. They not only eat woolens and furs, but destroy grain and plants. They lay their eggs in grains of wheat and barley before they are ripe. The caterpillars hatch in a few days, and are hardly as thick as a hair. When grown, they spin cocoons inside the grain, and go to sleep after having made a little round door through which to go out when the grain has been

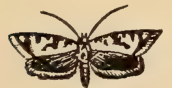

MOTH OF CATERPILLAR THAT EATS GRAIN put in the granary, and they become moths. The grain is useless after the caterpillars have eaten out the

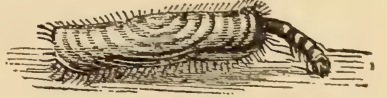

LARVA OF WOOLEN-MOTH 
inside. Moths never eat anything but liquid food. The caterpillar of the wool-moth eats clothing. It is small and white at first, but begins to make its clothes as soon as hatched, and these are the color of the stuff it works in. It makes a tube, or sheath, open at both ends. It puts the bright colors inside, and spins a covering for the outside of whitish silk. The caterpillars put out their heads and look eagerly to right and left for wool that suits them best. Sometimes they draw their bodies half-way out of the sheath in their search. If they can not find what they want, they walk to another place with their six front legs, and hang to their cases, dragging them along with their false legs. When the caterpillars find wool to their liking, they tear it out and put it inside the cases, and still keep busily at work. If one should wish to work at the other end of its case, it turns around inside so quickly that you would suppose it had two heads.

Hazel: Do the caterpillars outgrow their clothes?

Mother: Yes; but as the tube becomes too small, they make it larger by putting a patch in each side of the sheath as neatly as a tailor could mend a coat. It would never do to open the case all the way at once, so they cut a slit half the distance, put in a new piece, then cut the other half open and enlarge that also.

Harold: Do they eat wool for food?

Mother: Yes, as well as for clothing. There is no place they like to work so well as in a chest in some dark room or garret. When the caterpillars are full-grown, they creep into some snug corner, shut up both ends of their tubes, and take a long nap, after which they waken as moths. The caterpillar of the fur-moth does more harm than that of the clothes-moth. It cuts off the hair on furs as closely as it could be done with a sharp razor, and destroys many more hairs than it needs to 
make its sheath. The hair-moth larvæ like to live in the hair with which furniture is stuffed.

Glenn: Do the caterpillars of other moths make tubes to cover their bodies?

Mother: There are quite a number that do. Some caterpillars make their coverings out of bits of sticks, leaves, grass, or straw, stuck together in different ways.

Glenn: Do they walk about?

Mother: Yes, as a snail walks. It looks very odd to see what appears to be a tube walking along without anything in sight to move it. Sometimes these tubes are four or five inches long.

Iva: Do these caterpillars climb trees?

Mother: Yes; and when they wish to close the door, they press the end of the tube against a branch, or they close it by drawing the end together with strong threads. When ready to turn to pupæ, they close both ends, and take a long sleep. Here is a picture of one your Aunt Jennie saw in Australia. She found it one day on a branch, and placed it under a glass. She learned that some of the female insects spend their whole lives in these bags, which sometimes open only at one end. There are cater-

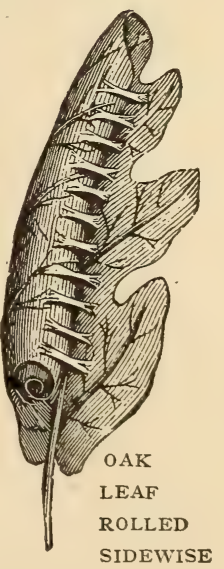
pillars that roll up leaves, and make homes for themselves that way. They spin silk threads, and fasten them to the end of the leaf, and again BAG WORM in its center. Each thread is pulled and made shorter until the edge of the leaf begins to curl up, and then other threads are spun, which in turn are pulled and tightened like the first. 
Over and over and over again the leaf is pulled and rolled, then fastened firmly with short, strong bands of silk, and the home is ready for its tenant, and is full of the food that the caterpillar likes best, - the inside rolls of the leaf. When one roll is eaten, another is made ready. The oak leaf-roller stays in his leafy roll while a chrysalis, and until ready to come out a moth. If the bough is disturbed on which he is feeding, he lets himself down by a silken thread, and may often be seen thus hanging. The moths are a brilliant green.

Glenn: Mother, are there leaf-rollers on maple-trees?

Mother: O, yes! If you leaves are filled with tiny see a little piece of leaf you lift a corner of this would be stuck out, as if

Iva: How large is the

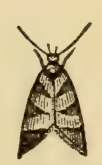

THE LEAFfind a maple-tree whose holes, look sharp until you wrong side up. Should wee tent, a small head to say, "Who's there?" leaf-roller caterpillar?

Mother: Only one sixth of an inch long. It came from an egg left there by its moth mother, who measured less than half an inch across her bluish wings. On her head she wore a little cap of orange-colored feathers. The baby caterpillars become pupæ in their tents, and when the autumn frosts turn the maple leaves to crimson and gold, they float down to earth on the leaves that have been their home. They sleep in snowy blankets during the winter, and become moths in the spring. The caterpillar that rolls basswood leaves cuts the leaf half-way across, rolls it up, and fastens the roll with cords of silk so it can not unfold, and then it lives in the center of the roll, as the caterpillar lives in the oak leaf. This one has a long name, but is commonly known as the basswood leaf-roller. Some caterpillars make tents of leaf-and flower-buds. They tie them tightly with silken threads so they

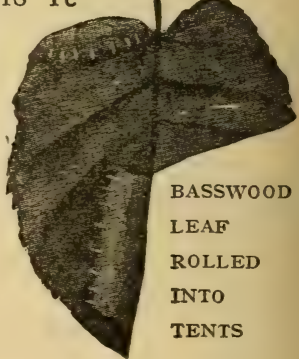


can not open. There is a moth that lives in a tube made of wax. Some moths make the tubes of silk. The mother moth hides about some bcenive during the day, and unless the sentinels keep a sharp lookout, she steals inside just after sunset, in spite of their sharp stings, and lays her eggs in the honeycomb. When they hatch, the caterpillars eat wax, and spin their silk around the honeycomb. Soon the baby bees die.

Harold: Why do not the bees sting the caterpillars, and hustle them out of the hive?

Mother: The caterpillars build tubes in which to live, and the bees can not reach them. These tubes are small at first, but become wider and longer as the caterpillars grow. They are from three to five inches long when the larvæ are grown. When ready to become a chrysalis, the caterpillar makes a cocoon inside its wax tube, and there becomes a moth. There are several kinds of honey-moths.

Hazel: Do moths lay eggs in the fruit as well as in the leaves?

Mother: They like fruit as well as we do. What are called worms in apples are caterpillars of the codling-moth. They have sixteen legs. They become full-grown about the time the apples ripen, or just before, and hide in the fruit-room or in the apple-trees, where they sleep without eating for several months. The moths appear in June or July. In Tasmania the laws are strict against the codling-moth. One man was fined because a dead moth was found in one of his empty fruit-cases. Caterpillars eat vegetables and grain. They are found in fields, forests, and gardens. They work in the night. There are eight hundred different kinds of night-moths. Their proper name is Noc-tur'na, which means night. These moths are scaly, but their caterpillars are smooth. Some feed on leaves, others on roots, and some eat other caterpillars. The cater- 


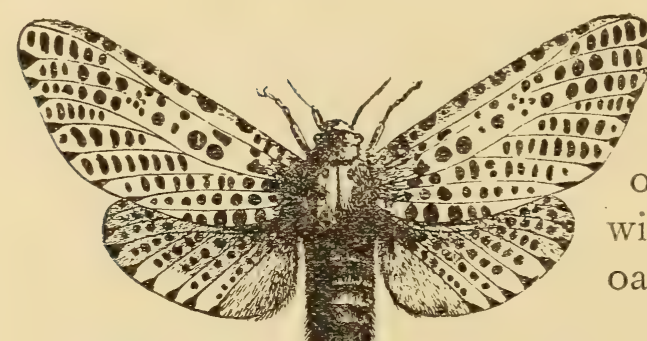

pillar of the goat-moth comes from an egg laid in a crevice in the bark of a tree. It prefers the willow, but will thrive in the oak, elm, and others.

Iva: Does the goat-moth

LEOPARD-MOTH

Mother:

a tiny hole, but

bore galleries in the wood?

Yes, and eats it, too. At first it makes as its body grows, it makes wider passages through which to travel. This weakens the tree; so when strong winds blow, it may fall with a crash. The caterpillar lives from two to four years before it changes to pupa. When disturbed, these larvæ squirt out of their mouths a liquid which has a bad, strong smell. They grow large, sometimes three and one-half inches long and two inches around, and are wonderfully strong. A goat-moth caterpillar was shut up in a glass dome that weighed half a pound, and a book weighing four pounds was placed on top of the glass, but he made his escape. Professor Lyonnet declared more than a hundred years ago that a goat-moth caterpillar has more than four thousand muscles.

Harold: And we have only about five hundred of them.

Hazel: I read that a goatmoth caterpillar was placed in a deep glass, and its captor thought it would be impossible for it to climb up its straight, smooth sides, but it spun stairs from the bottom to the top of the glass dish, and climbed out.

Mother: After living a long time as a caterpillar, the goat

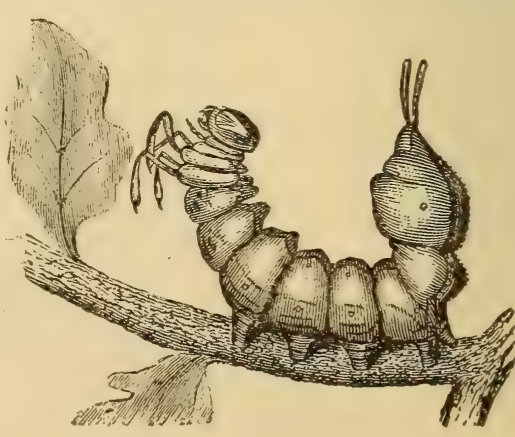

LARVA OF THE LOBSTER-MOTH 
moth builds an egg-shaped cell of sawdust and glue in the wood, and lines it with silk. It makes a good road from this place to the outer bark of the tree. Then it goes to sleep. Before leaving the pupa-case, it crawls to the opening in the bark by means of hooks, or teeth, by which it can push itself along. When it reaches the door, it leaves its pupa-case behind, and crawls out through the bark. Its color is so like that of the tree that it can scarcely be seen.

Iva: Does this pretty spotted moth live in trees, too?

Mother: Its name is the leopard-moth, or wood-leopard, because it is spotted like the leopard. Its larvæ live in trees, such as the elm, pear, and chestnut. This moth caterpillar is the one from which the lobster-moth comes. Its hind legs are forked, and keep moving about to frighten away any insect that might lay eggs on it.

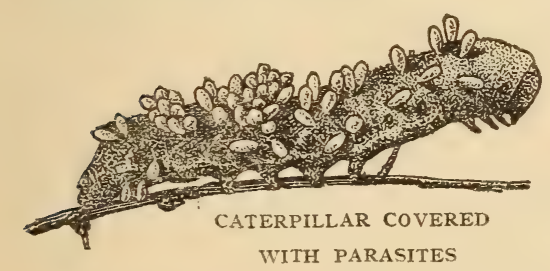

WITH PARASITES Its body is some like that of the lobster. It feeds on beech-trees. Its long front legs look like those of a spider, and it can make itself appear quite like a spider. When full grown, it fastens several puss-мотн leaves together, and there turns to pupa.

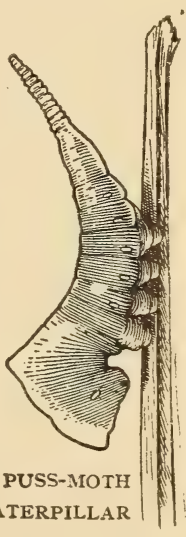

Hazel: What can this rather odd-looking creature be?

Mother: The puss-moth. It can look as fierce as a lion if a bold ichneumon looking for a nesting-place comes near. It does not care to furnish a boarding-place for baby ichneumons. This moth is soft and furry like pussy.

Glenn: What is the matter with this caterpillar?

Mother: It is covered with parasites, which have eaten out the inside of its body. They have now come out of their pupacases, and will soon fly away, leaving the miserable caterpillar with whom they have been living, to die. 


\section{THE SPHINX-MOTHS}

Mother: There is still another family, called the sphinxmoths. Their caterpillars raise the fore part of the body, and keep perfectly still for a long time, and this gives them the likeness to the sphinx in on the hinder part of at night, but the They have the longof the Lep-i-dop'-

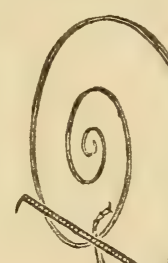
Egypt. They have a horn the body. Most moths fly sphinxes fly in the daytime.

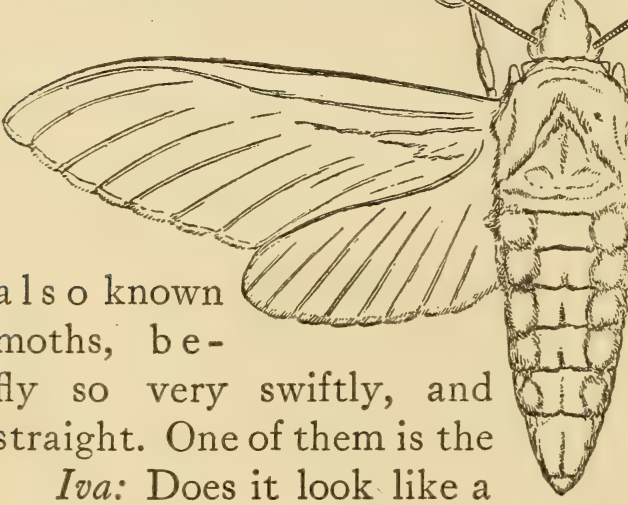

Mother: Ve ry much, Five-Spotted so brilliant. It flies quickly ${ }_{\text {HAWK-MOTH }}$ balancing on its wings est tongues of any te-ra. They are dipping its long trunk into the blossoms for honey. Children call them bird flies; they have a tuft of hairs at the end of the body which looks a little like a bird's tail. They move

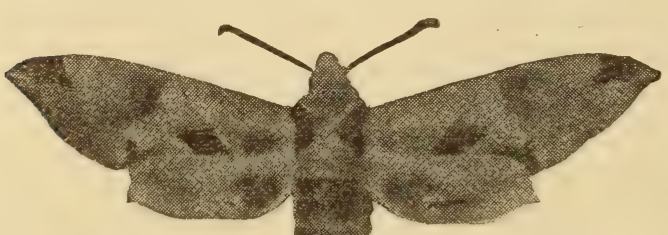
so swiftly that they look like a misty cloud. Though they fly away if you lift your finger, they come back; for they seem to understand beyond danger. that their swift wings can bear them Here is the picture of another hawk- 
moth. It lives on potato-vines, tomato leaves, or tobacco. It is one of the sphinxes, and all their larvæ rear their heads,

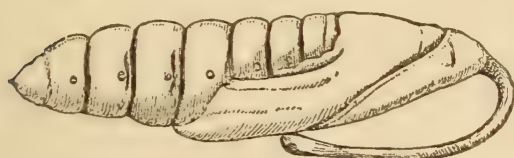

CHRYSALIS OF FIVE-SPOTTED SPHINX and have tails like horns.

Hazel: What a strange pupacase! It looks like a jug with a big handle.

Mother: That is where the trunk of the moth is folded away. When fully grown this sucking-tube will be three or four inches long. The insect can coil it tightly, or bend it forward to suck honey from the flowers. At twilight the moth goes to seek food and to lay its eggs on the leaves of tomato- or potatoplants. Its caterpillar is often called a potato-worm. It is light green with white stripes, and when grown is about three inches in length.

Glenn: Is this the caterpillar of another hawk-moth? It seems larger than any of the others. Mother: It is the largest found in Europe, measurOne kind in

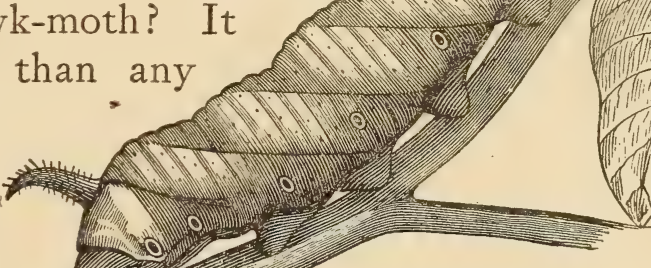
ing four and one-half inches. nine inches long. It is yellow, green, violet, blue, and white, and has many black dots. Unlike most sphinx caterpillars, its horn is rough instead of smooth. It eats potato leaves and other plants. When ready to turn to a chrysalis, it buries itself in the ground, and turns a bright-brown color. On the next page is a picture of the moth. It sometimes measures five inches across the wings. It is called the death's-head hawk-moth. 
Hazel: I see what looks like a skull and bones on its back. Mother: Those marks give it its name. It is thickly covered with dark-brown hair; the mark of the skull is pale yellow. It flies only in the early morning or evening, and makes a squeaking noise. Mr. Wood says: "If seized or
alarmed in any way, it produces a sharp, squeak-
ing sound, something like the cry of a mouse. It
was always easy to make my death's-head
moths squeak, nothing more being re-
quired than
MEAD HAwK-
feet. The
crouch as
shiver or
squeak."

Harold: I suppose such a big moth and caterpillar do a great amount of mischief.

Mother: Some small ones do more. Sometimes the moth works its way into beehives, for it likes honey. The bees may

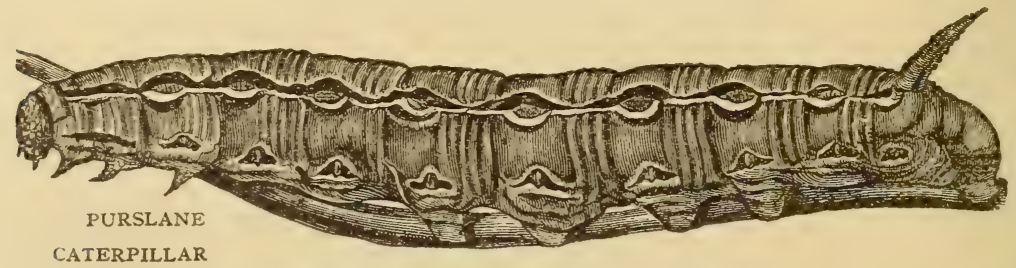

succeed in driving it away with their stings, but its coat of fur is so thick that they often sting to no purfose, and the bees beat a hasty retreat. Here is the purslane caterpillar, another 
of the hawk-moth family. It lives on low-growing plants, such as buckwheat, turnips, and some kinds of weeds. It grows to be four inches long, and is green or brown, with red, yellow, and black spots and lines. The horn near the end of

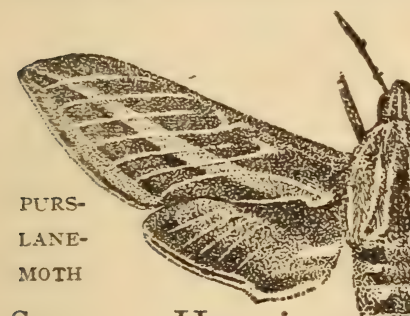

States. Here is a put one of the catseveral inches of which it was feeding. Cover with a piece of glass. After a time you may find the caterpillar gone,but do not worry. In a few days empty the earth out of the pot carefully, and find the chrysalis. Place it back in the soil, keep it damp, but not wet, and still keep the dish covered, so the moth will not escape.

Hazel: How long will it take for it to become a moth?

Mother: About two weeks. You might put a small stick in the flower-pot, on which the moth can rest and dry its wings when it comes out.

- Mother: There is a big moth seen near groves or forests in early summer. stretch over six inches. They

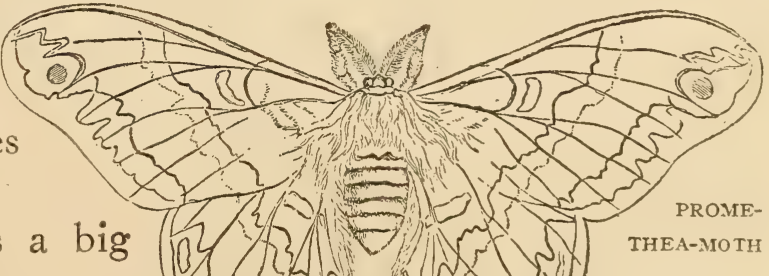
in Ohio, Illinois, Missouri, and other Central s picture of the moth. You can erpillars in an earthen flower-pot with loose soil, and some of the plant on its body is like that of other hawk-moth caterpillars. It is found (n) 
three inches long. It spins a large cocoon, and fastens it to a stem or twig, where it turns to a chrysalis.

Hazel: What kind of moth is this?

Mother: The pro-me'the-a, a beautiful moth whose brown wings have a gray border and are marked with wavy red and white lines. Its horns, or antennæ, look like ferns. Here are pictures of different forms of antennæ. Those that have knobs

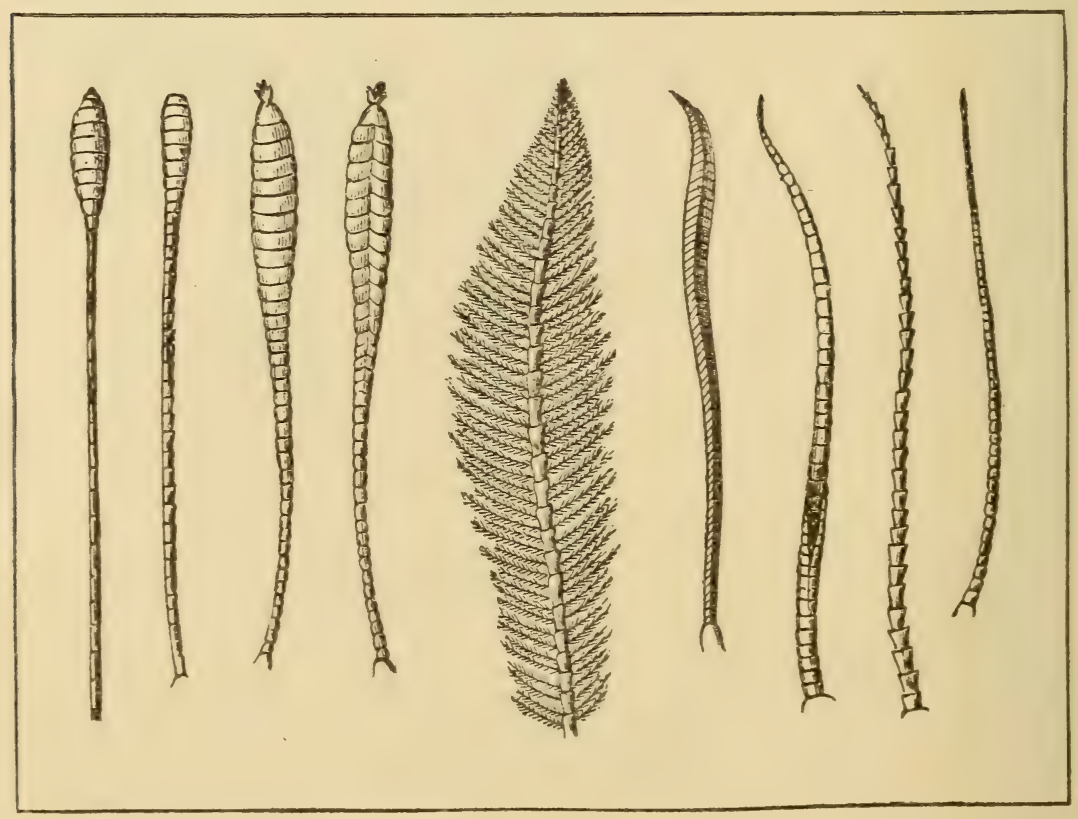

ANTEX̃ OF LEPIDOPTERA

on the end belong to the butterflies, and the others to moths. Promethea's caterpillar fastens a leaf to the twig to cover its cocoon. There it swings in the open air all winter. Should you find one and keep it till summer, if it had no mishap, you would see a beautiful moth.

Hazel: I saw a little blue-and-white insect on a peach-tree. I could not tell whether it was a moth or a wasp. 
Mother: It must have been the peach-borer, which belongs

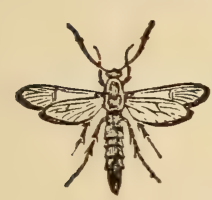

PEACH-BORER to a family called clearwings, because their wings are not covered with hair, or scales, like those of other moths. While a caterpillar, it lives about a year in the wood of peach-trees. It hurts the tree so it can not bear fruit, and sometimes it dies. Harold: Are there many kinds of clearwings?

Mother: Quite a number. Currant clearwings are found on currant bushes, and looks like gnats. Some look like ants, flies, or wasps. The hornet clearwing seems so much like a wasp that it is difficult to tell to what family it belongs. There is one that even looks like the ichneumon-fly, the enemy of all butterflies and moths.

\section{THE MARCHING CATERPILLARS}

Mother: These caterpillars belong to the small gray processionary moth, and live in oaktrees. About sunset they come out and march. Réaumur took an oak branch covered with the m into $h$ is study, and watched them many days. He hung the branch against a window - shutter. When the leaves were dried up, the caterpillars

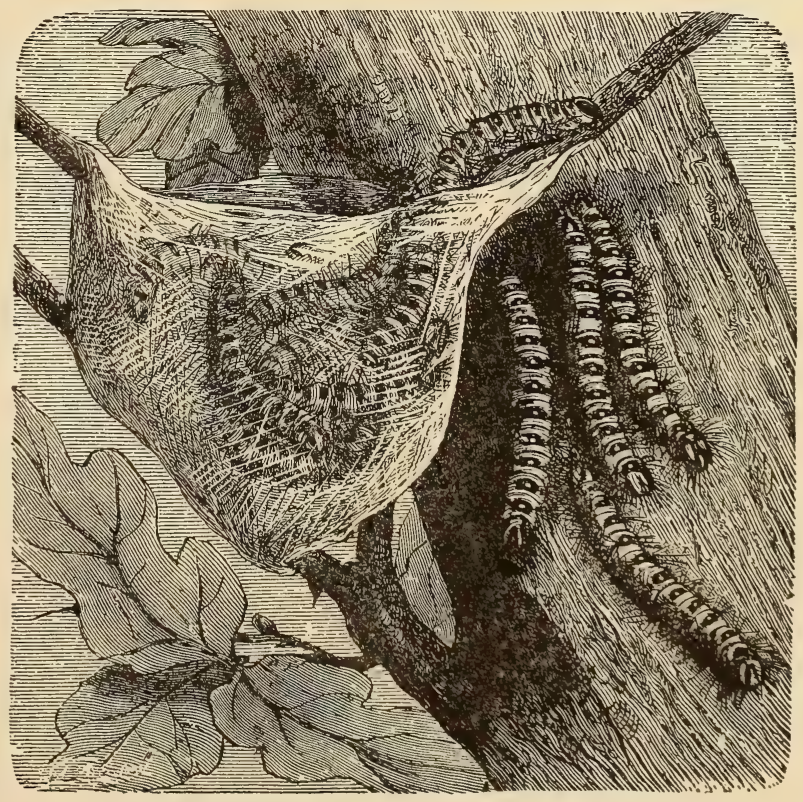

LARVAE OF PROCESSIONARY MOTH 
tried to leave the branch, in order to seek better food. One set himself in motion, a second followed at his tail, a third followed this one, and so on. They began to march up the shutter, so near to each other that the head of the second touched the tail of the first, forming a perfect string of caterpillars about two feet long. Then two caterpillars marched abreast, but as near the one which preceded them as those who were marching in single file were to one another. After a

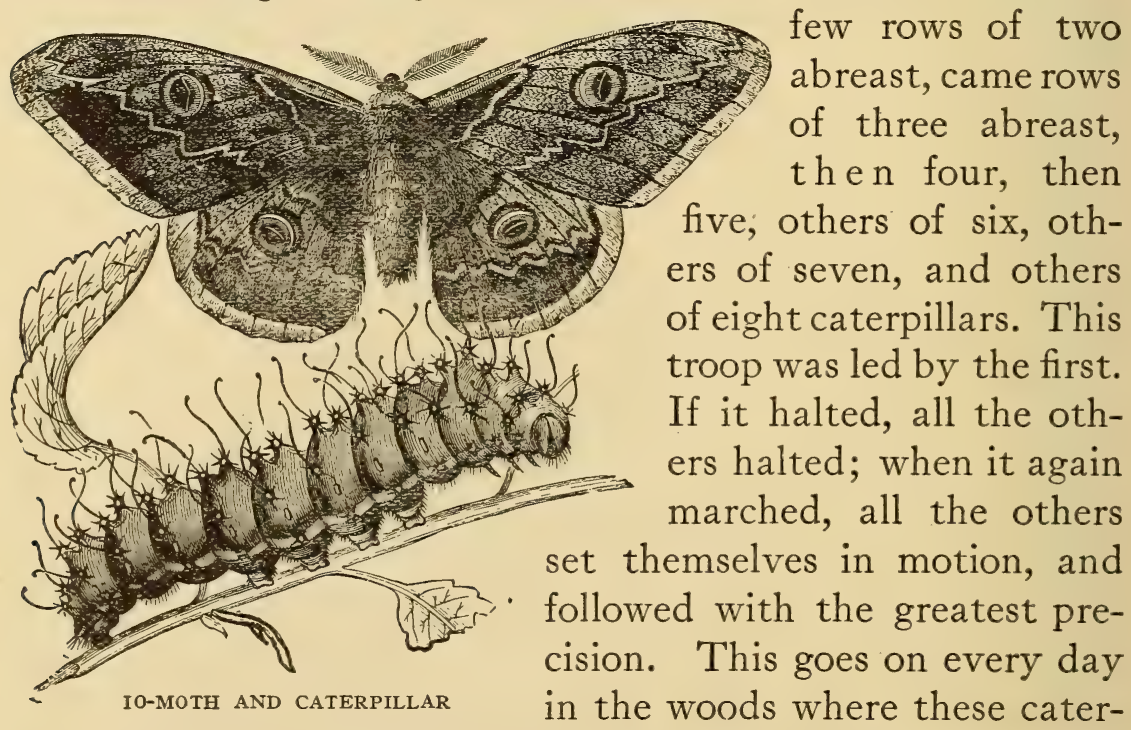
pillars live. When near sunset, one caterpillar comes out of a nest by the opening at the top, which would hardly afford space for two to come out abreast. It is followed by many others in single file. When about two feet from the nest, it pauses, and those still in the nest continue to come out. They fall into their ranks, the battalion is formed, and the leader marches again, all the others following him. That which goes on in this nest takes place in all the neighboring nests at the same time.

Harold: A man once thought he would see how long these 
processionaries would march in one direction, and so started the file on the edge of a large stone vase. For seven long days they traveled on, until every one died. Day and night they followed one another without rest until the end came.

Mother: Here is a picture of the largest moth found in Europe, the Io-moth. When flying at night, it might be taken for a bird. There are spots of one color within a ring of another color on its wings, like the spots, or eyes, at the end of peacocks' feathers. Perhaps they are wing windows. The family of Io-moths is very large in North America, and they all have these color eyes on their wings.

Iva: The caterpillar looks as if it had stars on its back.

Mother: Those stars are stiff, bristling hairs that grow on warty, blue bunches on its body. The caterpillar itself is green. If touched, the hairs sting like nettles. Io caterpillars often march like processionary caterpillars. When walking, they sometimes stretch out in two lines like a $\mathrm{V}$, the way wild geese fly; but when about half-grown, Io caterpillars stop marching together, and each one goes by itself.

\section{Appearances Are Deceitful}

"What a beautiful light that lamp gives," said a moth as he stood on the window-sill.

"Yes, it does," said a fly, who fluttered with great difficulty toward the moth. "But you would better not go near it; it's anything but safe."

"Surely there can be no danger there," said the moth; "the flame looks so cheerful and bright."

"Yes, but it burns," said the fly. "I am suffering from it now. I ventured too near, and it so scorched my wing that it is almost helpless."

"I really think you must be mistaken," answered the moth. 
"I do not see how that beautiful light could injure anything. I shall fly to it, and see for myself."

"Take care," buzzed the fly; "appearances are sometimes deceitful."

"All right," said the moth. He flew toward the flame, and soon fell on the table, severely burned, and nearly dead.

"There is folly now," said the fly. "Some people will trust appearances rather than heed the kind warnings of those who have suffered through their deceitfulness."

The brilliant saloon deceives and destroys boys and men, as the dazzling light scorches the fluttering wings that venture too near. The first cigarette burns the soul; and the boy who is deceived by it and by the first glass of beer, is like the silly moth. - Selected.

\section{Caterpillars and Silk}

Mother: As I was going up-stairs one morning, in Washington, D. C., I saw this moth hiding in a shaded corner. It was pale green, and had tails on its wings like some butterflies; and it had an eye-spot on each of its four wings, surrounded by rings of white, red, yellow, and black. In each eye was a moon. It was the luna-moth, often called the queen of the night, or the pale empress of the night, and it is rarely seen. Its wings cover four or five

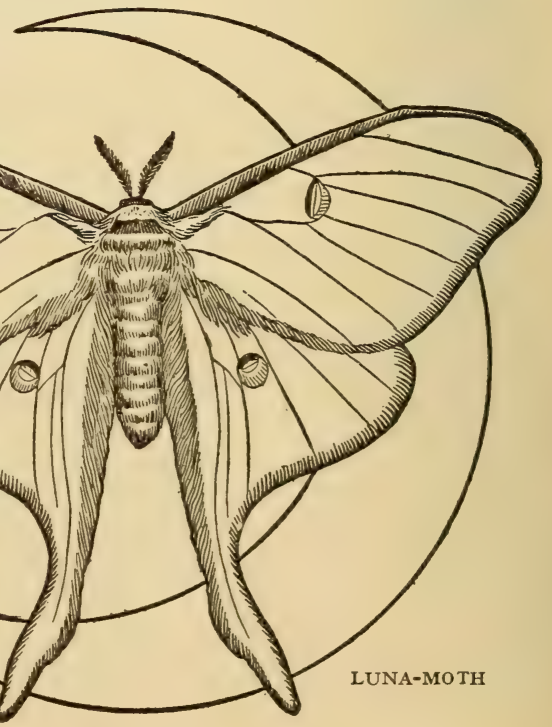


inches. The caterpillar is bluish-green, with yellow bands and stripes. It grows to be about three inches long. When ready to turn to a chrysalis, it draws two or three leaves together, and spins its cozy bed inside them. It afterward falls to the ground, where it remains during the winter. The moth comes out in May or June, and is very pretty. It has some large cousins in other countries, the atlas-moth, in Asia, measuring about nine inches across its wings. I saw one in the Smithsonian Institution in Washington. Giant moths in Brazil have wings that stretch a foot from tip to tip. The silkworm-moth belongs to this family. Some caterpillars are worth thousands of dollars; for the silkworm, or caterpillar, spins the silk to make all the dresses and ribbons worn. Its true name is Bom'byx mo'ri.

Harola: Where is the silkworm found?

Mother: Its native country is China. It is said that more than four thousand years ago there was an emperor in China, known as Hoang-ti. That would be two thousand years before Christ came to this world. Hoang-ti wished his wife, Si-ling-chi, to do all she could to make the people happy, and so told her to study the silkworm, and try to use its threads. Si-ling-chi gathered a large number of the insects and fed them herself. She found out how to rear them, how to wind their silk, and how to weave it into fabrics. From China the eggs of the silkworm were carried to Europe, and the people tried to manufacture silk there, but it was hundreds of years before they were successful. Sometimes it sold for its weight in gold. One emperor would not buy his wife a silk garment because it was so expensive.

Hazel: Now almost every one wears something made of it. Mother: It is less than two hundred years since it became common. Now the rearing of silkworms has become a great industry in many countries, and thousands of men 
and women devote all their time to caring for the caterpillars and making the silk ready for weaving. To France alone over nine million pounds sterling, or about forty-five million dollars, is paid for silk stuffs. You see it pays to care for these caterpillars and set them to work. The first silkfactory in the United States was built at Mansfield, Connecticut, in I8Io. In 1875 the value of silk manufactures in this country had become twenty-seven million dollars a year, and it is much larger now. In Italy, Spain, Greece, and other southern countries of Europe, and in India and China, silk culture is a profitable industry. Here are pictures of the

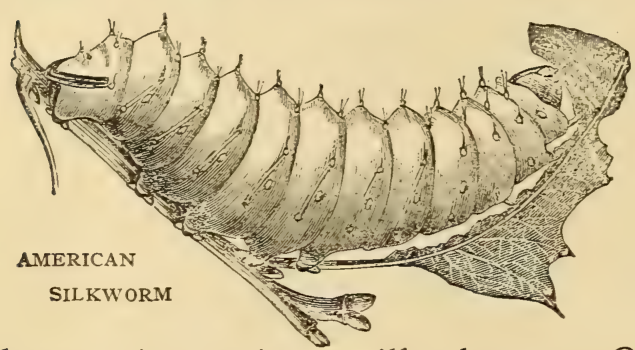
American silkworm caterpillar, its cocoon, and the full-grown moth. The caterpillar is pale green, with yellow lines on its sides.

Iva: What does it eat? Mother: It likes oak leaves best, but will also eat Osage orange, elm, maple, willow, poplar, and other leaves. It has a good appetite; by the time it is grown, one caterpillar will have eaten one hundred twenty oak leaves.

Hazel: It would take quite a forest to keep many of them at that rate. Its cocoon looks as if made of leaves.

Mother: It first spins threads to fasten several leaves together. Then it begins to spin threads between

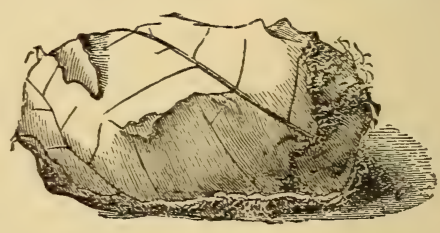
them in all directions, and inside it cocoon of AMERICAN SILKWorm makes its cocoon of many layers of silk, which it sticks together with a kind of glue.

Iva: How long does it take to spin the cocoon?

Mother: About four or five days. The caterpillar then 
turns to a chrysalis, and remains so all winter. You might keep it frozen as hard as stone, and yet in the spring it would come out a large, beautiful moth. It has four eye-spots on its

AMERICAN SILKWORM-MOTH, OR POLYPHEMUS Mотн

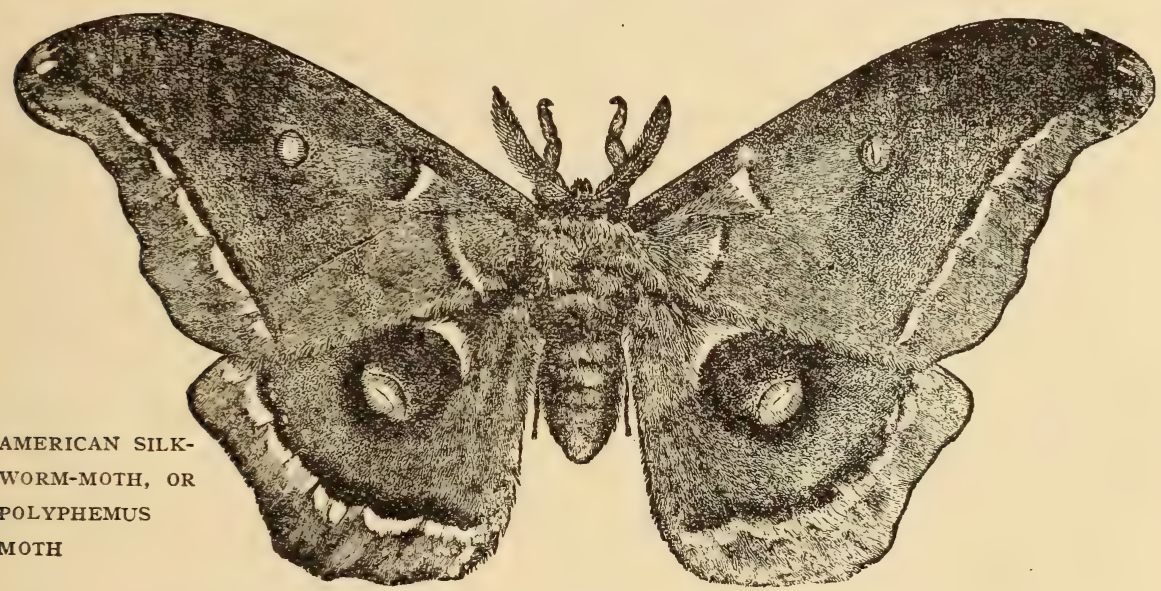

wings, two big ones and two little ones, and looks a little like the luna-moth, but has no tails.

Glenn: How are the moths cared for when they are kept to make silk?

Mother: The first thing is to get the eggs, and to provide a building where the silkworms may be kept, one where the rooms can be kept warm, and supplied with fresh air. There should be plenty of racks, cupboards, or tables that can be easily reached, where the worms may be kept after hatching. Each rack should have a small border, so the silkworms can not fall off.

Harold: Where are the eggs obtained?

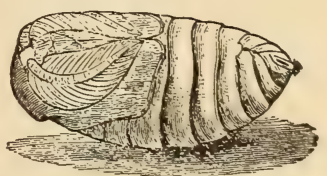

CHRYSALIS OF AMERICAN SILKWORM AFTER COCOON IS TAKEN OFF They are bought in winter, and kept in a cold place. As soon as the buds of the mulberry-trees begin to open, the eggs are set for hatching. Mulberry leaves are the best food, and before beginning to rear the caterpillars, there must be a good supply of leaves. 
Harold: How do the eggs of the silkworm-moth look?

Mother: They are about as large as a pin-head or a mustardseed. When wanted for hatching, they are spread on sheets of clean paper placed on racks. They must not be put in the sunshine, nor left where they will become chilled. In five or six days a few caterpillars come from the eggs; in two or three days more, they begin to come out in large numbers. Those that hatch each day are kept by themselves. Those that come from the eggs after the third day of hatching are generally thrown away. Then the leaves are picked and cut fine. The little caterpillars are covered with netting, and the leaves spread on top of that. They reach through the holes in the net, and are soon eating with all their might.

Glenn: Do they grow fast?

Mother: Indeed they do, but it requires much work and constant care to keep them in health and growing as they should.

Harold: Do they change their skin as other caterpillars do?

Mother: In the same way. This change is called molting, or sickness. They molt four times, so each caterpillar that becomes full-grown passes through five periods of growth, called ages. When ready to molt, the silkworm changes its color from white or gray to yellow. It stops eating, and after spinning a few loose threads, slips under them and goes to sleep, and sleeps from twelve to twenty-four hours. While sleeping, a new skin grows; and when the worm awakes, it begins to twist its head about, causing the old skin to break; so it soon crawls forth in its new suit. After resting about an hour, it is ready to begin eating again. Netting with larger holes is placed over them each time they molt, fresh leaves are placed on top, the worms crawl through, and then all the old litter and skins are cleaned away.

Hazel: Do silkworms eat as much as other caterpillars? 
Mother: Yes, they are as hungry and eat as greedily. Where there are a large number together, it is said the noise made by their jaws when they are eating is like that made by a heavy shower of rain. After molting the last time, they eat without stopping. It takes constant care and attention to rear such a family. At first they are given eight meals a day, and the leaves are cut very fine. From the end of the second age they have but four meals, and the leaves are not cut so small, and after the fourth age they are not cut at all. When the caterpillars are getting ready to go to sleep, they are not fed so much. During the third age they often do not have strength to molt, and soon die. But the greatest number that can not molt are found in the fourth age. This is a critical time for the worms, and for those who keep them.

Hazel: How can one tell whether they are sick or well?

Mother: Those that can not molt are larger than the others and look shiny. The keepers take them away from the trays, for they would soon make the air smell badly. Unless they grow to be full size, they do not spin, and all the labor bestowed upon them is lost. During the last sleep the caterpillars seem to suffer great pain, and often appear as if dead. Even though kept dry and clean, there is an unpleasant, sickly smell in the building, and as many as one sixth of the caterpillars die at this time. Sometimes they get rid of their old skins, but do not have enough strength left to eat. Others become fat and lazy from overeating, and they die, too. Then there are diseases common to silkworms. They seem to become ill in a moment, change to a dull white, and soon die, and after death are covered with a floury dust. Another sickness is present from the beginning of life, becoming worse during each age. Nothing can be done to prevent these diseases except to keep the litter clean on which they feed, the air pure, and not to crowd them too closely together. 
Glenn: When do they spin their silk?

Mother: At the end of the fifth age. During the time they are growing so fast, they must be moved apart every day or two. When grown, they are pale green or a dusty-white color, and have black heads. They grow to be about three inches long. The time from hatching till spinning is a little less than six weeks.

Iva: How do they begin to spin?

Mother: They stop eating, grow very restless, and keep moving their heads about as if looking for something. This is what is callecl the mounting season. The one in charge of the caterpillars then places little dry branches, a wooden frame, a rolled paper, or something hollow, into which the worms can climb to do their spinning.

Harold: Why do they climb up before they make their cocoons?

Mother: No doubt they want something to which they can fasten the house in which they expect to go to sleep. All the caterpillars mount in one day, and are then ready to set their little spinning-machines in motion. The silk is formed in long tubes inside the body of each caterpillar. It comes out of a little opening just back of the mouth. Two streams or threads come out of the tubes at the same time; for it is really a double tube. A sort of varnish is poured over them, which unites them in one, and it is this that makes the shine that we see on silk. Though men have tried to make silk like it, they have failed every time. Caterpillars make the richest, most beautiful fabric known.

Glenn: I should think the silk would get tangled up.

Mother: While inside the body, it is a thick fluid, which becomes hard as soon as poured out through the spinneret of the caterpillar. The first threads are coarse, and are fastened to the branches as a framework to hold the finished cocoon in 
place. This is called floss, or refuse silk. The caterpillar moves its head every time it spins a thread, and moves it very quickly, too; it is no drone while at work. Back and forth goes the little black head, spinning a thread laid in loops like the figure 8. It is said that it moves its head about three hundred thousand times in making its cocoon. As it takes three days, or seventy-two hours, to finish it, you can see how fast it must work.

Harold: That would make one hundred thousand movements a day, four thousand one hundred sixty-six an hour, or sixty-nine every minute, more than one a second.

Glenn: How long is the thread it spins?

Mother: It makes one about an inch long with every movement, so. the whole thread is more than half a mile long, and some say much longer. While spinning, the silkworm curls itself up like a horseshoe with its legs outside, and places the thread all around its body. At first, while the threads are still soft, it can be seen at work. It glues the threads together as it spins, and when its work is finished, it has a snug home where it can lie safely hidden while in the pupa state.

Harold: How does it look while asleep?

Mother: It becomes much smaller than when it began spinning; for all the silk of which its cocoon is made was inside its body. It turns as white as wax, its false legs wither away, the skin dries up, and the pupa pushes it back to the hinder part of the cocoon.

Hazel: How long does it stay inside?

Mother: From fifteen to seventeen days. Here is a picture

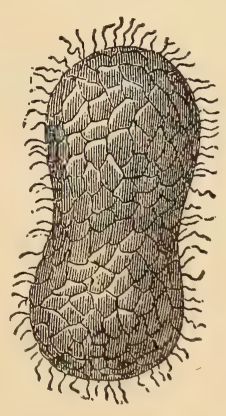

COCOONS OF SILKWORMS

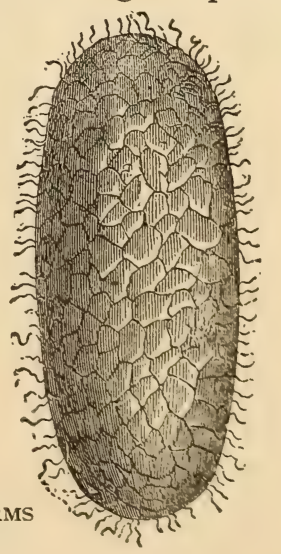


of two cocoons. Most cocoons are white or yellow. The white ones are made of the choicest silk. Some are green, rose-colored, or even purple.

Hazel: How can one know when the spinning stops?

Mother: When there is no noise inside, the work is done. The cocoons are gathered together and sorted, and some are kept for moths to lay eggs for the next hatching. 'The female cocoon is larger than that of the male.

Glenn: How can it ever get out of its prison?

Mother: I do not wonder that you ask; for, while one thread of silk is not very strong, when thousands are woven together, they would bind the strongest giant. One thing that helps the chrysalis is that there is a liquid in its body with which it moistens the silk, and then it makes its way out, and becomes a moth if left to itself. But to get the silk, the cocoons are steamed or baked, and that kills the chrysalises inside. Some stick the cocoons they wish to save close together on brown paper. As soon as the moths appear, they are put on cloth or shects of paper, where they lay their eggs.

Iva: Do they ever fly away?

Mother: The females of moths reared for silk-spinning have imperfect wings, and even in the wild state stay in their own mulberry-tree all their lives. Their willingness to stay at home makes them of value; for if they were disposed to roam about, it would be impossible to produce silk. There is a moth in Brazil that makes even better silk than the one of which you have been reading, but it can not be kept quiet. You see workers who remain at home accomplish most in the world. The mother moth is very orderly about laying her eggs. She places them side by side, but rarely piles them up. The eggs are covered with glue, which sticks them to the cloth or paper on which they are laid, and they can be rolled up and stored in a cold room until the following spring. 
Hazel: How many eggs does each moth lay?

Mother: From three hundred to seven hundred. They are bright yellow at first, then brown, gray, blue, violet, and yellow again. It takes about thirty-five thousand eggs to weigh an ounce.

Harold: How is the silk got off the cocoons? I should think it would become so tangled that it could not be unwound.

Mother: It is a hard task, and requires patient, careful, and close attention. First, the flossy covering is picked off, and the cocoons tossed into hot water to loosen the gum that sticks the threads together. While soaking, they are stirred about with a small brush or a branch covered with twigs. The threads that get caught on the brush or in the twigs are shaken about with the hand till they can be joined together and wound on a reel made for the purpose.

Glenn: I should think such slender threads would break.

Mother: They do, and must then be found and joined together. If the silk on one cocoon is not so long as that on others, another is taken to make the thread of the same length. When reeled off, it is called raw silk. Then it is taken to a factory, where it is cleaned, doubled, twisted, dyed, and made ready for the weaver.

Harold: No wonder silk costs more than cotton or wool when it takes so much work and care to prepare it.

Mother: And it is the humble caterpillars that work day and night furnishing these rich and costly fabrics, most beautiful of anything to wear. So while we remember that many insects are troublesome and cause us loss, we must not forget that millions more are a benefit and a blessing to man. 


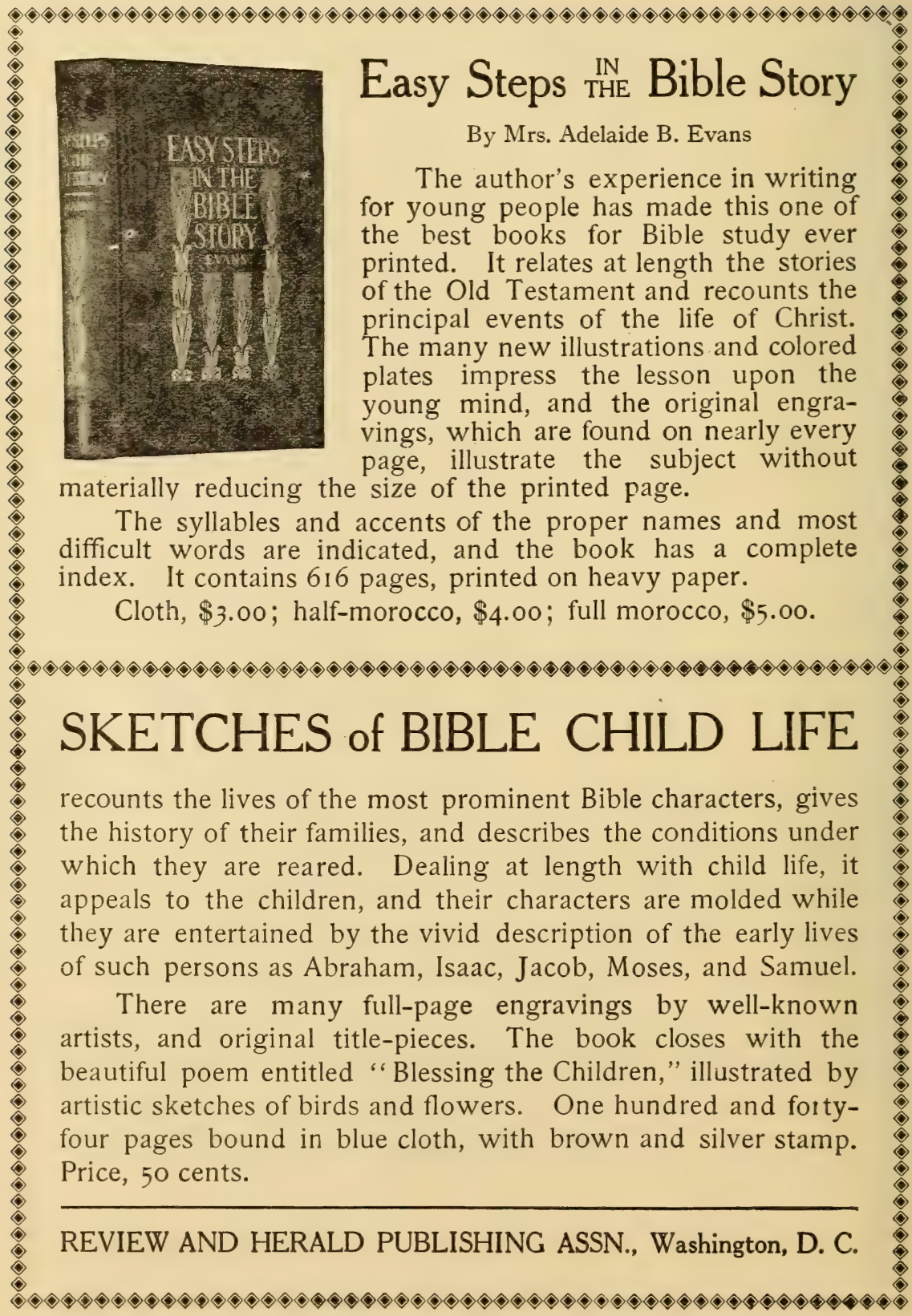


"To train up a child in the way he should go," one must have good books; and to be sure that "he will not depart from it," lessons and examples of Christian lives must be impressed upon his mind. "Best Stories" is just the book to meet this demand. It is printed in two sections and serves a double purpose. The first portion of the book consists of easy lessons in script and print for young children, and is illustrated by threecolor work and pen sketches. The second section is designed for older children, and includes the discussion of important events in Bible history, written in a way to hold the attention of the youth, and a study of many vital topics of present truth, presented in an attractive manner. It consists of about 200 pages, bound as follows:-

Board cover, cloth back, 50 cents; red cloth, embossed, 75 cents.

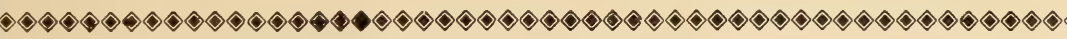
MY GARDEN NEIGHBORS

In this age of books, children will read something; if they are not supplied with instructive literature, they will read whatever books first come to hand. "Garden Neighbors" never fails to interest the young people, and even older persons enjoy the interesting nature stories. It describes the haunts and habits of birds and small animals, and tells in story form many remarkable things about our neighbors of the animal kingdom. It creates a love of nature in the wonderful works of creation, and by teaching observation brings to the attention many interesting things in nature which would otherwise pass unnoticed.

The last twenty-five pages of the book are devoted to outline descriptions of many species of birds, giving their size, color, natural habitat, and peculiarities.

It is well illustrated and is bound in blue, with blue and white cover stamp, containing 250 pages. Price, $\$ 1.00$.

REVIEW AND HERALD PUBLISHING ASSN., Washington, D. C. 


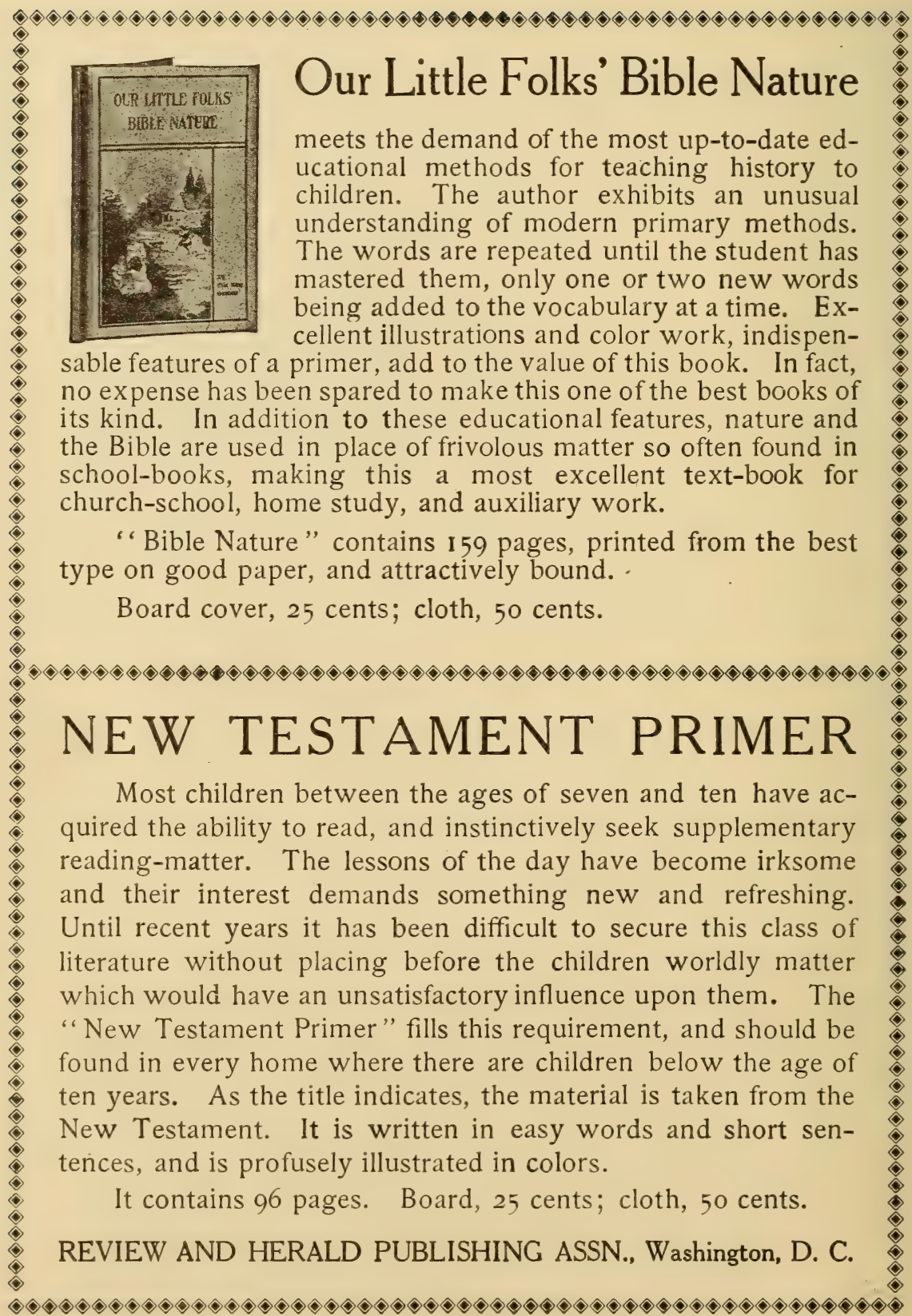



NoV $20 \quad 1913$ 
